ROBERTO RICARDINO

\title{
ADMINISTRAÇÃO DE CONTRATO EM PROJETOS DE CONSTRUÇÃO PESADA NO BRASIL: \\ UM ESTUDO DA INTERFACE COM O PROCESSO DE ANÁLISE DO RISCO
}

\begin{abstract}
Dissertação apresentada à Escola Politécnica da Universidade de São Paulo para obtenção do título de Mestre em Engenharia
\end{abstract}


ROBERTO RICARDINO

\title{
ADMINISTRAÇÃO DE CONTRATO EM PROJETOS DE CONSTRUÇÃO PESADA NO BRASIL: \\ UM ESTUDO DA INTERFACE COM O PROCESSO DE ANÁLISE DO RISCO
}

\author{
Dissertação apresentada à \\ Escola Politécnica da Universidade de \\ São Paulo para obtenção do título de \\ Mestre em Engenharia \\ Área de concentração: \\ Gerenciamento de Empresas e \\ Empreendimentos na Construção Civil \\ Orientador: \\ Prof. Dr. Cláudio Tavares de Alencar
}


Este exemplar foi revisado e alterado em relação à versão original, sob responsabilidade única do autor e com a anuência de seu orientador.

São Paulo, 23 de agosto de 2007.

Assinatura do autor

Assinatura do orientador

Ricardino, Roberto

Administração de contrato em projetos de construção pesada no Brasil: um estudo da interface com o processo de análise do risco / R. Ricardino. -- ed.rev. -- São Paulo, 2007. $172 \mathrm{p}$.

Dissertação (Mestrado) - Escola Politécnica da Universidade de São Paulo. Departamento de Engenharia de Construção Civil.

1.Administração de contrato 2.Planejamento 3.Construção pesada (Projetos) I.Universidade de São Paulo. Escola Politécnica. Departamento de Engenharia de Construção Civil II.t. 
Aos meus pais

Henriqueta e Silvio,

em memória.

À minha esposa

Nanci

e aos nossos filhos:

Juliana,

Mariana e

Renato. 


\section{AGRADECIMENTOS}

Aos professores do Grupo de Estudo e Pesquisa em Real Estate - GEPE-RES, Prof. Dr. João da Rocha Lima Jr., Prof. ${ }^{a}$ Dr. ${ }^{a}$ Eliane Monetti, Prof. Dr. Cláudio Tavares de Alencar e Prof. Dr. Sérgio Alfredo Rosa da Silva, por seu apoio, incentivo e ensinamentos.

Aos meus orientadores, professores Cláudio Tavares de Alencar e Sérgio Alfredo Rosa da Silva, por suas diretivas e contribuições inestimáveis.

Ao Prof. Dr. Hermes Fajersztajn, pelos sólidos aportes ao trabalho, recebidos na Banca de Qualificação.

Ao amigo e jurisconsulto Antônio Carlos Cintra do Amaral, Mestre em Direito, pela preciosa colaboração.

A Antônio Bacelar de Rezende Filho, Carlos Hermanny Filho, Eleuza Terezinha Manzoni dos Santos Lores, Mariana França, Mário Jorge Moreira e Olindina Perez Dominguez, por terem possibilitado a realização dos levantamentos de campo.

À Fátima Regina Gonçalves Sanches Domingues, pela ajuda sempre prestimosa. 


\section{RESUMO}

Tomando por hipótese fatores e habilidades influentes na gestão de projetos e de contratos, esta dissertação tem por objetivo propor um conjunto mínimo de procedimentos que oriente o planejamento da Administração de Contrato, com base no gerenciamento de riscos. Partindo de uma revisão da literatura sobre os processos de administração de contratos e de riscos, o trabalho discute a sua interface e investiga os pontos de vista das partes compradora e vendedora que celebram contratos de obras do setor da construção pesada, aqui representadas por duas organizações com forte presença no mercado brasileiro. Também é apresentado e discutido um método de análise e estruturação de contratos. O trabalho revela os principais requisitos do planejamento da Administração de Contrato.

Palavras-chave: Construção pesada. Contrato. Administração de Contrato. 


\begin{abstract}
Assuming influential factors and skills on project and contract management, the aim of this dissertation is to propose a minimum set of procedures to serve as guidance on Contract Administration planning, based on risk management. Grounded in a review of the literature on contract and risk management processes, this work discusses its interface and examines the viewpoints of the buying and selling parties that sign contracts of projects in the heavy construction industry, herein represented by two companies that play a significant role in the Brazilian market. In addition, a contract analysis and structuring method is presented and discussed. This work shows the main requirements of Contract Administration planning.
\end{abstract}

Keywords: Heavy construction. Contract. Contract Administration. 


\section{LISTA DE FIGURAS}

Figura 1.1 - Etapas básicas do processo de contratação..............................................................

Figura 1.2 - Fluxograma das principais etapas de desenvolvimento do trabalho................ 9

Figura 1.3 - Mapa da disposição de dados dos Estudos de Caso 1 e 2.................................... 12

Figura 2.1 - Formação das peças integrantes do contrato......................................................... 14

Figura 2.2 - Como o contrato pode ser formado ou analisado............................................... 25

Figura 2.3 - $\quad$ O cenário da negociação....................................................................................... 28

Figura 3.1 - Alcance da administração contratual..................................................................... 32

Figura 3.2 - Mapa do processo de alteração do contrato......................................................... 47

Figura 4.1 - Momentos de escolha e aceitação do risco........................................................ 52

Figura 4.2 - Matriz do processo de gerenciamento de riscos................................................... 55

Figura 4.3 - Mapa do planejamento da administração contratual........................................... 60

Figura 5.1 - Experiência profissional dos entrevistados........................................................... 69

Figura 5.2 - Tempo de lotação em canteiros de obras............................................................. 70

Figura 5.3 - Experiência com regimes de execução de contratos............................................. 71

Figura 5.4 - Experiência com mais de um regime de execução de contratos......................... 71

Figura 5.5 - Experiência em Administração de Contrato.......................................................... 72

Figura 5.6 - Meios de aprendizagem em Administração de Contrato...................................... 73 


\section{LISTA DE QUADROS}

Quadro 2.1 - Aspectos do regime de preço global.................................................................. 22

Quadro 2.2 - Aspectos do regime de preço unitário................................................................... 23

Quadro 2.3 - $\quad$ Aspectos do regime de administração.................................................................. 23

Quadro 3.1 - $\quad$ Preceitos de interpretação de contratos.............................................................. 37

Quadro 3.2 - $\quad$ Prós e contras do processo de mediação............................................................. 42

Quadro 3.3 - Prós e contras do processo de arbitragem.......................................................... 43

Quadro 3.4 - Técnicas e habilidades influentes na gestão de Projetos e de contratos....... 48

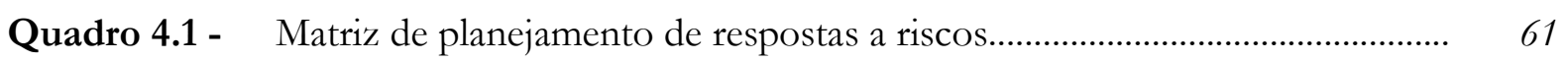

Quadro 5.1 - Conjunto referencial dos Quesitos 7 e 8.............................................................. 64

Quadro 5.2 - Conjunto referencial dos Quesitos 9 e 10............................................................ 65

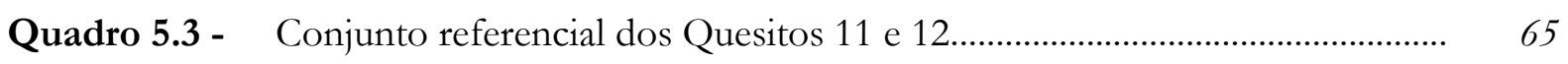

Quadro 5.4 - Conjunto referencial dos Quesitos 13 e 14...................................................... 66

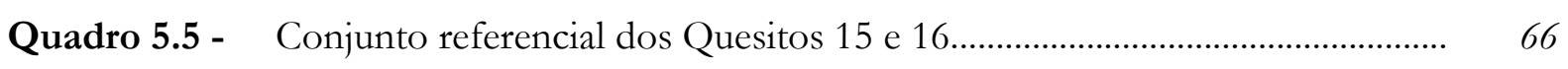

Quadro 5.6 - Aspectos da aplicação do questionário aos Estudos de Caso........................... $\quad 68$

Quadro 6.1 - Fatores críticos à gestão de projetos...................................................................... 86

Quadro 6.2 - Habilidades técnicas críticas à gestão de projetos............................................. 87

Quadro 6.3 - Habilidades pessoais críticas à gestão de projetos............................................. 87

Quadro 6.4 - $\quad$ Requisitos críticos à Administração de Contrato................................................ 87

Quadro 6.5 - $\quad$ Requisitos críticos ao atendimento de reivindicação contratual...................... $\quad 88$

Quadro 6.6 - Cláusulas contratuais que afetam cálculos de danos, do ponto de vista da Contratante........................................................................................... 92

Quadro 6.7 - Cláusulas contratuais que afetam cálculos de danos, do ponto de vista da Contratada................................................................................................ 93

Quadro C.1 - Articulação das Tabelas do APÊNDICE C........................................................ 117

Quadro D.1 - Articulação das Tabelas do APÊNDICE D..................................................... 139 


\section{LISTA DE EQUAÇÕES}

Equação B.1 - Fórmula de cálculo do tamanho da amostra.................................................... 114

Equação D.1 - Cálculo da estatística qui-quadrado................................................................... 138 


\section{LISTA DE TABELAS}

Tabela 2.1 - Classificação das estimativas de custo................................................................... 15

Tabela 5.1 - $\quad$ Estrutura do questionário aplicado aos Estudos de Caso.................................. 63

Tabela 5.2 - $\quad$ Fatores mais influentes no Gerenciamento de Projetos................................. 75

Tabela 5.3 - Fatores mais influentes na Administração de Contrato................................. 78

Tabela 5.4 - Fatores que afetam o atendimento de reivindicação contratual..................... 79

Tabela 5.5 - $\quad$ Habilidades técnicas do Gerente, influentes na gestão de projetos.............. 80

Tabela 5.6 - Habilidades pessoais do Gerente, influentes na gestão de projetos............. $\quad 81$

Tabela 5.7 - $\quad$ Freqüência de respostas à opção “Outros”"...................................................... 82

Tabela 5.8 - $\quad$ Respostas mais freqüente de cada Quesito do questionário........................... 84

Tabela 6.1 - Requisitos mais influentes na prática da Administração de Contrato Ponto de vista da parte Contratante.............................................................. 88

Tabela 6.2 - Requisitos mais influentes na prática da Administração de Contrato Ponto de vista da parte Contratada............................................................. 89

Tabela 6.3 - Fatores que afetam o atendimento de reivindicação contratual - Ponto de vista da parte Contratante...................................................................... 90

Tabela 6.4 - Fatores que afetam o atendimento de reivindicação contratual - Ponto de vista da parte Contratada......................................................................... 90

Tabela B.1 - Matriz da margem de erro amostral dos Estudos de Caso........................... 115

Tabela C.1 - Respostas ao Quesito 1 e posição das suas variáveis....................................... 118

Tabela C.2 - Respostas ao Quesito 2 e posição das suas variáveis...................................... 119

Tabela C.3 - Respostas ao Quesito 3 e posição das suas variáveis......................................... 119

Tabela C.4 - Respostas ao Quesito 4 e posição das suas variáveis....................................... 120

Tabela C.5 - $\quad$ Experiência dos entrevistados em múltiplos regimes de execução.............. 120

Tabela C.6 - $\quad$ Matriz das respostas do Quesito 4 no Estudo de Caso 1............................... 121

Tabela C.7 - $\quad$ Matriz das respostas do Quesito 4 no Estudo de Caso 2............................. 121

Tabela C.8 - Respostas ao Quesito 5 e posição das suas variáveis....................................... 122

Tabela C.9 - Respostas ao Quesito 6 do questionário............................................................ 122

Tabela C.10 - Respostas ao Quesito 7 do questionário............................................................... 123

Tabela C.11 - Respostas ao Quesito 8 do questionário............................................................... 124

Tabela C.12 - Posição das variáveis dos Quesitos 7 e 8...................................................... 125

Tabela C.13 - Respostas ao Quesito 9 do questionário............................................................... 126

Tabela C.14 - Respostas ao Quesito 10 do questionário........................................................... 127

Tabela C.15 - Posição das variáveis dos Quesitos 9 e 10....................................................... 128

Tabela C.16 - Respostas ao Quesito 11 do questionário....................................................... 129 
Tabela C.17 - Respostas ao Quesito 12 do questionário............................................................. 129

Tabela C.18 - Posição das variáveis dos Quesitos 11 e 12...................................................... 130

Tabela C.19 - $\quad$ Respostas ao Quesito 13 do questionário.............................................................. 131

Tabela C.20 - Respostas ao Quesito 14 do questionário.......................................................... 132

Tabela C.21 - Posição das variáveis dos Quesitos 13 e 14...................................................... 133

Tabela C.22 - Respostas ao Quesito 15 do questionário.......................................................... 134

Tabela C.23 - Respostas ao Quesito 16 do questionário......................................................... 135

Tabela C.24 - Posição das variáveis dos Quesitos 15 e 16...................................................... 136

Tabela D.1 - Teste dos dados relativos aos Quesitos 7 e 8 do EC-1 ................................... 140

Tabela D.2 - Teste dos dados relativos aos Quesitos 7 e 8 do EC-2 .................................. 141

Tabela D.3 - Teste dos dados relativos aos Quesitos 9 e 10 do EC-1................................ 142

Tabela D.4 - Teste dos dados relativos aos Quesitos 9 e 10 do EC-2 ................................. 143

Tabela D.5 - Teste dos dados relativos aos Quesitos 11 e 12 do EC-1.............................. 144

Tabela D.6 - Teste dos dados relativos aos Quesitos 11 e 12 do EC-2.............................. 145

Tabela D.7 - Teste dos dados relativos aos Quesitos 13 e 14 do EC-1............................ 146

Tabela D.8 - Teste dos dados relativos aos Quesitos 13 e 14 do EC-2.............................. 147

Tabela D.9 - Teste dos dados relativos aos Quesitos 15 e 16 do EC-1.............................. 148

Tabela D.10 - Teste dos dados relativos aos Quesitos 15 e 16 do EC-2.............................. 149 


\section{LISTA DE ABREVIATURAS E SIGLAS}

$\begin{array}{ll}\text { AAA } & \text { American Arbitration Association } \\ \text { ABNT } & \text { Associação Brasileira de Normas Técnicas } \\ \text { ADR } & \text { Alternative Dispute Resolution } \\ \text { AGC } & \text { Associated General Contractors of América } \\ \text { AIA } & \text { American Institute of Architects } \\ \text { ASCE } & \text { American Society of Civil Engineers } \\ \text { BOT } & \text { Build, Operate, Transfer } \\ \text { CII } & \text { Construction Industry Institute } \\ \text { DRBF } & \text { Dispute Resolution Board Foundation } \\ \text { EC-1 } & \text { Estudo de Caso 1 } \\ \text { EC-2 } & \text { Estudo de Caso 2 } \\ \text { ENAA } & \text { Engineering Advanced Association of Japan } \\ \text { EPC } & \text { Engineering, Procurement, Construction } \\ \text { EPUSP } & \text { Escola Politécnica da Universidade de São Paulo } \\ \text { FIDIC } & \text { Fédération Internationale des Ingénieurs-Conseils } \\ \text { IBRD } & \text { International Bank for Reconstruction and Development } \\ \text { ICE } & \text { Institution of Civil Engineers } \\ \text { JBIC } & \text { Japan Bank for International Cooperation } \\ \text { PMI } & \text { Project Management Institute } \\ \text { TKLS } & \text { Turnkey Lump Sum } \\ & \end{array}$




\section{SUMÁRIO}

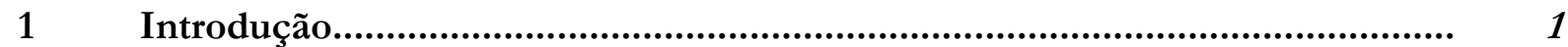

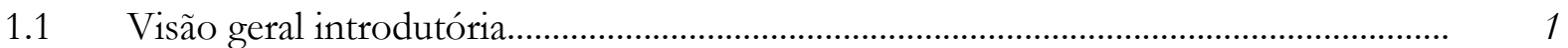

1.2 Relevância do tema abordado......................................................................................

1.3 Objetivos e delimitação da pesquisa...................................................................................

1.4 Método de desenvolvimento da dissertação.......................................................................... 8

1.5 Arranjo do trabalho..................................................................................................... 11

2 Contratos de projetos de construção pesada....................................................... 13

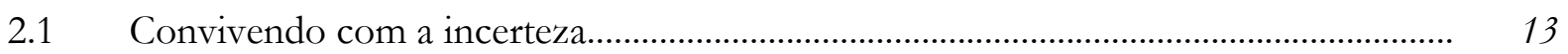

2.2 Características principais de algumas modalidades de contratos..................................... 16

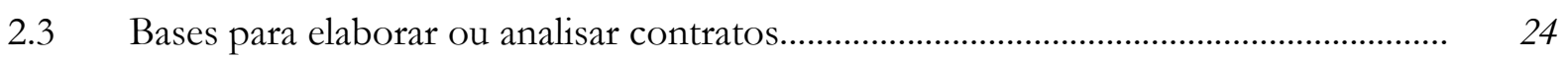

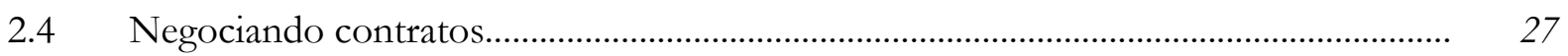

$3 \quad$ Aspectos da Administração de Contrato....................................................... 31

3.1 Princípios da administração contratual........................................................................... 31

3.2 Importância da interpretação do contrato........................................................................ 36

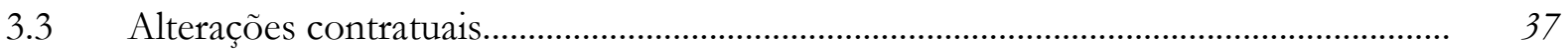

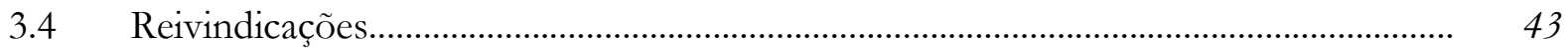

3.5 Técnicas e habilidades influentes na gestão de projetos e de contratos.......................... 47

4 Interface entre os processos de Administração de Contrato e análise do

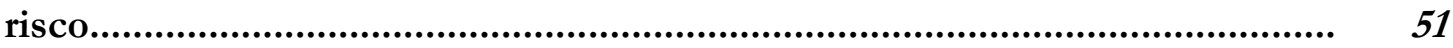

4.1 O risco no contexto do processo de contratação.............................................................. 51

4.2 Princípios do gerenciamento de riscos.............................................................................. 53

4.3 Planejando as respostas a riscos................................................................................... 56

4.4 Surgimento do plano de administração contratual............................................................ 58

$5 \quad$ Apresentação dos Estudos de Caso realizados.............................................. 62

5.1 Considerações sobre o questionário da pesquisa.............................................................. 62

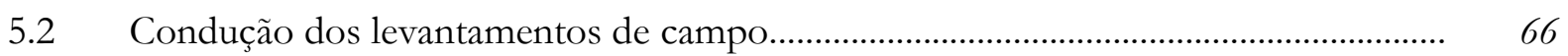

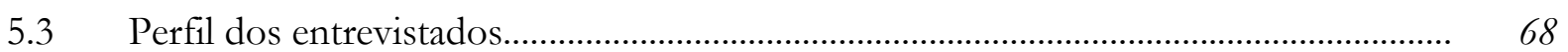

5.4 Resultados dos Estudos de Caso realizados..................................................................... 
6 Requisitos do planejamento da Administração de Contrato.

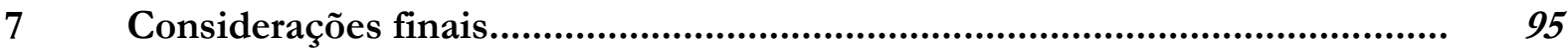

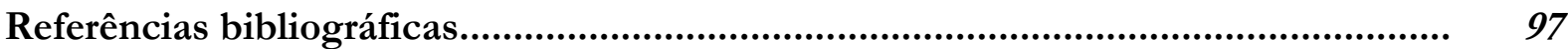

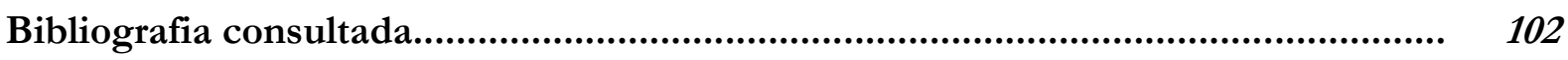

APÊNDICE A - Questionário aplicado aos Estudos de Caso 1 e 2......................... 105

APÊNDICE B - Nível de confiança e margem de erro amostral............................. 113

APÊNDICE C - Tabulação das respostas ao questionário...................................... 116

APÊNDICE D - Teste de significância dos dados obtidos....................................... 137

APÊNDICE E - Referencial jurídico para orientar a ação do gerente..................... 150 


\subsection{VISÃO GERAL INTRODUTÓRIA}

Este trabalho busca destacar a importância do planejamento da Administração de Contrato, estudado a partir da perspectiva do gerenciamento de riscos, no âmbito das obras tanto públicas como privadas do segmento da construção civil pesada brasileira. De acordo com Assumpção apud Yasbek, obras de construção pesada são "obras basicamente de infra-estrutura, tais como aeroportos, portos, rodovias, obras de saneamento, usinas hidrelétricas e nucleares, obras de arte, dentre outras" (2005, p. 30).

O processo de Administração de Contrato tem o propósito de estabelecer a correta relação entre as partes compradora e vendedora, que celebram contrato com a finalidade de executar um empreendimento de engenharia, e também entre outras partes interessadas ${ }^{1}$ nele.

O ciclo da Administração de Contrato inicia-se com a assinatura do contrato entre o comprador e o vendedor ${ }^{2}$, terminando com a sua liquidação. Esse ciclo compõe-se de todas as ações envolvidas com a entrega e aceitação de obras e serviços, segundo Cavendish e Martin (1997). A finalidade dessas ações ora citadas é assegurar que o vendedor execute o contrato conforme o estabelecido e receba o pagamento adequado.

Da perspectiva do comprador, a observância dos termos do contrato significa certificar-se da sua execução pelo vendedor, no prazo e ao preço pactuados, de acordo com a qualidade que ele, comprador, estabeleceu. Da perspectiva do vendedor, significa garantir que o comprador lhe dê acesso ao local da obra, desimpedido para possibilitar a execução, e que lhe pague com pontualidade, de acordo com o contrato.

\footnotetext{
1 Adota-se para partes interessadas a definição dada pelo Project Management Institute: "pessoas e organizações, como clientes, patrocinadores, organizações executoras e o público, que estejam ativamente envolvidas no projeto ou cujos interesses possam ser afetados de forma positiva ou negativa pela execução ou término do projeto" (PMI, 2004, p. 371). Na mesma linha, e da mesma fonte, entende-se que cliente é a "pessoa ou organização que utilizará o produto, serviço ou resultado do projeto".

2 Neste trabalho, doravante, a parte que promove a licitação e/ou contrata é denominada Contratante ou comprador e a parte que é contratada para executar o objeto do contrato, é denominada Contratado, fornecedor ou vendedor.
} 
O processo de Administração de Contrato está inserido no processo de contratação do projeto ${ }^{3}$, e este, por sua vez, no do seu gerenciamento. "O processo de contratação inicia-se com o surgimento da necessidade de contratar. Daí se segue o planejamento do contrato. [...] Efetua-se a licitação e celebra-se o contrato. [...] Vem, por último, a execução do contrato" (AMARAL, 2006a, p. 214-215, grifos do autor). A citação permite identificar, no ciclo de contratação de projetos, onde se contém o da Administração de Contrato, como mostra a Figura 1.1.

É de se destacar que a prática da Administração de Contrato, sob o aspecto da gestão de projetos, não se presta ao reparo de erros cometidos em etapas anteriores à da assinatura do contrato.

Para ser eficiente, o processo de gestão de um contrato do setor da construção pesada requer planejamento, que deve ser feito antes da assinatura do contrato e tomada do risco da sua execução, isto é, antes do início do ciclo da Administração de Contrato. Mais precisamente, esse planejamento deve acontecer em paralelo com a análise do risco de execução do projeto que se deseja contratar. Este último processo alimenta o da Administração de Contrato, proporcionando-lhe as diretrizes que orientarão a formulação do seu planejamento.

$\mathrm{Na}$ maioria dos casos, a contratação de empreendimentos desenvolve-se em duas fases distintas, uma interna e a outra externa ao processo. O planejamento da contratação é feito na fase interna. A licitação, a contratação e a execução do contrato ocorrem na fase externa, a qual se inicia com a divulgação, pelo comprador, de edital ou de carta-convite ${ }^{4}$, com as exigências, diretrizes e parâmetros que nortearão - e condicionarão - todas as etapas seguintes do procedimento.

Em geral a contratação se dá mediante licitação, em que a empresa interessada, ou convidada a participar do certame, apresenta sua oferta ("proposta"), que é feita com base nas referências fornecidas pelo promotor da licitação. "O vínculo contratual nasce quando a proposta e a aceitação se integram”, afirma Gomes (2002, p. 57, grifos do autor).

3 Neste trabalho, emprega-se o termo Projeto na sua acepção ampla, como sinônimo de empreendimento, salvo onde indicado em contrário. $\mathrm{Na}$ acepção restrita do termo, projeto significa o conjunto de especificações, memoriais, desenhos e outros elementos técnicos que caracterizam o objeto do contrato, em nível de detalhe básico ou executivo. A acepção restrita é a utilizada na Lei n. 8.666, de 21 de junho de 1993 ("projeto básico" e "projeto executivo").

4 Em geral, a divulgação se dá por meio da publicação de edital, em se tratando de entidade do poder público, e pelo envio de carta-convite ou simplesmente convite, dirigido a uma ou mais de uma empresa previamente selecionadas, em se tratando de divulgação feita por empresa privada. Neste trabalho, às vezes o termo edital é utilizado com o mesmo sentido, tanto num como noutro caso. 
Assim, a relação entre as partes compradora e vendedora, encetada na licitação, materializa-se no contrato, o principal parâmetro que rege a convivência entre elas, desde o começo da execução do objeto pela parte Contratada, até sua aceitação final pela parte Contratante.

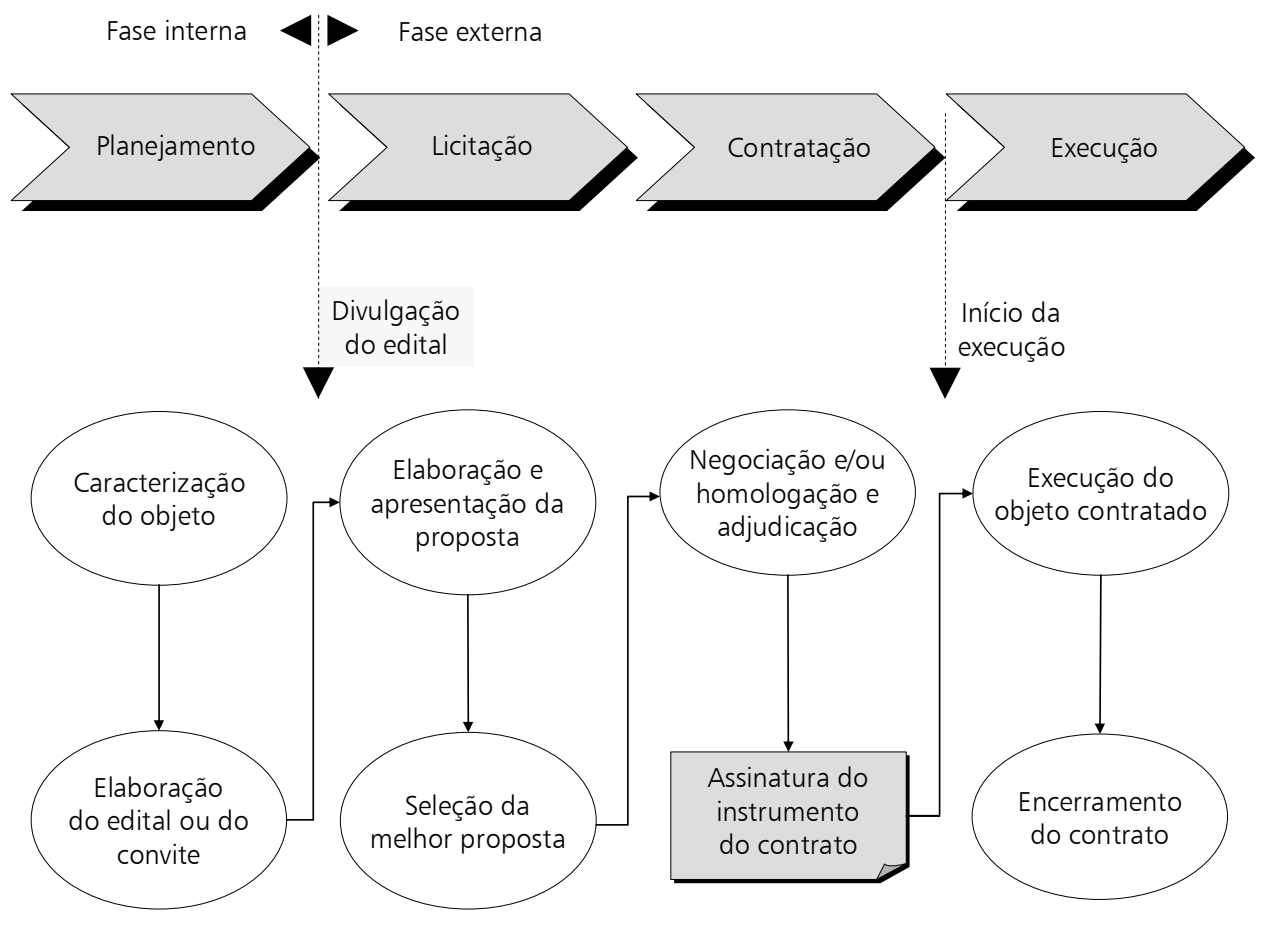

FONTE: Elaborado pelo autor.

Figura 1.1 - Etapas básicas do processo de contratação.

O contrato é estabelecido pelas partes para regulação dos próprios interesses, a partir de um conjunto de funções logicamente estruturadas, com fundamentação legal, constituindo uma fonte de obrigações para ambas as partes. O documento ("instrumento") não é por si só o contrato. Não é o documento que dá existência ao contrato mas sim o encontro de declarações convergentes de vontade: o documento formaliza a vontade (GOMES, 2002).

Amaral considera que "um bom contrato é aquele que satisfaz as partes. Mas um bom contrato é também aquele que é bem gerido pelas partes” (2006a, p. 215). No Brasil, as entidades do setor público celebram contratos em que a parte contratante age com supremacia de poder sobre a 
contratada, por gozar de prerrogativas especiais. Tais contratos denominam-se contratos administrativos e as licitações que lhes dão origem são regidas por legislação própria ${ }^{5}$.

A existência do documento precede a sua aplicação, portanto pode-se dizer que a elaboração de contratos, particularmente em projetos de construção pesada, é um exercício de percepção de acontecimentos futuros, por meio de conjecturas. Carnelutti confirma essa imagem, asseverando que: "o contrato implica [...] uma projeção para o futuro: tem a finalidade de estabelecer para o porvir certas posições de hoje; por isso é que implica uma promessa recíproca, e a promessa é uma declaração que se refere ao futuro" (2000, p. 41, tradução nossa).

$\mathrm{Na}$ execução de contratos de construção pesada, é freqüente a ocorrência de acontecimentos geradores de disputas, a despeito da vontade das partes e do intuito da proposta.

Eventos como problemas técnicos inesperados, questões de qualidade ou de confiabilidade, solicitações de mudanças nas especificações técnicas, mudanças determinadas por novos requisitos de desempenho ou pela disponibilidade de novas tecnologias, entre outros, podem provocar o desequilíbrio econômico-financeiro do contrato, comprometendo a sua execução. Meredith e Mantel Jr. dizem que "as mudanças mais comuns, todavia, são devidas à tendência natural do cliente e de membros da equipe de projeto de tentarem melhorar o produto ou serviço" (2003, p. 351).

Os eventos acima citados - que não podiam ser imaginados por ocasião do planejamento da contratação do Projeto - podem ensejar disputas. As disposições contratuais serão interpretadas, servindo de base ao processamento de reivindicações que podem levar a litígios. Colocada a disputa, o gerente tem o dever de atuar, para garantir a continuidade do contrato sob seu comando. Controlar e solucionar demandas constituem responsabilidades críticas do gerente do contrato.

Os problemas podem ser evitados ou resolvidos mediante a aplicação consistente dos preceitos de gerenciamento de projetos, segundo dizem Dinsmore e Silveira Neto (2005), ressaltando que

\footnotetext{
5 Na data de divulgação deste trabalho achavam-se em vigor, entre outras, as seguintes leis federais pertinentes ao tema: (i) Lei n. 8.666, de 21/06/1993, e suas alterações complementares, que "estabelece normas gerais sobre licitações e contratos administrativos pertinentes a obras, serviços [...], compras, alienações e locações no âmbito dos Poderes da União, dos Estados, do Distrito Federal e dos Municípios"; (ii) Lei n. 8.987, de 13/02/1995, e Lei n. 9.074, de 07/07/1995, que dispõem sobre o regime de concessão e permissão da prestação de serviços públicos, e sobre sua outorga e prorrogações; e (iii) Lei n. 11.079, de 30/12/2004, que "institui normas gerais para licitação e contratação de parceria público-privada no âmbito da administração pública".
} 
alguns dos problemas têm características fortemente técnicas; outros são marcados pelo comportamento humano, enquanto a maioria é afetada por fatores tanto técnicos como comportamentais. Afirmam esses autores: “[...] é cada vez mais claro que é necessária uma forte dose de comportamento gerencial para executar aquelas tarefas básicas e adaptá-las às situações especiais de cada projeto" (2005, p. 25).

As principais técnicas e habilidades do gerente, necessárias para o controle e solução de demandas em projetos de construção pesada, constituem o foco dos dois Estudos de Caso abordados nesta dissertação. Como se verá adiante no Capítulo 5, um dos Estudos de Caso foi realizado sob a óptica da parte Contratante, e o outro, da parte Contratada.

\subsection{RELEVÂNCIA DO TEMA ABORDADO}

O início da década de 90 assinalou, no Brasil, uma significativa mudança nas obras do setor da construção pesada, ocasionada principalmente pela escassez de recursos financeiros baratos, pelo processo de privatização e pela abertura do setor à participação de empresas estrangeiras, passando o mercado a ser francamente de oferta. A contratação da execução de projetos de construção pesada tornou-se um processo complexo, refletindo um novo modelo de relação entre as partes celebrantes do contrato.

Antes, o promotor do empreendimento - o Estado, na quase totalidade dos casos - segmentavao segundo a natureza dos diversos trabalhos requeridos à sua realização, tais como a elaboração de projeto básico e/ou executivo, a execução de obras civis, a execução de serviços especializados, e o fornecimento de bens e equipamentos sob encomenda. A execução de cada segmento era contratada pelo regime de preços unitários, cabendo ao dono do projeto promover o gerenciamento e integração das diversas partes componentes do todo.

Atualmente, tanto o Estado como a iniciativa privada licitam projetos de construção pesada, e o fazem geralmente sem desdobrá-los, contratando a totalidade da sua execução a preço global, independentemente da variação de tipos e quantidades de serviços, além de imputar à parte contratada a responsabilidade pela entrega do objeto na condição "pronto para operar". 
A gestão de projetos se refere, entre outros quesitos, “à aplicação de conhecimentos, habilidades, técnicas e instrumentos às atividades do empreendimento, a fim de alcançar ou exceder as expectativas dos seus agentes” (PMI, 2002, p. 6). Isto exige do gerente de projetos e dos integrantes da sua equipe de gerenciamento ${ }^{6}$ - sejam eles representantes da parte Contratante, seja da parte Contratada - competência para executar bem as suas funções. Competência, segundo Fleury e Fleury (2000, p. 21), é “um saber agir responsável e reconhecido, que implica mobilizar, integrar, transferir conhecimentos, recursos, habilidades, que agreguem valor econômico à organização e valor social ao indivíduo”.

O cenário relatado anteriormente sugere que a sobrevivência e o crescimento da empresa atuante no setor da construção pesada no Brasil, especialmente quando o faz na condição de parte Contratada, exige competência em gerenciamento e depende, entre outros fatores, do contínuo aprimoramento do processo de contratação e execução de Projetos, requerendo o aperfeiçoamento incessante de formas de agir que reduzam o risco e otimizem os resultados esperados.

No Capítulo 3 desta dissertação, ver-se-á que a Administração de Contrato é uma dessas práticas, constituindo um instrumento indispensável à preservação do equilíbrio econômico-financeiro inicial do contrato, bem como ao seu restabelecimento, "na hipótese de sobrevirem fatos imprevisíveis, ou previsíveis porém de conseqüências incalculáveis, retardadores ou impeditivos da execução do ajustado, [...] configurando álea econômica extraordinária e extracontratual’”7.

O Project Management Institute, no seu trabalho Um guia do conjunto de conbecimentos em gerenciamento de projetos - Guia PMBOK - Terceira edição (2004), considera que a Administração de Contrato constitui um dos processos $^{8}$ inclú́dos na área de conhecimento sobre gestão de aquisições do Projeto, tratando das entradas, ferramentas e técnicas, e saídas desse processo. É

6 Neste trabalho utilizam-se os termos equipe e membros da equipe com o seguinte sentido: "as pessoas que se reportam direta ou indiretamente ao gerente de projetos e que são responsáveis pela realização do trabalho do projeto como parte normal das tarefas que lhes foram atribuídas" (PMI, 2004, p. 368, grifo do autor). Por sua vez, trabalho é definido pela mesma fonte como "esforço, empenho ou exercício físico ou mental sustentado de habilidade para superar obstáculos e atingir um objetivo” (PMI, 2004, p. 378).

7 Lei n. 8.666, de 21/06/1993, art. 65, alínea “d” do inciso II, com redação dada pela Lei n. 8.883, de 08/06/1994.

8 Os processos citados na edição de 2004 são seis: (1) planejar compras e aquisições, (2) planejar contratações, (3) solicitar respostas de fornecedores, (4) selecionar fornecedores, (5) administração de contrato e (6) encerramento do contrato. 
interessante observar que essa inclusão constitui uma novidade, pois não constou das duas edições anteriores ${ }^{9}$ do Guia PMBOK.

É possível afirmar que, até meados da década de 90, a formulação e apresentação de reivindicações, em decorrência da prática da Administração de Contrato, constituía um requinte adotado por poucas empresas. "A administração de contratos é uma prática recente em empresas de grande porte e ainda pouco usual em empresas menores", dizem Pedrosa e Rocha Lima Jr., (1994, p. 2).

\subsection{OBJETIVOS E DELIMITAÇÃO DA PESQUISA}

O objetivo primeiro deste trabalho é o de proporcionar uma síntese hierarquizada dos requisitos mais influentes à prática da Administração de Contrato, bem como dos fatores que influenciam o atendimento de reivindicação contratual apresentada pelo fornecedor ao comprador, delineadas a partir da perspectiva do processo de gerenciamento de riscos, que oriente o planejamento da Administração de Contrato e que seja aplicável a empresas que executam contratos do setor da construção pesada no Brasil. Com a indicação desse quadro referencial, espera-se contribuir para a solução de disputas contratuais que ocorrem nesse segmento de mercado com grande freqüência.

Para os fins de determinação dos objetivos acima, são investigados os pontos de vista de duas importantes organizações brasileiras, ambas com presença significativa no mercado da construção pesada, a respeito: (i) dos principais fatores que afetam a gestão de projetos e a administração de contratos, (ii) das habilidades do Gerente que mais influem na boa prática dos processos mencionados na alínea anterior e (iii) dos requisitos básicos para a solução de litígios contratuais.

O termo Gerente, neste trabalho, é empregado para designar o responsável pela implantação ou execução de um Projeto completo, ou das frações que o compõem, liderando uma equipe de auxiliares que respondem diretamente a ele.

9 Editadas pelo Project Management Institute sob os títulos A guide to the Project Management Body of knowledge, em 1996 (edição exclusivamente em inglês, com 76 p.) e Um guia do conjunto de conbecimentos do gerenciamento de projetos PMBOK Guide: edição 2000. A edição em português (218 p.) foi publicada em 2002. A tradução para o português da terceira edição do "PMBOK" foi editada em 2004, contendo 388 p. 
Esta pesquisa não tem o intuito de estabelecer uma regra rígida sobre planejamento de Administração de Contrato, que seja aplicável a qualquer situação. Ao contrário, o propósito é o de estabelecer um quadro referencial sobre o tema, configurado a partir de uma base conceitual sólida, cuja utilização permita ao Gerente conduzir a execução de empreendimentos de acordo com as respectivas disposições contratuais, caso a caso. Também não tem o intuito de discutir ou comparar a função de Gerente nas organizações onde os levantamentos de campo tiveram lugar.

A pesquisa tampouco visa avaliar práticas gerenciais das empresas cujos profissionais participaram dos Estudos de Caso 1 e 2 realizados ("EC-1" e "EC-2") "10, nem discutir dispositivos ou aspectos da legislação em vigência no País, pertinente a licitações e contratações do setor público brasileiro.

\subsection{MÉTODO DE DESENVOLVIMENTO DA DISSERTAÇÃO}

Este trabalho sobre Administração de Contrato busca contribuir para aprimorar o conhecimento sobre o tema, preocupando-se com sua aplicação prática, a partir da consolidação de uma base conceitual. Para atingir esse fim, foi desenvolvida uma pesquisa exploratória que seguiu os ensinamentos de Gil (2002) e Yin (2005), envolvendo: (a) pesquisa bibliográfica, (b) a realização de dois Estudos de Caso, para conduzir uma reflexão crítica sob dois diferentes pontos de vista, o da parte Contratante e o da Contratada, e (c) a realização de uma entrevista com profissional de notório saber jurídico, para fixação do indispensável alicerce legal do assunto em pauta. As etapas-chave de desenvolvimento do trabalho estão mostradas na Figura 1.2.

\section{a) Pesquisa bibliográfica.}

Com a pesquisa bibliográfica realizada buscou-se, primeiramente, estabelecer os elementos de subordinação do processo de Administração de Contrato ao de Gerenciamento de Riscos, distinguindo-os e analisando características, funções e interfaces, bem como fatores que têm influência nesses processos, tudo considerado a partir da perspectiva dos "membros da

10 Nesta dissertação, a metodologia dos Estudos de Caso 1 e 2 é apresentada de maneira sucinta no item 1.4 do Capítulo 1 e de forma mais detalhada no Capítulo 5, no qual também são analisados os dados obtidos. 
equipe que estão diretamente envolvidos nas atividades de gerenciamento de projetos" (PMI, 2004, p. 368).

Num segundo momento, procurou-se discutir o contrato, em razão de ser esse o instrumento que materializa a relação estabelecida de comum acordo entre o comprador e o vendedor, por meio da fixação de um conjunto de regras ("cláusulas") que estabelece as condições para o alcance dos objetivos das partes, sobretudo suas obrigações e responsabilidades, que se complementam e interdependem. O instrumento de contrato, ainda que não restrinja a ação do gerente, pode dificultá-la e até inibi-la. O que restar escrito terá grande influência, tanto de fato como de direito, na execução do objeto contratado. Logo, é imprescindível que o gerente saiba como avaliar o contrato antes de assiná-lo.

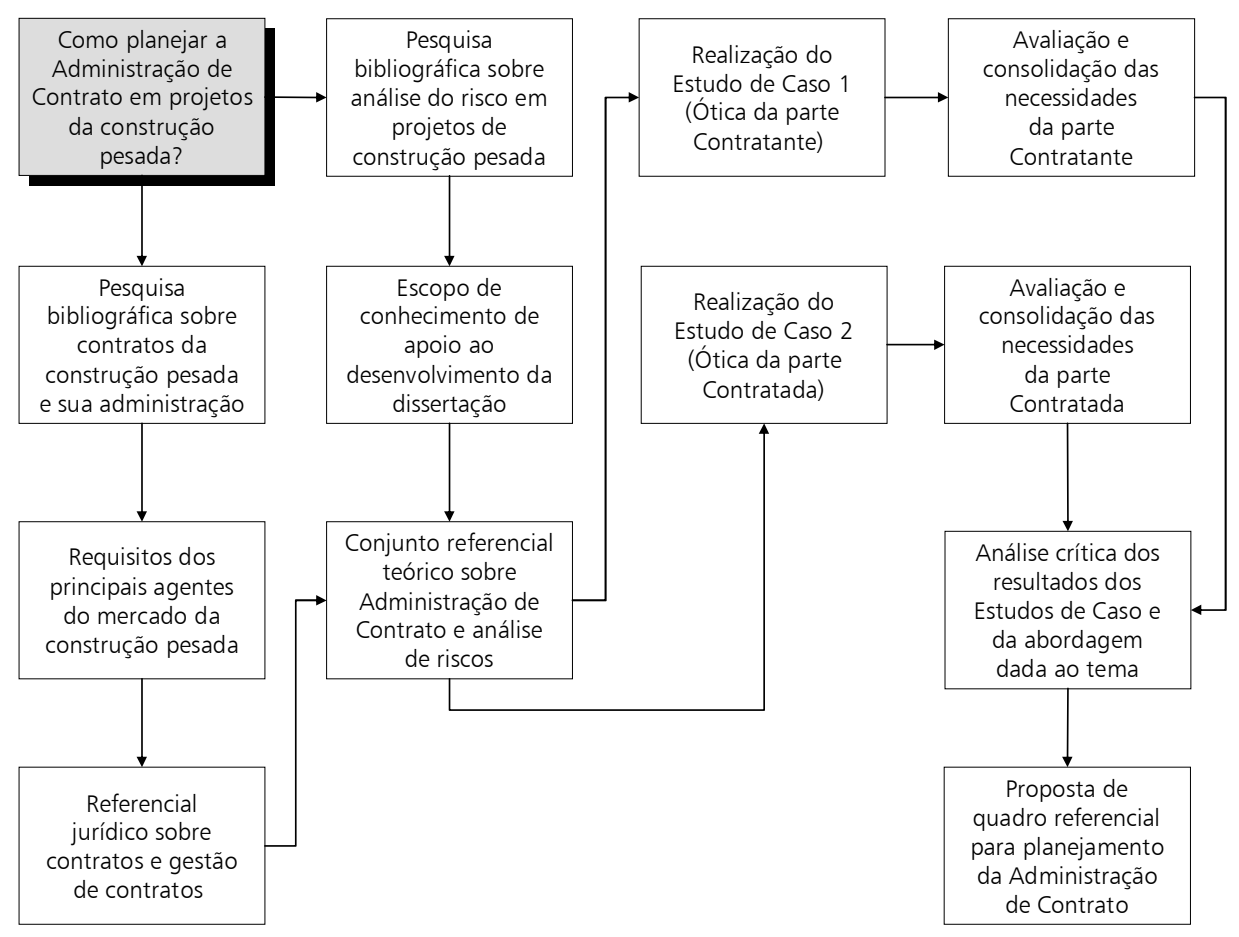

FONTE: Elaborado pelo autor.

Figura 1.2 - Fluxograma das principais etapas de desenvolvimento do trabalho.

Na seqüência, procedeu-se ao estudo das faces estratégica e tática da Administração de Contrato, por meio do exame da sua abrangência, dos momentos de tomada de decisão e dos papéis das partes contratante e contratada, bem como das técnicas e habilidades requeridas dos gerentes, para o melhor desempenho das suas funções. 
Finalmente, a pesquisa bibliográfica tratou do processo de gerenciamento de riscos, no que tange à etapa de identificação e análise do risco, por assinalar o momento em que surge o plano de administração contratual.

\section{b) Estudos de Caso.}

Foram realizados dois Estudos de Caso: neles, procurou-se captar as ópticas das equipes de gerenciamento de projetos das partes contratante e contratada, com relação ao tema objeto da dissertação.

O Estudo de Caso é, segundo Yin (2005), o tipo de estratégia mais relevante para delineamento da pesquisa realizada. Essa constatação a respeito do tipo de estratégia decorre do enquadramento do tema às três condições apresentadas por Yin na sua obra, isto é, a forma da questão de pesquisa (“como, por que”), a não exigência de controle sobre eventos comportamentais efetivos e a focalização em acontecimentos contemporâneos. O desenho dos Estudos de Caso 1 e 2 foi feito mediante a definição do seguinte conjunto de etapas (GIL, 2002; YIN, 2005): (i) formulação do problema, com base num processo de reflexão e imersão em fontes bibliográficas; (ii) definição das duas organizações que constituem as unidades-caso; (iii) elaboração dos respectivos protocolos; (iv) coleta dos dados; (v) avaliação e análise dos dados; e (vi) narrativa da interpretação dos resultados obtidos.

\section{c) Entrevista.}

O procedimento recomendado no Capítulo 6 delineia um quadro referencial para orientar o gerente nas tomadas de decisão, visando a solução de demandas contratuais, caso a caso. Por esse motivo, foram duas as preocupações básicas que nortearam esse delineamento. Primeira, construí-lo a partir de orientação jurídica, e segunda, não perder de vista o caráter interdisciplinar e coletivo do trabalho gerencial, particularmente nas ações ligadas à Administração de Contrato.

De fato, por mais informado que seja, na maioria dos casos o gerente não tem habilitação jurídica para decidir, dependendo da informação de outras áreas para fazê-lo. O PMI ressalta que "a natureza legal da relação contratual torna imperativo que a equipe de gerenciamento de projetos esteja profundamente a par das implicações legais das ações tomadas durante a administração de qualquer contrato" (2004, p. 290). 
As mencionadas implicações legais constituem o foco da entrevista realizada com um advogado. A entrevista consta, na íntegra, do APÊNDICE E desta dissertação, e fornece as bases legais do tema nela tratado.

\subsection{ARRANJO DO TRABALHO}

Considerando os seus objetivos, a dissertação está organizada segundo a relevância do assunto na ordem de leitura. O Capítulo 2 - "Contratos de projetos de construção pesada" abarca os conceitos básicos para a compreensão do processo de contratação de empreendimentos do setor da construção pesada, analisando as vantagens e desvantagens de alguns tipos de contratos e identificando as cláusulas contratuais críticas, que podem afetar o relacionamento entre as partes Contratante e Contratada. O Capítulo 3 - "Aspectos da Administração de Contrato" descreve as principais características do processo de administração contratual, detendo-se nos exames da origem e da solução de reivindicações decorrentes de fatos extraordinários, que costumam surgir durante a execução de contratos.

O Capítulo 4 - "Interface entre os processos de Administração de Contrato e de análise do risco" investiga como se dá a tomada de decisão do gerente, de assinar um contrato para executar um empreendimento de construção pesada, num ambiente de incerteza, de um ponto de vista das necessidades das partes contratante e contratada. O Capítulo 5 - "Apresentação dos Estudos de Caso realizados" avalia e interpreta os dados apurados nos Estudos de Caso 1 e 2, analisando criticamente o tratamento dado ao tema da dissertação, por intermédio de duas comparações: a primeira, entre o ponto de vista da Contratante e o da Contratada, e a segunda, entre tais pontos de vista e o referencial teórico estabelecido.

O título do Capítulo 6 - "Requisitos do planejamento da Administração de Contrato" antecipa ao leitor o seu conteúdo. As recomendações feitas neste capítulo incluem a apresentação de listas de verificação, que facilitam a aplicação do procedimento sugerido a casos concretos. Finalizando a exposição dos elementos textuais da dissertação, o Capítulo 7 - “Considerações finais" sintetiza o conjunto de referências proposto para planejar a gestão de contratos do setor da construção pesada, e acena para possíveis desdobramentos que este trabalho poderá proporcionar. 
Há, ainda, elementos pós-textuais, iniciados com a apresentação de duas relações de obras consultadas sobre contratos da construção pesada e sua administração, e sobre identificação e análise do risco. A lista intitulada "Referências bibliográficas" exibe as publicações utilizadas na elaboração deste trabalho, enquanto o rol constante da "Bibliografia consultada" mostra outras publicações, que foram estudadas em apoio ao trabalho. Uma e outra relação poderão contribuir para que cresça o conhecimento relativo à prática de Administração de Contratos.

Segue-se um conjunto de cinco APÊNDICES, identificados de "A" até "E". Os quatro primeiros trazem informações sobre os Estudos de Caso 1 e 2, revelando o questionário enviado aos entrevistados, a coleta, a apuração de dados e o teste de significância estatística dos dados apurados nos dois Estudos de Caso. O quinto e último APÊNDICE reproduz integralmente a entrevista concedida por um jurisconsulto ao autor desta dissertação, em caráter de exclusividade.

A seqüência de execução das atividades referidas anteriormente, concernentes aos Estudos de Caso 1 e 2, acha-se esquematizada na Figura 1.3, que também mostra o arranjo, na dissertação, do lugar de apresentação das informações pertinentes ao desenrolar dessas atividades.

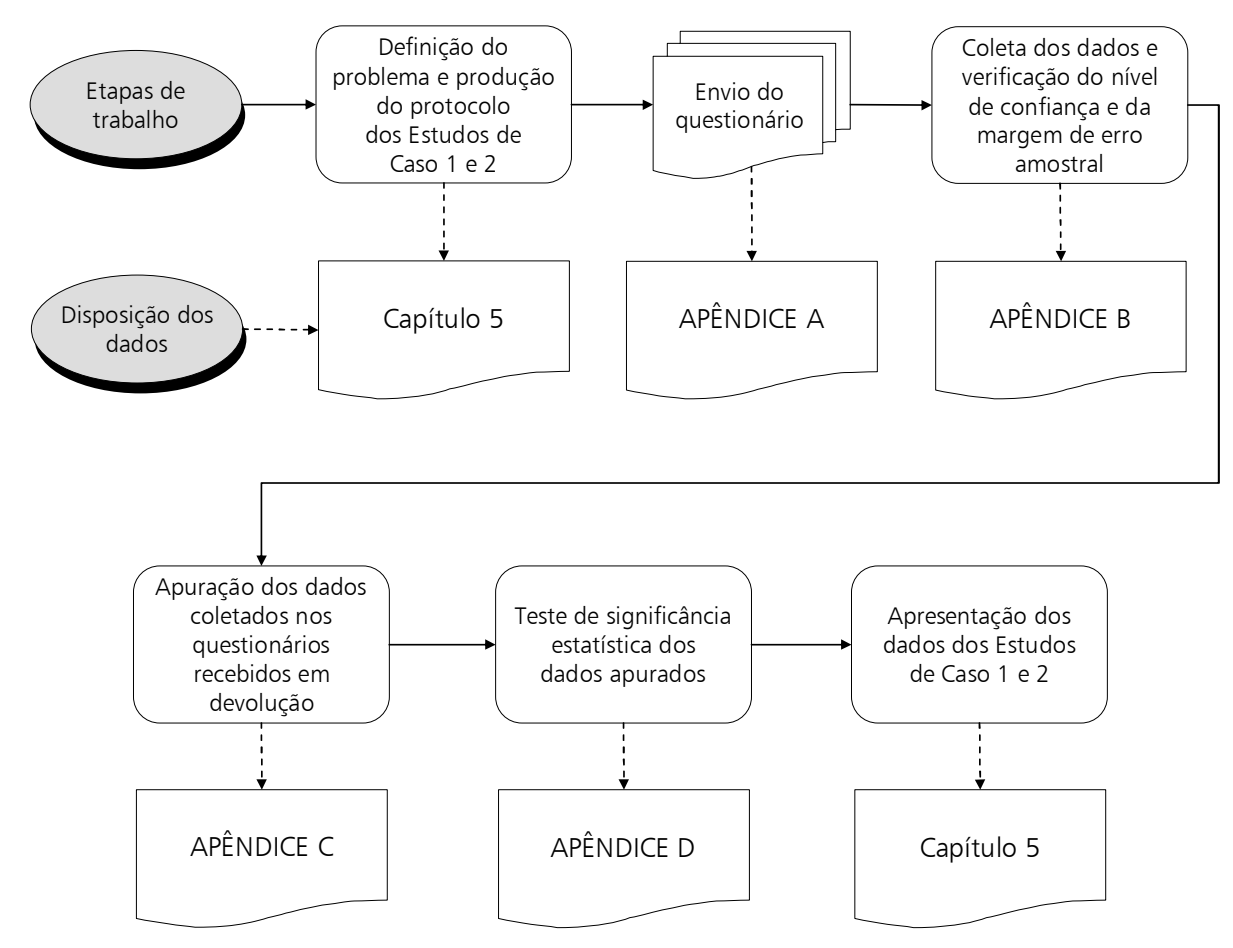

FONTE: Elaborado pelo autor.

Figura 1.3 - Mapa da disposição de dados dos Estudos de Caso 1 e 2. 


\section{CONTRATOS DE PROJETOS DE CONSTRUÇÃO PESADA}

Os contratos devem ser sagazes e adiantar-se aos acontecimentos.

(Claudia Rojas e Humberto Maldonado)

\subsection{CONVIVENDO COM A INCERTEZA}

O progresso é feito pela identificação e aproveitamento de oportunidades; uma vez identificada a oportunidade, a forma mais direta de se aproveitá-la é estabelecer um projeto, diz Wideman (1992). Na acepção ampla do termo ${ }^{11}$, Projeto é "uma organização designada para cumprimento de um objetivo, criada com esse objetivo e dissolvida após a sua conclusão. Caracteriza-se por ser temporária, ter um início e um fim bem definidos e obedecer normalmente a um plano" (ROLDÃO, 2000, p. 5).

Por obedecer geralmente a um plano, uma das principais características do Projeto é a sua singularidade. O produto de um Projeto é diferente, de algum modo, do produto de outros projetos congêneres, pressupondo que ao longo da execução são feitas coisas novas, nunca feitas anteriormente (PMI, 2002).

Os conceitos de temporariedade e de singularidade integram-se numa outra característica dos projetos, a da elaboração progressiva, por etapas consecutivas (PMI, 2004). Tais características permitem concluir que a incerteza é inseparável dos Projetos, especialmente os que envolvem obras de construção pesada. A dúvida, a variabilidade e a inconstância são inerentes às atividades desenvolvidas pelos integrantes da equipe de gerenciamento de Projetos e influem, em maior ou menor grau, em toda e cada uma das ações que engendrarem.

No setor da construção pesada, em geral o contrato resulta de um processo de licitação e constitui o produto final do acordo entre o comprador e o vendedor, derivando de uma proposta, como foi comentado no Capítulo 1. Por sua vez, a proposta é apresentada com base nos parâmetros fornecidos pelo comprador, compreendendo, entre outros, a minuta do

\footnotetext{
11 A distinção entre as acepções ampla e restrita do termo projeto consta do Capítulo 1.
} 
instrumento de contrato, memoriais descritivos, desenhos e especificações técnicas, que caracterizam o escopo a ser contratado. A Figura 2.1 ilustra a seqüência lógica de formação do contrato, exprimindo a importância do edital ou do convite, cujas eventuais falhas repercutirão até o encerramento do contrato.

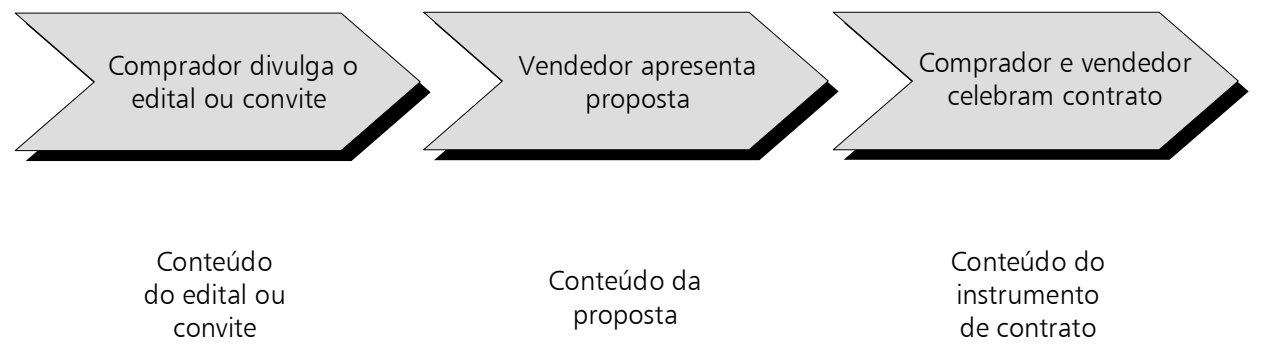

\begin{tabular}{|c|c|c|c|c|}
\hline $\begin{array}{l}\text { - Condições de } \\
\text { participação } \\
\text { - Exigências de } \\
\text { habilitação } \\
\text { - Exigências de } \\
\text { natureza técnica e } \\
\text { comercial } \\
\text { - Projeto Básico ou } \\
\text { Projeto Executivo } \\
\text { - Minuta do } \\
\text { instrumento de } \\
\text { contrato }\end{array}$ & + & $\begin{array}{l}\text { - Documentação } \\
\text { comprobatória de } \\
\text { participação e } \\
\text { habilitação } \\
\text { - Indicação de } \\
\text { métodos e processos } \\
\text { construtivos } \\
\text { - Detalhamento } \\
\text { executivo do prazo } \\
\text { estabelecido pelo } \\
\text { comprador } \\
\text { - Preço }\end{array}$ & $=$ & $\begin{array}{l}\text { - Cláusulas } \\
\text { - Documentos anexados } \\
\text { ao contrato, entre os } \\
\text { quais: } \\
\text { - Os esclarecimentos } \\
\text { prestados durante a } \\
\text { licitação e contratação } \\
\text { - A proposta } \\
\text { - O edital ou convite } \\
\text { e seus anexos }\end{array}$ \\
\hline
\end{tabular}

FONTE: Elaborado pelo autor.

Figura 2.1 - Formação das peças integrantes do contrato.

No mercado da construção pesada, o conjunto de informações técnicas de engenharia é denominado de projeto básico ou projeto executivo, dependendo do estágio da qualidade dos elementos que o integram. Kertzner (2001) classifica as estimativas feitas a partir de informações técnicas de engenharia em 6 diferentes níveis, atribuindo uma margem de erro a cada um, como mostra a Tabela 2.1. Mesmo nos casos de estimativas provenientes de projetos em nível executivo (ou "definitivo", segundo esse autor), são admitidos desvios para mais e para menos, em outra evidência de que é muito alta a probabilidade de haver mudanças nos planos originais para execução do empreendimento, antes do encerramento do respectivo contrato. À medida que a informação é aprimorada, reduz-se o erro admissível. 
Pode-se dizer que a qualidade desse conjunto de informações tem influência direta no processo de análise do risco de execução do empreendimento e, em conseqüência, na decisão de tomá-lo.

Tabela 2.1 - Classificação das estimativas de custo.

\begin{tabular}{cc}
\hline Fonte da estimativa & \% de erro admissível \\
\hline Projeto definitivo & $\pm(5 \%)$ \\
Projeto básico & $\pm(10$ a $15 \%)$ \\
Anteprojeto & $\pm(15$ a $20 \%)$ \\
Projeto esquemático & $\pm(20$ a $25 \%)$ \\
Projeto na fase de viabilidade & $\pm(25$ a $30 \%)$ \\
Ordem de grandeza & Maior que $( \pm 35 \%)$ \\
\hline
\end{tabular}

FONTE: Kertzner (2001, p. 745, tradução do autor).

Mintzberg e Westley (2001) afirmam que há três modelos distintos de tomada de decisão: (i) "pensar primeiro", um modelo racional, eficiente quando o problema a ser resolvido é claro; (ii) "ver primeiro", o modelo que estimula as soluções criativas, fazendo com que seja visto antes o que outros não souberam ver; e (iii) "fazer primeiro", o modelo experimental, bom para ser utilizado em problemas confusos. Concluindo, os autores dizem que os três modelos são importantes e devem ser aplicados de maneira sinérgica, segundo as características do problema, e que a qualidade da informação condiciona, caso a caso, a adoção do (ou dos) modelo(s) mais adequado(s).

Antes da assinatura do contrato, o Gerente e os integrantes da sua equipe de gestão comprometem-se com o método construtivo e com metas de prazo e valores de execução do projeto, tomando por referência as informações fornecidas no edital de licitação, entre as quais se inclui a minuta do instrumento de contrato.

$\mathrm{Na}$ fase de execução do contrato, para atingir as metas pré-estabelecidas utilizam-se processos de gerenciamento. O PMI (2004) distingue processos que envolvem nove áreas de conhecimento: 
escopo, integração, tempo, custo, qualidade, risco, recursos humanos, comunicação e aquisições, incluindo, no último processo, o de Administração de Contrato ${ }^{12}$.

$\mathrm{O}$ atendimento às especificações e finalidades de um Projeto requer, além de metas claras e definidas, a obediência a uma seqüência lógica e concatenada de atividades. Para atingir ou superar as expectativas dos interessados no empreendimento, é necessário que o gerente promova o equilíbrio entre fatores que interagem, tais como escopo, tempo, custo e qualidade do projeto, e que leve em conta a presença de interessados com diferentes necessidades e expectativas, gerando exigências por competirem entre si.

Diversos outros acontecimentos, de ocorrência simultânea, influem na modelagem do relacionamento entre as partes que desejam contratar, destacando-se dentre eles:

- A escolha de parceiros estratégicos, tais como projetistas, empresas fornecedoras de bens e prestadoras de serviços;

- O estudo das especificações do empreendimento, seja para detalhar um "projeto básico", tornando-o executivo, seja para investigar a possibilidade da introdução de melhorias, gerando alternativas; e

- A identificação e mobilização de recursos humanos com qualificação específica para planejar e executar o empreendimento.

\subsection{CARACTERÍSTICAS PRINCIPAIS DE ALGUMAS MODALIDADES DE CONTRATOS}

A doutrina jurídica conceitua contrato como "o acordo de duas ou mais vontades, na conformidade da ordem jurídica, destinado a estabelecer uma regulamentação de interesses entre as partes, com o escopo de adquirir, modificar ou extinguir relações jurídicas de natureza patrimonial” (Diniz apud Sampaio, 2004, p. 21).

\footnotetext{
Modernamente, entende-se por contrato o negócio jurídico (espécie de ato jurídico) bilateral que tem por finalidade gerar obrigações entre as partes. Sob esse aspecto, portanto, o acordo de vontades a que chegam as partes tem objetivo certo, efeito este antevisto pelas partes (intuitu negocial) que se consubstancia na criação, modificação ou extinção de direitos. Segundo Orlando Gomes, os contratos têm alguns traços característicos que os diferenciam de outras figuras jurídicas, em que também se faz
}

\footnotetext{
12 O PMI entende que no gerenciamento de aquisições do Projeto há 4 processos que antecedem o de Administração de Contrato ("Planejar compras e aquisições", "Planejar contratações", "Solicitar respostas de fornecedores" e "Selecionar fornecedores") e 1 processo que o sucede ("Encerramento do contrato").
} 
presente a necessária convergência de vontades. Isto é, em que pese à coincidência de declarações ou convergência de vontades ser essencial ao aperfeiçoamento do contrato, este tem algumas características peculiares:

(1) necessidade de o acordo de vontades ter por finalidade gerar obrigações às partes e não simples regras de condutas, o que ocorre, por exemplo, com os acordos normativos;

(2) plurititularidade - consiste na co-participação de sujeitos de direito com interesses econômicos contrapostos [...];

(3) noção de parte como centro de interesses e não como pessoa física ou jurídica. Fato este que explicaria uma única pessoa representando ambas as partes (autocontrato ou contrato consigo mesmo). (SAMPAIO, 2004, p. 21-22).

Há uma distinção básica que deve ser feita entre os contratos celebrados entre empresas privadas ("contrato de direito privado") e os contratos em que a parte contratante é uma entidade do setor público ("contrato administrativo"). A respeito dessa diferença, Amaral (2006b) assim se manifesta:

Os contratos atribuem direitos e obrigações às partes que os celebram. Suas cláusulas devem ser observadas e cumpridas. O princípio básico dos contratos em geral é o "pacta sunt servanda", ou seja, os pactos devem ser cumpridos.

Eles têm a função de realizar interesses específicos das partes. Daí decorre uma distinção importante entre contratos celebrados por pessoas privadas e contratos administrativos. Aqueles têm por função realizar interesses privados, situados no mesmo plano, enquanto estes têm por função realizar o interesse público, que se sobrepõe ao interesse privado da contratada.

As partes no contrato de direito privado podem, durante sua execução, livremente alterar o que ajustaram, desde que haja consenso e as novas regras contratuais - assim como as regras originais - não sejam proibidas por lei. Nos contratos administrativos, a Administração pode alterar unilateralmente as regras pactuadas, desde que para tal tenha amparo na legislação aplicável (Constituição e legislação administrativa, especialmente a Lei 8.666/93) e vise à satisfação do interesse público. Esta é uma exceção ao princípio "pacta sunt servanda", observando-se que, nessa hipótese, a contratada tem direito ao "equivalente econômico". Ou seja: nos contratos administrativos, a contratada não tem direito à imutabilidade do contrato, mas sim ao respeito à equação econômica inicial.

Nos contratos de direito privado, as partes podem pactuar ou repactuar o que não seja proibido por lei, enquanto nos contratos administrativos a Administração somente pode pactuar ou repactuar o que é autorizado por lei. No primeiro caso, vale o princípio de que o que não é proibido é permitido. No segundo, o de que o que não é permitido é proibido. (AMARAL, 2006b).

Caracterizada a diferença entre o contrato de direito privado e o contrato administrativo, também é preciso saber se o Gerente deve se comportar de maneira igual ou diferente, na gestão de um e de outro contrato.

Há que distinguir, a meu ver, a gestão do contrato e a gestão do empreendimento. São duas funções distintas, se bem que possam ser exercidas pelo mesmo gestor. Não vejo diferença substancial entre a gestão de um contrato de direito privado e a de um contrato administrativo, salvo a de que eles se submetem a regimes jurídicos diversos, 
um ao Código Civil, o outro à Constituição, à legislação administrativa (especialmente à Lei 8.666/93) e apenas supletivamente ao Código Civil.

A gestão do contrato é uma atividade necessariamente multidisciplinar. Está sujeita a controles, tanto nos contratos de direito privado, quanto nos contratos administrativos. Nos primeiros, o controle é dos sócios ou acionistas, exercido com o auxílio de auditorias internas ou externas. Nos contratos administrativos, o controle externo é dos tribunais de contas, do Ministério Público, do Judiciário e sobretudo, por se tratar de aplicação de dinheiro público, da sociedade e da mídia.

O gestor, porém, não é um órgão de controle. A ele cabe diligenciar no sentido de que as obrigações contratuais sejam cumpridas, tanto pela contratante quanto pela contratada. Sem esquecer, porém, que seus atos são suscetíveis de questionamento pelos órgãos de controle.

Neste ponto, penso que costuma haver uma distorção na atividade de muitos gestores de contratos. O gestor da contratante costuma ver sua função como sendo a de cobrar o cumprimento das obrigações pela contratada. E vice-versa. Não se apercebem de que aos dois gestores cabe, igualmente, buscar a eficácia da contratação, o que somente se consegue mediante o cumprimento das obrigações das duas (ou mais) partes. (AMARAL, 2006b).

O acordo entre as partes contratante e contratada deve ser equilibrado, isto é, deve pautar-se por uma política clara e coerente de distribuição do risco, criando uma base firme para a resolução das controvérsias que possivelmente ocorrerão ao longo da execução do empreendimento (FIDIC, 1999).

O formato de um contrato deve refletir o equilíbrio mencionado. Contratante e contratada chegam ao acordo porque juntos pretendem atingir um objetivo comum, embora seus interesses sejam dessemelhantes. As partes firmam o contrato para disciplinar tais objetivos e interesses.

$\mathrm{Na}$ elaboração de minutas de contratos costumam-se utilizar referências provenientes de diversas fontes, entre as quais se destacam a American Society of Civil Engineers - ASCE, a Engineering Advanced Association of Japan - ENAA, a Fédèration Internationale des Ingénieurs-Conseils FIDIC e o Institute of Civil Engineers - ICE. As condições contratuais elaboradas por esses organismos são freqüentemente usadas para atender às exigências de organismos financiadores de projetos de infra-estrutura, tais como o "Banco Mundial"13.

A informação jurídica orienta, condiciona e sustenta a ação do Gerente. Por isso lhe é indispensável deter um mínimo de conhecimento dessa natureza, sem o qual não conseguirá planejar adequadamente suas ações, nem se posicionar frente aos acontecimentos. Esse conhecimento mínimo pode ser caracterizado pelos seguintes aspectos: (i) restrições legais do empreendimento; (ii) conhecimento elementar das leis que regem o contrato; (iii)

13 International Bank for Reconstruction and Development - IBRD. 
responsabilidades assumidas ao assinar o contrato; (iv) princípios básicos da licitação pública; (v) conhecimento elementar dos princípios que regem os contratos; e ( $v i)$ características de cada tipo de contrato.

Para analisar minutas de contrato, ou participar da sua elaboração, é preciso que o Gerente conheça os prós e contras dos principais tipos de contratos, permitindo-lhe atuar de forma diferenciada, com observância das matizes de cada arranjo.

O PMI (2004) considera que a maioria dos contratos enquadra-se em três grandes categorias: por preço fixo ou global ("fixed price" ou "lump sum”), por custos reembolsáveis ("cost reimbursable") e por tempo e material ("time and material").

No Brasil, a Lei n. 8.666/93 dispõe, no seu art. 10, que as obras e serviços poderão ser executados nas formas de execução direta ou de execução indireta, admitindo quatro regimes para esta última: empreitada por preço global, empreitada por preço unitário, tarefa e empreitada integral.

Neste trabalho, para um melhor exame das características dos principais arranjos possíveis, os contratos foram divididos em categorias, levando em conta a forma de atuação da parte contratada, a abrangência do objeto a ser executado e a forma de remuneração do contrato. Essa categorização e a análise das suas características foram feitas com base na Lei n. 8.666/93 e suas alterações complementares, e em Bramble (1990); Collier (1987); Dinsmore e Cavalieri (2005); FIDIC (1999); Harris e McCaffer (1999); Institution of Civil Engineers (1991); Kertzner (2006b); McConville (1993); PMI (2004).

$\mathrm{Na}$ discussão das características de tipos de contratos, é importante sempre levar em conta que o contrato entre comprador e vendedor forma-se de proposta oferecida pelo vendedor, a qual, por sua vez, foi preparada com base nas exigências originalmente estabelecidas no edital ou cartaconvite elaborada pelo comprador.

\section{a) Quanto à forma de atuação da parte contratada.}

Destacam-se duas espécies: atuação isolada, quando a contratada é responsável isoladamente por todas as obrigações contratuais; e atuação em consórcio, quando as empresas 
que o integram têm responsabilidade solidária pelas obrigações assumidas em contrato. Os consórcios podem ser classificados em verticais ou horizontais, dependendo das características das empresas integrantes, dos serviços contratados e das condicionantes específicas estabelecidas no contrato.

No consórcio horizontal, as empresas integrantes executam em conjunto todas as obrigações contratuais. As potencialidades deste tipo de consórcio são: menor custo de administração; possível redução do investimento; possível ganho com fornecedores; e maior controle do cronograma contratual. Dentre as limitações, sobressaem a falta de padronização e a dificuldade de controle das atividades.

No consórcio vertical, o objeto do contrato é dividido em partes. Cada empresa integrante do consórcio executa uma parte dos serviços, ou fornece parte dos componentes constantes do contrato, em função de suas especializações e/ou das definições contidas no documento de constituição do consórcio. A principal potencialidade desta modalidade de consórcio é a manutenção da cultura empresarial de cada empresa que o integra. As principais limitações são: aumento do custo de administração, possível variação na qualidade dos serviços e variação nos prazos de execução dos serviços.

b) Quanto à abrangência do objeto a ser executado.

Comentam-se a seguir os aspectos básicos de algumas modalidades de contratos, classificados em função do objeto abarcado, e as respectivas denominações correntes no mercado da construção pesada, às vezes acompanhadas das correspondentes expressões em inglês.

Construção (“Construction”). Pode envolver apenas construção civil, ou construção civil e montagem de componentes eletromecânicos. Os serviços de elaboração do projeto básico e/ou executivo e serviços correlatos $^{14}$, tais como sondagens, ensaios e testes de laboratório, assim como o fornecimento dos componentes eletromecânicos, ficam sob a responsabilidade da parte Contratante.

Engenharia e Construção ("Design and Build - DB"). Além dos serviços de elaboração dos projetos básico e executivo, da construção civil e da montagem eletromecânica, a parte contratada também é responsável pelo anteprojeto de engenharia.

14 Às vezes denominados "serviços de engenharia". 
Engenharia, Suprimento e Construção ("Engineering, Procurement and Construction EPC'). A contratada assume responsabilidade integral e desenvolve toda a cadeia de implantação do empreendimento, desde o projeto básico até a entrega do empreendimento à contratante, pronto para operar (“Turnkey”). Exige condições especiais de contratação e de garantias de execução, e um cuidado muito grande na definição das regras operacionais a serem seguidas.

Gerenciamento ("Project Management - PM"). A contratada atua como agente da contratante ao longo da execução do contrato, no planejamento da contratação, seleção e contratação dos serviços de engenharia, suprimento e construção. A remuneração da contratada varia conforme o nível do seu envolvimento direto nos serviços e o grau de transferência dos riscos associados à implantação do empreendimento.

\section{c) Quanto à forma de remuneração e abrangência do objeto do contrato.}

Comentam-se a seguir os regimes de execução mais utilizados. Os Quadros 2.1, 2.2 e 2.3 apresentam as principais características dos regimes de preço global, preço unitário e administração, examinadas dos pontos de vista de reforço e de restrição ao uso de cada um.

Empreitada Integral. "Quando se contrata um empreendimento em sua integralidade, compreendendo todas as etapas das obras, serviços e instalações necessárias, sob inteira responsabilidade da contratada até a sua entrega ao contratante em condições de entrada em operação [...]" (Lei n. 8.666/93, art. 6, alínea "e" do inciso VIII). No caso da Contratante ser entidade ou órgão público, no escopo da Contratada não pode figurar a elaboração do projeto básico, pois a existência deste constitui requisito indispensável à realização da licitação ${ }^{15}$.

No caso da Contratante ser empresa privada e, portanto, não sujeita à Lei n. 8.666/93, este regime de execução, quando também incluir a elaboração do projeto básico pela Contratada, costuma ser denominado de "Turnkey" ${ }^{16}$ e de "EPC Turnkey".

Preço Global (“Lump Sum”). O objeto é contratado por um valor total, e os serviços são remunerados por etapa alcançada. O risco maior é da parte Contratada, que é responsável pelo

\footnotetext{
15 Lei n. 8.666/93, art. 14 .

16 Caruth e Stovall assim definem a expressão turnkey: "pertencente a projeto ou sistema que pode ser usado imediatamente sem outras compras ou arranjos (Refere-se a um automóvel em que você simplesmente gira a chave e sai dirigindo)". (1995, p. 308, tradução nossa).
} 
preço e pelos quantitativos dos serviços (Collier, 1987; PMI, 2004). Exige completa e detalhada especificação técnica do objeto do contrato. No Brasil, este regime é admitido na legislação vigente (Lei n. 8.666/93, art. 10, alínea “a” do inciso II), sendo utilizado na maioria das licitações e contratações de projetos do setor da construção pesada, promovidos tanto pelo Poder Público como pela iniciativa privada.

\begin{tabular}{l|l}
\hline \multicolumn{1}{c|}{ Potencialidades } & \multicolumn{1}{c}{ Limitações } \\
\hline $\begin{array}{l}\text { Minimiza o acompanhamento do contrato } \\
\text { pela contratante }\end{array}$ & $\begin{array}{l}\text { Favorece alterações contratuais pela } \\
\text { contratante }\end{array}$ \\
$\begin{array}{l}\text { Tende a predispor favoravelmente a } \\
\text { contratante à execução do } \\
\text { empreendimento }\end{array}$ & $\begin{array}{l}\text { Favorece a perda da qualidade pela } \\
\text { contratada, em favor da redução dos } \\
\text { custos }\end{array}$ \\
& $\begin{array}{l}\text { Induz a contratante à solução de } \\
\text { controvérsias por arbitragem }\end{array}$ \\
\hline
\end{tabular}

FONTE: Adaptado pelo autor a partir de Collier (1987); FIDIC (1999); Harris e McCaffer (1999); PMI (2004).

Quadro 2.1 - Aspectos do regime de preço global.

Metas ou alvos (“Target”). Regime às vezes também denominado de Aliança ("Alliance”). Utilizado nos casos de contratação direta pela Contratante. As partes elaboram em conjunto o orçamento que determina o preço de venda do empreendimento, bem como o prazo e/ou o valor de algumas parcelas (alvos) a serem acompanhados, vinculando a elas condições especiais de remuneração (cláusulas de ônus e bônus). Os alvos podem ser somente de preço, ou de prazo, ou de preço e prazo.

Possibilita equilíbrio entre prazo, qualidade e custo, sem transferir integralmente os riscos à contratada, bem como incentiva a melhoria do desempenho geral da contratada. Todavia, não assegura à contratante o custo final do empreendimento. No Brasil, a legislação vigente aplicável ao setor público não contempla este regime de execução.

Preço Unitário (“Unit Price”). Utilizado quando o objeto do contrato é bem conhecido, mas há indefinições nas quantidades de serviços. A contratada não é responsável pelos quantitativos. O risco tende a ser desfavorável à contratante (Collier, 1987). A remuneração é obtida pela multiplicação das quantidades executadas de cada serviço, pelo seu respectivo preço unitário. 
Regime admitido expressamente pela legislação brasileira vigente (Lei n. 8.666/93, art. 10, alínea "b" do inciso II).

\begin{tabular}{l|l}
\hline \multicolumn{1}{c|}{ Potencialidades } & \multicolumn{1}{c}{ Limitações } \\
\hline $\begin{array}{l}\text { Flexibilidade de atuação entre as partes } \\
\text { contratante e contratada }\end{array}$ & $\begin{array}{l}\text { Não há incentivo financeiro para a redução } \\
\text { de prazos e do custo total do projeto }\end{array}$ \\
Permite início e término rápidos & $\begin{array}{l}\text { Não garante necessariamente a qualidade } \\
\text { dos serviços executados }\end{array}$ \\
Há facilidade de acompanhamento & \\
\hline
\end{tabular}

FONTE: Adaptado pelo autor, a partir de Collier (1987); Harris e McCaffer (1999).

Quadro 2.2 - Aspectos do regime de preço unitário.

Administração ("Cost-plus-fixed-fee"). Regime utilizado quando o objeto do contrato encontra-se caracterizado, mas os serviços que o compõem são de difícil quantificação. O risco é quase todo da parte contratante, que arca com todos os gastos. A contratada é remunerada pela aplicação de uma taxa incidente sobre todos os gastos necessários ao cumprimento do contrato. A remuneração pode se dar direta ou indiretamente, por reembolso. No Brasil, a legislação em vigor vetou ${ }^{17}$ este regime para as contratações feitas por entidades do setor público.

\begin{tabular}{l|l}
\hline \multicolumn{1}{c|}{ Potencialidades } & \multicolumn{1}{c}{ Limitações } \\
\hline $\begin{array}{l}\text { Permite o máximo de flexibilidade entre as } \\
\text { partes }\end{array}$ & Não assegura o custo final \\
Minimiza conflitos futuros & $\begin{array}{l}\text { Exige constante controle da parte } \\
\text { contratante }\end{array}$ \\
$\begin{array}{l}\text { Permite à contratante selecionar e } \\
\text { contratar com a empresa melhor } \\
\text { qualificada }\end{array}$ & $\begin{array}{l}\text { Não incentiva a minimização de prazos e } \\
\text { custos }\end{array}$ \\
\hline
\end{tabular}

FONTE: Adaptado pelo autor, a partir de Collier (1987); Harris e McCaffer (1999).

Quadro 2.3 - Aspectos do regime de administração.

17 Lei n. 8.666/93, art. 60, alínea "c" do inciso VIII, e art. 10, alínea "c" do inciso II, com a redação dada pela Lei n. 8.883/94. 
Memoriais, desenhos, especificações e normas técnicas constituem o ponto de partida do Gerente para estruturar um contrato de empreendimento de construção pesada, e também para analisar um contrato preparado por terceiros. É importante ressaltar que a qualidade dos documentos técnicos citados tem influência direta na estruturação ou na análise efetuada.

"Dar forma ao contrato é tarefa do advogado. Este, porém, tem que estar sensível ao que os outros técnicos pretendem. Caso contrário, irá redigir um contrato divorciado da realidade e que não irá atingir os objetivos desejados", afirma Amaral (2006a, p. 214). Segundo Rojas e Maldonado (2003), a redação de um contrato exige de quem o faz:

- Seguir uma ordem lógica;

- Ser claro e preciso;

- Preservação do equilíbrio entre as partes;

- Sagacidade e previsão; e

- Coerência.

Redigir [...] significa etimologicamente "compilar, por em ordem", sendo sua acepção mais comum a de atividade consistente em "colocar por escrito coisas sucedidas, acordadas ou pensadas com anterioridade"; em outras palavras, redigir é um processo de recolher um conjunto de idéias ou de coisas que ocorreram ou foram ditas, trasladálas à linguagem escrita e colocá-las em uma ordem lógica, inteligível, da maneira mais clara e precisa possível.

[...] Redigir bem é pensar bem e, tratando-se de contratos, pensar bem significa ter conhecimento pleno do que pretendem as partes, traduzi-lo em termos jurídicos e fazêlo de forma inteligível no texto, não em termos técnicos, na medida do possível, mas em uma linguagem simples e clara, acessível aos leigos em Direito. (ROJAS e MALDONADO, 2003, p. 15 e 19, tradução do autor).

Os requisitos apontados anteriormente podem ser atendidos, mediante a formulação de perguntas, como as indicadas na Figura 2.2, cujas respostas permitem ao Gerente organizar o conteúdo do contrato em conjuntos de cláusulas, segundo uma ordem lógica de assuntos. As oito perguntas ali indicadas não exaurem o processo, devendo ser formuladas (e esgotadas) em cada caso concreto.

Estabelece-se, assim, um sumário estruturado do conteúdo do contrato, facilitando a análise da precisão, equilíbrio, previsão e coerência do conjunto das cláusulas que o integram. 
O exemplo seguinte foi elaborado com utilização de algumas das cláusulas mais freqüentes nos contratos do setor da construção pesada, procurando melhor ilustrar o que foi afirmado anteriormente.

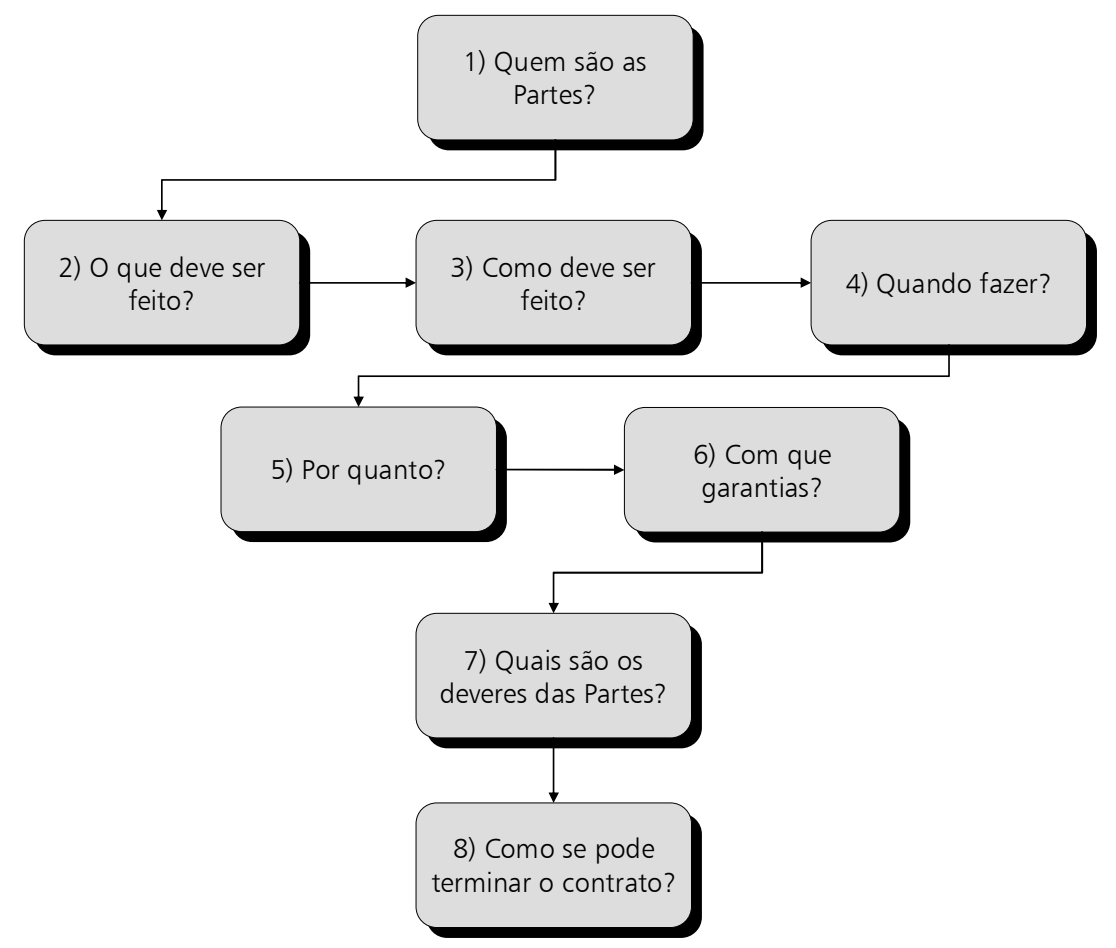

FONTE: Elaborado pelo autor, com posterior adaptação a partir de Rojas e Maldonado (2003).

Figura 2.2 - Como o contrato pode ser formado ou analisado.

1) Cláusula típica que pode ser agrupada sob a pergunta "Quem são as Partes?” - As partes, identificadas e qualificadas.

2) Cláusulas típicas que podem ser agrupadas sob a pergunta "O que deve ser feito?" - Objeto;

- Local de execução do objeto;

- Autorizações necessárias à execução do objeto;

- Relação dos documentos anexados ao contrato, integrando-o ${ }^{18}$;

- Ordem de prevalência entre o contrato e os documentos que lhe são anexos;

- Definições de termos técnicos e expressões;

18 Os documentos integrantes do contrato, como se nele estivessem transcritos, efetivamente caracterizam o seu objeto. Nos empreendimentos de infra-estrutura tratados neste trabalho, a descrição sucinta do objeto, contida em cláusula (ou cláusulas) que levam o seu nome, não é suficiente para caracterizá-lo. 
- Idioma do contrato;

- Legislação aplicável.

3) Cláusulas típicas que podem ser agrupadas sob a pergunta "Como deve ser feito?"

- Regime de execução do contrato;

- Especificações e normas técnicas aplicáveis;

- Qualidade;

- Meio ambiente;

- Procedimentos de Segurança e Medicina do Trabalho;

- Fiscalização;

- Condições e limites de subcontratações;

- Condições de operação inicial;

- Condições dos recebimentos provisório e definitivo do objeto.

4) Cláusulas típicas que podem ser agrupadas sob a pergunta "Quando fazer?"

- Prazo de execução do objeto e vigência do contrato;

- Datas-marco;

- Prazo de extinção do contrato;

- Cronograma físico de execução.

5) Cláusulas típicas que podem ser agrupadas sob a pergunta "Por quanto?"

- Preço;

- Impostos e tributos incidentes;

- Forma de medição e emissão de documentos de cobrança;

- Condições de pagamento;

- Reajustamento de preços;

- Ajuste financeiro pelo prazo de pagamento;

- Atualização monetária por atraso de pagamento.

6) Cláusulas típicas que podem ser agrupadas sob a pergunta "Com que garantias?" - Seguros;

- Garantia de execução do contrato ("Performance bond”);

- Multas e penalidades;

- Danos acordados; 
- Garantia técnica do objeto.

7) Cláusulas típicas que podem ser agrupadas sob a pergunta "Quais são os deveres das partes?"

- Obrigações comuns às partes;

- Obrigações da contratante;

- Obrigações da contratada;

- Responsabilidades de cada parte;

- Interferências da parte contratante;

- Comunicação entre as partes.

8) Cláusulas típicas que podem ser agrupadas sob a pergunta "Como se pode terminar o contrato?"

- Suspensão dos serviços;

- Rescisão;

- Força maior - definição, conseqüências e comunicação;

- Processos de solução de disputas e controvérsias;

- Foro.

\section{$2.4 \quad$ NEGOCIANDO CONTRATOS}

Para o Gerente, a negociação significa a condução de conversações, com a finalidade de resolver um problema. Sempre que as pessoas trocam idéias com a intenção de alterar relacionamentos, sempre que deliberam sobre um acordo, estão negociando, diz Nierenberg (1986).

A negociação é a etapa do processo de contratação em que as partes buscam a convergência dos seus interesses. A atividade exige que o negociador tenha um conhecimento abrangente do contrato (aspectos técnicos de engenharia, jurídicos, administrativos e econômico-financeiros), conjugado ao domínio da comunicação, em que predomina, sobretudo, a percepção e a habilidade de inter-relacionamento pessoal.

Saber negociar significa aliar ao conhecimento do assunto em questão, a competência para negociar, em que influem a pessoa, a situação e o processo de negociação (Junqueira, 1987). Em 
projetos de construção pesada, o edital, a proposta e o contrato constituem as fontes do conhecimento mencionado, proporcionando ao Gerente o domínio do assunto e permitindo-lhe o estabelecimento dos seus limites na negociação, como retratado na Figura 2.3.

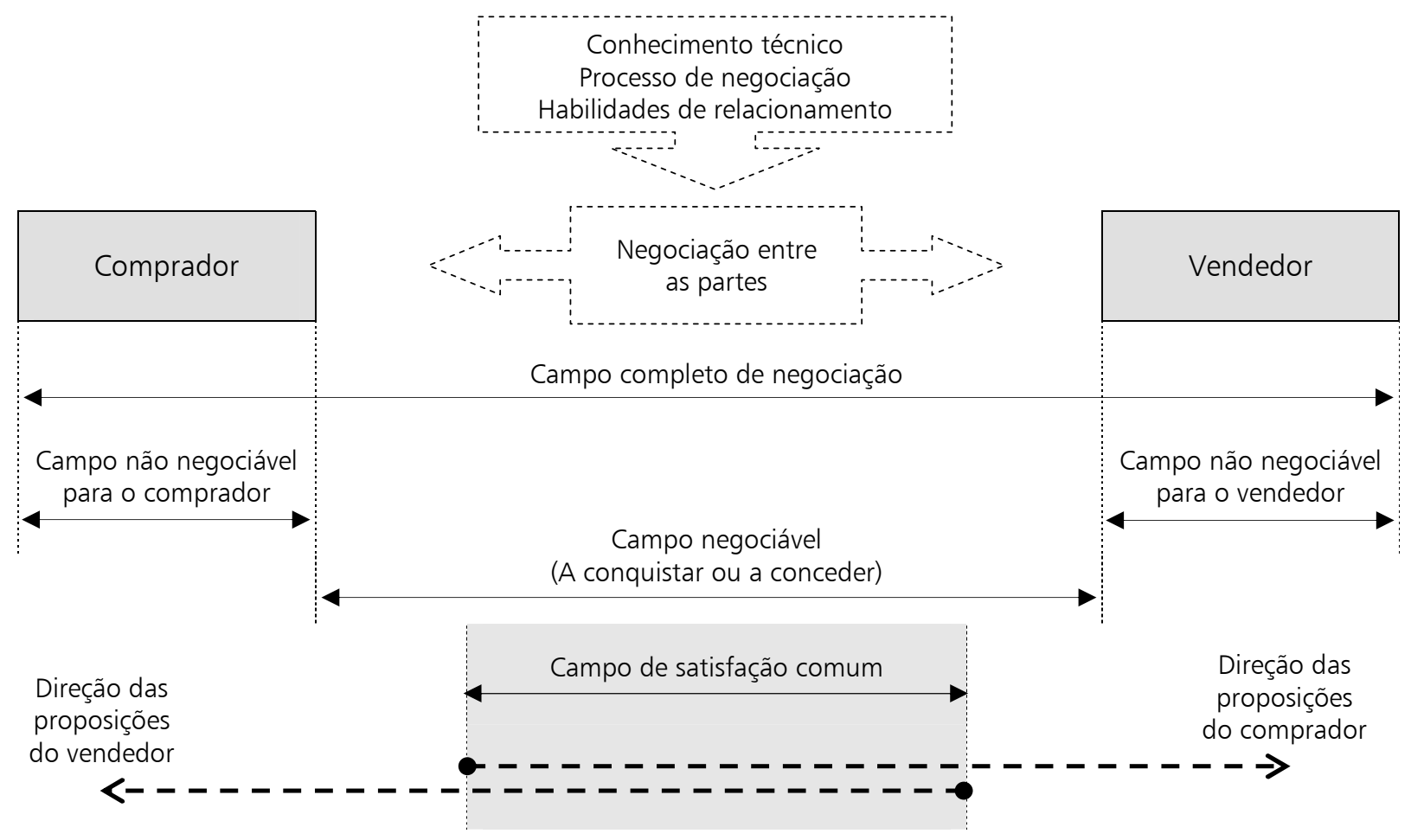

FONTE: Adaptado pelo autor a partir de Daemon et al. (1982).

Figura 2.3 - O cenário da negociação.

O pressuposto básico da negociação é o de que as partes necessitam de relacionamento continuado. Trata-se, portanto, de um processo em que as necessidades e objetivos das duas partes devem ser satisfeitas, sendo importante o preparo cuidadoso de estratégias de concessão. Fisher et al. (1994) recomendam que numa negociação sejam adotados os seguintes princípios básicos:

- Discutir a questão, não as pessoas envolvidas;

- Estudar alternativas antes de tomar decisões;

- Primeiro estabelecer critérios, depois discutir números.

Diversos autores, entre os quais Junqueira (1987); Matos (1985); Nieremberg (1986); Sparks (1986); Stark (1999) apontam a negociação como um processo contínuo, obedecendo a uma seqüência certa e determinada de fases que não podem ser invertidas. De uma maneira geral, 
esses autores concordam que o desenvolvimento ideal de uma negociação se dá na seguinte ordem das referidas fases: (a) planejamento, (b) abertura, (c) investigação, (d) persuasão e alternativas, e (e) concessões e acordo. Em cada uma dessas fases, o processo de negociação é basicamente afetado por três variáveis: informação, tempo e poder.

\section{a) Fase de planejamento.}

A fase interna do processo, em que a outra parte ainda não está presente. As principais etapas desta fase são as seguintes:

- Identificação dos integrantes da equipe de negociação e definição dos papéis e atitudes que se espera que cada integrante da equipe assuma;

- Avaliação da situação, definindo-se: (i) objetivos de curto, médio e longo prazos, (ii) prioridades, valores e riscos envolvidos, (iii) limites de autoridade dos integrantes da equipe de negociação, e (iv) presunção das necessidades da outra parte (objetivos, estrutura organizacional, posição e poder de decisão, estilo de negociação);

- Estudo de alternativas, compreendendo: (i) diagnóstico sobre o que pode mudar, (ii) identificação de fatos indesejáveis, comparados com a situação desejável, (iii) classificação dos sintomas e sugestão das causas, (iv) avaliação das possíveis soluções, e (v) ações específicas que podem ser adotadas para implantar a alternativa;

- Definição das estratégias de negociação: (i) atribuições e papel dos integrantes da equipe de negociação, (ii) visitas e contatos pré-negociação, (iii) estilo de negociação a adotar, (iv) argumentos e documentação de apoio, $(v)$ relação dos fatos a serem confirmados durante a negociação, (vi) estudo das margens de concessão, (vii) elaboração de agenda ou roteiro, e (viii) avaliação e adequação do local da negociação (arranjo, apoio e comodidades).

\section{b) Fase de abertura da negociação.}

Esta etapa dá início à negociação propriamente dita entre as partes, destinando-se a criar um clima propício ao acordo. Trata-se de uma sondagem inicial, com assuntos não relacionados diretamente à negociação, tais como: apresentações, amenidades e declaração à outra parte do firme propósito de chegar a um acordo que atenda ao interesse de ambas as partes. 


\section{c) Fase de investigação.}

Etapa cujo objetivo é detectar necessidades, expectativas e motivações, consistindo na troca de informações diretamente relacionadas com a negociação. Aqui são apresentados dados que devem ser confirmados pela outra parte, e são feitas perguntas adrede preparadas na etapa de planejamento, tais como: preço e forma de pagamento, forma de reajustamento do preço, prazos e locais de entrega, quantidades, qualidade, garantias, compromissos futuros, e outros tópicos.

\section{d) Fase de persuasão e alternativas.}

Nesta etapa, uma das partes finalmente esclarece à outra a proposição apresentada, descrevendo as soluções adotadas e indicando os benefícios mútuos que serão acarretados. Seguem-se alguns dos pontos a serem observados: ( $($ ) não se deve presumir nada: o que é importante para uma das partes pode não ser importante para a outra; (ii) todas as dúvidas devem ser esclarecidas: em se tratando de pontos essenciais, o esclarecimento deve ser dado, mesmo que não seja perguntado; (iii) alternativas estudadas na etapa de planejamento devem ser induzidas; e (iv) alternativas propostas pela outra parte não devem ser aceitas sem a reavaliação do risco.

\section{e) Fase de concessões e acordo.}

O acordo equilibrado e satisfatório para as partes deve ocorrer nesta fase, desde que as fases anteriores sejam adequadamente cumpridas. Vale lembrar que não se deve fazer concessão que não foi solicitada e que concessões só devem ser feitas, desde que previamente analisadas e avaliadas. 


\title{
3 ASPECTOS DA ADMINISTRAÇÃO DE CONTRATO
}

É parte do provável que aconteça o improvável.

(Daniel Myerson)

\subsection{PRINCÍPIOS DA ADMINISTRAÇÃO CONTRATUAL}

Na terceira e mais recente edição do seu Guia PMBOK, o Project Management Institute assim define Administração de Contrato:

\begin{abstract}
O processo de gerenciamento do contrato e da relação entre o comprador e o fornecedor, análise e documentação do desempenho atual ou passado de um fornecedor a fim de estabelecer ações corretivas necessárias e fornecer uma base para futuras relações com o fornecedor e gerenciamento de mudanças relacionadas ao contrato e, quando adequado, gerenciamento da relação contratual com o comprador externo do projeto. (PMI, 2004, p. 351).
\end{abstract}

Ainda segundo o PMI, “o processo Administração de Contrato garante que o desempenho do fornecedor atende aos requisitos contratuais e que o comprador atue de acordo com os termos do contrato" (2004, p. 290). Garret defende idéia semelhante, afirmando que o objetivo da Administração de Contrato é assegurar a conformidade dos termos e condições contratuais, ao longo da execução do contrato e até o seu encerramento [S.I.:s.n., ca. 2000].

Considerando esse objetivo, e não obstante a provável ocorrência de fatos imprevistos e imprevisíveis ao longo da execução do contrato, o Gerente da parte contratada atua para assegurar que o resultado econômico-financeiro do contrato se verifique, na medida da sua expectativa original. Para isso, é necessário que a parte contratada:

- Cumpra com as obrigações ${ }^{19}$ assumidas em contrato, bem como exija da parte contratante o cumprimento das suas;

19 De acordo com o Dicionário Técnico Jurídico - Deocleciano Torrieri Guimarães (São Paulo: Rideel, 1995), obrigação é a "vinculação jurídica entre duas ou mais pessoas que consiste no dever de dar, fazer, ou abster-se de fazer algo em proveito de outrem, de ordem econômica ou moral", e responsabilidade é o "dever jurídico a todos imposto de responder por ação ou omissão imputável que signifique lesão ao direito de outrem, protegido por lei". O descumprimento de obrigação contratual gera multa; o descumprimento de responsabilidade gera indenização do prejuízo causado. 
- Exija o cumprimento das obrigações dos seus fornecedores subcontratados, bem como cumpra as assumidas com eles;

- Solucione eventuais conflitos ${ }^{20}$, o mais rapidamente possível, evitando que o contrato sofra solução de continuidade.

"Contratos incluem uma oferta e uma aceitação", diz Kertzner (2006b, p. 245, tradução nossa). E prossegue: "A oferta é uma resposta a uma necessidade, e a aceitação é baseada nos detalhes específicos da oferta". O ciclo de vida da Administração de Contrato tem o seu começo fixado pela assinatura do contrato entre as partes (CAVENDISH e MARTIN, 1997). O processo está inteiramente vinculado ao contrato celebrado ("contrato principal"), que se desdobra em uma série de acordos acessórios, como mostra a Figura 3.1.

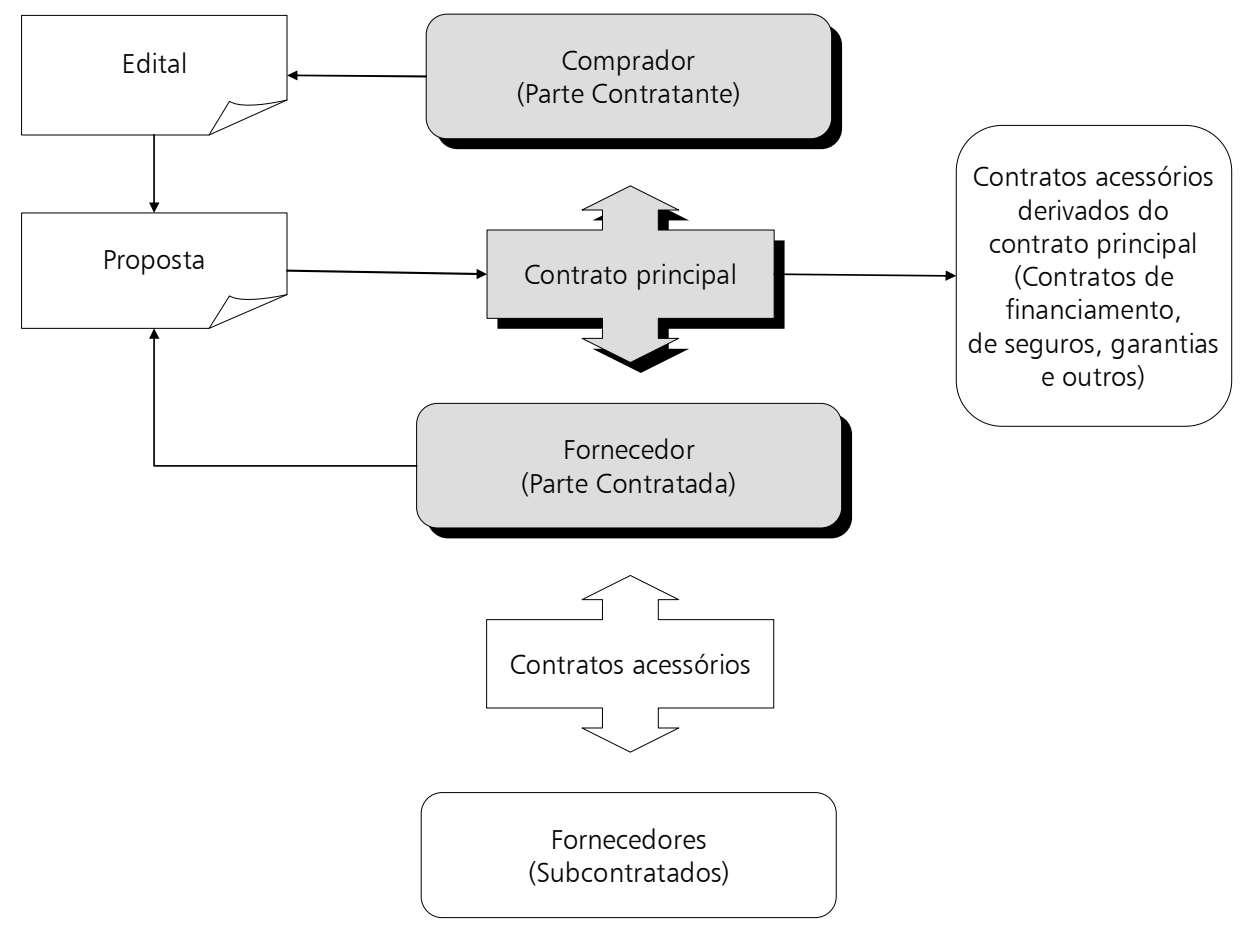

FONTE: Elaborado pelo autor.

Figura 3.1 - Alcance da administração contratual.

No dia-a-dia da execução do contrato, o Gerente, quer seja ele o representante da parte contratante, quer da contratada, deve sempre questionar: (i) se um acontecimento foi ou não previsto, e se a sua ocorrência pode, ou poderá, ameaçar as expectativas dos interessados no empreendimento; e (ii) se tal acontecimento é, ou será, exclusivamente uma ameaça ou se comporta desdobramentos favoráveis.

20 Os conceitos associados ao gerenciamento de riscos serão abordados no Capítulo 4 deste trabalho. 
Amaral (2006a, p. 221) ressalta o cuidado que se deve ter no procedimento de qualquer alteração contratual, destacando: “(a) não se pode desfigurar o contrato, executando-se algo que não se inclua no objeto contratual; (b) as extensões contratuais devem ser solidamente justificadas, independentemente do seu valor; (c) as alterações devem ser autorizadas por quem seja competente para fazê-lo".

Realizada a contratação, para estabelecer um programa de Administração de Contrato interessam ao Gerente, em especial, as informações provenientes da análise e interpretação das seguintes fontes: contrato celebrado entre as partes Contratante e Contratada; as etapas do caminho crítico da execução do empreendimento; as obrigações recíprocas assumidas em contratos com os principais fornecedores ("subcontratados"); os esclarecimentos prestados pela Contratante durante a licitação; e as qualificações e condicionamentos constantes da proposta apresentada à Contratante, bem como aqueles resultantes de negociação para assinatura do contrato. No Capítulo 4 deste trabalho, procura-se mostrar o momento e a forma de obtenção das qualificações e condicionamentos feitos.

O instrumento do contrato e os documentos que lhe são anexos, constituem a referência para a prática da Administração de Contrato. É indispensável que todos os integrantes da equipe de gerenciamento do projeto tenham o melhor e mais detalhado conhecimento possível sobre esses documentos.

Contratos de construção estão repletos de riscos potenciais para a empreiteira. [...] É
essencial que os riscos contratuais também sejam entendidos no contexto da decisão de
ofertar-se ou não uma proposta. [...] O gerente de projeto é o tempo todo um gestor de
riscos. Ele é também um gerente de contrato - cumprindo com suas obrigações e
garantindo que as outras partes cumpram seus deveres. Todas as empreiteiras deveriam
colocar um aviso nos seus escritórios, com as palavras: "Leia o contrato". (FRISBY,
1990, p. 120-121, tradução do autor).

O PMI afirma que "a Administração de Contrato inclui a aplicação dos processos de gerenciamento de projetos adequados à(s) relação(ões) contratual(is) e a integração das saídas desses processos ao gerenciamento geral do projeto" (2004, p. 290). Entre outros processos de gerenciamento citados pelo PMI, destacam-se:

- O monitoramento dos custos, do cronograma e do desempenho técnico da Contratada;

- A inspeção e verificação da qualidade do produto da Contratada; 
- O controle integrado de mudanças, "para garantir que as mudanças sejam aprovadas corretamente e que todas as pessoas que precisam conhecê-las estejam cientes dessas mudanças” (PMI, 2004, p. 291);

- Monitoramento de riscos, visando sua mitigação.

A abordagem anterior permite concluir que o processo de administração contratual exige trabalho coletivo, isto é, o esforço de todos os integrantes da equipe de gerenciamento do Projeto, sendo especialmente afetado por dois fatores interdependentes, cuja combinação o condiciona e dirige: (i) legislação, doutrina e jurisprudência que disciplina a matéria e a execução de empreendimentos, e (ii) a cultura ${ }^{21}$ do ambiente onde o projeto é executado.

O gestor do contrato é responsável pela consecução dos objetivos que nortearam a contratação. Disso resulta que:

a) deve ele não apenas articular-se com o pessoal da outra parte, mas também articular as áreas internas envolvidas no contrato;

b) as áreas internas envolvidas devem prestar-lhe todo o apoio administrativo, técnico e jurídico que lhes seja solicitado.

A articulação interna deve ser efetuada, sempre que possível, informalmente. Esclarecimentos devem ser solicitados, em regra, verbalmente, e também verbalmente prestados. Há que presidir, nesses entendimentos, a confiança mútua. Ninguém tem o direito de pedir ou prestar esclarecimentos com o objetivo de embaraçar seu interlocutor. A boa execução do contrato é um benefício para ambas as partes e somente pode ser obtida com uma adequada gestão, dependente não só da boa coordenação pelo seu principal responsável, como também da qualidade e presteza do apoio administrativo, comercial, técnico e jurídico que lhe seja prestado.

O gestor do contrato, porém, deve aparelhar-se, tanto quanto possível, para reduzir as dúvidas e, portanto, o número de oportunidades em que precise recorrer às demais áreas. A capacidade de decisão própria, sem necessidade de informações, esclarecimentos ou pareceres, tem que ser desenvolvida ao máximo. A par disso, é necessário discernir ainda, e muito bem, quando é necessário recorrer a uma dessas áreas, em busca de respaldo a uma decisão, e quando a decisão pode e deve ser tomada de imediato, sem consulta. As duas preocupações estão interligadas e se reduzem a uma única: aperfeiçoamento profissional.

Já a articulação externa deve, em regra, ser traduzida em documentos escritos, especialmente quando o contrato ou a lei assim o prevejam. (AMARAL, 2006a, p. 221222).

As atividades constantes do processo de administração contratual são as seguintes, segundo Guilherme Radel e Alexandre de Carvalho apud Amaral (2006a): (a) planejamento, (b) controle, (c) diligenciamento e coordenação de interfaces, (d) informação, e (e) registro.

21 O termo cultura é aqui empregado com o significado que lhe é dado pelo Dicionário HOUAISS (2001): “conjunto de padrões de comportamento, crenças, conhecimentos, costumes etc que distinguem um grupo social”. 


\section{a) Planejamento.}

Atividade desenvolvida primeiramente nas fases de licitação e contratação do Projeto, consistindo na análise crítica da minuta do contrato e das especificações técnicas do empreendimento. Depois, num segundo momento, logo após a assinatura do instrumento de contrato pelas partes, funda-se então na re-análise crítica dos documentos contratuais.

\section{b) Controle.}

"Desde que a prevenção da mudança não seja possível, a melhor esperança para o Gerente de Projetos parece estar em controlar o processo pelo qual a mudança é introduzida e alcançada" (MEREDITH e MANTEL JR., 2003, p. 351).

Atividade que compreende o conhecimento e acompanhamento das obrigações assumidas e dos direitos decorrentes do contrato assinado entre as partes, bem como das obrigações e direitos gerados por acordos acessórios, tais como os celebrados junto a fornecedores, prestadores de serviços e instituições seguradoras. Visa ao alerta antecipado a respeito dessas obrigações e direitos, para serem atendidos na forma e no prazo pactuados. "(O) controle deve, inclusive, estender-se aos subcontratos, apesar de não existir relação jurídica entre subcontratada e contratante" (Amaral, 2006a, p. 221).

\section{c) Diligenciamento e coordenação de interfaces.}

O termo "diligenciar" é empregado, no contexto deste trabalho, com a acepção de “esforçar-se por; empregar os meios para; empenhar-se por". Trata-se de acionar, para que as coisas aconteçam. Coordenar interfaces significa promover a integração dos diversos processos de gerenciamento necessários à execução do Projeto. Algumas interfaces são reguladas de forma explícita no contrato principal e nos contratos que lhe são assessórios; outras necessitam ser detectadas e tratadas.

\section{d) Informação.}

Atividade de gestão da informação, compreendendo especialmente: fluxo, espécie e forma do seu fornecimento, quer a informação de caráter obrigatório, quer a proveniente de solicitações 
pontuais, endereçadas (i) às partes, (ii) à equipe interna de cada uma das partes, (iii) a terceiros subcontratados, e (iv) a interessados externos ao empreendimento.

\section{e) Registro.}

Registro, documentação e arquivo de informações sobre fatos relevantes, ocorridos durante a execução do contrato ou nele influentes, notadamente os relativos a alterações contratuais. Na Administração de Contrato, a comunicação escrita inclui, dentre outros meios, atas de reunião, cartas e relatórios. Cleland e Ireland (2004, p. 452-453) dizem que para atingir a melhor comunicação escrita, os integrantes da equipe de gestão do projeto devem elaborar mensagens simples, claras e diretas, e que, uma vez escrita a mensagem, convém revisá-la mediante o seguinte questionamento:

- A mensagem tem objetividade?

- Há lógica?

- Existem enganos na argumentação?

- A mensagem diz aquilo que pretende comunicar?

- Ela tem detalhes demais (ou insuficientes)?

- As regras gramaticais de pontuação, de formatação e de numeração empregadas na mensagem estão corretas?

Ao registro seguem-se ações visando assegurar direitos e até mesmo otimizar oportunidades, podendo levar à apresentação de reivindicações por qualquer uma das partes.

Quanto ao registro, é importante notar que ele tem duas funções básicas. Primeira, a de manter a memória da gestão do contrato, de maneira que não resulte grande prejuízo se houver substituição do gestor. Segunda, a de preservar direitos perante a outra parte. É lógico que um bom gestor de contratos não irá atormentar o pessoal da outra parte com interpelações ou notificações escritas. Mas não pode ele deixar de registrar por escrito - de preferência em uma ata de reunião ou em um relatório obrigatório, e só excepcionalmente em um documento específico - um fato que possa, amanhã, ser relevante provar. Registra e arquiva. (AMARAL, 2006a, p. 223).

\subsection{IMPORTÂNCIA DA INTERPRETAÇÃO DO CONTRATO}

Interpretação e estudo crítico contínuos do contrato são requisitos indispensáveis ao desenvolvimento do processo de Administração de Contrato. Conforme Liebing (1998), nenhum conjunto de documentos contratuais é perfeito, assim um sistema de interpretação e 
esclarecimento do significado pretendido dos documentos é muitas vezes útil, especialmente para evitar reivindicações.

Interpretar significa "ajuizar a intenção, o sentido de; explicar, explanar ou aclarar o sentido de (palavra, texto, lei, etc.)". Interpretando um dispositivo do contrato ou de documento que o integra, o Gerente busca determinar - do seu ponto de vista - o sentido real do que as partes acordaram. Segundo Frisby (1990), o ato de interpretar abrange primeiro a decisão sobre o significado das palavras; depois, a avaliação dos possíveis conflitos resultantes do entendimento adotado; e, por fim, um plano para enfrentamento e superação desses conflitos.

$\mathrm{Na}$ interpretação de contratos, os integrantes da equipe de gerenciamento devem observar preceitos, estando os mais gerais deles indicados no Quadro 3.1.

A interpretação deve:

- Ser razoável (no sentido de ser justa, legítima)

- Considerar o contrato e os documentos que o integram como um todo

- Levar em conta a ordem de precedência dos documentos contratuais

- Buscar a finalidade econômica do particular dispositivo que se está interpretando

- Assegurar que não há exigências legais contidas de forma implícita no tema da interpretação

- Investigar se há jurisprudência a respeito do tema da interpretação

FONTE: Adaptado de Frisby (1990, tradução do autor).

Quadro 3.1 - Preceitos de interpretação de contratos.

\subsection{ALTERAÇÕES CONTRATUAIS}

Durante a execução da maioria dos projetos de construção pesada provavelmente surgirão fatos novos, independentes da vontade do gerente e da intenção da proposta. Tais fatos alteram o contrato e podem acarretar o seu desequilíbrio econômico-financeiro, representando uma fonte de conflitos entre os principais agentes interessados no empreendimento. Originam-se de fatores os mais diversos, ensejando reivindicações: 
Ao longo do desenvolvimento de diferentes obras, é freqüente a ocorrência de eventos que modificam as condições pactuadas pelas partes na assinatura do contrato de empreitada.

As reivindicações surgem a partir da necessidade de renegociação dos contratos, com o fim de adequá-los a uma nova realidade fática. Em diversas situações, o Contratado se vê face a face com a necessidade de solicitar extensão de prazo ou compensação por custos adicionais ou ambos.

Em uma obra, por mais bem redigido e eqüitativo que seja o contrato, por melhor que sejam desenvolvidos os projetos e por mais explícitas que sejam as especificações, haverá motivos para se fazer reivindicações.

A reivindicação é ainda uma área nova de estudos e, sendo a construção civil um setor que se utiliza freqüentemente de contratos de longa duração, cada vez mais surge a preocupação por parte dos contratados e contratantes deste setor em saber como prevenir, identificar, elaborar, quantificar, apresentar e negociar uma reivindicação. (PEDROSA e ROCHA LIMA JR., 1994, p. 2).

Martin; Teagarden; Lambreth afirmam que "a alteração é inevitável, e a chave para o controle de custos passa a ser um sistema sadio para gerenciar a alteração quando ela ocorre” (1997, p. 267, tradução nossa). Surgindo o fato imprevisível, é um dever do Gerente se posicionar frente aos acontecimentos, visando garantir a continuidade da execução do Projeto (AMARAL, 2006a). Para poder atuar nesse sentido, fazendo com que o contrato seja cumprido, torna-se indispensável ao Gerente informar-se ${ }^{22}$ sobre aspectos fundamentais para a tomada de decisão, e que por isso precisam ser solidamente conceituados de um ponto de vista jurídico.

Os principais conceitos que devem ser conhecidos são: (a) as causas do desequilíbrio econômico e financeiro de um contrato; (b) os pressupostos para seu reequilíbrio; e (c) a necessidade de formalizar toda alteração contratual. O referencial jurídico apresentado a seguir foi transcrito de entrevista exclusiva sobre o assunto, constante do APÊNDICE E.

\section{a) Causas do desequilíbrio econômico e financeiro de um contrato.}

O desequilíbrio pode ser provocado por fatores internos ou externos ao contrato.

Os fatores internos são aqueles atribuíveis à contratante, tais como alteração de projeto e atraso na liberação de áreas, prevista no contrato.

Os fatores externos abrangem:

a) fato do príncipe, que é toda atuação estatal que repercute indiretamente no contrato, tais como aumento e redução de tributos, alteração de política cambial ou de política ambiental e intervenção nos preços (planos econômicos); e

b) os fatos incluídos na teoria da imprevisão, tais como surto inflacionário, sujeições imprevistas, força maior (greve abusiva, incêndio provocado por terceiros) e caso fortuito (chuvas inesperadas, índice pluviométrico anormal). (AMARAL, 2006b).

22 Não só informar-se, mas também divulgar essas informações aos integrantes da equipe de gerenciamento da qual é o líder. 


\section{b) Pressupostos para o reequilíbrio de um contrato.}

Para que surja o direito ao reequilíbrio do contrato (e correspondente dever da outra parte de reequilibrar o contrato) é necessário que o fato que provocou o desequilíbrio tenha sido imprevisível (ou previsível mas de conseqüências incalculáveis) e se contenha na álea extraordinária do negócio.

Não existe critério objetivo para distinguir álea ordinária e álea extraordinária. A questão deve ser analisada caso a caso.

Assim, tanto nos contratos de direito privado, quanto nos contratos administrativos, ocorrido o desequilíbrio econômico-financeiro por fato superveniente e imprevisível contido na "álea ou risco extraordinário", deve proceder-se a seu reequilíbrio. O que difere é o fundamento jurídico-conceitual invocado. Nos contratos administrativos, a teoria da imprevisão. Nos contratos de direito privado, a teoria da base do negócio.

Há, porém, uma relevante distinção teórica, de conseqüências práticas. Nos contratos de direito privado, é necessário que a onerosidade seja "excessiva", de acordo com o Código Civil (art. 478). Nos contratos administrativos, essa excessividade não é exigida, já que a Constituição determina que sejam mantidas as condições iniciais da proposta (art. 37, XXI).

O conceito de "onerosidade excessiva" deve ser determinado em cada caso concreto e essa determinação tem um alto grau de subjetividade. Assim como ocorre com o conceito de "álea ou risco extraordinário".

Por último: o reequilíbrio é uma via de duas mãos. Se em regra o desequilíbrio ocorre em desfavor da contratada, há casos em que ocorre em desfavor da contratante. $O$ dever de reequilibrar o contrato existe em ambas as hipóteses. (AMARAL, 2006b).

\section{c) Necessidade de formalizar toda alteração contratual.}

Toda alteração contratual deve ser formalizada por um aditivo. Nos contratos de direito privado, esse aditivo pode ser uma simples ata, um registro no diário de obras, ou uma troca de correspondências. Nos contratos administrativos, a alteração deve ser formalizada mediante instrumento próprio.

Nos contratos administrativos, é comum alegar-se que a alteração de quantitativos pode ensejar o chamado "jogo de planilha" 23. Mas não se podem estabelecer regras de administração de contratos a partir de situações patológicas. Seria irrealismo esperar que um projeto básico, por mais bem elaborado que seja, contemple com exatidão os quantitativos estimados para cada item da planilha. Ainda que a licitação seja precedida de um excelente projeto executivo, não se obtém a desejável mas inalcançável precisão absoluta. Isso somente é possível quando da elaboração do projeto concluído (as built).

Nesse sentido, estava correta a Norma NBR-5670/77 da ABNT, datada de 1977, quando definia projeto básico como "Projeto que reúne os elementos, discriminações técnicas necessárias e suficientes à contratação da execução do mesmo", enquanto projeto executivo era o "Projeto que reúne os elementos necessários e suficientes à execução completa do mesmo", e projeto concluído ("as built") era a "Definição qualitativa e quantitativa de todos os serviços executados, resultante do projeto executivo com as alterações e modificações havidas durante a execução".

23 Estratégia que consiste em balancear os preços unitários de serviços, aumentando-os ou diminuindo-os em função de possíveis variações das respectivas quantidades a serem executadas, priorizando algumas atividades iniciais. (Nota nossa). 
A inevitável imprecisão do projeto básico nas contratações administrativas é admitida na alínea " $b$ " do inciso I do art. 65 da Lei 8.666/93, quando prevê a necessidade de acréscimo ou diminuição quantitativa do objeto do contrato.

Todo e qualquer acréscimo do valor contratual deve ser solidamente justificado, mesmo que mínimo. Na prática, costuma-se entender que o limite de $25 \%$, estabelecido nos $\$ \int$ $1^{\circ}$ e $2^{\circ}$ do art. 65 da Lei 8.666/93 para os contratos administrativos, é uma espécie de "crédito automático". Vale dizer: é como se a Administração estivesse autorizada a proceder a extensões contratuais até aquele limite, independentemente de motivação. Esta talvez seja uma das razões que levam a Administração a deparar-se, ao final da execução da obra ou empreendimento, com a incômoda situação de ter que ultrapassar o limite legal para evitar o mal maior de ter que rescindir o contrato.

Note-se que há uma aparente contradição entre o art. $3^{\circ}$, alínea " $f$ ", da Resolução no 361/91 da CONFEA, que diz ser uma das características principais do projeto básico "definir as quantidades e os custos de serviços e fornecimentos com precisão compativel com o tipo e porte da obra, de tal forma a ensejar a determinação do custo global da obra com precisão de mais ou menos $15 \%$ (quinze por cento)", e as normas dos $\iint 1^{\circ}$ e $2^{\circ}$ do art. 65 da Lei 8.666/93. A norma do CONFEA - que reforça o entendimento acima de que não existe precisão absoluta na estimativa de quantidades pelo projeto básico - tem como destinatários os projetistas, e vale para todos os contratos, de direito privado ou administrativos. O CONFEA admite uma margem de imprecisão de 15\%. Um bom projeto básico é o que se contém nessa margem de imprecisão. Em relação aos contratos administrativos, a lei admite extensões contratuais, inclusive decorrentes de alterações de projeto, até $25 \%$, calculados sobre o valor global estimado, e não sobre o valor estimado de cada item da planilha. Trata-se de norma que tem por destinatários os agentes administrativos.

Volto ao "jogo de planilha". O TCU tem entendido que na hipótese de aumentos ou reduções significativas de quantidades a Administração deve renegociar os respectivos preços, com vista a reduzi-los ou aumentá-los, conforme o caso. Isso em função da economia de escala.

Vale mencionar duas decisões do TCU sobre o assunto.

No Acórdão no 1.684/2003 - Plenário, o Relator, Ministro Marcos Vinicios Vilaça, mencionou o fato de que a empresa vencedora da licitação elaborou proposta em que subavaliou os preços unitários dos serviços com utilização de motoscraper e superavaliou os preços unitários dos serviços de caminhão. Posteriormente, os contratantes substituíram o motoscraper por caminhão. Em casos como este, disse o Ministro-Relator, é indispensável que os preços sejam renegociados, "para que se mantenha o equilíbrio original" (itens 11 a 24 do Voto do Relator).

Já na Decisão no 1.028/2001 - Plenário, o Ministro Relator, Ubiratan Aguiar, sustentou, em seu Voto, que deveria haver uma "compensação" entre os itens que apresentavam valores superavaliados e aqueles que consignavam preços subavaliados. Afirmou ele: "Pretender-se, portanto, reduzir os precos inicialmente contratados daqueles itens que se encontravam superavaliados, sem alterar-se aqueles que se encontravam subavaliados, implicaria em eliminar-se a 'compensação' inicialmente existente, com a conseqüente alteração do equilíbrio econômicofinanceiro dos contratos".

Vale acentuar que dois princípios vêm ganhando cada vez maior espaço no direito administrativo: o da razoabilidade e o da economicidade. O primeiro corresponde à lógica do razoável, exposta sobretudo pelo jurista belga Chaïm Perelman. São vários os ensaios de Perelman sobre esse tema, reunidos em livro publicado em Bruxelas em 1990 e traduzido para o português e publicado no Brasil pela Martins Fontes ("Ética e Direito”, São Paulo, 1996). O segundo, inscrito no art. 70 da Constituição Federal, traduz, no campo do direito, a relação custo-benefício.

Sobre a acolhida do princípio da economicidade pelo TCU, veja-se "O Princípio Constitucional da Economicidade na Jurisprudência do Tribunal de Contas da União", de autoria do Subprocurador-Geral do Ministério Público junto àquela Corte de Contas, Paulo Soares Bugarin (Belo Horizonte, Editora Fórum, 2004). Escreve Bugarin que tanto a doutrina quanto a jurisprudência do TCU reconhecem " a 'umbilical' relação entre os princípios da economicidade e razoabilidade (proporcionalidade)" (p. 216) e que a economicidade se põe em dois planos materiais: no primeiro, "acolheria a idéia do 
máximo resultado possível" e, no segundo, "se fixa mais no aspecto menor custo possível, dado um resultado já definido que se visa a alcançar” (p. 212). (AMARAL, 2006b).

As reivindicações contratuais mais comuns decorrem das seguintes alterações: (i) nas condições de execução do objeto do contrato; (ii) na supressão ou acréscimo de serviços contratados; (iii) nas especificações técnicas; (iv) nos prazos; $(v)$ no processo construtivo; e ( $v i)$ nos preços ou condições de pagamento. Em geral, o contrato estabelece referências e critérios para a solução de disputas oriundas de mudanças nas condições de execução do objeto, fornecimentos, preço, prazos, interferências, qualidade e outros, enquanto a legislação estabelece direitos e obrigações referentes a caso fortuito e força maior.

A Fédération Internationale des Ingénieurs-Conseils - FIDIC, presente em mais de 60 países, representa uma grande parte das práticas de consultoria privada em engenharia no mundo. Seus trabalhos sobre condições contratuais para projetos têm sido largamente utilizados e reconhecidos, entre outros méritos, por seus princípios de divisão equilibrada de riscos entre a contratante e a contratada (FIDIC, 1999). A entidade assim define Força Maior e se posiciona a respeito das suas conseqüências:

\footnotetext{
"Força Maior" significa um evento ou uma circunstância excepcional: (a) que esteja além do controle da Parte; (b) que a parte não poderá ter razoavelmente previsto antes de participar do contrato; (c) que, ao ter ocorrido, tal Parte não pôde razoavelmente evitar ou superar, e (d) que não é substancialmente atribuível à outra Parte.

[...] Se a contratada não puder efetuar quaisquer de suas obrigações devido à Força Maior, e ainda sofrer atraso e/ou incorrer em custos, terá direito à reivindicação no que se refere a: uma prorrogação do prazo correspondente a tal atraso, caso a conclusão esteja ou venha a ficar atrasada, [...] e [...] ao pagamento de tais custos. (FIDIC, 1999, p. 50-51, tradução do autor).
}

As partes devem tentar resolver, por negociação direta entre elas, qualquer diferença surgida da interpretação do contrato e dos documentos que o integram, ou da ocorrência de fato imprevisível, ou previsível mas de conseqüências incalculáveis. Quando a negociação falhar, podem recorrer a processos alternativos de solução de disputas, evitando ingressar em juízo.

A negociação entre as partes constitui o processo menos formal, além de mais rápido e mais barato; no outro extremo, o julgamento por tribunal é o mais formal, demorado e caro. No Brasil, é relativamente recente a utilização de processos alternativos de solução de disputas, entre eles a mediação e a arbitragem. Qualquer que seja o processo, a negociação é o único em que as partes atuam sem o auxílio de uma terceira parte neutra. 
A mediação é "um processo voluntário de resolução de disputas, envolvendo uma parte neutra, ou mediadora, que não decide, mas é uma facilitadora” (Coppi et al., 2001, p. 496, tradução nossa). Nazareth diz que o objetivo da mediação "é restabelecer a comunicação produtiva e colaborativa entre as pessoas que se encontram em um impasse, ajudando-as a chegar a um acordo" (2006, p. 130).

Os membros da parte mediadora (“junta de mediação") são independentes, devendo analisar qualquer disputa por meio de interpretação do contrato, promover audiências entre as partes e emitir uma recomendação de como interpretar o contrato. No relatório final da junta deverão constar: (i) a definição das partes envolvidas no litígio; (ii) a descrição do entendimento do problema pela junta; e (iii) a recomendação de solução proposta pela junta. Se qualquer das partes não concordar com a recomendação da junta, poderá comunicar à outra parte a sua decisão de recorrer à arbitragem (DRBF, 2004).

A decisão arbitral é final e impositiva para ambas as partes. O contrato deverá prever, em cláusula própria de resolução de controvérsias, os passos e os prazos de condução da mediação e da arbitragem, indicando para este último processo, a Câmara escolhida, a eleição dos árbitros e a legislação aplicável, entre outras disposições. No Brasil, a arbitragem foi consolidada em setembro de 1996, pela Lei n. 9.307, mas somente se tornou aplicável aos contratos administrativos em dezembro de 2004, com a promulgação da Lei n. 11.079 (“Lei das PPP”). Os Quadros 3.2 e 3.3 mostram prós e contras dos processos de mediação e de arbitragem.

\begin{tabular}{|c|c|}
\hline Vantagens da mediação & Desvantagens da mediação \\
\hline - Privacidade & - As partes neutras não têm o poder de impor acordo \\
\hline - As partes controlam o foro & - Não tem o poder de obrigar a participação das partes \\
\hline - As partes envolvidas escolhem as partes neutras & -Proporciona pouco acesso à informação \\
\hline - Reflete as preocupações e as prioridades das disputas & - Não tem as devidas salvaguardas processuais \\
\hline •É flexível & - Uma parte poderosa pode influenciar o resultado \\
\hline - O processo instrui os litigantes & - O encerramento é fraco \\
\hline - Trata dos problemas básicos & • Não gera obrigações \\
\hline & $\begin{array}{l}\text { - Falta-Ihe o caráter da aplicabilidade ou do cumprimento } \\
\text { obrigatórios }\end{array}$ \\
\hline \multirow{3}{*}{$\begin{array}{l}\text { - Registra uma alta taxa de cumprimento das decisões } \\
\text {-É relativamente barata }\end{array}$} & •Não anlica ou decenvolve normas núblicas \\
\hline & \\
\hline & - O resultado não necessita ser baseado em princípios \\
\hline
\end{tabular}

FONTE: Cooley e Lubet (2001, p. 31-32).

Quadro 3.2 - Prós e contras do processo de mediação. 


\begin{tabular}{|c|c|}
\hline Vantagens da arbitragem & Desvantagens da arbitragem \\
\hline - Privacidade & - Falta-Ihe controle de qualidade \\
\hline - As partes controlam o foro & -As partes neutras não são responsabilizáveis \\
\hline •Especialização & $\begin{array}{l}\text { •Vem-se tornando crescentemente assoberbada por } \\
\text { "legislação" }\end{array}$ \\
\hline - As partes envolvidas escolhem as partes neutras & \\
\hline - Há procedimentos escritos & - As regras quanto à prova são lenientes \\
\hline •É rápida & -A revelação dos fatos é limitada ou inexistente \\
\hline - Há escolha das normas aplicáveis & • Não há normas públicas \\
\hline - Há a possibilidade de soluções sob medida para as situações & • Não há precedentes \\
\hline •É suscetível de vigência ou aplicação obrigatórias & • Não há uniformidade \\
\hline •É relativamente barata & - Normalmente não há razões escritas para a decisão \\
\hline & - Normalmente não cabe recurso \\
\hline
\end{tabular}

FONTE: Cooley e Lubet (2001, p. 31-32).

Quadro 3.3 - Prós e contras do processo de arbitragem.

\subsection{REIVINDICAÇÕES}

O PMI conceitua como reivindicação, "uma solicitação, exigência ou declaração de direitos feita por um fornecedor em relação a um comprador ou vice-versa, para consideração, compensação ou pagamento sob os termos de um contrato legal, como no caso de uma mudança contestada" (2004, p. 374). O termo reivindicar tem o significado de reclamar aquilo a que se acredita ter direito, solicitando uma compensação. $\mathrm{O}$ ato de reivindicar exige o encaminhamento formal à outra parte, pela que se sente prejudicada, de pedido de ressarcimento por ônus incorridos, apresentado tempestivamente e de maneira fundamentada.

\footnotetext{
A reivindicação visa restabelecer o equilíbrio econômico-financeiro pactuado entre as partes na assinatura do contrato que se vê rompido ao longo do desenvolvimento da obra. Esse desequilíbrio pode ter uma proporção considerável no total do contrato, especialmente em projetos grandes e complexos. (PEDROSA e ROCHA LIMA JR., 1994, p. 2).
}

As reivindicações surgem em conseqüência de alterações contratuais, que podem decorrer "(a) de um novo acordo entre as partes, em que se renegociam determinadas cláusulas (alterações bilaterais); (b) da vontade exclusiva da contratante (alterações unilaterais)" (AMARAL, 2006a, p. 223, grifo do autor). O autor prossegue, acentuando:

Em relação às alterações bilaterais, o gestor do contrato não enfrenta grandes problemas. [...] Já as alterações unilaterais podem ser expressas ou tácitas. Quando 
ocorrem alterações unilaterais tácitas, o gestor do contrato deve estar bem atento para percebê-las de imediato. Em qualquer hipótese, deve ele analisar as repercussões da alteração no contrato e tomar as providências imediatas ou para promover a renegociação de cláusulas em que se verifique repercussão, ou para ressalvar direitos perante a outra parte. (AMARAL, 2006a, p. 223-224, grifo do autor).

Considerando os pressupostos para o reequilíbrio do contrato, apresentados no item 3.3 do Capítulo 3 desta dissertação, conclui-se que não tem sentido a reivindicação formulada pela contratada, com o propósito de reparar erros cometidos na proposta, ou que pretenda o ressarcimento de ônus incorridos ao longo da execução do contrato, em qualquer das seguintes situações:

- Impossibilidade de executar conforme especificado pela contratante e aceito em contrato;

- Deficiência em providenciar, em tempo adequado, ensaios, especificações e desenhos de sua responsabilidade;

- Deficiência em fornecer, em tempo adequado, bens sob encomenda e materiais de sua responsabilidade;

- Modificações ou cancelamentos de desenhos e/ou especificações técnicas, por sua própria iniciativa e sem autorização prévia e expressa da contratante;

- Baixa produtividade;

- Deficiência de coordenação e integração das atividades.

As partes devem preparar-se para identificar e avaliar qualquer alteração que ocorra nas condições estabelecidas em contrato, para decidir sobre a providência que tomarão a respeito. A parte afetada poderá decidir absorver o impacto da alteração, ou reclamar à outra parte, solicitando: (i) re-adequação de preço, ou ressarcimento de ônus incorridos, e/ou (ii) a fixação de novo cronograma físico-financeiro contratual. $\mathrm{O}$ acolhimento da reclamação da contratada exige que o contrato seja aditado, como foi visto anteriormente na parte 1.3 deste Capítulo 3.

Os critérios de quantificação e conseqüente valorização dos custos adicionais são técnicos, partindo sempre da premissa que a proposta foi elaborada em condições otimizadas, de máxima produtividade (McMANUS et al., 1996; SCHWARTZKOPF, 1995; SCHWARTZKOPF e MCNAMARA, 2001). 
Do ponto de vista da Contratada, as principais causas de reivindicação podem ser classificadas ${ }^{24}$ em quatro grandes grupos:

1) Atrasos da Contratante, ou por ela motivados, em situações tais como: emissão da Ordem de Início de Serviço, entrega de desenhos de projetos e/ou de especificações técnicas, liberação de acessos e áreas para trabalho ou instalação de canteiros, remoção de interferências de sua obrigação, aprovação de documentos, pagamento de faturas;

2) Modificação, pela Contratante, de cláusulas ou documentos integrantes do contrato, tais como: extensão ou supressão de serviços do objeto, compressão ou dilatação de prazos, alteração de elementos do projeto básico ou executivo, alteração do método construtivo e/ou da seqüência executiva;

3) Variação de quantidades de serviços previstos no contrato; e

4) Condições climáticas e/ou geológicas de conseqüências incalculáveis.

"Uma reivindicação de reequilíbrio econômico-financeiro deve ser acompanhada de sólida fundamentação jurídica, e estar bem demonstrada e quantificada", alerta Amaral (2006b), ressaltando que:

\footnotetext{
Na prática, é comum encontrarmos pleitos de reequilíbrio referentes a contratos que já nasceram desequilibrados, quer em decorrência de erro na formação do preço proposto, quer - o que é pior - de "mergulho". Nesses casos, a reivindicação é insustentável, já que o pleito objetiva não o reequilíbrio do contrato, mas o equilíbrio que lhe faltou na formação do vínculo contratual. (AMARAL, 2006b).
}

O ciclo completo de uma reivindicação contratual feita pela parte contratada envolve as seguintes etapas básicas ${ }^{25}$ : (a) análise da conveniência, (b) apresentação à contratante, (c) negociação, e (d) liquidação.

\section{a) Análise da conveniência.}

$\mathrm{Na}$ primeira etapa, a contratada avalia a probabilidade de sucesso da reivindicação. A tomada de decisão de apresentá-la ou não à contratante depende das respostas às seguintes questões:

- O que exatamente se quer reclamar?

24 Classificação sugerida por Antônio Carlos Cintra do Amaral ao autor (informação verbal).

25 Adaptado de Ricardino (2006) e de outros seminários conduzidos por este autor, desde 1996, para empresas públicas e privadas. 
- Qual o processo de solução de disputas previsto no contrato?

- Quais as circunstâncias e como deve ser estruturada a reclamação?

- É possível demonstrar que efetivamente se trata de modificação do contrato?

- É possível à contratada provar que é inimputável?

- É possível quantificar o prejuízo?

- Há registros? E há documentação de suporte?

- Quais os pontos fracos da contratada, no que tange ao cumprimento das suas próprias obrigações?

\section{b) Apresentação.}

Etapa de elaboração e apresentação formal do pleito à contratante, abrangendo mas não se limitando às seguintes ações:

- Mobilização de equipe responsável por elaborar a reivindicação;

- Definição da estratégia de elaboração, apresentação e acompanhamento;

- Definição da modelagem do produto final a ser apresentado;

- Programação das atividades até apresentação do pleito;

- Prestação de esclarecimentos prévios à contratante; e

- Apresentação formal à contratante.

\section{c) Negociação.}

Esta terceira etapa requer o cumprimento das atividades indicadas a seguir:

- Ativação e acompanhamento;

- Reuniões de prestação de esclarecimentos adicionais à contratante;

- Atendimento a solicitações adicionais da contratante;

- Negociação e acordo.

d) Liquidação.

Nesta quarta e última etapa, a contratante reconhece formalmente a dívida e/ou o novo prazo contratual. Caso isso não ocorra, a reclamante poderá notificar a contratante, de que está dando início ao processo de mediação. No caso em que este venha a falhar, fica acionada a 
arbitragem, tudo dependendo das disposições contratuais a respeito. Conforme o esquema constante da Figura 3.2, o reconhecimento mencionado anteriormente compreende as seguintes atividades:

- Aprovação formal, pela contratante, da negociação realizada;

- Celebração de Termo Aditivo ao contrato; e

- Autorização e pagamento à reclamante. A ressaltar que somente poderá existir pagamento se houver Termo Aditivo que o ampare.

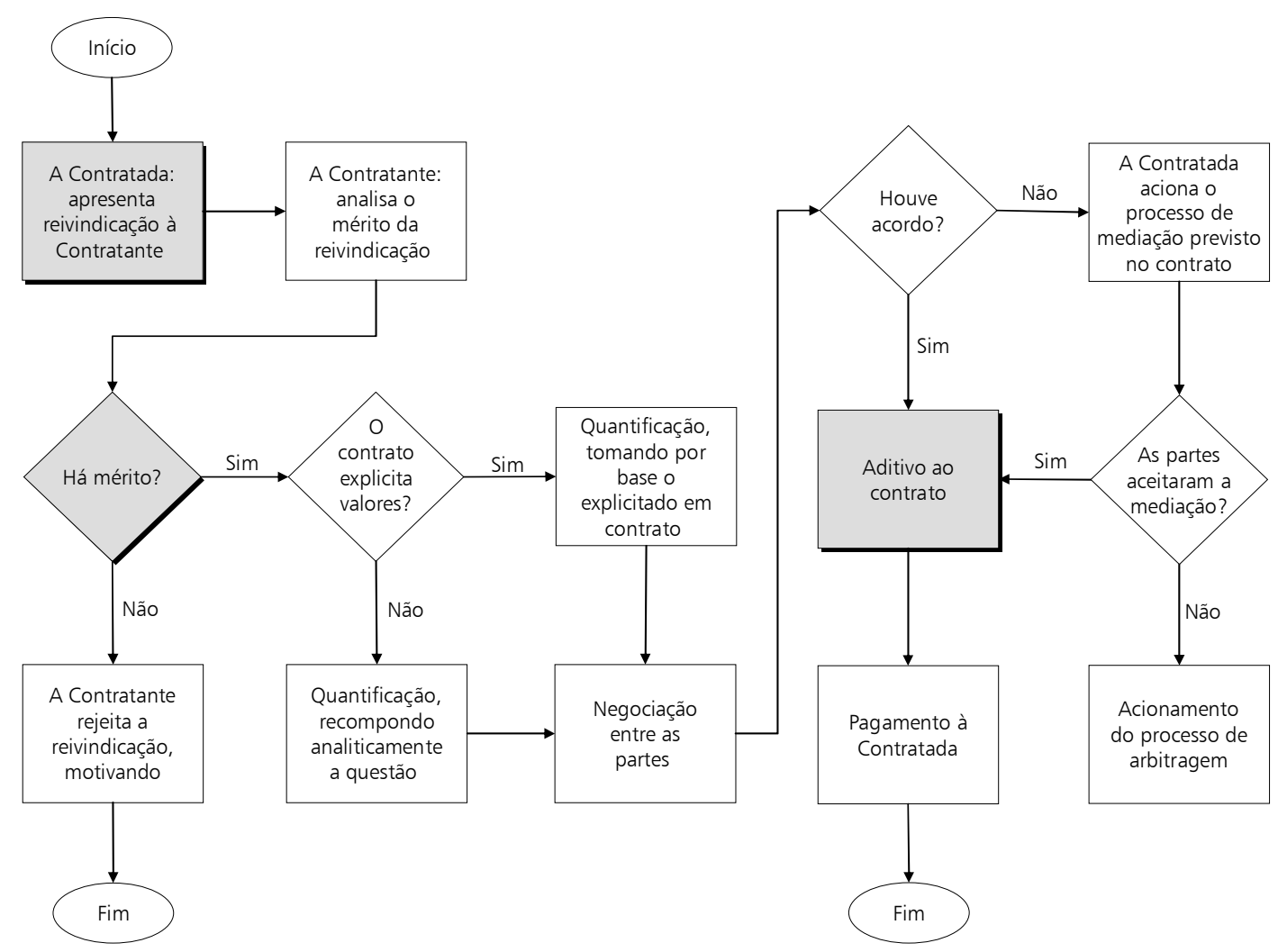

FONTE: Elaborado pelo autor, com posterior adaptação com base em McManus et al. (1996).

Figura 3.2 - Mapa do processo de alteração do contrato.

\subsection{TÉCNICAS E HABILIDADES INFLUENTES NA GESTÃO DE PROJETOS E DE CONTRATOS}

A moderna gestão de empreendimentos requer do gerente um conjunto de habilidades que facilite e calibre a tomada de decisões técnicas e empresariais, destacando-se, dentre elas, "O conhecimento empresarial, o gerenciamento de riscos e as habilidades de integração", segundo 
Kerzner (2006a, p. 232). Por sua vez, Wysocki e Lewis (2000) afirmam ter constatado que os requisitos à boa prática do Gerenciamento de Projetos podem ser descritos por meio de um conjunto de técnicas e habilidades, que se vinculam ao tema deste trabalho, agrupando-os em 5 grandes categorias, como mostra o Quadro 5.1.

\begin{tabular}{|c|c|}
\hline Gerenciamento de projetos & Habilidades de negócio \\
\hline Desenvolvimento do Termo de Abertura & Orçamento \\
\hline Avaliação da complexidade & Avaliação estratégica do negócio \\
\hline Estimativa do custo & Funções do negócio \\
\hline Gestão do custo & Concepção de engenharia \\
\hline Caminho crítico da gestão & Produtos/serviços da empresa \\
\hline Detalhamento da estimativa & Serviços ao cliente \\
\hline Planejamento do projeto & Implementação \\
\hline Finalização do projeto & Planejamento estratégico e tático \\
\hline Software para gestão do projeto & Estimativa do produto do vendedor \\
\hline Memória técnica da execução & Políticas e procedimentos \\
\hline Manutenção & Integração de sistemas \\
\hline Organização do projeto & Testes \\
\hline \multicolumn{2}{|l|}{ Avaliação progressiva do projeto } \\
\hline Aquisição de recursos materiais & Habilidades no relacionamento \\
\hline Designação de recursos humanos & Gestão de conflitos \\
\hline Requisitos dos recursos & Flexibilidade \\
\hline Programação do desenvolvimento & Influenciador \\
\hline \multirow[t]{2}{*}{ Gerenciamento do escopo } & Sociabilidade \\
\hline & Negociando \\
\hline Habilidades de gerenciamento & Gestão do relacionamento \\
\hline Delegação & Formador de equipe de gerenciamento \\
\hline \multicolumn{2}{|l|}{ Liderança } \\
\hline Gestão de mudanças & Habilidades pessoais \\
\hline Gestão simultânea de múltiplas prioridades & Criatividade \\
\hline Gestão de reuniões & Tomador de decisões/ Pensamento crítico \\
\hline Gestão do desempenho & Apresentador \\
\hline Gestão da qualidade & Solucionador de problemas \\
\hline Desenvolvimento das pessoas & Comunicações verbais \\
\hline Seleção e contratação de pessoas & Comunicações escritas \\
\hline
\end{tabular}

FONTE: $\quad$ Wysocki e Lewis (2000, p. 82, tradução do autor).

OBSERVAÇÃO: Em cada um dos conjuntos de técnicas e habilidades, a apresentação das variáveis respeita a ordem alfabética do texto original em inglês.

Quadro 3.4 - Técnicas e habilidades influentes na gestão de projetos e de contratos. 
Há uma relação direta entre algumas habilidades dos integrantes da equipe de gerenciamento e o êxito de um projeto, diz Domingues [ca. 2004]. O mencionado autor acentua a importância do gerente, o responsável por fazer com que os demais interessados diretos no projeto desempenhem seus papéis da melhor maneira possível, dentro do prazo, custo e qualidade estabelecidos em contrato. Essa posição é reforçada por Dinsmore e Silveira Neto (2005), que afirmam:

Não há uma descrição padrão e adequada que contemple as sutis variações necessárias ao gerente de projeto. O que existe é um conjunto de recomendações clássicas para todas as posições de gerenciamento de projetos:

-o gerente de projetos é sempre responsável por levar o projeto ao término para satisfação das partes interessadas e dentro dos parâmetros de tempo (programação), custo (orçamento) e qualidade (desempenho);

-sua autoridade para desempenhar suas funções pode variar desde quase nada até total;

-seu trabalho permanece praticamente o mesmo em todos os projetos, mas as técnicas para atingir as metas devem ser usadas sob medida para se ajustarem a cada projeto específico.

Isso pede que gerentes de projetos desenvolvam três papéis fundamentais. O primeiro é o papel interpessoal, o qual inclui as funções: líder figurativo, liderança e figuração. Segundo, o gerente desempenha um papel informacional, que envolve disseminar a informação e agir como um porta-voz. O terceiro papel é aquele de tomar decisões, no qual o gerente age como empresário, alocador de recursos e negociador. Esses papéis são amplos em escopo e geralmente se aplicam a qualquer situação de gerenciamento. (DINSMORE e SILVEIRA NETO, 2005, p. 22).

Thamhain e Wilemon apud Dinsmore e Silveira Neto (2005) expressam idéia semelhante à de Wysocki e Lewis (2000), agrupando as técnicas e habilidades requeridas à boa prática do gerenciamento de projetos em seis categorias, conforme transcrito a seguir:

\section{Liderança}

- Direção e liderança claras.

- Participação na solução de problemas e tomada de decisões técnicas.

- Delineamento claro de metas e objetivos.

- Unir a equipe em torno das metas do projeto.

- Delegar sempre.

- Tomada de decisões firme.

Experiência técnica

- Compreender as tecnologias envolvidas no projeto.

- Compreender as aplicações, mercados e requisitos do cliente.

- Gerenciar tecnologia.

- Avaliar riscos e negócios.

- Antever tendências tecnológicas.

- Dar assistência na solução de problemas.

- Comunicar-se eficazmente com a equipe técnica.

\section{Habilidades comportamentais}

- Formar equipes multidisciplinares.

- Envolver e estimular o pessoal.

- Gerenciar conflitos. 
- Comunicar-se oralmente e por escrito em todos os níveis.

- Fomentar um ambiente de trabalho que conduza ao trabalho em equipe.

- Envolver a direção e gerentes seniores.

Técnicas de gestão

- Planejamento do projeto.

- Negociação de recursos.

- Comprometimento com a segurança.

- Estabelecer marcos mensuráveis.

- Estabelecer procedimentos operacionais.

- Estabelecer e manter relatórios e revisões.

- Estabelecer e gerenciar controles do projeto.

- Uso eficaz de ferramentas e técnicas de programação.

- Planejamento eficaz da mão-de-obra.

Técnicas organizacionais

- Formar equipes de trabalho multifuncionais.

- Trabalhar eficazmente com a direção e gerentes seniores.

- Compreender interfaces organizacionais.

- Estabelecimento de uma organização eficaz.

- Compreender como funciona a organização e como trabalhar eficazmente com ela.

Técnicas empresariais

- Capacidade gerencial.

- Gerenciar projetos como negócios.

- Atingir objetivos lucrativos.

- Desenvolver negócios novos e acompanhá-los.

$\mathrm{Na}$ análise detalhada dessas características e habilidades, é significativo notar que a interação comportamental é um tema primordial que acontece em todas as categorias técnicas - mesmo a categoria denominada experiência técnica. (DINSMORE e SILVEIRA NETO, 2005, p. 25-27).

As técnicas e habilidades influentes na gestão de Projetos e de contratos, apontadas neste item 3.5, e os estudos de McManus; Jentzen; Greenberg (1996) sobre reivindicações contratuais, constituíram o conjunto referencial considerado na elaboração do questionário constante do APÊNDICE A da dissertação.

Vale notar que os autores dos trabalhos citados anteriormente não dão destaque particular a nenhuma das técnicas e habilidades apontadas por eles, mas sim realçam a importância do conjunto delas para o sucesso do Projeto. 


\section{INTERFACE ENTRE OS PROCESSOS DE ADMINISTRAÇÃO DE CONTRATO E ANÁLISE DO RISCO}

A palavra "risco" deriva do italiano antigo risicare, que significa "ousar". Neste sentido, o risco é uma opção, e não um destino.

(Peter Bernstein)

\subsection{O RISCO NO CONTEXTO DO PROCESSO DE CONTRATAÇÃO}

Risco, no significado corrente em dicionários, tem as seguintes acepções: “(1) perigo ou possibilidade de perigo; (2) situação em que há probabilidades mais ou menos previsíveis de perda ou ganho; (3) em contratos de seguros, evento que acarreta o pagamento de indenização; (4) Jur. Possibilidade de perda ou de responsabilidade pelo dano" ${ }^{\text {26 }}$. Dessas quatro acepções, a segunda é a única a admitir que o risco também pode ser visto por um aspecto favorável; todas as demais o consideram somente uma ameaça.

A Associação Brasileira de Normas Técnicas define risco ${ }^{27}$ como "a combinação da probabilidade de um evento e de suas conseqüências" (grifos do autor), admitindo que "geralmente, o termo 'risco' é utilizado apenas quando há pelo menos a possibilidade de conseqüências negativas". Em seguida, define conseqüência como "o resultado de um evento", observando que "pode haver mais de uma conseqüência de um evento", e que "as conseqüências podem ser positivas ou negativas. Entretanto, as conseqüências são sempre negativas no que se refere aos aspectos de segurança”. E reconhece:

Cada vez mais, as organizações utilizam os processos de gestão de riscos para otimizar a gestão das potenciais oportunidades. Isto difere do processo de análise/avaliação de riscos explicado no ISO/IEC Guide 51, onde o risco é tido como algo que produz apenas conseqüências negativas. (ABNT ISO/IEC 73, 2005).

${ }^{26}$ FERREIRA, Aurélio Buarque de Holanda. Novo Aurélio Século XXI: o dicionário da língua portuguesa. 3. ed. Rio de Janeiro: Nova Fronteira, 1999.

27 ABNT ISO/IEC Guia 73 (2005), p. 2. O objetivo desta norma, segundo a ABNT, é fornecer "definições genéricas de termos de gestão de riscos para a elaboração de normas. Seu propósito é ser um documento genérico de alto nível, voltado para a preparação ou revisão de normas que incluam aspectos de gestão de riscos”. 
A Figura 4.1 ilustra, no processo de contratação, os três principais momentos de escolha e aceitação de riscos pelo gerente de projeto da parte vendedora, bem como os desafios a serem superados em cada um desses momentos.

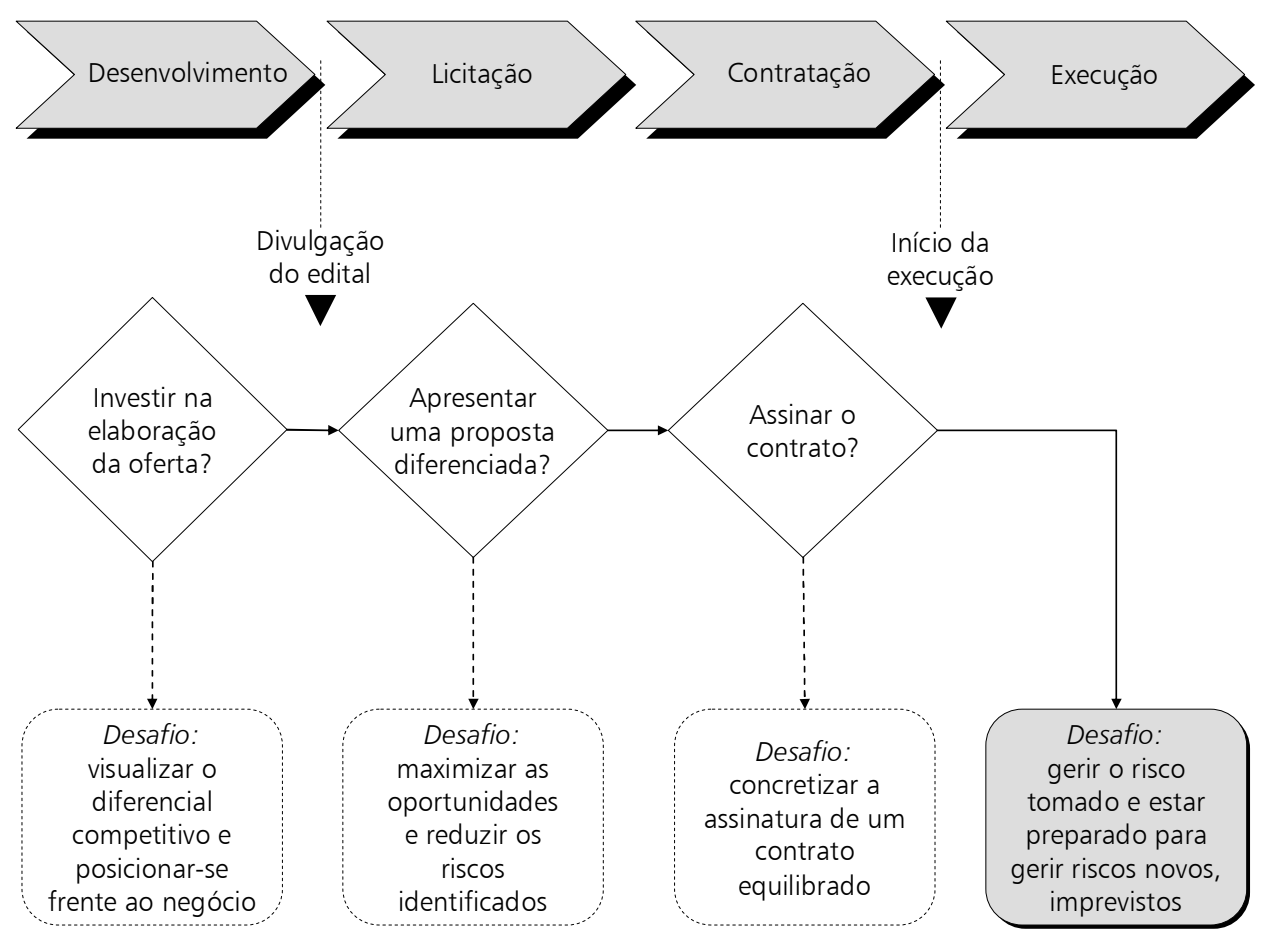

FONTE: Adaptado pelo autor a partir de Andriolo; Maionchi; Ricardino (2000).

Figura 4.1 - Momentos de escolha e aceitação do risco.

Para os fins deste trabalho, o termo "risco" tem o significado de evento ou condição latente que, em se efetivando, pode causar impacto negativo em um objetivo do Projeto - sem embargo do reconhecimento da validade do outro significado do referido termo. Constituem exemplos de riscos de conseqüências negativas:

- A possibilidade de não se atingir uma determinada meta, por atraso na execução de um serviço;

- A possibilidade de redução ou perda do resultado esperado, pela ocorrência de despesas acima do orçado;

- A possibilidade do desempenho da mão de obra não corresponder aos índices de produtividade imaginados.

Wideman (1992); Chapman e Ward (1997); Schuyler (2001) dizem que todo risco tem três componentes: (i) uma causa ou evento, (ii) a probabilidade de ocorrência desse evento, e (iii) o efeito ou impacto da ocorrência desse evento. A natureza subjetiva dos componentes dos riscos 
que afetam particularmente os empreendimentos de construção pesada, associada às atividades requeridas à sua gestão, adiante descritas neste Capítulo, exigem que o Gerente da parte vendedora faça uma criteriosa análise do risco de execução do projeto antes de aceitá-lo, ou seja, antes de assinar o respectivo contrato.

\subsection{PRINCÍPIOS DO GERENCIAMENTO DE RISCOS}

O gerenciamento de riscos é, segundo Kertzner, "uma forma organizada de identificar e medir os riscos e de desenvolver, selecionar e gerenciar as opções para seu controle" (2006a, p. 328). Deve-se entender o termo controle com o significado que lhe é atribuído pela ABNT (ISO/IEC Guia 73, 2005), qual seja, o de conjunto de ações que implementam as decisões da gestão de riscos, podendo envolver monitoramento, reavaliação e conformidade com as decisões. O Guia PMBOK (PMI, 2004) também emprega o termo com esse sentido. Controla-se o processo, não o risco. Em se tratando de gerenciamento de riscos, é inaceitável o emprego do termo "controle" com o significado constante em dicionário, que é o de "ato, efeito ou poder de controlar; domínio; governo".

Wideman (1992) afirma que a finalidade do gerenciamento de riscos é direcionar a incerteza para a oportunidade representada por uma situação nova, afastando o risco nela contido. Trata-se, portanto, de uma função pró-ativa, e não meramente reativa.

Segundo o PMI (2004), os processos mais diretos que o gerente aplica para gerir os riscos de um empreendimento são os seguintes: (a) planejamento do gerenciamento de riscos, (b) identificação de riscos, (c) análise qualitativa e (d) análise quantitativa dos riscos identificados, (e) planejamento de respostas a riscos, e (f) monitoramento e controle dos processos de gestão de riscos.

Os cinco primeiros processos são utilizados durante a formulação da proposta e negociação do contrato, proporcionando o surgimento do plano de Administração de Contrato. O sexto e último processo desenvolve-se após a assinatura do contrato, assinalando o seu progresso. 


\section{a) Planejamento do gerenciamento de riscos.}

Neste primeiro processo, são fixados os critérios e previstos os métodos e ferramentas de gestão de riscos ao longo do ciclo de vida do empreendimento, e são estabelecidas as políticas e expectativas de custo para sua aquisição e implantação.

\section{b) Identificação de riscos.}

Processo em que são relacionados e classificados os fatores que poderão afetar o empreendimento, com a utilização de vários instrumentos, dentre os quais se destacam:

- Diagramas de causa e efeito;

- Listas de verificação (“checklists");

- Reuniões de "brainstorming",

- Consultas a documentos e entrevistas com pessoas, sobre situações e projetos já executados.

\section{c) Análise qualitativa de riscos.}

Processo que consiste na avaliação do impacto dos fatores de risco identificados e da probabilidade da sua ocorrência. $\mathrm{Na}$ análise qualitativa, o gerente prioriza os riscos de acordo com seu efeito potencial nos objetivos do projeto, classificando-os em categorias ("alto", “médio" ou "baixo”), ou mesmo utilizando técnicas mais apuradas para graduá-los.

\section{d) Análise quantitativa de riscos.}

À análise qualitativa segue-se a análise quantitativa, voltada ao tratamento estatístico dos fatores de risco, visando determinar o grau de confiança da ocorrência singular de cada um deles. As principais ferramentas utilizadas para quantificar riscos são: (i) análise de sensibilidade, (ii) árvore de decisão, e (iii) métodos de simulação.

28 "Uma técnica geral de coleta de dados e criatividade que pode ser usada para identificar riscos, idéias ou soluções para problemas usando um grupo de membros da equipe ou especialistas no assunto. Normalmente, uma sessão de brainstorming é estruturada de forma que as idéias de cada participante são registradas para análise posterior". (PMI, 2004, p. 354). 
As análises qualitativa e quantitativa indicam o nível de exposição do empreendimento ao risco, podendo o seu resultado conduzir à desistência de se apresentar proposta, ou de se assinar o contrato.

e) Planejamento de respostas aos riscos.

Processo que consiste no "desenvolvimento de opções e ações para aumentar as oportunidades e reduzir as ameaças aos objetivos do projeto" (DINSMORE e CAVALIERI, 2005, p. 191). Este processo inclui as técnicas de exclusão, transferência, mitigação e aceitação de riscos, que são discutidas no item 4.3 deste Capítulo 4.

\section{f) Monitoramento e controle da gestão de riscos.}

O sexto e último processo ocorre na etapa de execução do contrato, assinalando o desenvolvimento da Administração de Contrato, cujos princípios básicos, atividades e funções foram estudados no Capítulo 3 deste trabalho. A Figura 4.2 representa o conjunto dos seis processos descritos anteriormente.

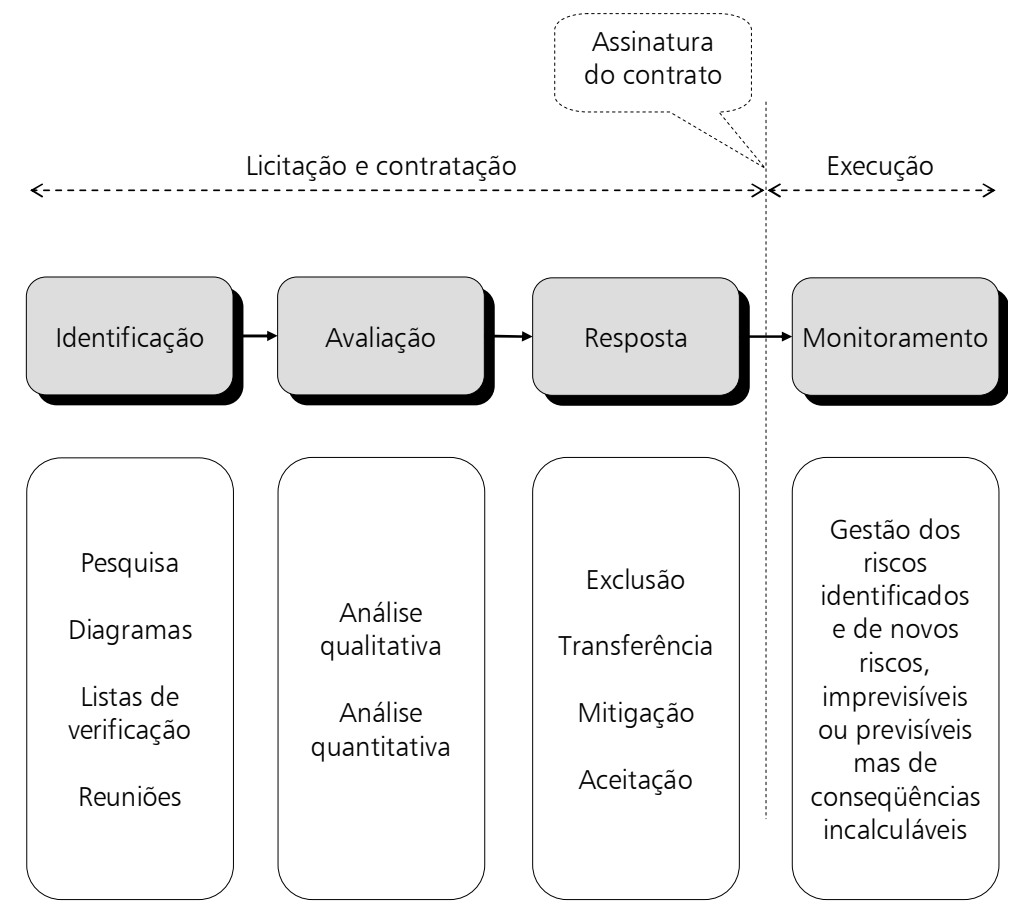

FONTE: Adaptado pelo autor a partir de Wideman (1992).

Figura 4.2 - Matriz do processo de gerenciamento de riscos. 


\subsection{PLANEJANDO AS RESPOSTAS A RISCOS}

Tendo identificado e avaliado os riscos à execução do empreendimento, o gerente planeja como tratá-los. A aplicação das técnicas de resposta ao risco é antecedida pela determinação da expectativa do custo do Projeto, o que deve ser feito da forma a mais acurada possível. É importante lembrar que a determinação do custo depende da informação tratada de forma seletiva. A classificação adotada orientará o acompanhamento e controle da execução do Projeto.

A definição do custo do empreendimento necessita de premissas, das quais se destacam as seguintes:

- O levantamento das quantidades dos principais serviços a serem executados deve ser fidedigno;

- As produtividades adotadas para composição analítica dos custos unitários dos serviços devem refletir o método e o prazo de execução planejados;

- A adoção de perdas deve considerar as imprecisões usuais dos processos construtivos; e

- Não se deve considerar nenhuma contingência.

Thompson e Perry (1998) consideram que na alocação de riscos devem ser levados em conta os seguintes princípios básicos:

- Cada fator de risco tem um custo correspondente, que precisa ser identificado e assumido por algum agente, em alguma fase do ciclo de vida do projeto;

- O risco deve pertencer ao agente mais capacitado a suportar o seu impacto;

- Não se deve esperar que nenhum agente assuma riscos desproporcionais à sua expectativa de resultado;

- Muitos riscos de um empreendimento devem ser compartilhados entre os seus agentes;

- Em qualquer empreendimento, o risco residual ${ }^{29}$ deve ser suportado pelo seu proprietário.

As principais técnicas de resposta aos fatores de risco percebidos são: (a) exclusão, (b) transferência, (c) mitigação e (d) aceitação.

29 A norma ABNT ISO/IEC Guia 73 (2005) define risco residual como "risco remanescente após o tratamento do risco", e tratamento de risco, como "processo de seleção e implementação de medidas para modificar um risco". 


\section{a) Exclusão.}

Exclui-se o fator de risco que não é significativo, ou não se aplica à situação em estudo. $O$ risco excluído passa a integrar a estratégia de proposta. Previne-se a ameaça representada pelo fator de risco, planejando ações que eliminem as suas causas, por exemplo, executando obras ou serviços auxiliares. Nesse caso, as providências planejadas devem ser incluídas no orçamento do custo do empreendimento.

\section{b) Transferência.}

As técnicas mais comuns de transferência de risco são as seguintes, observados os princípios de alocação mencionados anteriormente:

- Transferência à outra parte do contrato, ao sócio, ou ao futuro subcontratado, mediante mecanismos contratuais, lembrando que a transferência implica um custo adicional, especialmente em se tratando de subcontratados;

- Transferência a terceiros, mediante a contratação de seguros e garantias. Os custos dessas contratações devem fazer parte do orçamento de custo do empreendimento.

\section{c) Mitigação.}

Significa reduzir o impacto e/ou a probabilidade de ocorrência do fator de risco até um limite considerado aceitável. É possível mitigar riscos através da adoção de um novo curso de ação que reduza o problema - por exemplo, adotando-se processos menos complexos, conduzindo mais testes sísmicos ou de engenharia ou ainda escolhendo um fornecedor mais estável. Pode-se também alterar as condições para que a probabilidade de ocorrência do risco seja reduzida - por exemplo, adicionando recursos ou tempo ao cronograma. (PMI, 2002).

A qualificação e o condicionamento da proposta constituem outra maneira de mitigação de riscos. Ambas as técnicas são diretamente afetadas pelo regime de execução do contrato e pela natureza do objeto a ser executado. Exigem, para serem praticadas, o pleno conhecimento do ambiente em que se insere o projeto em estudo.

Na prática, é sutil a diferença entre uma técnica e a outra. Qualificaşão é o ato de esclarecer pontos fundamentais da proposta, com o intuito de delimitar e/ou definir com mais precisão o seu 
conteúdo. A qualificação se dá pelo registro de procedimentos planejados, feito tanto por meio de texto, como de planilha de cálculo.

Já condicionamento é o ato de fazer ressalvas visando garantir direitos e/ou prevenir responsabilidades. O condicionamento é feito por intermédio da instituição de novas condições ou pela restrição de requisitos existentes.

\section{d) Aceitação.}

A maneira mais comum de aceitar o risco é constituir um fundo de reserva para contingência, a ser utilizado caso os riscos aconteçam. O pressuposto é não utilizar essa reserva, ou utilizá-la parcialmente, adicionando-a ao resultado econômico desejado da execução do empreendimento. $\mathrm{Na}$ formação do preço final de venda, a contingência não tem influência nas contas gerais de administração do empreendimento, exceto se durante a execução houver alterações no prazo. A contingência não faz parte do orçamento da obra.

O cálculo da contingência não é um processo exato, exigindo, além de critério apurado, sensibilidade e experiência por parte de quem o elabora, devendo ser feito de forma individualizada, isto é, para cada um dos fatores de risco e não pelo total do seu valor.

\subsection{SURGIMENTO DO PLANO DE ADMINISTRAÇÃO CONTRATUAL}

Para proceder às etapas de planejamento, identificação e avaliação de riscos de execução de projetos da construção pesada, e formular o correspondente plano de resposta, o Gerente promove um amplo debate, envolvendo os integrantes da sua equipe de gerenciamento e especialistas convidados.

O debate é essencial, pois refina o processo, consolida informações e compõe o planejamento das ações dos interessados diretos no projeto, formando um sistema íntegro que permite a atribuição de responsabilidades. Concluído o debate, o integrante da equipe de gerenciamento designado para administrar o contrato, resume e registra as conclusões havidas a respeito dos riscos percebidos e de como enfrentá-los, organizando os dados para que constituam as diretrizes de um plano. 
Esse plano reflete a posição qualificada de toda a equipe de gerenciamento sobre o assunto, expressando o compromisso de cada integrante com as metas traçadas, bem como propicia ao gerente do projeto a base sólida que necessita para apresentar à parte compradora a melhor proposta - isto é, a mais equilibrada. Além disso, o plano fornece as premissas para programar a futura Administração do Contrato, caso sua proposta seja a vencedora da licitação, e o contrato venha a ser assinado.

O processo proporciona visão abrangente da futura execução e administração do contrato. Funciona como uma agenda de compromissos entre o gerente e a equipe de gerenciamento do projeto, facilitando a comunicação entre todos os integrantes, porque reflete as decisões estratégicas tomadas em resposta às seguintes perguntas:

- Qual a melhor forma de executar tecnicamente o projeto?

- Quais as oportunidades e os riscos percebidos, e como foram tratados?

- Quais os principais riscos tomados?

- Quais os possíveis pontos de conflito na relação entre as partes contratante e contratada, na execução do projeto?

Planejamento executivo de engenharia; orçamento do custo; identificação, avaliação e respostas aos riscos; e formação do preço de venda, são atividades integradas, que compõem um só sistema, de fluxo e refluxo, cujo mapa está apresentado na Figura 4.3. Concluído o debate, as conclusões são lançadas numa matriz, como a esquematizada no Quadro 4.1. Nela, cumpre observar que:

- A coluna "Fatores de risco" é preenchida com base no exame dos elementos citados no parágrafo anterior. Listas de verificação (“checklists") ${ }^{30}$ podem constituir instrumentos úteis ao trabalho de identificação de fatores de risco;

- A coluna "Considerações" registra os critérios utilizados na elaboração do orçamento de custo e na alocação de riscos, discutidos no item 4.3 do Capítulo 4. Esses critérios alicerçam a estimativa e avaliação de cada fator de risco, expressas nas colunas "A" até "C" da matriz, bem como resumem a justificativa do tratamento que lhes foi dado, refletido no preenchimento das colunas "D" até "I"; e

\footnotetext{
30 A título de exemplos, citam-se entre outros, os “checklists" elaborados por: (a) ROCHA (2005), para obras públicas de infra-estrutura urbana; (b) BRAMBLE; D'ONOFRIO; STETSON (1990), para obras de infraestrutura em geral; e (c) ANDRIOLO; MAIONCHI; RICARDINO (2000), para Projetos hidrelétricos.
} 
- O valor resultante do somatório da coluna "I" equivale a um fundo de reserva para execução do Projeto, a ser utilizado caso os riscos identificados venham a acontecer.

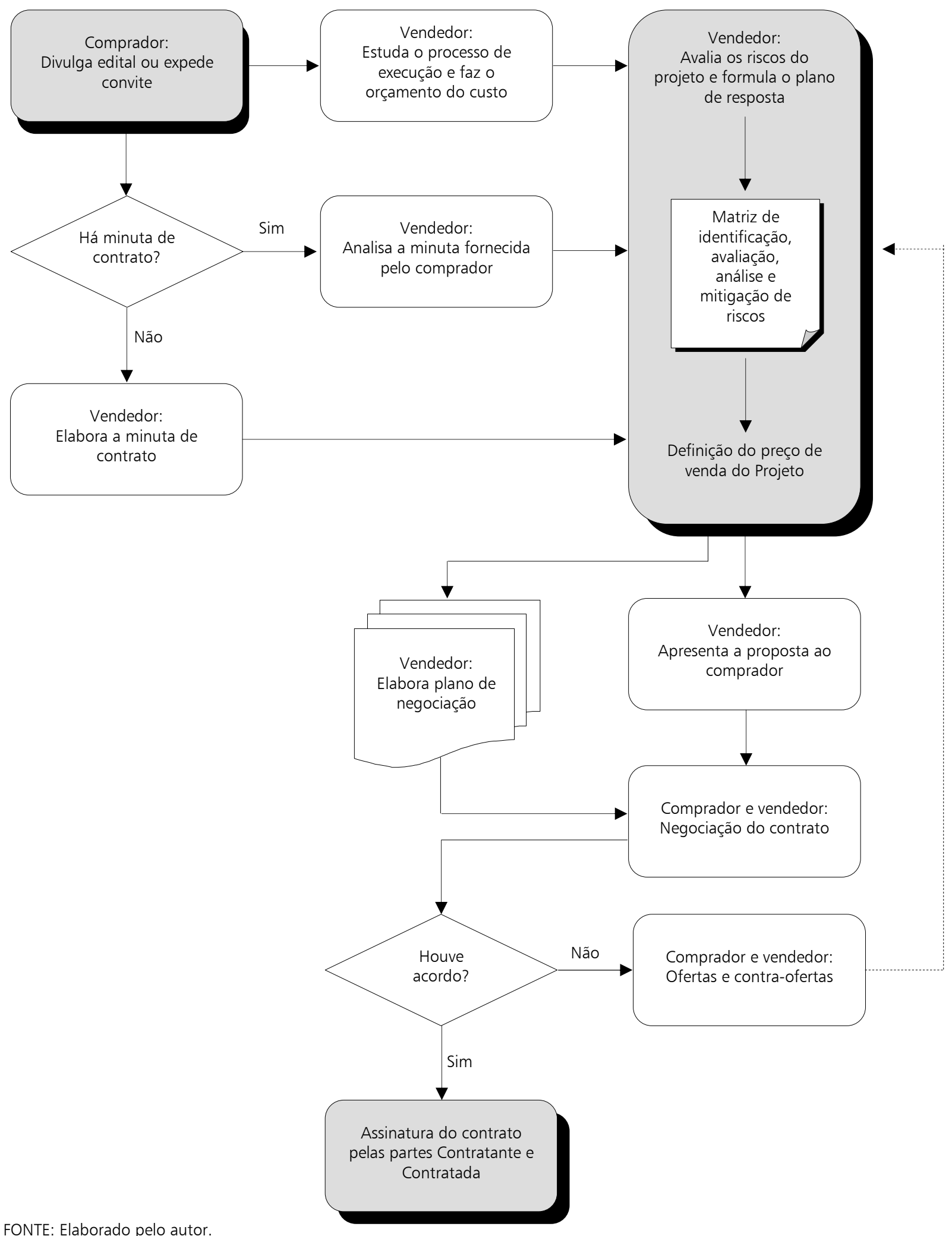

FONTE: Elaborado pelo autor.

Figura 4.3 - Mapa do planejamento da administração contratual. 


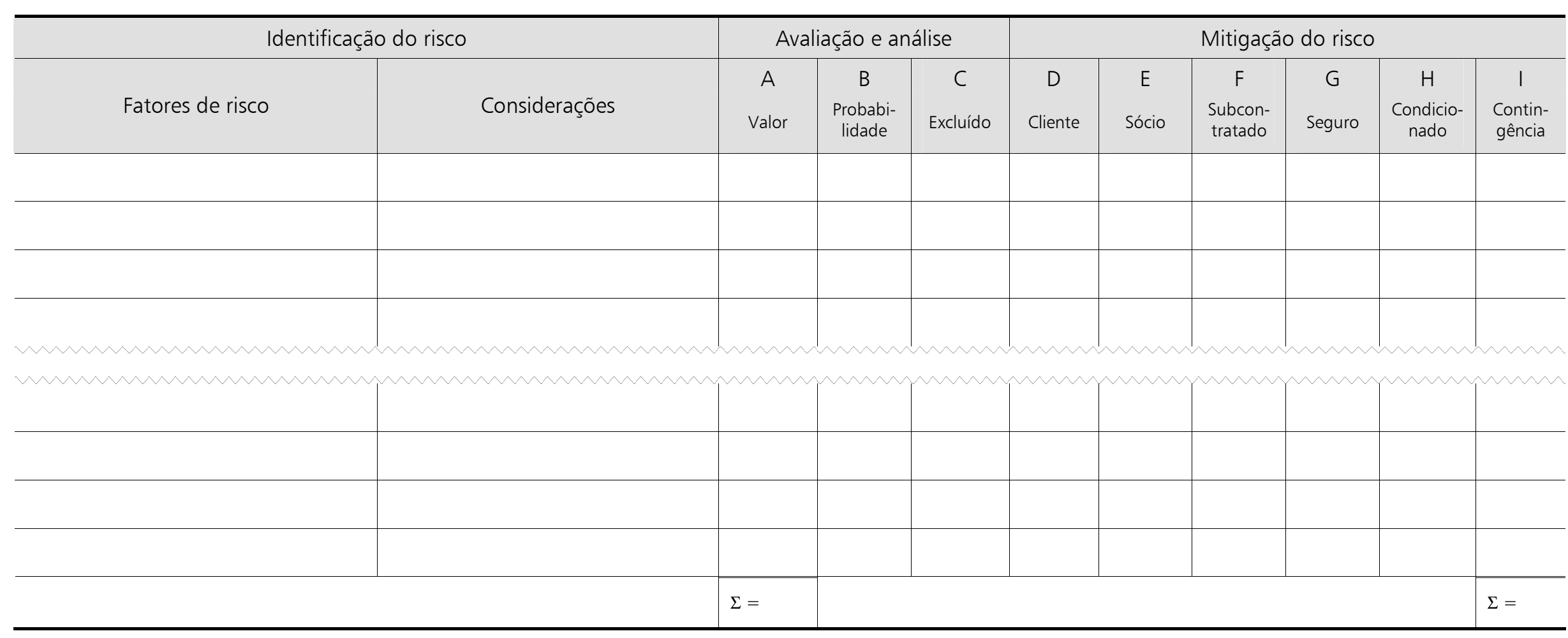

FONTE: $\quad$ Elaborado pelo autor, a partir de Andriolo; Maionchi; Ricardino (2000).

$\begin{aligned} & \text { LEGENDA: } \text { A - Valor: } \\ & \text { B - Probabilidade: } \\ & \text { C - Excluído: } \\ & \text { D - Cliente: } \\ & \text { E - Sócio: } \\ & \text { F - Subcontratado: } \\ & \text { G - Seguro: } \\ & \text { H - Condicionado: } \\ & \text { I - Contingência: }\end{aligned}$

Valor estimado para o impacto causado pela ocorrência singular do risco.

Probabilidade de ocorrência do risco (em porcentagem)

Fator de risco excluído por não ser significativo, ou não ser aplicável ao caso em estudo.

Risco no escopo do cliente, ou transferido ao cliente por intermédio de mecanismos contratuais.

Risco transferido a uma empresa integrante do consórcio.

Risco transferido a fornecedor de bens ou prestador de serviços.

Risco transferido a uma terceira parte, mediante a contratação de apólice de seguro.

Risco qualificado e/ou condicionado na proposta apresentada ao cliente.

Valor incorporado ao preço de venda ofertado ao cliente.

Quadro 4.1 - Matriz de planejamento de respostas a riscos 


\section{APRESENTAÇÃO DOS ESTUDOS DE CASO REALIZADOS}

\subsection{CONSIDERAÇÕES SOBRE O QUESTIONÁRIO DA PESQUISA}

No Capítulo 1 - "Introdução" deste trabalho destacou-se que, nos contratos do setor da construção pesada, a maioria dos problemas decorrentes de eventos geradores de disputas pode ser evitada, ou resolvida, mediante a utilização dos preceitos da gestão de empreendimentos e, também, ressaltou-se que tais problemas são afetados por fatores técnicos e pelo comportamento humano.

Os principais aspectos de gestão, influentes no processo de Gerenciamento de Projetos e, em decorrência, no de Administração de Contrato, são examinados por intermédio da realização de dois Estudos de Caso, nesta dissertação designados de Estudo de Caso 1 ("EC-1") e Estudo de Caso 2 ("EC-2").

Os Estudos de Caso obedeceram ao propósito de explorar um conjunto referencial de fatores e habilidades de gerenciamento, preconizado no Capítulo 3 deste trabalho, investigando-o por dois prismas distintos: o da parte Contratante e o da parte Contratada, por meio do levantamento extensivo, por amostragem, das práticas de duas importantes organizações brasileiras, previamente identificadas, conforme descrito no item 5.2 deste Capítulo.

Para esse fim elaborou-se um único conjunto de questões substantivas ("questionário"), aplicado a Gerentes das duas organizações com o intuito de conhecer seus pontos de vista sobre os fatores mais importantes às práticas das administrações de projetos e de contratos, bem como as habilidades que mais influem nessas práticas. O questionário utilizado para a coleta de dados consta do APÊNDICE A.

A estrutura geral do questionário, apresentada na Tabela 5.1, mostra sua organização em 16 grupos de perguntas (“Quesitos”), numerados de 1 a 16, distribuídos em 4 seções. Do total das 192 perguntas, a maioria (93\%) é de formato fechado, e as demais são de formato aberto. Segundo Rea e Parker (2000, p. 44), as perguntas de formato fechado "fornecem uma lista fixa de alternativas de resposta e pedem que o entrevistado selecione uma ou mais como indicativa da 
melhor resposta possível. Em contraste, as perguntas abertas não possuem categorias pré-fixadas de respostas e dão ao entrevistado ampla liberdade para respondê-las".

Tabela 5.1 - Estrutura do questionário aplicado aos Estudos de Caso.

\begin{tabular}{|c|c|c|c|}
\hline \multicolumn{2}{|r|}{ Quesitos e seções do questionário } & $\begin{array}{l}\text { Perguntas de } \\
\text { formato }\end{array}$ & $\begin{array}{l}\text { Perguntas de } \\
\text { formato }\end{array}$ \\
\hline \multicolumn{4}{|c|}{ SEÇÃO I - PERFIL DOS ENTREVISTADOS } \\
\hline 1 & Formação profissional & 5 & 1 \\
\hline 2 & Tempo de experiência profissional & 6 & 0 \\
\hline 3 & Tempo de lotação em canteiros de obras & 6 & 0 \\
\hline 4 & Regime de execução de contratos de que participa ou participou & 4 & 1 \\
\hline \multirow[t]{2}{*}{5} & Tempo de experiência em Administração de Contrato & 8 & 0 \\
\hline & SEÇÃO II - APRENDIZADO DA ADMINISTRAÇÃO DE CONTRATO & & \\
\hline \multirow[t]{2}{*}{6} & Meios de aprendizagem em Administração de Contrato & 6 & 1 \\
\hline & SEÇÃO III - GERENCIAMENTO DE PROJETOS & & \\
\hline 7 e 8 & Fatores que mais influem no Gerenciamento de Projetos & 16 & 1 \\
\hline 9 e 10 & Habilidades técnicas do gerente, que mais influem no Gerenciamento de Projetos & 18 & 1 \\
\hline \multirow[t]{2}{*}{11 e 12} & Habilidades pessoais do gerente, que mais influem no Gerenciamento de Projetos & 12 & 1 \\
\hline & SEÇÃO IV - ADMINISTRAÇÃO DE CONTRATO & & \\
\hline 13 e 14 & Requisitos que mais influem na prática da Administração de Contrato & 14 & 1 \\
\hline 15 e 16 & Fatores que afetam o atendimento de reivindicação contratual & 12 & 1 \\
\hline
\end{tabular}

OBSERVAÇÃO: No questionário, as perguntas de formato aberto são caracterizadas pela opção "Outros".

Os Quesitos 1 a 5 do questionário foram formulados pelo autor com o propósito de se traçar o perfil dos entrevistados, e o Quesito 6, de conhecer a sua opinião sobre os meios de aprendizagem do processo de Administração de Contrato. Os Quesitos 7 a 12, relativos aos principais fatores e habilidades que influenciam o Gerenciamento de Projetos, e os Quesitos 13 e 14, abordando os aspectos mais influentes na prática da Administração de Contrato, foram elaborados a partir de Wysocki e Lewis (2000); Dinsmore e Silveira Neto (2005). Os Quesitos 15 e 16, referentes a reivindicações contratuais, foram fixados com base em McManus; Jentzen; Greenberg (1996) e em outros levantamentos realizados pelo autor da dissertação, anteriormente 
aos desta pesquisa. Os Quadros 5.1 a 5.5 mostram o conjunto referencial de fatores e habilidades considerados nos Quesitos 7 a 16 do questionário, assinalando a respectiva correlação com a Administração de Contrato e sua interface com o gerenciamento de riscos, ou seja, com o referencial teórico desenvolvido nos capítulos anteriores.

\begin{tabular}{|c|c|c|}
\hline Fatores que mais influem no Gerenciamento de Projetos & $\begin{array}{c}\text { Administração } \\
\text { de Contrato }\end{array}$ & $\begin{array}{c}\text { Interface com } \\
\text { risco }\end{array}$ \\
\hline Abrangência do escopo & $\diamond$ & $\bullet$ \\
\hline Acompanhamento e avaliação progressiva & $\bullet$ & \\
\hline Aquisição de materiais de construção & $\diamond$ & \\
\hline Avaliação estratégica da complexidade & & $\diamond$ \\
\hline Caminho crítico da gestão & & $\diamond$ \\
\hline Memória técnica da execução & $\diamond$ & \\
\hline Designação das pessoas da equipe & & $\diamond$ \\
\hline Detalhamento da estimativa & & $\diamond$ \\
\hline Estimativa do custo & & $\diamond$ \\
\hline Finalização do projeto & $\diamond$ & \\
\hline Gestão do custo & $\bullet$ & \\
\hline Organização do projeto & & $\diamond$ \\
\hline Planejamento do projeto & & $\diamond$ \\
\hline Produtividade da mão de obra de execução & $\bullet$ & $\diamond$ \\
\hline Produtividade na operação de equipamentos & $\diamond$ & $\diamond$ \\
\hline Software para gerenciamento do projeto & $\diamond$ & \\
\hline
\end{tabular}

Fonte: Elaborado pelo autor.

Quadro 5.1 - Conjunto referencial dos Quesitos 7 e 8.

\begin{tabular}{|c|c|c|}
\hline $\begin{array}{l}\text { Habilidades técnicas do gerente, que mais influem no } \\
\text { Gerenciamento de Projetos }\end{array}$ & $\begin{array}{l}\text { Administração } \\
\text { de Contrato }\end{array}$ & $\begin{array}{l}\text { Interface com } \\
\text { risco }\end{array}$ \\
\hline Administração simultânea de múltiplas prioridades & $\diamond$ & \\
\hline Ajuste do estilo de liderança ao longo da execução & $\diamond$ & \\
\hline Avaliação do empreendimento como um todo & $\diamond$ & $\diamond$ \\
\hline Conceito das funções do processo de gestão & $\diamond$ & $\diamond$ \\
\hline Conhecimento das próprias forças e fraquezas & $\diamond$ & $\diamond$ \\
\hline Delegação & $\diamond$ & \\
\hline Desempenho (método de trabalho) do gerente & $\diamond$ & \\
\hline Desenvolvimento das pessoas & $\diamond$ & \\
\hline Escolha da melhor maneira de orçar & & $\diamond$ \\
\hline Estratégia & $\diamond$ & $\diamond$ \\
\hline
\end{tabular}

(Continua) 
(Conclusão)

\begin{tabular}{|c|c|c|}
\hline $\begin{array}{l}\text { Habilidades técnicas do gerente, que mais influem no } \\
\text { Gerenciamento de Projetos }\end{array}$ & $\begin{array}{l}\text { Administração } \\
\text { de Contrato }\end{array}$ & $\begin{array}{l}\text { Interface com } \\
\text { risco }\end{array}$ \\
\hline Integração da equipe & $\diamond$ & $\diamond$ \\
\hline Liderança & $\diamond$ & $\diamond$ \\
\hline Necessidades do Cliente & $\diamond$ & $\bullet$ \\
\hline Procedimentos e políticas & $\diamond$ & \\
\hline Reuniões periódicas & $\diamond$ & \\
\hline Seleção e mobilização da equipe & $\diamond$ & $\bullet$ \\
\hline Tática & $\diamond$ & \\
\hline Visão da oportunidade & $\diamond$ & $\bullet$ \\
\hline
\end{tabular}

Fonte: Elaborado pelo autor.

Quadro 5.2 - Conjunto referencial dos Quesitos 9 e 10.

\begin{tabular}{|c|c|c|}
\hline $\begin{array}{c}\text { Habilidades pessoais do gerente, que mais influem no } \\
\text { Gerenciamento de Projetos }\end{array}$ & $\begin{array}{l}\text { Administração } \\
\text { de Contrato }\end{array}$ & $\begin{array}{l}\text { Interface com } \\
\text { risco }\end{array}$ \\
\hline Comunicação escrita & $\diamond$ & $\diamond$ \\
\hline Comunicação verbal & $\diamond$ & \\
\hline Criatividade & $\diamond$ & $\diamond$ \\
\hline Estimulador/ Educador de pessoas & $\diamond$ & \\
\hline Flexibilidade & $\diamond$ & \\
\hline Influenciador & $\diamond$ & $\diamond$ \\
\hline Negociação & $\diamond$ & $\diamond$ \\
\hline Objetividade e clareza em apresentar/oferecer & $\diamond$ & \\
\hline Pensamento crítico/ Tomada de decisão & $\diamond$ & $\diamond$ \\
\hline Sociabilidade & $\diamond$ & \\
\hline Solução de conflitos & $\diamond$ & $\diamond$ \\
\hline Solução de problemas técnicos & $\diamond$ & $\diamond$ \\
\hline
\end{tabular}

Fonte: Elaborado pelo autor.

Quadro 5.3 - Conjunto referencial dos Quesitos 11 e 12.

\begin{tabular}{l|c|c}
\hline Requisitos que mais influem na Administração de Contrato & $\begin{array}{c}\text { Administração } \\
\text { de Contrato }\end{array}$ & $\begin{array}{c}\text { Interface com } \\
\text { risco }\end{array}$ \\
\hline Apoio jurídico & $\bullet$ \\
Competência na negociação & $\bullet$ \\
Compreensão da base legal & $\bullet$ \\
Compreensão da base técnica & $\bullet$ \\
Conhecimento sobre o Cliente & $\bullet$ \\
Coordenação de interfaces & $\bullet$
\end{tabular}


(Conclusão)

\begin{tabular}{l|c|c}
\hline Requisitos que mais influem na Administração de Contrato & $\begin{array}{c}\text { Administração } \\
\text { de Contrato }\end{array}$ & $\begin{array}{c}\text { Interface com } \\
\text { risco }\end{array}$ \\
\hline Documentação e arquivo & $\bullet$ \\
Domínio do escopo do contrato & $\bullet$ \\
Equipe qualificada & $\bullet$ \\
Integração de atividades multifuncionais & $\bullet$ \\
Liderança & $\bullet$ \\
Orçamento como conseqüência do planejamento & $\bullet$ \\
Postura ganha-ganha & $\bullet$
\end{tabular}

Fonte: Elaborado pelo autor.

Quadro 5.4 - Conjunto referencial dos Quesitos 13 e 14.

\begin{tabular}{|c|c|c|}
\hline $\begin{array}{l}\text { Fatores que afetam o atendimento de reivindicação } \\
\text { contratual }\end{array}$ & $\begin{array}{l}\text { Administração } \\
\text { de Contrato }\end{array}$ & $\begin{array}{l}\text { Interface com } \\
\quad \text { risco }\end{array}$ \\
\hline Ambiente no canteiro de obra & $\diamond$ & \\
\hline Clareza do texto & $\diamond$ & \\
\hline Documentação de suporte & $\diamond$ & \\
\hline Domínio do Projeto por parte do Gerente da empresa & $\diamond$ & $\diamond$ \\
\hline Domínio do Projeto por parte da equipe do Gerente & $\diamond$ & $\diamond$ \\
\hline Existência de registro dos fatos ocorridos & $\diamond$ & \\
\hline Fundamentação legal da reivindicação & $\diamond$ & \\
\hline Fundamentação técnica da reivindicação & $\diamond$ & \\
\hline Momento do Projeto & $\diamond$ & \\
\hline Pontualidade no cumprimento do cronograma físico & $\diamond$ & $\diamond$ \\
\hline Procedimento de decisão da outra parte & $\diamond$ & \\
\hline Qualidade da execução do Projeto & $\diamond$ & \\
\hline
\end{tabular}

Fonte: Elaborado pelo autor.

Quadro 5.5 - Conjunto referencial dos Quesitos 15 e 16.

\subsection{CONDUÇÃO DOS LEVANTAMENTOS DE CAMPO.}

Para realizar os Estudos de Caso, foram identificadas duas importantes organizações brasileiras, ambas com forte presença no setor da construção pesada de infra-estrutura aeroportuária. $\mathrm{O}$ acesso às organizações foi feito por meio de entrevistas exploratórias, destinadas a calibrar a base amostral, a partir da sua cobertura completa, seguidas de Cartas de Apresentação emitidas pelo Departamento de Engenharia de Construção Civil da EPUSP. 
O Estudo de Caso 1 foi efetuado junto a empresa pública contratante de empreendimentos de infra-estrutura aeroportuária, e o Estudo de Caso 2 em empresa privada, atuante na execução de empreendimentos do setor da construção pesada, no Brasil e também em diversos outros países. Para os efeitos da dissertação, o EC-1 reflete o ponto de vista da parte compradora ou Contratante, e o EC-2, o da parte vendedora ou Contratada. Em ambos os Casos, a população ou universo estatístico da pesquisa constitui-se de gerentes, atuantes em canteiros de obras ou nos escritórios das organizações às quais se achavam vinculados. Para o objetivo da pesquisa, o termo Gerente serviu para designar os responsáveis pela implantação ou execução tanto de um Projeto completo, como por frações que o compõem.

À época do planejamento do questionário, os tamanhos dos universos da pesquisa não puderam ser determinados com exatidão, em face da dispersão geográfica dos entrevistados, nos dois Casos. As entrevistas exploratórias mencionadas no parágrafo anterior possibilitaram a avaliação do número de entrevistados: 100 Gerentes no Estudo de Caso 1 e 120 no Estudo de Caso 2, tendo-se admitido uma oscilação de $5 \%$, para mais e para menos.

O questionário foi enviado em mídia impressa às organizações onde a pesquisa teve lugar. Em devolução, foram recebidos 75 questionários no Estudo de Caso 1, e 66 no Estudo de Caso 2. Em cada Caso, 5 questionários revelaram-se totalmente inválidos e por esse motivo tiveram que ser descartados, daí resultando uma amostra válida de 70 questionários no Estudo de Caso 1, e de 61 no Estudo de Caso 2. Considerando o tamanho do universo da pesquisa no caso mais desfavorável, a margem de erro amostral, com 5\% de confiança, é de 6,8\% no Estudo de Caso 1 e de $9 \%$ no Estudo de Caso 2, conforme demonstrativo de cálculo constante do APÊNDICE B desta dissertação. O Quadro 5.6 apresenta uma síntese das informações dadas anteriormente, fornecendo uma visão geral do processo de coleta de dados da pesquisa.

\begin{tabular}{l|c|c}
\multicolumn{1}{c|}{ Descrição } & Estudo de Caso 1 & Estudo de Caso 2 \\
\hline $\begin{array}{l}\text { Organização junto à qual foi realizado o } \\
\text { Estudo de Caso }\end{array}$ & $\begin{array}{c}\text { Empresa pública brasileira, } \\
\text { contratante de Projetos }\end{array}$ & $\begin{array}{c}\text { Empresa privada brasileira, } \\
\text { executora de Projetos }\end{array}$ \\
$\begin{array}{l}\text { Período de coleta de dados, da data do envio à data da } \\
\text { devolução de questionários }\end{array}$ & $13 / 02 / 2006$ a 11/04/2006 & $29 / 05 / 2006$ a 08/08/2006 \\
$\begin{array}{l}\text { Tamanho estimado do universo da pesquisa à época do } \\
\text { seu planejamento }\end{array}$ & 100 Gerentes \\
$\begin{array}{l}\text { Variação admitida do tamanho do universo da pesquisa } \\
( \pm 5 \%)\end{array}$ & 95 a 105 Gerentes \\
(Continua) & & 114 a 126 Gerentes
\end{tabular}


(Conclusão)

\begin{tabular}{l|cc}
\hline \multicolumn{1}{c|}{ Descrição } & Estudo de Caso 1 & Estudo de Caso 2 \\
\hline Questionários recebidos em devolução & 75 & 66 \\
$\begin{array}{l}\text { Questionários recebidos que foram considerados } \\
\text { totalmente inválidos e descartados }\end{array}$ & 5 & 51 \\
$\begin{array}{l}\text { Tamanho da amostra } \\
\text { Margem de erro amostral do caso mais desfavorável, no } \\
\text { nível de confiança de 95\% }\end{array}$ & 70 & $9,0 \%$ \\
\hline
\end{tabular}

Fonte: Elaborado pelo autor.

Quadro 5.6 - Aspectos da aplicação do questionário aos Estudos de Caso.

\subsection{PERFIL DOS ENTREVISTADOS}

Neste e no item seguinte do Capítulo 5, são comentados os resultados obtidos na apuração das respostas aos 16 Quesitos do questionário aplicado aos Estudos de Caso 1 e 2. Inicialmente, é delineado o perfil do público-alvo da pesquisa, por meio da apresentação das respostas às seguintes perguntas: (a) formação e experiência profissional dos entrevistados, abrangendo os Quesitos 1, 2 e 3 do questionário; (b) experiência dos entrevistados em Administração de Contrato, envolvendo os Quesitos 4 e 5; e (c) meios de aprendizagem da Administração de Contrato, compreendendo o Quesito 6.

No APENNDICE C deste trabalho apresentam-se, sob forma tabular, as respostas dadas pelos entrevistados ao questionário utilizado nos Estudos de Caso 1 e 2. Para a tabulação dos Quesitos 6 a 16 do questionário, e estabelecimento da hierarquia das respectivas variáveis componentes, foram aplicados dois critérios distintos.

- Quesitos 6, 7, 9, 11, 13 e 15: inicialmente, foram computadas as respostas dadas a cada opção (variável) desses Quesitos. A seguir, em cada Quesito aplicou-se à opção indicada em $1^{\circ}$ lugar, o número de pontos correspondente à quantidade total (“q”) de opções do Quesito; à opção indicada em $2^{\circ}$ lugar, o número de pontos correspondente a [q-1]; e assim sucessivamente, até que fosse atribuído 1 ponto à opção indicada em último lugar. A hierarquia das opções de cada Quesito foi determinada pelo somatório dos pontos resultantes da aplicação do critério.

- Quesitos 8, 10, 12, 14 e 16: foram computados os pontos atribuídos pelos entrevistados a cada opção desses Quesitos, em conformidade com a graduação pré-fixada no 
questionário. A hierarquia das opções de cada Quesito foi determinada pelo somatório dos pontos atribuídos a cada opção do Quesito.

\section{a) Formação e experiência profissional dos entrevistados.}

No que tange ao Quesito 1 do questionário, 88\% do total da amostra do Estudo de Caso 1 compõem-se de engenheiros $(69 \%)$ e de arquitetos (19\%), distribuindo-se o restante da amostra em 8 outras formações profissionais. No Estudo de Caso 2, os engenheiros representam $85 \%$ do total da amostra, estando o restante da amostra distribuída entre administradores (5\%), contadores $(5 \%)$ e 3 outras formações profissionais. ${ }^{31}$

Quanto ao Quesito 2, a Figura 5.1 mostra como se distribui o tempo de experiência profissional dos participantes, apontando, no Estudo de Caso 1, que 39\% dos participantes da pesquisa têm 21 anos ou mais de experiência, enquanto no Estudo de Caso 2 essa porcentagem atinge 46\%.

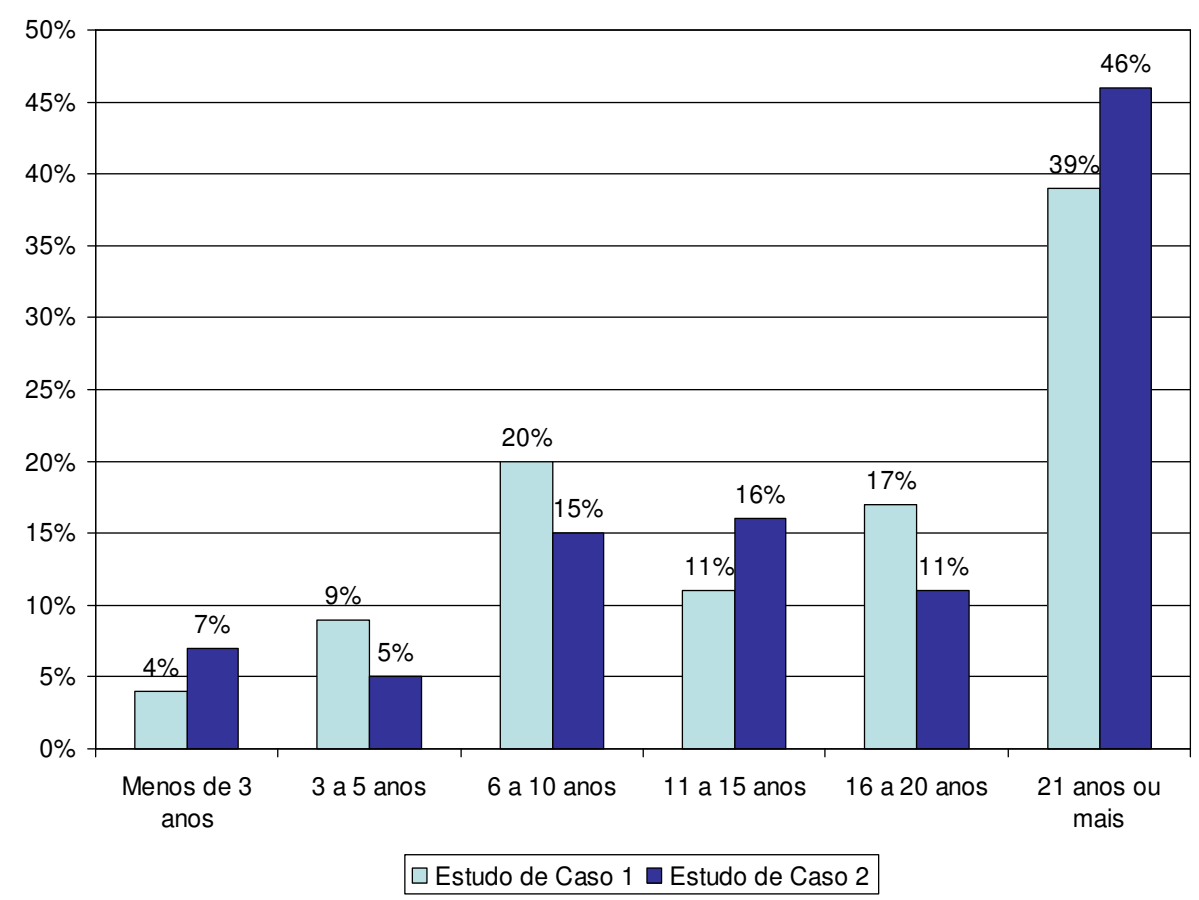

FONTE: Pesquisa do autor (Conforme Tabela C.2 do APÊNDICE C).

Figura 5.1 - Experiência profissional dos entrevistados.

\footnotetext{
31 Conforme dados da Tabela C.1 do APÊNDICE C.
} 
No que diz respeito ao Quesito 3, a Figura 5.2 expressa a distribuição da experiência dos entrevistados em trabalhar em canteiros de obras, revelando, no Estudo de Caso 1, que 13\% da amostra assinalou não ter nenhum tempo de lotação em canteiros de obras. Em se tratando do Estudo de Caso 2, esse número cai pela metade.

\section{b) Experiência dos entrevistados em Administração de Contrato.}

Quanto à tipologia de regimes de execução de contratos, pesquisada no Quesito 4 do Questionário, no Estudo de Caso 1 sobressaiu o regime misto de empreitada por preço unitário e global, com 38\% do total de indicações, e no Estudo de Caso 2 preponderou o regime de empreitada por preço unitário, com 30\% das respostas, como exibido na Figura 5.3.

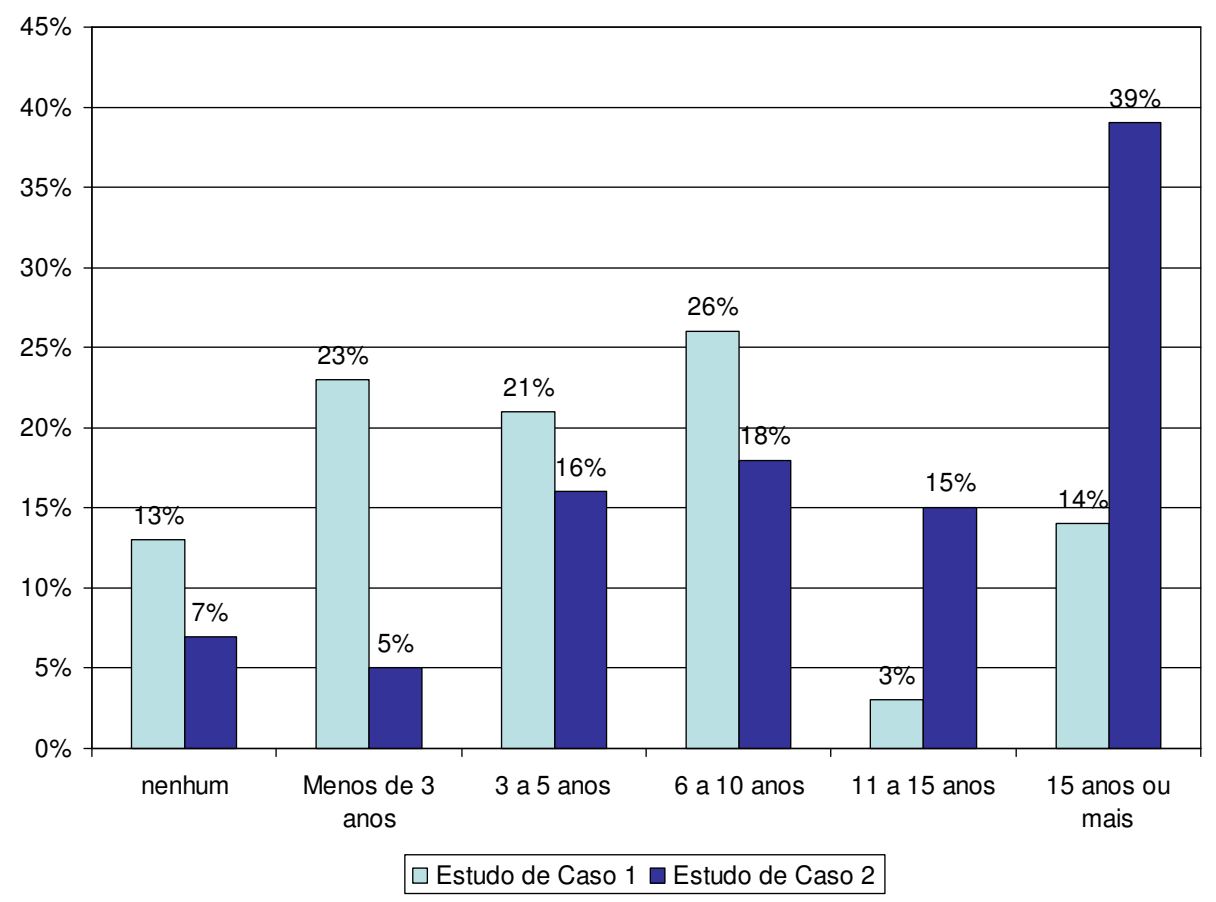

FONTE: Pesquisa do autor (Conforme Tabela C.3 do APÊNDICE C).

Figura 5.2 - Tempo de lotação em canteiros de obras.

A formulação do Quesito 4 também permite que se conheça a experiência dos entrevistados em lidar com múltiplos regimes de execução de contratos. Conforme aponta a Figura 5.4, em ambos os Estudos de Caso preponderou a experiência dos entrevistados com somente 1 tipo de contrato: 66\% das respostas no Estudo de Caso 1, e 33\% no Estudo de Caso 2. Neste último, a segunda maior freqüência de respostas (32\% de experiência com 2 regimes de execução) está muito próxima da primeira classificada. 


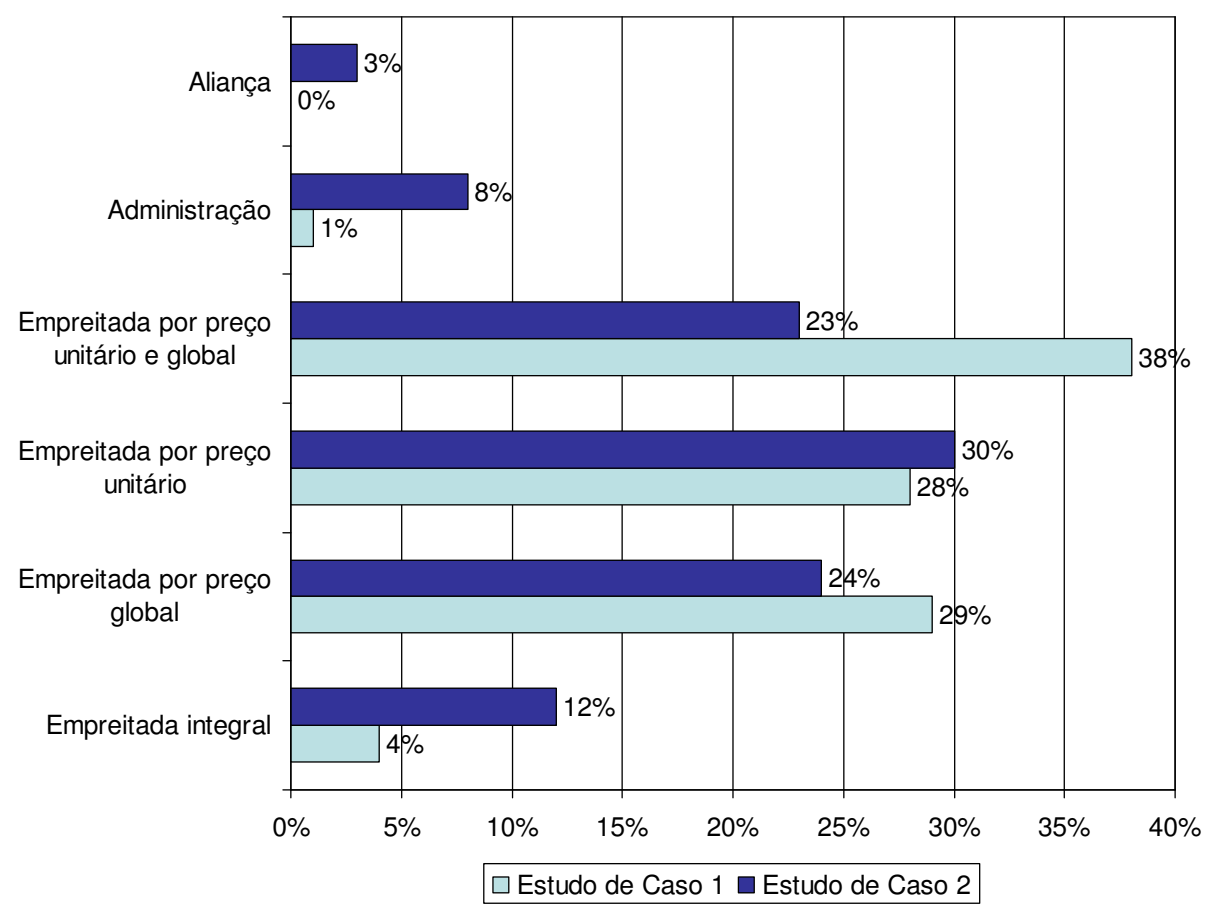

FONTE: Pesquisa do autor (Conforme Tabela C.4 do APÊNDICE C).

Figura 5.3 - Experiência com regimes de execução de contratos.

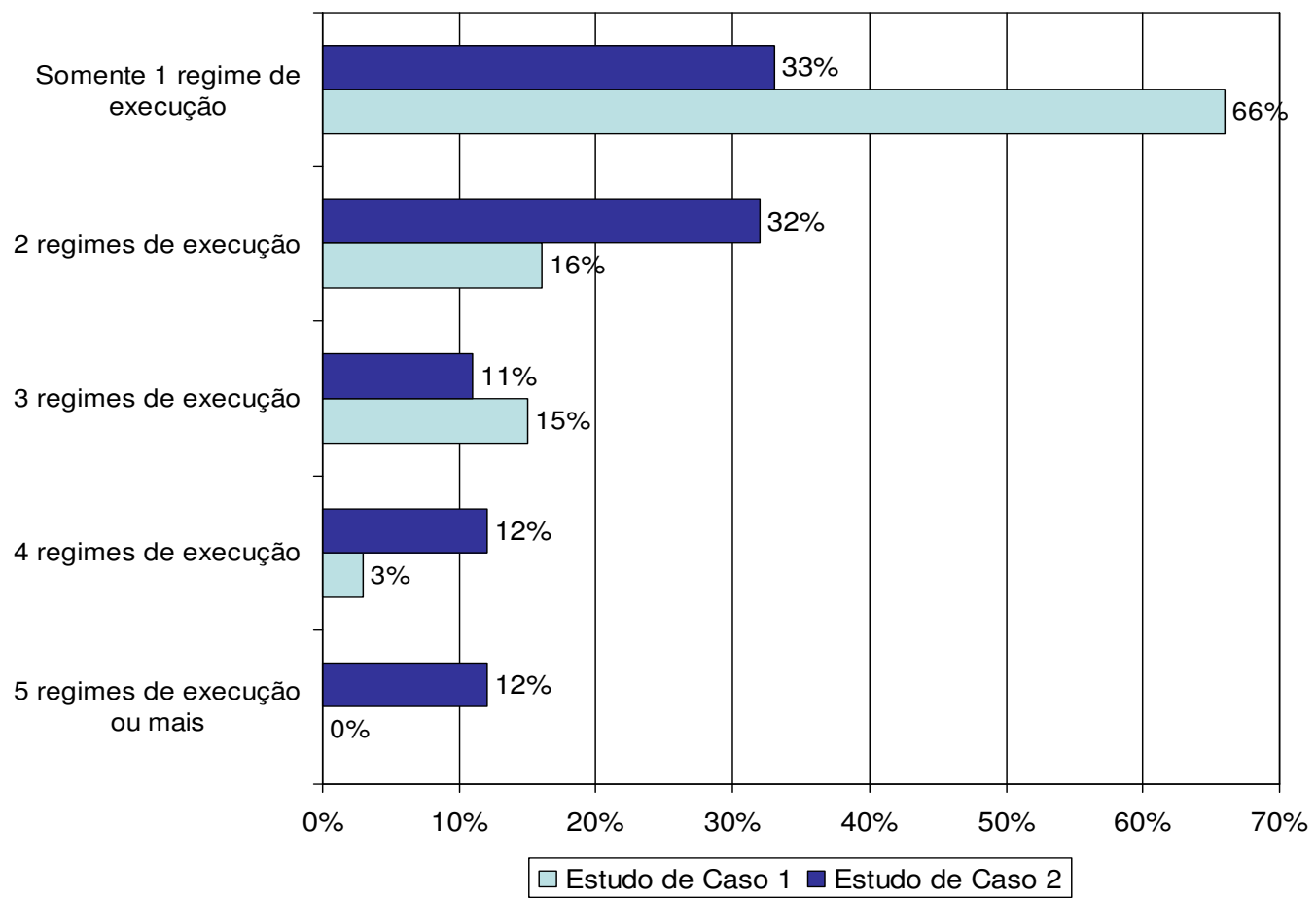

FONTE: Pesquisa do autor (Conforme Tabela C.5 do APÊNDICE C).

Figura 5.4 - Experiência com mais de um regime de execução de contratos. 
No que se refere à experiência dos entrevistados em Administração de Contrato, objeto do Quesito 5, a Figura 5.5 denota que nos dois Estudos de Caso predominou o tempo médio de 6 a 10 anos, com $27 \%$ de freqüência de respostas no EC-1 e 20\% no EC-2.

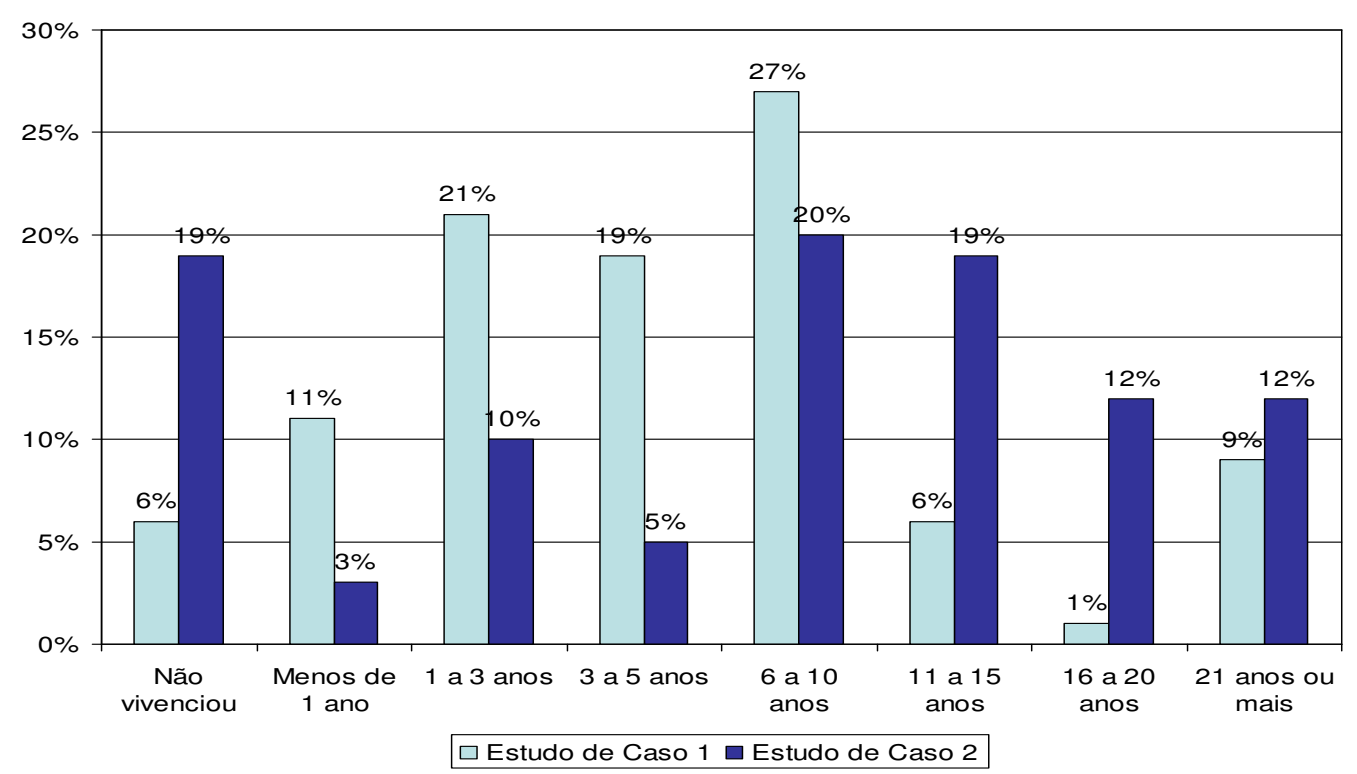

FONTE: Pesquisa do autor (Conforme Tabela C.8 do APÊNDICE C).

Figura 5.5 - Experiência em Administração de Contrato.

\section{c) Meios de aprendizagem da Administração de Contrato.}

Dentre os meios de aprendizagem da Administração de Contrato, pesquisados no Quesito 6 do Questionário, o que apresentou a maior freqüência de respostas foi o aprendizado "com base no planejamento", tanto no Estudo de Caso 1, com 22\% do total de indicações, como no Estudo de Caso 2, com 19\%. Como mostra a Figura 5.6, nos dois Estudos de Caso, os respectivos meios de aprendizagem classificados em segundo lugar encontram-se muito próximos daquele posicionado em primeiro. Isto indica, dentro do universo pesquisado, uma forte visão do aprendizado empírico para a Administração de Contratos. 


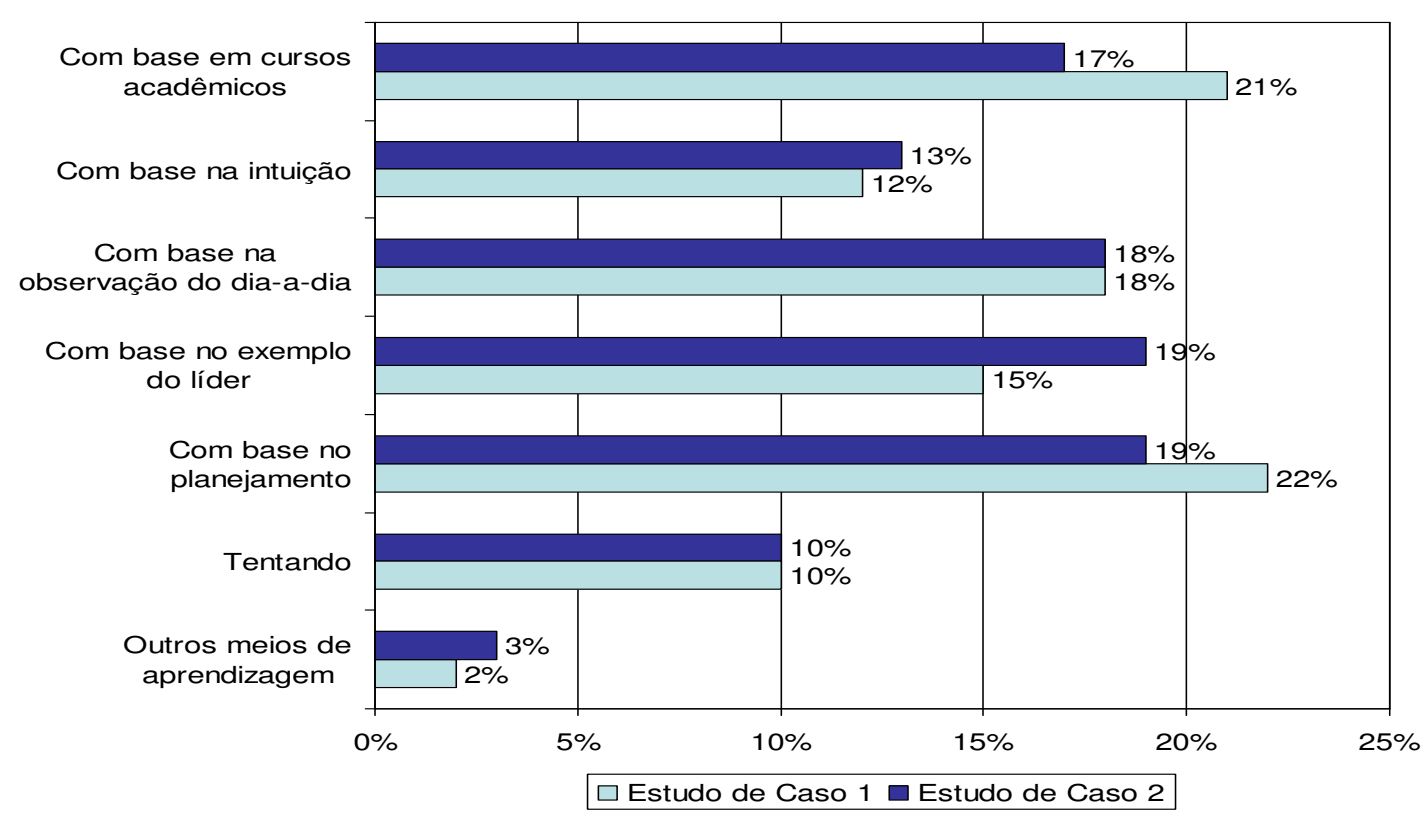

FONTE: Pesquisa do autor (Conforme Tabela C.9 do APÊNDICE C).

Figura 5.6 - Meios de aprendizagem em Administração de Contrato.

\subsection{RESULTADOS DOS ESTUDOS DE CASO REALIZADOS}

O propósito do item 5.4 é apresentar os resultados dos Quesitos 7 a 16 do questionário da pesquisa e discutir os aspectos mais relevantes dos dados obtidos. A discussão é feita, para cada grupo de quesitos, por intermédio de duas confrontações distintas: ( $($ ) resultados apurados nos dois Estudos de Caso com o referencial teórico da pesquisa, e (ii) resultados do Estudo de Caso 1 com os do Estudo de Caso 2.

\section{Resultados relacionados à interface entre o processo de Administração de Contrato e o de análise do risco}

A Tabela 5.2 apresenta os resultados dos Quesitos 7 e 8 da pesquisa, relativos aos fatores mais influentes no Gerenciamento de Projetos.

Os dados apurados mostram que, nos dois Estudos de Caso, os pontos de vista dos entrevistados são coincidentes no que se refere aos seguintes fatores e respectivas colocações obtidas:

- "Planejamento do projeto" (1 $\left.1^{\circ}\right)$,

- "Gestão do custo" ( $\left.8^{\circ}\right)$, 
- "Detalhamento da estimativa" $\left(10^{\circ}\right)$,

- "Produtividade da mão de obra de execução" (14º),

- "Memória técnica da execução" $\left(16^{\circ}\right)$.

Os 5 fatores citados representam 30,83\% do total da amostra do Estudo de Caso 1 e 30,20\% do Estudo de Caso 2.

A coincidência de respostas verificada na apuração da variável "Planejamento do projeto" - a indicação mais freqüente dos entrevistados - é importante ao principal objetivo deste trabalho, que é o de propor um conjunto mínimo de procedimentos que oriente o planejamento da Administração de Contrato.

Também vale ser destacada a coincidência de pontos de vista em 6 das 7 variáveis que perfazem $50 \%$ do total de indicações, com inversão das colocações. As variáveis e suas respectivas colocações no EC-1 e no EC-2 são as seguintes:

- "Planejamento do projeto" (1 $1^{\mathrm{a}}$ posição);

- “Organização do projeto” (2 e $5^{\mathrm{a}}$ posições);

- "Abrangência do escopo" ( $3^{\mathrm{a}}$ e $4^{\mathrm{a}}$ posições);

- “Designação das pessoas da equipe" (5 e $2^{a}$ posições);

- "Acompanhamento e avaliação progressiva" ( $6^{a}$ e $7^{a}$ posições); e

- "Avaliação estratégica da complexidade" (7a e $3^{a}$ posições). 
Tabela 5.2 - Fatores mais influentes no Gerenciamento de Projetos.

\begin{tabular}{|c|c|c|c|c|c|c|}
\hline \multicolumn{3}{|c|}{ Ponto de vista da Contratante (Estudo de Caso 1) } & \multirow{2}{*}{$\begin{array}{l}\text { Posição da } \\
\text { variável }\end{array}$} & \multicolumn{3}{|c|}{ Ponto de vista da Contratada (Estudo de Caso 2) } \\
\hline$\Sigma(\%)$ & $f(\%)$ & Variável & & Variável & $f(\%)$ & $\Sigma(\%)$ \\
\hline 8,10 & 8,10 & Planejamento do projeto & $1^{\circ}$ & Planejamento do projeto & 7,64 & 7,64 \\
\hline 15,76 & 7,67 & Organização do projeto & $2^{\circ}$ & Designação das pessoas da equipe & 7,31 & 14,94 \\
\hline 22,63 & 6,87 & Abrangência do escopo & $3^{\circ}$ & Avaliação estratégica da complexidade & 7,15 & 22,09 \\
\hline 29,38 & 6,75 & Estimativa do custo & $4^{\circ}$ & Abrangência do escopo & 7,12 & 29,21 \\
\hline 36,13 & 6,75 & Designação das pessoas da equipe & $5^{\circ}$ & Organização do projeto & 7,06 & 36,27 \\
\hline 42,80 & 6,67 & Acompanhamento e avaliação progressiva & $6^{\circ}$ & Caminho crítico da gestão & 6,62 & 42,89 \\
\hline 49,24 & 6,44 & Avaliação estratégica da complexidade & $7^{\circ}$ & Acompanhamento e avaliação progressiva & 6,54 & 49,43 \\
\hline 55,63 & 6,39 & Gestão do custo & $8^{\circ}$ & Gestão do custo & 6,50 & 55,93 \\
\hline 61,81 & 6,18 & Caminho crítico da gestão & $9^{\circ}$ & Estimativa do custo & 6,45 & 62,38 \\
\hline 67,91 & 6,10 & Detalhamento da estimativa & $10^{\circ}$ & Detalhamento da estimativa & 5,81 & 68,19 \\
\hline 73,65 & 5,74 & Produtividade da mão de obra de execução & $11^{\circ}$ & Produtividade da mão de obra de execução & 5,77 & 73,96 \\
\hline 79,39 & 5,74 & Software para gerenciamento do projeto & $12^{\circ}$ & Produtividade na operação de equipamento & 5,42 & 79,38 \\
\hline 85,03 & 5,64 & Finalização do projeto & $13^{\circ}$ & Aquisição de materiais de construção & 5,26 & 84,64 \\
\hline 90,29 & 5,26 & Produtividade na operação de equipamentos & $14^{\circ}$ & Finalização do projeto & 5,16 & 89,80 \\
\hline 95,20 & 4,91 & Aquisição de materiais de construção & $15^{\circ}$ & Software para gerenciamento do projeto & 5,09 & 94,89 \\
\hline 99,70 & 4,50 & Memória técnica da execução & $16^{\circ}$ & Memória técnica da execução & 4,48 & 99,37 \\
\hline 100,00 & 0,30 & Outros fatores & $17^{\circ}$ & Outros fatores & 0,63 & 100,00 \\
\hline
\end{tabular}

FONTE: Pesquisa do autor (Conforme as Tabelas C.10 a C.12 do APÊNDICE C, referentes aos Quesitos 7 e 8 do Questionário).

LEGENDA: $f=$ freqüência de resposta, em porcentagem. $\quad \Sigma=$ porcentagem acumulada. 


\section{Resultados relacionados à prática da Administração de Contrato}

As Tabelas 5.3 e 5.4 apresentam os resultados dos Quesitos 13 a 16 da pesquisa, relativos aos fatores mais influentes na Administração de Contrato (Quesitos 13 e 14) e aos fatores que afetam o atendimento de reivindicação contratual (Quesitos 15 e 16).

Quanto aos Quesitos 13 e 14, os dados denotam a coincidência de pontos de vista dos entrevistados, unicamente no que se refere ao fator "Domínio do escopo do contrato", primeiro colocado em ambos os Estudos de Caso. O fator citado representa 8,63\% do total da amostra do Estudo de Caso 1 e 8,32\% do Estudo de Caso 2, e é fundamental à proposição que representa o objetivo principal desta dissertação.

A diferença de prioridades dos dois ambientes pode ser aquilatada pela colocação obtida para o fator "Conhecimento sobre o cliente", posicionado em $2^{\circ}$ lugar no Estudo de Caso 2 e em $11^{\circ}$ lugar no Estudo de Caso 1. Convém assinalar que cliente, para a parte Contratante (EC-1), significa o operador aeroportuário, que tanto pode ser uma entidade externa à organização como uma dependência da própria organização. No que tange à parte Contratada (EC-2), o cliente é a Contratante, o que poderia explicar a importância atribuída ao fator.

Com referência aos resultados dos Quesitos 15 e 16 da pesquisa, os dados apurados mostram que, nos dois Estudos de Caso, os pontos de vista dos entrevistados são coincidentes no que se refere aos seguintes fatores e respectivas colocações obtidas:

- "Fundamentação técnica da reivindicação" $\left(1^{\circ}\right)$,

- "Fundamentação legal da reivindicação" (2 $\left.2^{\circ}\right)$,

- "Domínio do projeto pelo Gerente da obra" $\left(5^{\circ}\right)$,

- "Clareza no texto" $\left(7^{\circ}\right)$

- “Ambiente no canteiro de obra” $\left(12^{\circ}\right)$.

Os 5 fatores citados representam 41,93\% do total da amostra do Estudo de Caso 1 e 42,20\% do Estudo de Caso 2. É de se destacar, ainda, as colocações obtidas nos dois Casos para as variáveis colocadas nas 7 primeiras posições, que perfazem mais de 60\% do total de indicações, demonstrando a coincidência de prioridades dos ambientes pesquisados. As coincidências de pontos de vista verificadas nos Quesitos 13 a 16 são da máxima importância para a finalidade 
primeira desta dissertação. É preciso acentuar as diferentes ópticas dos entrevistados, nas respostas dadas aos Quesitos 15 e 16 do questionário:

- No Estudo de Caso 1, a pergunta é respondida pelo Gerente da parte Contratante, a quem a Contratada, ou um cliente da Contratante, apresentou uma reivindicação, e que tem o dever de manifestar-se a respeito, negando ou acolhendo na íntegra ou parcialmente a demanda apresentada, para assegurar a continuidade da execução do contrato;

- No Estudo de Caso 2, quem responde a pergunta é o Gerente da parte Contratada, o qual apresentou uma reivindicação à Contratante, esperando uma manifestação favorável sobre a demanda formulada, para reequilibrar a equação econômico-financeira do contrato.

\section{Resultados relacionados às habilidades técnicas e pessoais do Gerente}

Com referência aos Quesitos 9 a 12 do questionário, os entrevistados nos Estudos de Caso 1 e 2 afirmam que "Liderança" e "Pensamento crítico/ Tomada de decisão" constituem as principais habilidades que um Gerente de empresa privada ou do setor público deve ter, para reduzir os riscos e ter êxito no Gerenciamento de Projetos e, em conseqüência, na Administração de Contrato.

Além de concordarem quanto às habilidades referidas anteriormente, como indicado nas Tabelas 5.5 e 5.6, Contratante e Contratada também expressam idêntico ponto de vista no que diz respeito às seguintes habilidades e respectivas colocações:

- "Integração da equipe" (2a posição), “Avaliação do empreendimento como um todo" (3a posição) e "Desenvolvimento das pessoas" ( ${ }^{a}$ posição), conforme Tabela 5.6. As habilidades técnicas coincidentes representam 25,40\% do total da amostra do Estudo de Caso 1, e 25,35\% do Estudo de Caso 2; e

- "Negociação", "Flexibilidade" e "Comunicação escrita", conforme Tabela 5.7. As habilidades pessoais coincidentes representam 33,81\% do total da amostra do Estudo de Caso 1, e 33,33\% do Estudo de Caso 2.

Quanto ao fator "Necessidades do cliente", $4^{\circ}$ colocado do ponto de vista da Contratada (6,35\%) e $13^{\circ}$ colocado segundo a Contratante (5,19\%), vale a mesma observação feita anteriormente sobre o significado do termo "cliente". 
Tabela 5.3 - Fatores mais influentes na Administração de Contrato.

\begin{tabular}{|c|c|c|c|c|c|c|}
\hline \multicolumn{3}{|c|}{ Ponto de vista da Contratante (Estudo de Caso 1) } & \multirow{2}{*}{$\begin{array}{l}\text { Posição da } \\
\text { variável }\end{array}$} & \multicolumn{3}{|c|}{ Ponto de vista da Contratada (Estudo de Caso 2) } \\
\hline$\Sigma(\%)$ & $f(\%)$ & Variável & & Variável & $f(\%)$ & $\Sigma(\%)$ \\
\hline 8,63 & 8,63 & Domínio do escopo do contrato & $1^{\circ}$ & Domínio do escopo do contrato & 8,32 & 8,32 \\
\hline 16,64 & 8,01 & Compreensão da base técnica & $2^{\circ}$ & Conhecimento sobre o cliente & 8,04 & 16,36 \\
\hline 24,58 & 7,94 & Equipe qualificada & $3^{\circ}$ & Competência na negociação & 7,73 & 24,08 \\
\hline 32,38 & 7,79 & Compreensão da base legal & $4^{\circ}$ & Liderança & 7,55 & 31,64 \\
\hline 39,81 & 7,44 & Competência na negociação & $5^{\circ}$ & Equipe qualificada & 7,54 & 39,17 \\
\hline 47,16 & 7,35 & Apoio jurídico & $6^{\circ}$ & Compreensão da base legal & 7,37 & 46,54 \\
\hline 54,39 & 7,23 & Documentação e arquivo & $7^{\circ}$ & Compreensão da base técnica & 7,20 & 53,74 \\
\hline 61,61 & 7,22 & Coordenação de interfaces & $8^{\circ}$ & Registro de fatos & 7,01 & 60,75 \\
\hline 68,56 & 6,95 & Integração de atividades multifuncionais & $9^{\circ}$ & Orçamento como conseqüência do planejamento & 6,82 & 67,57 \\
\hline 75,51 & 6,95 & Liderança & $10^{\circ}$ & Coordenação de interfaces & 6,77 & 74,34 \\
\hline 82,37 & 6,86 & Conhecimento sobre o cliente & $11^{\circ}$ & Apoio jurídico & 6,76 & 81,10 \\
\hline 89,20 & 6,83 & Orçamento como conseqüência do planejamento & $12^{\circ}$ & Postura ganha-ganha & 6,31 & 87,41 \\
\hline 95,72 & 6,52 & Registro de fatos & $13^{\circ}$ & Documentação e arquivo & 6,30 & 93,71 \\
\hline 100,00 & 4,28 & Postura ganha-ganha & $14^{\circ}$ & Integração de atividades multifuncionais & 6,29 & 100,00 \\
\hline
\end{tabular}

FONTE: $\quad$ Pesquisa do autor (Conforme as Tabelas C.19 a C.21 do APÊNDICE C, referentes aos Quesitos 13 e 14 do Questionário).

LEGENDA: $f=$ freqüência de resposta, em porcentagem. $\quad \Sigma=$ porcentagem acumulada. 
Tabela 5.4 - Fatores que afetam o atendimento de reivindicação contratual.

\begin{tabular}{|c|c|c|c|c|c|c|}
\hline \multicolumn{3}{|c|}{ Ponto de vista da Contratante (Estudo de Caso 1) } & \multirow{2}{*}{$\begin{array}{l}\text { Posição da } \\
\text { variável }\end{array}$} & \multicolumn{3}{|c|}{ Ponto de vista da Contratada (Estudo de Caso 2) } \\
\hline$\Sigma(\%)$ & $f(\%)$ & Variável & & Variável & $f(\%)$ & $\Sigma(\%)$ \\
\hline 9,59 & 9,59 & Fundamentação legal da reivindicação & $1^{\circ}$ & Fundamentação técnica da reivindicação & 9,16 & 9,16 \\
\hline 19,18 & 9,59 & Fundamentação técnica da reivindicação & $2^{\circ}$ & Fundamentação legal da reivindicação & 9,05 & 18,21 \\
\hline 28,22 & 9,04 & Documentação de suporte & $3^{\circ}$ & Existência de registro dos fatos ocorridos & 9,02 & 27,23 \\
\hline 37,14 & 8,92 & Domínio do projeto pela equipe do Gerente da obra & $4^{\circ}$ & Documentação de suporte & 8,70 & 35,93 \\
\hline 45,99 & 8,85 & Domínio do projeto pelo Gerente da obra & $5^{\circ}$ & Domínio do projeto pelo Gerente da obra & 8,67 & 44,60 \\
\hline 54,57 & 8,59 & Existência de registro dos fatos ocorridos & $6^{\circ}$ & Domínio do projeto pela equipe do gerente da obra & 8,59 & 53,18 \\
\hline 62,90 & 8,33 & Clareza no texto & $7^{\circ}$ & Clareza no texto & 8,02 & 61,20 \\
\hline 70,99 & 8,10 & Pontualidade no cumprimento do cronograma físico & $8^{\circ}$ & Momento do projeto & 7,96 & 69,16 \\
\hline 79,02 & 8,03 & Procedimento de decisão da outra parte & $9^{\circ}$ & Qualidade na execução do projeto & 7,65 & 76,81 \\
\hline 87,03 & 8,01 & Qualidade na execução do projeto & $10^{\circ}$ & Procedimento de decisão da outra parte & 7,61 & 84,42 \\
\hline 94,16 & 7,13 & Momento do projeto & $11^{\circ}$ & Pontualidade no cumprimento do cronograma físico & 7,35 & 91,77 \\
\hline 99,73 & 5,57 & Ambiente no canteiro de obra & $12^{\circ}$ & Ambiente no canteiro de obra & 7,30 & 99,07 \\
\hline 100,00 & 0,27 & Outros fatores & $13^{\circ}$ & Outros fatores & 0,93 & 100,00 \\
\hline
\end{tabular}

FONTE: $\quad$ Pesquisa do autor (Conforme as Tabelas C.22 a C.24 do APÊNDICE C, referentes aos Quesitos 15 e 16 do Questionário).

LEGENDA: $\quad f=$ freqüência de resposta, em porcentagem. $\quad \Sigma$ = porcentagem acumulada.

OBSERVAÇÃO: $\quad$ No Estudo de Caso 1, a variável posicionada em $1^{\circ}$ lugar obteve 9,594\% das indicações, enquanto a classificada em $2^{\circ}$ lugar obteve 9,587\% (Ver Tabela C.24 do APÊNDICE C). 
Tabela 5.5 - Habilidades técnicas do Gerente, influentes na gestão de projetos.

\begin{tabular}{|c|c|c|c|c|c|c|}
\hline \multicolumn{3}{|c|}{ Ponto de vista da Contratante (Estudo de Caso 1) } & \multirow{2}{*}{$\begin{array}{l}\text { Posição da } \\
\text { variável }\end{array}$} & \multicolumn{3}{|c|}{ Ponto de vista da Contratada (Estudo de Caso 2) } \\
\hline$\Sigma(\%)$ & $f(\%)$ & Variável & & Variável & $f(\%)$ & $\Sigma(\%)$ \\
\hline 6,75 & 6,75 & Liderança & 10 & Liderança & 6,81 & 6,81 \\
\hline 13,27 & 6,52 & Integração da equipe & $2^{\circ}$ & Integração da equipe & 6,44 & 13,24 \\
\hline 19,55 & 6,28 & Avaliação do empreendimento como um todo & $3^{\circ}$ & Avaliação do empreendimento como um todo & 6,39 & 19,64 \\
\hline 25,73 & 6,18 & Delegação & $4^{\circ}$ & Necessidades do cliente & 6,35 & 25,99 \\
\hline 31,89 & 6,16 & Desempenho (método de trabalho) do gerente & $5^{\circ}$ & Estratégia & 6,29 & 32,28 \\
\hline 37,96 & 6,07 & Estratégia & $6^{\circ}$ & Delegação & 6,14 & 38,42 \\
\hline 43,91 & 5,95 & Administração simultânea de múltiplas prioridades & $7^{\circ}$ & Conhecimento das próprias forças e fraquezas & 5,81 & 44,23 \\
\hline 49,76 & 5,85 & Desenvolvimento das pessoas & $8^{\circ}$ & Desenvolvimento das pessoas & 5,71 & 49,93 \\
\hline 55,36 & 5,61 & Conhecimento das próprias forças e fraquezas & $9^{\circ}$ & Seleção e mobilização da equipe & 5,70 & 55,63 \\
\hline 60,78 & 5,42 & Seleção e mobilização da equipe & $10^{\circ}$ & Visão da oportunidade & 5,56 & 61,19 \\
\hline 66,16 & 5,38 & Conceito das funções do processo de gestão & $11^{\circ}$ & Administração simultânea de múltiplas prioridades & 5,51 & 66,70 \\
\hline 71,50 & 5,34 & Ajuste do estilo de liderança ao longo da execução & $12^{\circ}$ & Conceito das funções do processo de gestão & 5,20 & 71,90 \\
\hline 76,70 & 5,19 & Necessidades do cliente & $13^{\circ}$ & Desempenho (método de trabalho) do gerente & 5,16 & 77,06 \\
\hline 81,69 & 4,99 & Visão da oportunidade & $14^{\circ}$ & Ajuste do estilo de liderança ao longo da execução & 5,14 & 82,20 \\
\hline 86,43 & 4,74 & Reuniões periódicas & $15^{\circ}$ & Tática & 4,79 & 86,99 \\
\hline 91,04 & 4,61 & Tática & $16^{\circ}$ & Procedimentos e políticas & 4,64 & 91,62 \\
\hline 95,62 & 4,58 & Procedimentos e políticas & $17^{\circ}$ & Escolha da melhor maneira de orçar & 4,42 & 96,05 \\
\hline 100,00 & 4,38 & Escolha da melhor maneira de orçar & $18^{\circ}$ & Reuniões periódicas & 3,95 & 100,00 \\
\hline
\end{tabular}

FONTE: $\quad$ Pesquisa do autor (Conforme as Tabelas C.13 a C.15 do APÊNDICE C, referentes aos Quesitos 9 e 10 do Questionário).

LEGENDA: $f=$ freqüência de resposta, em porcentagem. $\quad \Sigma=$ porcentagem acumulada. 
Tabela 5.6 - Habilidades pessoais do Gerente, influentes na gestão de projetos.

\begin{tabular}{|c|c|c|c|c|c|c|}
\hline \multicolumn{3}{|c|}{ Ponto de vista da Contratante (Estudo de Caso 1) } & \multirow{2}{*}{$\begin{array}{c}\text { Posição da } \\
\text { variável }\end{array}$} & \multicolumn{3}{|c|}{ Ponto de vista da Contratada (Estudo de Caso 2) } \\
\hline$\Sigma(\%)$ & $f(\%)$ & Variável & & Variável & $f(\%)$ & $\Sigma(\%)$ \\
\hline 9,33 & 9,33 & Pensamento crítico/ Tomada de decisão & $1^{\circ}$ & Pensamento crítico/ Tomada de decisão & 9,05 & 9,05 \\
\hline 18,52 & 9,19 & Objetividade e clareza em apresentar/ oferecer & $2^{\circ}$ & Estimulador/ Educador de pessoas & 9,02 & 18,07 \\
\hline 27,14 & 8,63 & Negociação & $3^{\circ}$ & Negociação & 8,82 & 26,89 \\
\hline 35,75 & 8,61 & Solução de conflitos & $4^{\circ}$ & Objetividade e clareza em apresentar/ oferecer & 8,75 & 35,64 \\
\hline 44,20 & 8,45 & Comunicação verbal & $5^{\circ}$ & Criatividade & 8,69 & 44,32 \\
\hline 52,51 & 8,31 & Criatividade & $6^{\circ}$ & Influenciador & 8,67 & 53,00 \\
\hline 60,71 & 8,20 & Flexibilidade & $7^{\circ}$ & Flexibilidade & 8,49 & 61,49 \\
\hline 68,80 & 8,09 & Sociabilidade & $8^{\circ}$ & Comunicação verbal & 8,17 & 69,66 \\
\hline 76,84 & 8,03 & Estimulador/ Educador de pessoas & $9^{\circ}$ & Solução de conflitos & 8,12 & 77,78 \\
\hline 84,80 & 7,97 & Solução de problemas técnicos & $10^{\circ}$ & Sociabilidade & 7,51 & 85,29 \\
\hline 92,46 & 7,65 & Comunicação escrita & $11^{\circ}$ & Comunicação escrita & 6,97 & 92,26 \\
\hline 99,61 & 7,16 & Influenciador & $12^{\circ}$ & Solução de problemas técnicos & 6,86 & 99,13 \\
\hline 100,00 & 0,39 & Outras habilidades & $13^{\circ}$ & Outras habilidades & 0,87 & 100,00 \\
\hline
\end{tabular}

FONTE: $\quad$ Pesquisa do autor (Conforme as Tabelas C.16 a C.18 do APÊNDICE C, referentes aos Quesitos 11 e 12 do Questionário).

LEGENDA: $f=$ freqüência de resposta, em porcentagem. $\quad \Sigma=$ porcentagem acumulada. 


\section{Considerações finais sobre os resultados apurados}

Os resultados obtidos na apuração das respostas aos Quesitos 7 a 16 do questionário atendem o objetivo específico dos levantamentos de campo realizados, expresso no Capítulo 1 deste trabalho e confirmam, no seu conjunto, as técnicas e habilidades integrantes do referencial teórico da pesquisa, constante dos Capítulos 3 e 4. Isto indica que este referencial teórico, no âmbito dos Estudos de Caso, se mostra adequado às necessidades de uma Administração de Contratos orientada ao gerenciamento integrado e com foco na gestão de riscos.

De fato, em cada Quesito foi dada aos entrevistados a opção de resposta "Outros", que lhes possibilitava a indicação de novos fatores, habilidades e requisitos, distintos daqueles originalmente constantes do questionário distribuído. Constatou-se que a freqüência de indicações dos entrevistados à opção "Outros”, nos Quesitos em que essa opção foi utilizada, não alcançou a marca de 1\% das respostas dadas, sendo que nos Quesitos 9, 10, 13 e 14 a assinalação foi nula, conforme mostra a Tabela 5.7.

Tabela 5.7 - Freqüência de respostas à opção "Outros".

\begin{tabular}{c|c|c}
\hline $\begin{array}{c}\text { Estudo de } \\
\text { Caso } 1\end{array}$ & Quesitos do questionário & $\begin{array}{c}\text { Estudo de } \\
\text { Caso } 2\end{array}$ \\
\hline $0,30 \%$ & (7 e 8) Fatores que mais influem no Gerenciamento de Projetos & $0,63 \%$ \\
0 & (9 e 10) Habilidades técnicas do gerente, que mais influem no Gerenciamento de Projetos & 0 \\
$0,39 \%$ & $(11$ e 12) Habilidades pessoais do gerente, que mais influem no Gerenciamento de Projetos & $0,87 \%$ \\
0 & (13 e 14) Requisitos que mais influem na prática da Administração de Contrato & 0 \\
$0,27 \%$ & (15 e 16) Fatores que afetam o atendimento de reivindicação contratual & $0,93 \%$ \\
\hline
\end{tabular}

FONTE: Pesquisa do autor.

Uma segunda confrontação, cotejando os resultados do Estudo de Caso 1 com os do Estudo de Caso 2, não revelou a existência de divergências significativas, como demonstram os dados constantes das tabelas apresentadas no item 5.4 deste Capítulo, sendo possivelmente explicáveis pelas diferentes formas de gestão corporativa de cada organização onde a pesquisa teve lugar, e também pelo desempenho dos seus respectivos papéis, uma na qualidade de entidade que promove licitações visando contratar Projetos e a outra, que os executa. 
A Tabela 5.8 proporciona um panorama dos pontos de vista das partes Contratante e Contratada pesquisadas, apresentando, para cada Quesito do questionário, a resposta que ocorreu com a maior freqüência ("moda") e o seu respectivo valor na relação. A destacar, nessa Tabela, a convergência dos pontos de vista das partes contratante e contratada, verificada em todas as modas dos Quesitos 7 a 14, e praticamente também nas modas dos Quesitos 15 e 16, nos quais as variáveis colocadas em primeiro e segundo lugares acham-se tecnicamente empatadas, como mostra a Tabela 5.5.

Como reflexão final dos resultados observados nestes estudos de caso, pode-se concluir que os referenciais teóricos construídos para a prática da Administração de Contratos, bem como os aspectos de interfaces com os processos de Gestão de Riscos, podem ser considerados adequados e válidos. Vale dizer que, conforme a metodologia preconizada por Yin, é admissível que a aplicação destas práticas na Administração de Contratos possa ser estendida para outros empreendimentos de natureza semelhante. 
Tabela 5.8 - Respostas mais freqüentes de cada Quesito do questionário.

\begin{tabular}{|c|c|c|c|c|}
\hline \multicolumn{2}{|r|}{ Ponto de vista da Contratante (EC-1) } & \multirow{2}{*}{$\begin{array}{c}\text { Quesitos } \\
\text { (1) Formação profissional }\end{array}$} & \multicolumn{2}{|l|}{ Ponto de vista da Contratada (EC-2) } \\
\hline $69 \%$ & Engenheiro (a) & & Engenheiro (a) & $85 \%$ \\
\hline $39 \%$ & 21 anos ou mais & (2) Experiência profissional & 21 anos ou mais & $46 \%$ \\
\hline $26 \%$ & De 6 a 10 anos & (3) Lotação em canteiros de obras & 15 anos ou mais & $39 \%$ \\
\hline $38 \%$ & Empreitada por preço unitário e global & (4) Regime de execução de contrato & Empreitada por preço unitário & $30 \%$ \\
\hline $66 \%$ & Somente 1 regime & (4) Experiência com múltiplos regimes de execução & Somente 1 regime & $33 \%$ \\
\hline $27 \%$ & De 6 a 10 anos & (5) Experiência em Administração de Contrato & De 6 a 10 anos & $20 \%$ \\
\hline $22 \%$ & Com base no planejamento & (6) Principal meio de aprendizagem em Administração de Contrato & Com base no planejamento & $19 \%$ \\
\hline $8 \%$ & Planejamento do projeto & (7) e (8) Fator que mais influi no Gerenciamento de Projetos & Planejamento do projeto & $8 \%$ \\
\hline $7 \%$ & Liderança & (9 e 10) Habilidade técnica do Gerente, mais influente no Gerenciamento de Projetos & Liderança & $7 \%$ \\
\hline $9 \%$ & Pensamento crítico/ Tomada de decisão & (11 e 12) Habilidade pessoal mais influente no Gerenciamento de Projetos & Pensamento crítico/ Tomada de decisão & $9 \%$ \\
\hline $9 \%$ & Domínio do escopo do contrato & (13 e 14) Requisito que mais influi na prática da Administração de Contrato & Domínio do escopo do contrato & $8 \%$ \\
\hline $10 \%$ & Fundamentação legal da reivindicação & (15 e 16) Fator que mais afeta o atendimento de reivindicação contratual & Fundamentação técnica da reivindicação & $9 \%$ \\
\hline
\end{tabular}

FONTE: $\quad$ Pesquisa do autor.

OBSERVAÇÃO: Nesta Tabela a apresentação dos resultados é feita em percentuais inteiros, com arredondamento das casas decimais. 


\section{REQUISITOS DO PLANEJAMENTO DA ADMINISTRAÇÃO DE CONTRATO}

Um bom começo já é a metade da operação.

(Platão)

No Capítulo 4 desta dissertação, foi visto que o plano de resposta aos riscos do Projeto, concebido na fase de proposta, constitui o registro da estratégia e das táticas a serem empregadas na execução do empreendimento, na hipótese que o contrato seja assinado pelas partes compradora e vendedora.

De um ponto de vista da parte compradora, em projetos de construção pesada o risco é tomado no momento da divulgação do edital da licitação, ou do convite para oferecimento de proposta, dirigido a um ou mais possíveis interessados. A minuta do contrato e as diretrizes contidas no edital ou no convite, revelam os parâmetros que o comprador utilizará para administrar o futuro contrato.

Em se tratando da parte vendedora, é a apresentação da proposta que assinala o momento da efetiva aceitação do risco. Assim, o planejamento da Administração de Contrato surge durante a elaboração da proposta do vendedor, como conseqüência do plano de resposta aos riscos, que passa a ser detalhado em nível operacional logo após a assinatura do contrato entre as partes Contratante e Contratada.

A assinatura do contrato marca o início da Administração de Contrato. O plano existente antes da assinatura pode agora dar lugar a um programa, cujo êxito demanda esforço coletivo e que depende, essencialmente, de domínio do escopo do contrato pelos integrantes da equipe de gerenciamento e também da capacidade da equipe, de conduzir e monitorar o andamento do programa.

As gestões contemporâneas de projetos e de contratos exigem que o gerente detenha um conjunto de habilidades, facilitando e calibrando a tomada de decisões técnicas e empresariais, segundo Kerzner (2006a). Wysocki e Lewis (2000); Dinsmore e Silveira Neto (2005); McManus, 
Jentzen e Greenberg (1996), além de alguns levantamentos realizados pelo autor anteriormente aos da pesquisa objeto desta dissertação, permitem o agrupamento dos fatores e habilidades que mais influem nas práticas do Gerenciamento de Projetos e da Administração de Contrato, como mostram os conjuntos indicados nos Quadros 6.1 a 6.5 .

Abrangência do escopo
Acompanhamento e avaliação progressiva
Aquisição de materiais de construção
Avaliação estratégica da complexidade
Caminho crítico da gestão
Memória técnica da execução
Designação das pessoas da equipe
Detalhamento da estimativa
Estimativa do custo
Finalização do projeto
Gestão do custo
Organização do projeto
Planejamento do projeto
Produtividade da mão de obra de execução
Produtividade na operação de equipamentos
Software para gerenciamento do projeto

FONTE: Elaborado pelo autor, a partir de Wysocki \& Lewis (2000) e Dinsmore e Silveira Neto (2005).

Quadro 6.1 - Fatores críticos à gestão de projetos.

\author{
Administração simultânea de múltiplas prioridades \\ Ajuste do estilo de liderança ao longo da execução \\ Avaliação do empreendimento como um todo \\ Conceito das funções do processo de gestão \\ Conhecimento das próprias forças e fraquezas \\ Delegação \\ Desempenho (método de trabalho) do gerente \\ Desenvolvimento das pessoas \\ Escolha da melhor maneira de orçar \\ Estratégia \\ Integração da equipe \\ Liderança \\ Necessidades do Cliente \\ Procedimentos e políticas
}

(Continua) 
(Conclusão)

$$
\begin{aligned}
& \text { Reuniões periódicas } \\
& \text { Seleção e mobilização da equipe } \\
& \text { Tática } \\
& \text { Visão da oportunidade }
\end{aligned}
$$

FONTE: Elaborado pelo autor, a partir de Wysocki \& Lewis (2000) e Dinsmore e Silveira Neto (2005).

Quadro 6.2 - Habilidades técnicas críticas à gestão de projetos.

Comunicação escrita
Comunicação verbal
Criatividade
Estimulador/ Educador de pessoas
Flexibilidade
Influenciador
Negociação
Objetividade e clareza em apresentar/oferecer
Pensamento crítico/ Tomada de decisão
Sociabilidade
Solução de conflitos
Solução de problemas técnicos

FONTE: Elaborado pelo autor, a partir de Wysocki \& Lewis (2000) e Dinsmore e Silveira Neto (2005).

Quadro 6.3 - Habilidades pessoais críticas à gestão de projetos.

Apoio jurídico
Competência na negociação
Compreensão da base legal
Compreensão da base técnica
Conhecimento sobre o Cliente
Coordenação de interfaces
Documentação e arquivo
Domínio do escopo do contrato
Equipe qualificada
Integração de atividades multifuncionais
Liderança
Orçamento como conseqüência do planejamento
Postura ganha-ganha
Registro de fatos

FONTE: Elaborado pelo autor, a partir de Dinsmore e Silveira Neto (2005).

Quadro 6.4 - Requisitos críticos à Administração de Contrato. 


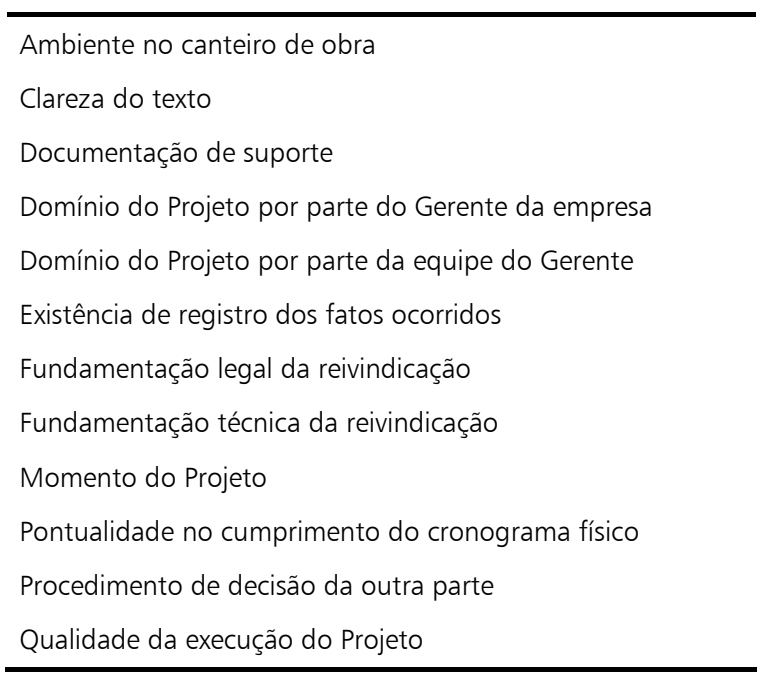

FONTE: Elaborado pelo autor, a partir de McManus, Jentzen, Greenberg (1996) e de outros levantamentos realizados pelo autor, anteriormente aos desta pesquisa.

Quadro 6.5 - Requisitos críticos ao atendimento de reivindicação contratual.

Os autores citados nos Quadros até aqui apresentados neste Capítulo não estabelecem uma hierarquia para as técnicas e habilidades por eles apontadas. A investigação relatada no Capítulo 5, realizada junto a duas importantes organizações da construção pesada brasileira, uma atuando na qualidade de contratante de projetos e a outra, na de executora, proporcionou uma hierarquização para estas mesmas técnicas e habilidades. As Tabelas 6.1 a 6.4 mostram os resultados alcançados relativos aos requisitos mais influentes à prática da Administração de Contrato, bem como os fatores que influenciam o atendimento de reivindicação contratual apresentada pelo fornecedor ao comprador.

Tabela 6.1 - Requisitos mais influentes na prática da Administração de Contrato Ponto de vista da parte Contratante.

\begin{tabular}{|c|c|c|c|}
\hline Posição & Requisito & Freqüência (\%) & $\begin{array}{c}\text { Freqüência } \\
\text { acumulada (\%) }\end{array}$ \\
\hline $1^{\circ}$ & Domínio do escopo do contrato & 8,63 & 8,63 \\
\hline $2^{\circ}$ & Compreensão da base técnica & 8,01 & 16,64 \\
\hline $3^{\circ}$ & Equipe qualificada & 7,94 & 24,58 \\
\hline $4^{\circ}$ & Compreensão da base legal & 7,79 & 32,38 \\
\hline $5^{\circ}$ & Competência na negociação & 7,44 & 39,81 \\
\hline
\end{tabular}


(Conclusão)

\begin{tabular}{|c|c|c|c|}
\hline Posição & Requisito & Freqüência (\%) & $\begin{array}{c}\text { Freqüência } \\
\text { acumulada (\%) }\end{array}$ \\
\hline $6^{\circ}$ & Apoio jurídico & 7,35 & 47,16 \\
\hline $7^{\circ}$ & Documentação e arquivo & 7,23 & 54,39 \\
\hline $8^{\circ}$ & Coordenação de interfaces & 7,22 & 61,61 \\
\hline $9^{\circ}$ & Integração de atividades multifuncionais & 6,95 & 68,56 \\
\hline $10^{\circ}$ & Liderança & 6,95 & 75,51 \\
\hline $11^{\circ}$ & Conhecimento sobre o Cliente & 6,86 & 82,37 \\
\hline $12^{\circ}$ & Orçamento como conseqüência do planejamento & 6,83 & 89,20 \\
\hline $13^{\circ}$ & Registro de fatos & 6,52 & 95,72 \\
\hline $14^{\circ}$ & Postura ganha-ganha & 4,28 & 100,00 \\
\hline
\end{tabular}

FONTE: Pesquisa do autor.

Tabela 6.2 - Requisitos mais influentes na prática da Administração de Contrato Ponto de vista da parte Contratada.

\begin{tabular}{|c|c|c|c|}
\hline Posição & Requisito & Freqüência (\%) & $\begin{array}{c}\text { Freqüência } \\
\text { acumulada (\%) }\end{array}$ \\
\hline $1^{\circ}$ & Domínio do escopo do contrato & 8,32 & 8,32 \\
\hline $2^{\circ}$ & Conhecimento sobre o Cliente & 8,04 & 16,36 \\
\hline $3^{\circ}$ & Competência na negociação & 7,73 & 24,08 \\
\hline $4^{\circ}$ & Liderança & 7,55 & 31,64 \\
\hline $5^{\circ}$ & Equipe qualificada & 7,54 & 39,17 \\
\hline $6^{\circ}$ & Compreensão da base legal & 7,37 & 46,54 \\
\hline $7^{\circ}$ & Compreensão da base técnica & 7,20 & 53,74 \\
\hline $8^{\circ}$ & Registro de fatos & 7,01 & 60,75 \\
\hline $9^{\circ}$ & Orçamento como conseqüência do planejamento & 6,82 & 67,57 \\
\hline $10^{\circ}$ & Coordenação de interfaces & 6,77 & 74,34 \\
\hline $11^{\circ}$ & Apoio jurídico & 6,76 & 81,10 \\
\hline $12^{\circ}$ & Postura ganha-ganha & 6,31 & 87,41 \\
\hline $13^{\circ}$ & Documentação e arquivo & 6,30 & 93,71 \\
\hline $14^{\circ}$ & Integração de atividades multifuncionais & 6,29 & 100,00 \\
\hline
\end{tabular}

FONTE: Pesquisa do autor. 
Tabela 6.3 - Fatores que afetam o atendimento de reivindicação contratual Ponto de vista da parte Contratante.

\begin{tabular}{|c|c|c|c|}
\hline Posição & Fator & Freqüência (\%) & $\begin{array}{c}\text { Freqüência } \\
\text { acumulada (\%) }\end{array}$ \\
\hline $1^{\circ}$ & Fundamentação legal da reivindicação & 9,59 & 9,59 \\
\hline $2^{\circ}$ & Fundamentação técnica da reivindicação & 9,59 & 19,18 \\
\hline $3^{\circ}$ & Documentação de suporte & 9,04 & 28,22 \\
\hline $4^{\circ}$ & Domínio do projeto pela equipe do gerente da obra & 8,92 & 37,14 \\
\hline $5^{\circ}$ & Domínio do projeto pelo gerente da obra & 8,85 & 45,99 \\
\hline $6^{\circ}$ & Existência de registro dos fatos ocorridos & 8,59 & 54,57 \\
\hline $7^{\circ}$ & Clareza no texto & 8,33 & 62,90 \\
\hline $8^{\circ}$ & Pontualidade no cumprimento do cronograma físico & 8,10 & 70,99 \\
\hline $9^{\circ}$ & Procedimento de decisão & 8,03 & 79,02 \\
\hline $10^{\circ}$ & Qualidade da execução do projeto & 8,01 & 87,03 \\
\hline $11^{\circ}$ & Momento do projeto & 7,13 & 94,16 \\
\hline $12^{\circ}$ & Ambiente no canteiro de obra & 5,57 & 99,73 \\
\hline $13^{\circ}$ & Outros fatores & 0,27 & 100,00 \\
\hline
\end{tabular}

FONTE: Pesquisa do autor.

Tabela 6.4 - Fatores que afetam o atendimento de reivindicação contratual Ponto de vista da parte Contratada.

\begin{tabular}{cccc}
\hline Posição & Fator & Freqüência (\%) & $\begin{array}{c}\text { Freqüência } \\
\text { acumulada (\%) }\end{array}$ \\
\hline $1^{\circ}$ & Fundamentação técnica da reivindicação & 9,16 & 9,16 \\
$2^{\circ}$ & Fundamentação legal da reivindicação & 9,05 & 18,21 \\
$3^{\circ}$ & Existência de registro dos fatos ocorridos & 9,02 & 35,93 \\
$4^{\circ}$ & Documentação de suporte & 8,70 & 44,60 \\
$5^{\circ}$ & Domínio do projeto pelo gerente da obra & 8,67 & 53,18 \\
$6^{\circ}$ & Domínio do projeto pela equipe do gerente da obra & 8,59 & 61,20 \\
$7^{\circ}$ & Clareza no texto & 8,02 & 69,16 \\
$8^{\circ}$ & Momento do projeto & 7,96 & 76,81
\end{tabular}


(Conclusão)

\begin{tabular}{|c|c|c|c|}
\hline Posição & Fator & Freqüência (\%) & $\begin{array}{c}\text { Freqüência } \\
\text { acumulada (\%) }\end{array}$ \\
\hline $9^{\circ}$ & Qualidade da execução do projeto & 7,65 & 76,81 \\
\hline $10^{\circ}$ & Procedimento de decisão & 7,61 & 84,42 \\
\hline $11^{\circ}$ & Pontualidade no cumprimento do cronograma físico & 7,35 & 91,77 \\
\hline $12^{\circ}$ & Ambiente no canteiro de obra & 7,30 & 99,07 \\
\hline $13^{\circ}$ & Outros fatores & 0,93 & 100,00 \\
\hline
\end{tabular}

FONTE: Pesquisa do autor.

Para coordenar o esforço coletivo demandado pelo processo da Administração de Contrato, bem como integrar as diversas atividades que o compõem, convém que o Gerente designe um responsável pela condução do referido processo, com o seguinte conjunto básico de atribuições:

- Consolidar o plano estratégico do Projeto e definir o processo de comunicação interna entre as empresas envolvidas;

- Estabelecer critérios para realizar o controle financeiro do Projeto. Coordenar e integrar os acompanhamentos físico e financeiro do Projeto;

- Elaborar o regulamento e rotinas operacionais do consórcio, em complementação aos Termos Legais que venham a ser estabelecidos;

- Definir e implantar o processo de comunicação entre as partes Contratante e Contratada, incluindo recepção e expedição de documentos, e o plano de reuniões periódicas;

- Definir e implantar processos de gestão de informações e de colaboração entre os principais interessados no contrato;

- Estabelecer a política de contratação de fornecedores de bens e prestadores de serviços, e as rotinas de convite, licitação, contratação, acompanhamento e avaliação de desempenho;

- Acompanhar as programações executivas e analisar os resultados dos desempenhos. Analisar e aprovar as programações executivas dos subcontratados;

- Estabelecer um programa de capacitação em Administração de Contrato e aplicá-lo a todos os integrantes da equipe de gerenciamento, com os objetivos de: (i) proporcionarlhes o domínio do escopo do contrato e (ii) torná-los educadores das suas respectivas equipes de campo. 
Considerando as atribuições descritas anteriormente, a primeira providência do responsável pelo processo de administração contratual, no sentido de planejá-lo, necessariamente deve consistir da análise (ou re-análise) crítica do instrumento do contrato celebrado entre as partes, incluindo os documentos que o integram sob a forma de anexos, ou nele simplesmente citados, dos quais se destacam:

- Instruções normativas, resoluções, portarias, regulamentos, decretos e leis, municipais, estaduais e federais;

- Normas técnicas, memoriais descritivos, especificações técnicas e desenhos componentes do projeto básico ou executivo;

- Propostas técnica e comercial apresentadas pela Contratada, com especial atenção para as qualificações e condicionamentos nelas constantes;

- Edital de licitação, ou conjunto de diretrizes fornecidas pela Contratante, em se tratando de convite, e esclarecimentos adicionais por ela prestados durante a licitação.

Dada a natureza jurídica da matéria em exame, é importante que haja participação de advogado nessa análise, entre outras razões para assegurar que: (i) sejam feitos esclarecimentos e distinções conceituais de natureza jurídica, por pessoa habilitada para tanto; (ii) sejam observados os preceitos de interpretação indicados no Capítulo 3 desta dissertação; (iii) sejam corretamente identificados eventos que poderão ensejar a revisão do preço do contrato; e (iv) sejam identificadas as cláusulas contratuais influentes no cálculo de danos, tais como aquelas apresentadas nos Quadros 6.6 e 6.7.

\begin{tabular}{|c|c|}
\hline Cláusulas favoráveis à Contratante & Cláusulas desfavoráveis à Contratante \\
\hline Cláusulas de indenização & $\begin{array}{l}\text { Cláusulas de indenização limitadas, qualificadas ou } \\
\text { condicionadas }\end{array}$ \\
\hline $\begin{array}{l}\text { Decisão da empresa responsável pelo projeto básico, } \\
\text { como final e vinculatória }\end{array}$ & \multirow{2}{*}{$\begin{array}{l}\text { Cláusulas de decisão limitada da empresa responsável } \\
\text { pelo projeto básico }\end{array}$} \\
\hline Cláusulas detalhadas de trabalho extraordinário, e de & \\
\hline trabalhos extraordinários de pequena monta & \multirow{2}{*}{$\begin{array}{l}\text { Cláusulas de trabalhos extraordinários em aberto, ou } \\
\text { vagas }\end{array}$} \\
\hline Cláusulas detalhadas sobre alterações & \\
\hline $\begin{array}{l}\text { Cláusulas de nenhum ressarcimento de danos por } \\
\text { atraso, rompimento, impedimento ou interferências }\end{array}$ & $\begin{array}{l}\text { Cláusulas que permitam reivindicações por atraso ou } \\
\text { ressarcimento de danos por atraso }\end{array}$ \\
\hline $\begin{array}{l}\text { Cláusulas de pagamento exigindo liberação de bens e } \\
\text { reivindicações }\end{array}$ & $\begin{array}{l}\text { Cláusulas de rescisão que permitam a recuperação de } \\
\text { custos indiretos e lucros sobre trabalho não realizado }\end{array}$ \\
\hline $\begin{array}{l}\text { Rescisão do contrato por cláusulas de conveniência, } \\
\text { limitando a exposição a reivindicações }\end{array}$ & \multirow[t]{2}{*}{$\begin{array}{l}\text { Tentativas de condicionar, qualificar ou limitar } \\
\text { ressarcimentos por danos liquidados }\end{array}$} \\
\hline Cláusulas de danos liquidados por conclusão em atraso & \\
\hline
\end{tabular}

FONTE: Schwartzkopf e McNamara (2001, p. 303, tradução do autor).

Quadro 6.6 - Cláusulas contratuais que afetam cálculos de danos, do ponto de vista da Contratante. 
Cláusulas favoráveis à Contratada

Indenização limitada apenas para negligência da Contratada.

Cláusulas de condições ocultas que permitam ajuste eqüitativo ao preço e prazo do contrato

Cláusulas por trabalho extraordinário realizado mediante notificação razoável à Contratante

Cláusulas que permitam recuperação de ressarcimentos por danos relacionados a atrasos

Cláusulas que permitam a recuperação de custos indiretos, sobre-custos e lucro, na eventualidade de rescisão
Cláusulas desfavoráveis à Contratada

Cláusulas que tornam o pagamento dependente de qualquer outro evento, exceto a execução do trabalho

Decisão da empresa responsável pelo projeto básico como sendo final e vinculatória

Cláusulas detalhadas e complexas para trabalho extraordinário

Nenhum ressarcimento de danos por cláusulas de atraso

Cláusulas de danos liquidados

Cláusulas sobre disposição de notificação detalhada

Arbitragem à escolha da Contratada

FONTE: Schwartzkopf e McNamara (2001, p. 303, tradução do autor).

Quadro 6.7 - Cláusulas contratuais que afetam cálculos de danos, do ponto de vista da Contratada.

A seguir, tomando por base a análise que foi feita do contrato e dos documentos a ele anexados, o responsável pela Administração do Contrato deve elaborar um sumário executivo desse conjunto de documentos (geralmente volumoso em se tratando de obras de construção pesada), e divulgálo aos integrantes da equipe de gerenciamento do Projeto, permitindo assim a consulta rápida, tempestiva e freqüente do contrato no dia-a-dia de execução da obra, além de facilitar a sua compreensão.

O sumário executivo deve apresentar, de maneira clara e objetiva, dentre outras informações:

- Relação de todo o conteúdo contratual;

- Relação de todas as cláusulas contratuais;

- Articulação dos documentos contratuais, na ordem de precedência expressa no contrato;

- Articulação das cláusulas integrantes do contrato, por assuntos afins;

- Fluxogramas dos vários procedimentos estabelecidos no contrato;

- Diagramas dos prazos de cumprimento das obrigações, especialmente o relativo ao processo de medição e pagamento de serviços executados;

- Extratos do contrato, especialmente das cláusulas "Objeto", "Obrigações das partes" e "Medição e pagamento";

- Formulários a serem observados por força das disposições contratuais. 
Tendo sido feita a análise crítica do contrato e elaborado o seu sumário executivo, podem então ser providenciados e implantados os critérios, rotinas e procedimentos a cargo do responsável pela administração contratual, indicados neste Capítulo.

O planejamento da Administração de Contrato consolida-se com a prestação de esclarecimentos à equipe de gerenciamento do Projeto, a respeito dos propósitos da administração contratual e dos principais aspectos do contrato assinado, especialmente as obrigações e responsabilidades assumidas pelas partes em decorrência dessa assinatura.

Concluído o planejamento, deve-se implantar um programa de aprimoramento contínuo do processo de administração contratual, visando mantê-lo robusto e atualizado.

A estrutura recomendada neste Capítulo para planejamento da Administração de Contrato, contempla os requisitos de gerenciamento preconizados na doutrina e confirmados nos dois levantamentos de campo realizados. A principal contribuição que se espera desse conjunto mínimo de procedimentos, é facilitar o deslinde de disputas contratuais, quase que inevitáveis no segmento estudado, com o que poderá ser evitada a descontinuidade da execução de empreendimentos de infra-estrutura. Isto poderá potencializar a relação entre as partes Contratante e Contratada e ensejar novas oportunidades de negócio.

Tal estrutura de referência deve sofrer ajuste em cada caso concreto de aplicação, levando em conta as características específicas de cada Projeto, as disposições do instrumento de contrato e o nível de maturidade da equipe de gerenciamento.

Destaca-se que a aplicação do processo sugerido requer a mobilização de equipe com qualificação específica nos processos de gerenciamento de riscos e de aquisições do Projeto, desde a fase de licitação do empreendimento, e também requer do Gerente disposição para delegar responsabilidades e trabalhar em equipe..

Finalmente, deve-se reconhecer que a aplicação deste referencial não garante a qualidade da execução do Projeto, nem tampouco a solução de disputas que vierem a ocorrer. 


\section{CONSIDERAÇÕES FINAIS}

Ao longo do desenvolvimento deste trabalho, buscou-se exprimir a importância da Administração de Contrato no âmbito das obras do setor da construção civil pesada no Brasil, traçando um quadro referencial e recomendando um conjunto mínimo de procedimentos, delineado sob um ponto de vista do gerenciamento de riscos, que oriente o planejamento daquele processo.

A abordagem teve início com a realização de pesquisa bibliográfica, visando estabelecer os elementos de subordinação do processo de Administração de Contrato ao de gerenciamento de riscos, por meio da distinção e análise das suas características, funções e interfaces, bem como dos fatores e habilidades de gestão que influem nesses processos. Procurou-se discutir o contrato, em razão de ser esse o eixo de desenvolvimento dos processos de gestão de riscos e de contratos.

À pesquisa bibliográfica seguiu-se a realização de dois Estudos de Caso, com o intuito de conduzir uma reflexão a respeito do conjunto referencial de fatores e habilidades desenhado na etapa anterior do trabalho, tudo considerado sob duas ópticas: uma da parte que contrata Projetos e a outra da parte que é contratada para executá-lo. A investigação foi realizada junto a duas importantes organizações brasileiras, uma delas é empresa do setor público, e a outra, empresa da iniciativa privada, ambas com forte presença no setor da construção pesada de infraestrutura aeroportuária.

O conjunto de procedimentos sugerido para o planejamento da Administração de Contrato demanda orientação jurídica, dada a natureza da relação contratual. Essa orientação foi obtida por meio da realização de entrevista com um jurisconsulto, sendo essa a última etapa da metodologia empregada nesta dissertação.

A realização dos Estudos de Caso confirmou o referencial teórico estudado e proporcionou o conhecimento de visões variadas de como o Projeto e o contrato são administrados, oferecendo informações a respeito das diferentes prioridades dos dois ambientes. Já a entrevista proporcionou o alicerce legal do procedimento proposto, que constitui o objetivo principal do trabalho. 
Com a hierarquização das referências indispensáveis ao planejamento da Administração de Contrato, objeto deste trabalho, espera-se contribuir para a solução de disputas contratuais que, com freqüência, ocorrem no segmento de mercado estudado, dificultando a execução do Projeto ou até mesmo impedindo a sua continuidade.

Por derradeiro, ressalta-se que novos levantamentos poderão aprofundar a pesquisa realizada e, em conseqüência, refinar o conjunto de procedimentos sugerido. A título de indicação de futuro trabalho, tem-se o estudo dos pontos críticos à formação de contrato de gerenciamento da execução de empreendimentos ligados ao setor de serviços ou de obras empreitadas. 


\section{REFERÊNCIAS BIBLIOGRÁFICAS *}

AMARAL, Antônio Carlos Cintra. Licitação e contrato administrativo: estudos, pareceres e comentários. Belo Horizonte: Fórum, 2006a.

Referencial jurídico para orientar a ação do gerente. São Paulo. Centro de Estudos sobre Licitações e Contratos - CELC, 30 nov. 2006. Entrevista exclusiva concedida a Roberto Ricardino. São Paulo, 2006b.

ANDRIOLO, Francisco Rodrigues; MAIONCHI, Alberto; RICARDINO, Roberto. Uncertainty evaluation - risk management: accidents, incidents, failures, responsabilities, and cost. In: VINGTIÈME CONGRÈS DES GRANDS BARRAGES, 2000, Beijing. Proceedings Volume I-Question 76: The use of risk analysis to support dam safety decisions and management - Report R. 45. Beijing: International Comission On Large Dams, 2000, p. 701 714.

ASSOCIAÇÃO BRASILEIRA DE NORMAS TÉCNICAS. ABNT ISO/IEC Guia 73: Gestão de riscos: vocabulário: recomendações para uso em normas. Rio de Janeiro, 2005.

BRAMBLE, Barry B.; D’ONOFRIO, Michael F.; STETSON, John B. Avoiding and resolving construction claims. Kingston (USA): R. S. Means, 1990.

; CALLAHAN, Michael T. Avoiding and minimizing claims. In: Construction delay claims. $3^{\text {rd }}$ ed. New York: Aspen Law \& Business, 2000.

CARNELUTTI, Francesco. Cómo nace el derecho. 3. ed. Bogotá: Editorial Temis, 2000.

CARUTH, Donald L.; STOVALL, Steven Austin. NTC's American Business Terms Dictionary. Chicago: National Textbook Company, 1995.

CAVENDISH, Penny; MARTIN, Martin D. Negotiating and contracting for project management. In: PROJECT MANAGEMENT INSTITUTE. Principles of project management: collected handbooks from the Project Management Institute. Newtown Square (USA): Project Management Institute, 1997.

CHAPMAN, Chris; WARD, Stephen. Project risk management: processes, techniques and insights. Chichester (UK): John Wiley, 1997.

\footnotetext{
* Utilizada a norma ABNT NBR 6023 (2002) na elaboração desta lista.
} 
CLELAND, David I.; IRELAND, Lewis R. Project manager's portable handbook. $2^{\text {nd }}$ ed. New York: McGraw Hill, 2004.

COLLIER, Keith. Construction contracts. $2^{\text {nd }}$ ed. New Jersey: Prentice Hall, 1987.

COPPI, Douglas F.; MCWHORTER, Val S.; WULFF, Randall W. Mediation strategies. In: CUSHMAN, Robert F. et al. Proving and pricing construction claims. $3^{\text {rd }}$ ed. New York: Aspen Law \& Business, 2001.

COOLEY, John W.; LUBET, Steven. Advocacia de arbitragem. Brasília: Editora Universidade de Brasília; São Paulo: Imprensa Oficial do Estado, 2001.

DAEMON, Dalton; COLAIACOVO, Juan Luis; SIERRA, J. Alberto Nava. Negociações comerciais internacionais. Rio de Janeiro: Editora da Fundação Getúlio Vargas, 1982.

DINSMORE, Paul Campbell; CAVALIERI, Adriane (Coord.). Como se tornar um profissional em gerenciamento de projetos. 2. ed. Rio de Janeiro: Qualitymark, 2005.

DINSMORE, Paul Campbell; SILVEIRA NETO, Fernando Henrique. Gerenciamento de projetos e o Fator Humano - Conquistando resultados através das pessoas. Rio de Janeiro: Qualitymark, 2005.

DRBF Dispute Resolution Board Foundation. Practices and procedures. Seattle: The DRBF, 2004. Disponível em: < http://www.drb.org/manual_access.htm>. Acesso em 22 ago. 2006.

FIDIC - FÉDÉRATION INTERNATIONALE DES INGÉNIEURS-CONSEILS. Conditions of contract for EPC turnkey projects: general conditions ("Silver book"). Lausanne: FIDIC, 1999.

FISHER, Roger; URY, William; PATTON, Bruce. Como chegar ao sim: a negociação de acordos sem concessões. 2. ed. Rio de Janeiro: Imago, 1994.

FLEURY, Afonso; FLEURY, Maria Tereza Leme. Estratégias empresariais e formação de competências: um quebra-cabeça caleidoscópico da indústria brasileira. São Paulo: Atlas, 2000.

FRISBY, Thomas N. How to survive (and prosper) in construction. Kingston (USA): R. S. Means, 1990.

GARRETT, Gregory A. Glossary of key contract management terms. In: World class contracting: how winning companies build successful partnership in the e-business age. [S.I.: s.n.], [ca. 2000]. 
GIL, Antônio Carlos. Como elaborar projetos de pesquisa. 4. ed. São Paulo: Atlas, 2002.

GOMES, Orlando. Contratos. Atualização de Humberto Theodoro Júnior. 25. ed. Rio de Janeiro: Forense, 2002.

HAESE, Glenn H.; DRAGELIN, Timothy J. Types of claims. In: CUSHMAN, Robert F. et al. Proving and pricing construction claims. $3^{\text {rd }}$ ed. New York: Aspen Law \& Business, 2001.

HARRIS, Frank; McCAFFER, Ronald. Construction management: manual de gestión de proyecto y dirección de obra. Barcelona: Gustavo Gili, 1999.

INSTITUTION OF CIVIL ENGINEERS \& Association of Consulting Engineers; Federation of Civil Engineering Contractors. ICE conditions of contract. $6^{\text {th }}$ ed. London: Thomas Telford, 1991.

JUNQUEIRA, Luiz Augusto Costacurta. Negociação: tecnologia e comportamento. $4^{\mathrm{a}} \mathrm{ed}$. Rio de Janeiro: COP Editora, 1987.

KERZNER, Harold. Project management: a systems approach to planning, scheduling and controlling. $7^{\text {th }}$ ed. New York: Wiley, 2001.

Gestão de projetos: as melhores práticas. 2. ed. Porto Alegre: Bookman, 2006 a.

Project management workbook and PMP/CAPM exam study guide. $9^{\text {th }} \mathrm{ed}$. New York: Wiley, 2006b.

LIEBING, Ralph H. Construction contract administration. New Jersey: Prentice Hall, 1998.

MATOS, Francisco Gomes. Negociação gerencial: aprendendo a negociar. Rio de Janeiro: José Olympio, 1985.

McCONVILLE, John G. Managing Construction Purchasing. Kingston (EUA): R. S. Means, 1993.

McMANUS, Timothy C.; JENTZEN, Gary H.; GREENBERG, Gary. Preparation and presentation of claims. In: BRAMS, Robert S.; LERNER, Christopher. Construction claims deskbook-Management, documentation, and presentation of claims. New York: Aspen Law \& Business, 1996.

MARTIN, Martin D.; TEAGARDEN, C. Claude; LAMBRETH, Charles F. Contract administration for the project manager. In: PROJECT MANAGEMENT INSTITUTE. 
Principles of project management: collected handbooks from the Project Management Institute. Newtown Square (USA): Project Management Institute, 1997.

MEREDITH, Jack R.; MANTEL JR., Samuel J. Administração de projetos: uma abordagem gerencial. 4. ed. Rio de Janeiro: LTC, 2003.

MINTZBERG, Henry; WESTLEY, Frances. Tomada de decisões: não é bem o que se pensa. Revista Portuguesa de Gestão, Lisboa, Ano 16, n. 2, p. 13-18, abr.-jun. 2001.

NAZARETH, Eliana Riberti. Mediação: algumas considerações. Revista do Advogado, São Paulo, Ano XXVII, n. 87, p. 129-133, set. 2006.

NIERENBERG, Gerard I. The complete negotiator. New York: Nierenberg \& Zeif Publishers, 1986.

PEDROSA, Verônica de Andrade; ROCHA LIMA JR., João. Reivindicações em contratos de empreitada no Brasil. São Paulo, EPUSP, 1994 (Boletim técnico da Escola Politécnica da USP. Departamento de Engenharia de Construção Civil, BT/PCC/124, 20 p.)

PMI - PROJECT MANAGEMENT INSTITUTE. A guide to the project management body of knowledge. Upper Darby (USA): Project Management Institute Standards Committee, 1996.

Um guia do conjunto de conhecimentos do gerenciamento de projetos: $P M B O K$

Guide: edição 2000. Newtown Square (USA): Project Management Institute, 2002.

Um guia do conjunto de conhecimentos em gerenciamento de projetos: Guia PMBOK - Terceira edição. Newtown Square (USA): Project Management Institute, 2004.

REA, Louis M.; PARKER, Richard A. Metodologia de pesquisa: do planejamento à execução. São Paulo: Pioneira, 2000.

RICARDINO, Roberto. Análise (ou formulação) de reivindicações pelo Gerente de Contrato. São Paulo. Centro de Estudos sobre Licitações e Contratos - CELC, 9 nov. 2006. Palestra proferida por ocasião do Seminário CELC-462/06 sobre "Reequilíbrio Econômicofinanceiro dos Contratos Administrativos". São Paulo, 2006.

ROCHA, Renê Marcelo. Gerenciamento dos riscos: uma abordagem de processos e práticas para aplicaşão junto às empreiteiras de obras públicas de infra-estrutura urbana no município de São Paulo. 2005. 236 f. Dissertação (Mestrado em Engenharia) - Escola Politécnica da Universidade de São Paulo, São Paulo, 2005. 
ROJAS B., Claudia Lucía; MALDONADO, Humberto Orduz. Cómo redactar un contrato. Bogotá: Editorial Temis, 2003.

ROLDÃO, Victor Sequeira. Gestão de projectos: uma perspectiva integrada. Lisboa: Monitor, 2000.

SAMPAIO, Rogério Marrone de Castro. Direito Civil: contratos. 5. ed. São Paulo: Atlas, 2004.

SCHWARTZKOPF, William. Calculating lost labor productivity in construction claims. New York: Aspen Publishers, 1995.

; MCNAMARA, John J. Calculating construction damages. $2^{\text {nd }}$ ed. New York: Aspen Law \& Business, 2001.

SCHUYLER, John. Risk and decision analysis in projects. $2^{\text {nd }}$ ed. Newtown Square (USA): Project Management Institute, 2001.

SPARKS, Donald B. The dynamics of effective negotiation: a win-win approach to getting what you want. Houston (USA): Gulf, 1986.

STARK, Peter B. Aprenda a negociar: o manual de táticas ganba-ganha. 2. ed. São Paulo: Littera Mundi, 1999.

THOMPSON, Peter A.; PERRY, John G. Engineering construction risks: a guide to project risk analysis and assessment. London: Thomas Telford, 1998.

YASBEK, Jorge Arnaldo Curi. PMO (Project Management Office): estudo de aplicação para empresas construtoras de obras de infra-estrutura. 2005. 200 f. Dissertação (Mestrado em Engenharia) Escola Politécnica da Universidade de São Paulo, São Paulo, 2005.

YIN, Robert K. Estudo de caso: planejamento e métodos. 3. ed. Porto Alegre: Bookman, 2005.

WIDEMAN, R. Max. Project and program risk management: a guide to managing project risks and opportunities. Upper Darby (USA): Project Management Institute, 1992.

WYSOCKI, Robert K.; LEWIS, James P. The world class project manager: a professional development guide. New York: Perseus Publishing, 2000. 


\section{BIBLIOGRAFIA CONSULTADA *}

ALQUIER, Anne Marie et al. Analysis of external and internal risks in project early phase. In: SLEVIN, Dennis P.; CLELAND, David I.; PINTO, Jeffrey K. The frontiers of project management research. Newtown Square (USA): Project Management Institute, 2002.

ALVAREZ, Fausto. As competências para o século XXI. [Depoimento a Carolina Sanchez Miranda]. Gazeta Mercantil, São Paulo, 28 jul. 2005, Plano Pessoal, Caderno C, p. C-8.

AMARAL, Antônio Carlos Cintra. Comentando as licitações públicas. Série "Grandes Nomes", Vol. III. Rio de Janeiro: Temas \& Idéias, 2002.

; RICARDINO, Roberto. O BDI (Benefício e Despesas Indiretas) e o reequilíbrio econômico-financeiro dos contratos administrativos. In: AMARAL, Antônio Carlos Cintra.

Licitação e contrato administrativo: estudos, pareceres e comentários. Belo Horizonte: Fórum, 2006.

AMENDOLARA, Leslie. Técnicas de elaboração de contratos. 2. ed. São Paulo: Quartier Latin, 2004.

ASSOCIAÇÃO BRASILEIRA DE NORMAS TÉCNICAS. NBR ISO 10006: Gestão da qualidade: diretrizes para a qualidade no gerenciamento de projetos. Rio de Janeiro, 2000.

BACA, Claudia. Project manager's spotlight on change management. Alameda (USA): Harbor Light Press, 2005.

BERNSTEIN, Peter L. Desafio aos deuses: a fascinante história do risco. Rio de Janeiro: Campus, 1997.

BRAMS, Robert S.; LERNER, Christopher. Construction claims deskbook: management, documentation, and presentation of claims. New York: Aspen Law \& Business, 1997.

CAMPOS, Vicente Falconi. Gerenciamento da rotina do trabalho do dia-a-dia. 6. ed. Belo Horizonte: EDG, 1999.

CHAPMAN, Chris; WARD, Stephen. Project risk management: the required transformations to become project uncertainty management. In: SLEVIN, Dennis P.; CLELAND, David I.; PINTO, Jeffrey K. The frontiers of project management research. Newtown Square (USA): Project Management Institute, 2002.

\footnotetext{
* Utilizada a norma ABNT NBR 6023 (2002) na elaboração desta lista.
} 
CHIARADIA, Benedito Dantas. O novo Código Civil e os contratos administrativos da Lei $\boldsymbol{n}^{\boldsymbol{o}} \mathbf{8 . 6 6 6 / 9 3}$. Rio de Janeiro: Temas e Idéias, 2003.

CLELAND, David I. Project management strategic design and implementation. $3^{\text {rd }} \mathrm{ed}$. New York: McGraw-Hill, 1999.

; KING, William R. Project management handbook. $2^{\text {nd }}$ ed. New York: Van Nostrand Reinhold, 1988.

CODA, Roberto. Saber conciliar, dom do brasileiro. (Entrevista a Angélica Vilela). Gazeta Mercantil, São Paulo, 23 set. 2002, p. C-2.

CRAWFORD, Lynn. Profiling the competent project. In: SLEVIN, Dennis P.; CLELAND, David I.; PINTO, Jeffrey K. The frontiers of project management research. Newtown Square (EUA): Project Management Institute, 2002.

DOMINGUES, Heron. Sucesso em projetos: metodologia ou habilidades pessoais. [S.I.: s.n.], [ca. 2004]. Não paginado.

DOWNING, Douglas; CLARK, Jeffrey. Estatística aplicada. São Paulo: Saraiva, 1998.

FIDIC - FÉDÉRACION INTERNATIONALE DES INGÉNIEURS-CONSEILS.

Conditions of contract for construction: for building and engineering works designed by the employer ("Red book"). Lausanne: FIDIC, 1999.

FORSBERG, Kevin; MOOZ, Hal; COTTERMAN, Howard. Visualizing project management: a model for business and technical success. $2^{\text {nd }}$ ed. New York: Wiley, 2000.

GUDER, Robert F. Negotiating techniques: how to work toward a constructive agreement. Fairfield (EUA): The Economics Press, 1985.

HELDMAN, Kim. Project manager's spotlight on risk management. Alameda (USA): Harbor Light Press, 2005.

HUNGER, J. David; WHEELEN, Thomas L. Gestão estratégica: princípios e prática. 2. ed. Rio de Janeiro: Reichmann \& Affonso, 2002.

LEESER, Robert C. Engineer's Procurement Manual for Major Plant Equipment: a guide to principles and procedures. New Jersey: Prentice Hall, 1996. 
MINTZBERG, Henry; LAMPEL, Joseph. Reflexão sobre o processo estratégico. Revista Portuguesa de Gestão, Lisboa, Ano 15, n. 2, p. 24-34, abr.-jun. 2000.

Project manager competency development (PMCD) framework. Newtown Square (EUA): Project Management Institute, 2002.

PLATÃO. As Leis (incluindo Epinomis). Tradução de Edson Bini. São Paulo: EDIPRO, 1999.

RICARDINO, Roberto. Utilização da FIDIC na negociação de contratos EPC. São Paulo. Construções e Comércio Camargo Corrêa S/A, 21 maio 2002. Palestra proferida por ocasião do $5^{\circ}$ Simpósio de Administração Contratual - V ADCON. São Paulo, 2002.

RICHARDSON, Robert Jarry et al. Pesquisa social: métodos e técnicas. 3 ed. São Paulo: Atlas, 1999.

RICHTER, Irvin E. Are construction claims inevitable? International Construction, [S.I.:s.n.], p. 69-73, maio 1982.

ROCHA LIMA JR., João. Gerenciamento na Construção Civil - Uma abordagem sistêmica. São Paulo, EPUSP, 1988 (Boletim técnico da Escola Politécnica da USP. Departamento de Engenharia de Construção Civil, 47 p.).

Qualidade do empreendimento na Construção Civil - Inovação e competitividade. São Paulo, EPUSP, 1995 (Boletim técnico da Escola Politécnica da USP. Departamento de Engenharia de Construção Civil, BT/PCC/144, 44 p.).

SCOTT, Bill. $\boldsymbol{A}$ arte de negociar. Lisboa: Editorial Presença, 1988.

SHELL, G. Richard. Bargaining for advantage: negotiation strategies for reasonable people. New York: Viking, 1999.

SIMON, Michael S. Construction contracts and claims. New York: McGraw-Hill, 1979.

TRAUNER JR., Theodore J. Construction Delays. Kingston (USA): R. S. Means, 1990.

VALERIANO, Dalton L. Gerenciamento estratégico e administração por projetos. São Paulo: Makron, 2001.

WILLE, Silvio Aurélio de Castro; HUGUE, Simone Dall'Oglio. Reivindicações: como gerenciar em projetos. Revista Mundo PM, Curitiba, ano 1, número 03, p. 16-21, jun.-jul. 2005. 


\section{APÊNDICE A}

Questionário aplicado aos Estudos de Caso 1 e 2

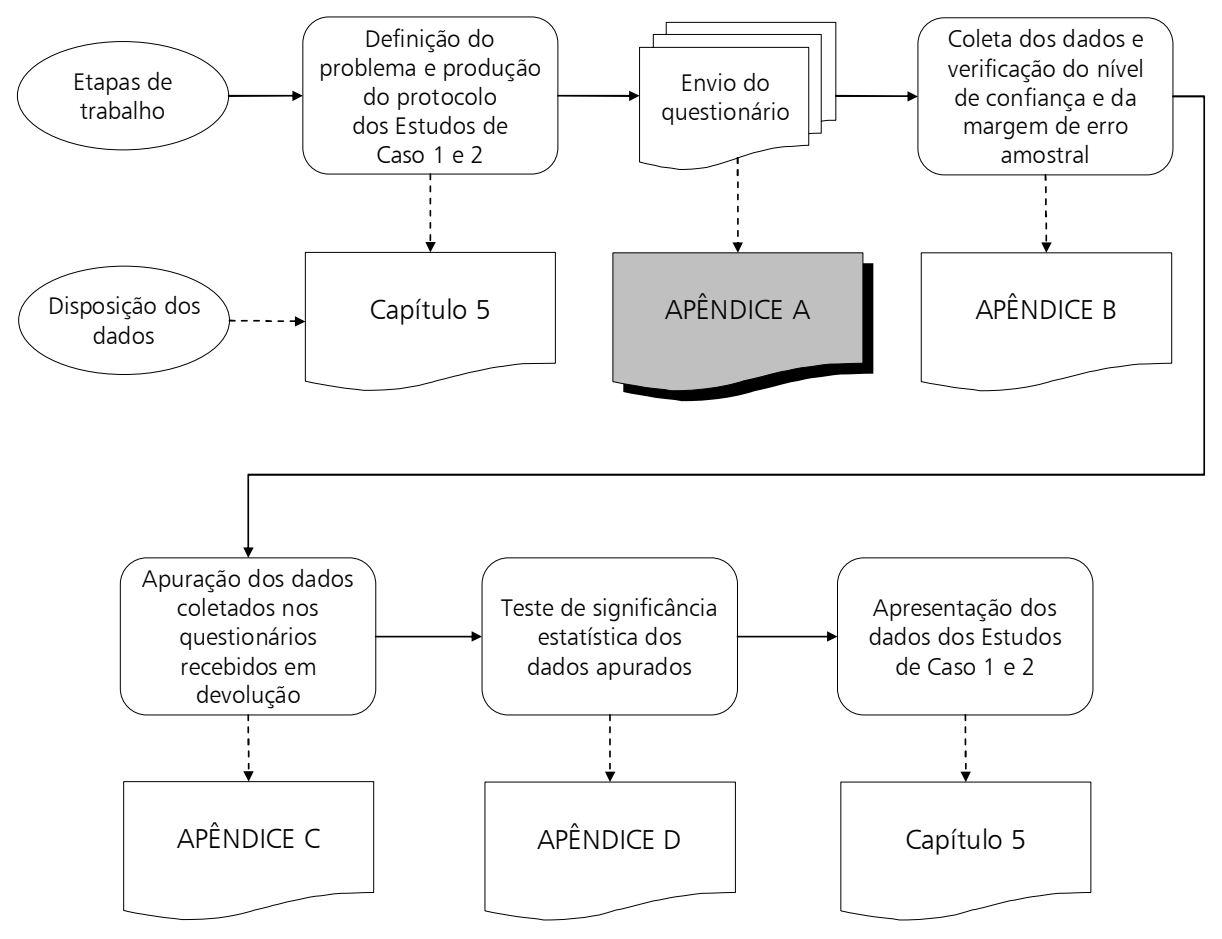




\section{PERFIL DOS ENTREVISTADOS}

As solicitações desta Seção dizem respeito à sua experiência profissional, contada a partir da data de graduação. Nas contagens de tempo, considere a experiência vivida na Empresa e em outras empresas nas quais tenha trabalhado ou prestado serviço.

1 Assinale com um " $X$ " a sua formação profissional:
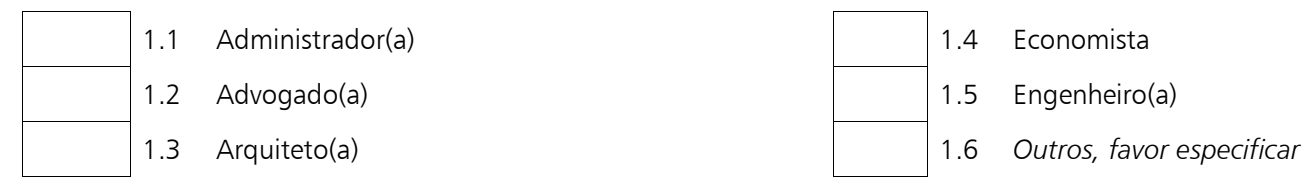

2 Assinale com um " $X$ " o seu tempo de experiência profissional:

\begin{tabular}{|l|ll}
\hline .1 & Menos de 3 anos \\
2.2 & De 3 a 5 anos \\
2.3 & De 6 a 10 anos
\end{tabular}

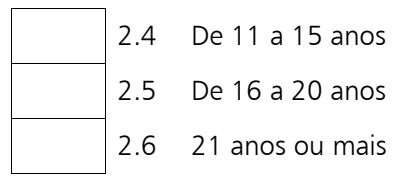

3 Assinale com um " $\mathrm{X}$ " o seu tempo de lotação em canteiros de obras:

\begin{tabular}{|l|ll}
\hline & 3.1 & Nenhum \\
3.2 & Menos de 3 anos \\
3.3 & De 3 a 5 anos
\end{tabular}

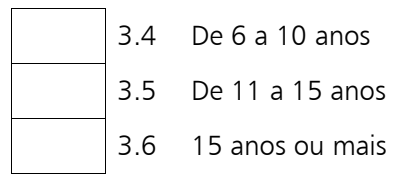

4 Assinale com um " $X$ " o regime de execução dos contratos dos quais Você participou e está participando:

\begin{tabular}{|l|ll}
\hline & 4.1 & Empreitada integral \\
4.2 & Empreitada por preço global \\
4.3 & Empreitada por preço unitário
\end{tabular}

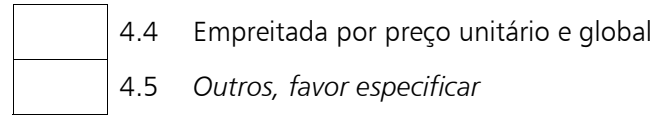

5 Assinale com um " $X$ " o seu tempo de experiência em Administração de Contrato:
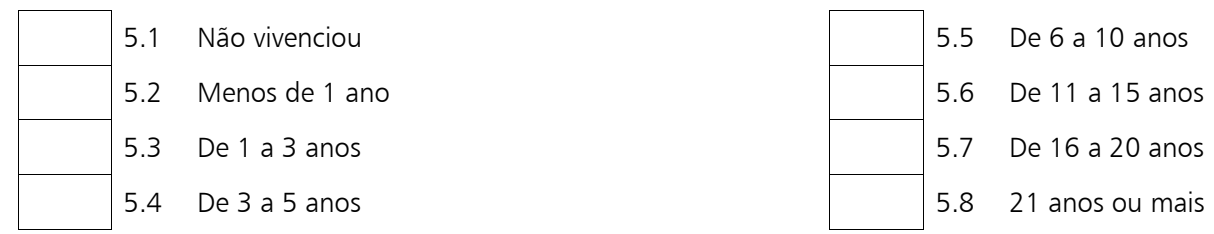

\section{APRENDIZADO DA ADMINISTRAÇÃO DE CONTRATO}

6 Classifique os meios de aprendizagem da Administração de Contrato, por ordem decrescente de importância, assinalando com "1" o meio que Você considera o primeiro em importância, "2" o segundo, "3" o terceiro e assim sucessivamente:

\begin{tabular}{|l|ll}
\hline & 6.1 & Com base em cursos acadêmicos \\
6.2 & Com base na intuição \\
6.3 & Com base na observação do dia-a-dia \\
6.4 & Com base no exemplo do líder
\end{tabular}

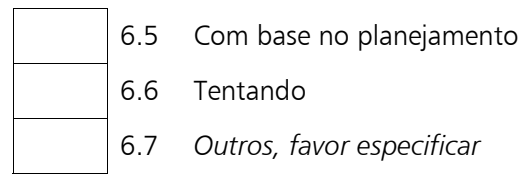




\section{GERENCIAMENTO DE PROJETOS}

7 Classifique os fatores que mais influem no Gerenciamento de Projetos, por ordem decrescente de importância, assinalando com "1" o meio que Você considera o primeiro em importância, "2" o segundo, "3" o terceiro, e assim sucessivamente:

\begin{tabular}{|l|ll|}
\hline & 7.1 & Abrangência do escopo \\
\hline & 7.2 & Acompanhamento e avaliação progressiva \\
\hline & 7.3 & Aquisição de materiais de construção \\
\hline & 7.4 & Avaliação estratégica da complexidade \\
\hline & 7.5 & Caminho crítico da gestão \\
\hline & 7.6 & Memória técnica da execução \\
\hline & 7.7 & Designação das pessoas da equipe \\
\hline & 7.8 & Detalhamento da estimativa \\
\hline 7.9 & Estimativa do custo \\
\hline 7.10 & Finalização do projeto \\
\hline 7.11 & Gestão do custo \\
\hline 7.12 & Organização do projeto \\
\hline 7.13 & Planejamento do projeto \\
\hline 7.14 & Produtividade da mão de obra de execução \\
\hline 7.15 & Produtividade na operação de equipamentos \\
\hline 7.16 & Software para gerenciamento do projeto \\
\hline 7.17 & Outros, favor especificar \\
\hline
\end{tabular}

8 Pontue, em números inteiros, os fatores influentes no Gerenciamento de Projetos, utilizando a seguinte graduação:

\begin{tabular}{lr}
\hline$A=$ Concordo & 81 a 100 pontos \\
$B=$ Concordo parcialmente & 61 a 80 pontos \\
$C=$ Neutro & 41 a 60 pontos \\
$D=$ Discordo parcialmente & 21 a 40 pontos \\
$E=$ Discordo & 0 a 20 pontos \\
\hline
\end{tabular}

\begin{tabular}{|ll|l|l|l|l|l|}
\cline { 5 - 6 } \multicolumn{1}{r|}{ Fatores } & A & B & C & D & E \\
\hline 8.1 & Abrangência do escopo & & & & & \\
\hline 8.2 & Acompanhamento e avaliação progressiva & & & & & \\
\hline 8.3 & Aquisição de materiais de construção & & & & & \\
\hline 8.4 & Avaliação estratégica da complexidade & & & & & \\
\hline 8.5 & Caminho crítico da gestão & & & & & \\
\hline 8.6 & Memória técnica da execução & & & & & \\
\hline 8.7 & Designação das pessoas da equipe & & & & & \\
\hline 8.8 & Detalhamento da estimativa & & & & & \\
\hline 8.9 & Estimativa do custo & & & & & \\
\hline 8.10 & Finalização do projeto & & & & & \\
\hline
\end{tabular}

(Continua) 
(Conclusão)

\begin{tabular}{|ll|c|c|c|c|c|}
\cline { 5 - 6 } \multicolumn{2}{c|}{ Fatores } & A & B & C & D & E \\
\hline 8.11 & Gestão do custo & & & & & \\
\hline 8.12 & Organização do projeto & & & & & \\
\hline $8.13 \quad$ Planejamento do projeto & & & & & \\
\hline $8.14 \quad$ Produtividade da mão de obra de execução & & & & & \\
\hline $8.15 \quad$ Produtividade na operação de equipamentos & & & & & \\
\hline 8.16 & Software para gestão do projeto & & & & & \\
\hline $8.17 \quad$ Outros, favor especificar & & & & & \\
\hline
\end{tabular}

9 Classifique as habilidades técnicas do gerente, que mais influem no Gerenciamento de Projetos, por ordem decrescente de importância, assinalando com "1" o meio que Você considera o primeiro em importância, "2" o segundo, "3" o terceiro e assim sucessivamente:

\begin{tabular}{|l|ll|}
\hline & 9.1 & Administração simultânea de múltiplas prioridades \\
\hline & 9.2 & Ajuste do estilo de liderança ao longo da execução \\
\hline 9.3 & Avaliação do empreendimento como um todo \\
\hline 9.4 & Conceito das funçães do processo de gestão \\
\hline 9.5 & Conhecimento das próprias forças e fraquezas \\
\hline 9.6 & Delegação \\
\hline 9.7 & Desempenho (método de trabalho) do gerente \\
\hline 9.8 & Desenvolvimento das pessoas \\
\hline 9.9 & Escolha da melhor maneira de orçar \\
\hline 9.10 & Estratégia \\
\hline 9.11 & Integração da equipe \\
\hline 9.12 & Liderança \\
\hline 9.13 & Necessidades do Cliente \\
\hline 9.14 & Procedimentos e políticas \\
\hline 9.15 & Reuniões periódicas \\
\hline 9.16 & Seleção e mobilização da equipe \\
\hline 9.17 & Tática \\
\hline 9.18 & Visão da oportunidade \\
\hline 9.19 & Outros, favor especificar \\
\hline &
\end{tabular}

10 Pontue, em números inteiros, as habilidades técnicas do Gerente, influentes no Gerenciamento de Projetos, utilizando a seguinte graduação:

\begin{tabular}{lr}
\hline$A=$ Concordo & 81 a 100 pontos \\
$B=$ Concordo parcialmente & 61 a 80 pontos \\
$C=$ Neutro & 41 a 60 pontos \\
$D=$ Discordo parcialmente & 21 a 40 pontos \\
$E=$ Discordo & 0 a 20 pontos \\
\hline
\end{tabular}




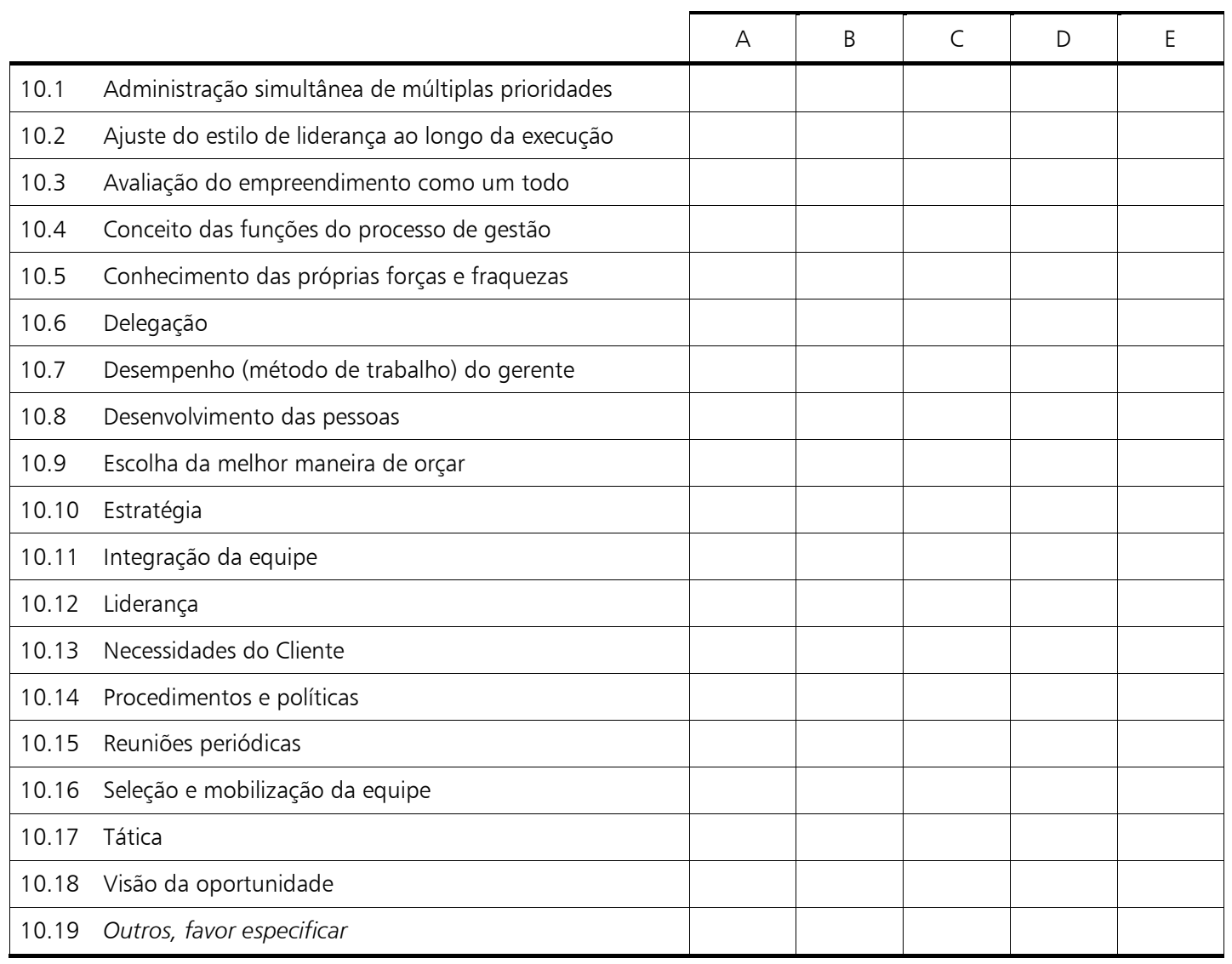

11 Classifique as habilidades pessoais do gerente, que mais influem no Gerenciamento de Projetos, por ordem decrescente de importância, assinalando com "1" o meio que Você considera o primeiro em importância, "2" o segundo, "3" o terceiro e assim sucessivamente:

\begin{tabular}{|l|ll|}
\hline & 11.1 & Comunicação escrita \\
\hline & 11.2 & Comunicação verbal \\
\hline & 11.3 & Criatividade \\
\hline & 11.4 & Estimulador/ Educador de pessoas \\
\hline & 11.5 & Flexibilidade \\
\hline & 11.6 & Influenciador \\
\hline & 11.7 & Negociação \\
\hline & 11.8 & Objetividade e clareza em apresentar/oferecer \\
\hline & 11.9 & Pensamento crítico/ Tomada de decisão \\
\hline & 11.10 & Sociabilidade \\
\hline & 11.11 & Solução de conflitos \\
\hline & 11.12 & Solução de problemas técnicos \\
\hline & 11.13 & Outros, favor especificar \\
\hline
\end{tabular}


12 Pontue, em números inteiros, as habilidades pessoais do Gerente, influentes no Gerenciamento de Projetos, utilizando a seguinte graduação:

\begin{tabular}{lr}
\hline$A=$ Concordo & 81 a 100 pontos \\
$B=$ Concordo parcialmente & 61 a 80 pontos \\
$C=$ Neutro & 41 a 60 pontos \\
$D=$ Discordo parcialmente & 21 a 40 pontos \\
$E=$ Discordo & 0 a 20 pontos \\
\hline
\end{tabular}

\begin{tabular}{|c|c|c|c|c|c|c|}
\hline & & \\
\hline & & A & B & C & $\mathrm{D}$ & $E$ \\
\hline 12.1 & Comunicação escrita & & & & & \\
\hline 12.2 & Comunicação verbal & & & & & \\
\hline 12.3 & Criatividade & & & & & \\
\hline 12.4 & Estimulador/ Educador de pessoas & & & & & \\
\hline 12.5 & Flexibilidade & & & & & \\
\hline 12.6 & Influenciador & & & & & \\
\hline 12.7 & Negociação & & & & & \\
\hline 12.8 & Objetividade e clareza em apresentar/oferecer & & & & & \\
\hline 12.9 & Pensamento crítico/ Tomada de decisão & & & & & \\
\hline 12.10 & Sociabilidade & & & & & \\
\hline 12.11 & Solução de conflitos & & & & & \\
\hline 12.12 & Solução de problemas técnicos & & & & & \\
\hline 12.13 & Outros, favor especificar & & & & & \\
\hline
\end{tabular}

\section{ADMINISTRAÇÃO DE CONTRATO}

13 Classifique os requisitos que mais influem na prática da Administração de Contrato, por ordem decrescente de importância, assinalando com "1" o meio que Você considera o primeiro em importância, "2" o segundo, "3" o terceiro e assim sucessivamente:

\begin{tabular}{|l|ll|}
\hline & 13.1 & Apoio jurídico \\
\hline & 13.2 & Competência na negociação \\
\hline & 13.3 & Compreensão da base legal \\
\hline & 13.4 & Compreensão da base técnica \\
\hline & 13.5 & Conhecimento sobre o Cliente \\
\hline & 13.6 & Coordenação de interfaces \\
\hline & 13.7 & Documentação e arquivo \\
\hline & 13.8 & Domínio do escopo do contrato \\
\hline & 13.9 & Equipe qualificada \\
\hline & 13.10 & Integração de atividades multifuncionais \\
\hline 13.11 & Liderança \\
\hline & 13.12 & Orçamento como conseqüência do planejamento \\
\hline & 13.13 & Postura ganha-ganha \\
\hline 13.14 & Registro de fatos \\
\hline 13.15 & Outros, favor especificar \\
\hline
\end{tabular}


14 Pontue, em números inteiros, os requisitos influentes na prática da Administração de Contrato, utilizando a seguinte graduação:

\begin{tabular}{|c|c|}
\hline$A=$ Concordo & 81 a 100 pontos \\
\hline $\mathrm{B}=$ Concordo parcialmente & 61 a 80 pontos \\
\hline$C=$ Neutro & 41 a 60 pontos \\
\hline $\mathrm{D}=$ Discordo parcialmente & 21 a 40 pontos \\
\hline$E=$ Discordo & 0 a 20 pontos \\
\hline
\end{tabular}

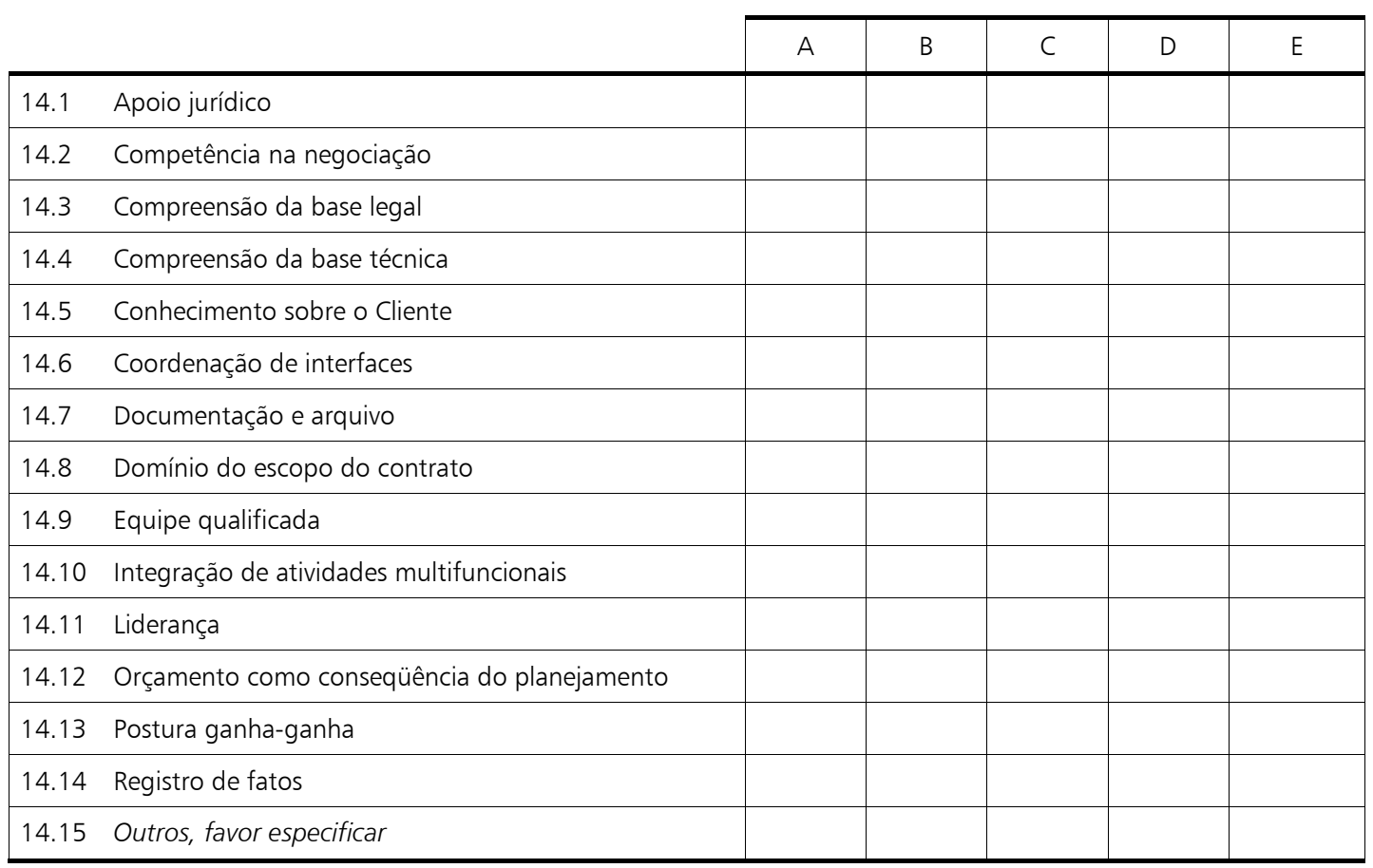

15 Classifique os fatores que afetam o atendimento de reivindicação contratual formalmente apresentada, por ordem decrescente de importância do fator, assinalando com "1" o meio que Você considera o primeiro em importância, "2" o segundo, "3" o terceiro e assim sucessivamente:

\begin{tabular}{|l|ll|}
\hline & 15.1 & Ambiente no canteiro de obra \\
\hline & 15.2 & Clareza do texto \\
\hline & 15.3 & Documentação de suporte \\
\hline & 15.4 & Domínio do Projeto por parte do Gerente da empresa \\
\hline & 15.5 & Domínio do Projeto por parte da equipe do Gerente \\
\hline & 15.6 & Existência de registro dos fatos ocorridos \\
\hline & 15.7 & Fundamentação legal da reivindicação \\
\hline & 15.8 & Fundamentação técnica da reivindicação \\
\hline & 15.9 & Momento do Projeto \\
\hline & 15.10 & Pontualidade no cumprimento do cronograma físico \\
\hline & 15.11 & Procedimento de decisão da outra parte \\
\hline 15.12 & Qualidade da execução do Projeto \\
\hline & 15.13 & Outros, favor especificar \\
\hline
\end{tabular}


16 Pontue, em números inteiros, os fatores que afetam o atendimento de reivindicação contratual, formalmente apresentada pelo Gerente da Empresa à Contratante, atribuindo pontos a cada requisito, utilizando a seguinte graduação:

\begin{tabular}{lr}
\hline$A=$ Concordo & 81 a 100 pontos \\
$B=$ Concordo parcialmente & 61 a 80 pontos \\
$C=$ Neutro & 41 a 60 pontos \\
$D=$ Discordo parcialmente & 21 a 40 pontos \\
$E=$ Discordo & 0 a 20 pontos \\
\hline
\end{tabular}

\begin{tabular}{|c|c|c|c|c|c|c|}
\hline & & \\
\hline & & A & B & C & $\mathrm{D}$ & $E$ \\
\hline 16.1 & Ambiente no canteiro de obra & & & & & \\
\hline 16.2 & Clareza do texto & & & & & \\
\hline 16.3 & Documentação de suporte & & & & & \\
\hline 16.4 & Domínio do Projeto por parte do Gerente da Empresa & & & & & \\
\hline 16.5 & Domínio do Projeto por parte da equipe do Gerente & & & & & \\
\hline 16.6 & Existência de registro dos fatos ocorridos & & & & & \\
\hline 16.7 & Fundamentação legal da reivindicação & & & & & \\
\hline 16.8 & Fundamentação técnica da reivindicação & & & & & \\
\hline 16.9 & Momento do Projeto & & & & & \\
\hline 16.10 & Pontualidade no cumprimento do cronograma físico & & & & & \\
\hline 16.11 & Procedimento de decisão da outra parte & & & & & \\
\hline 16.12 & Qualidade da execução do Projeto & & & & & \\
\hline 16.13 & Outros, favor especificar & & & & & \\
\hline
\end{tabular}

FIM DO QUESTIONÁRIO 


\section{APÊNDICE B}

Nível de confiança e margem de erro amostral

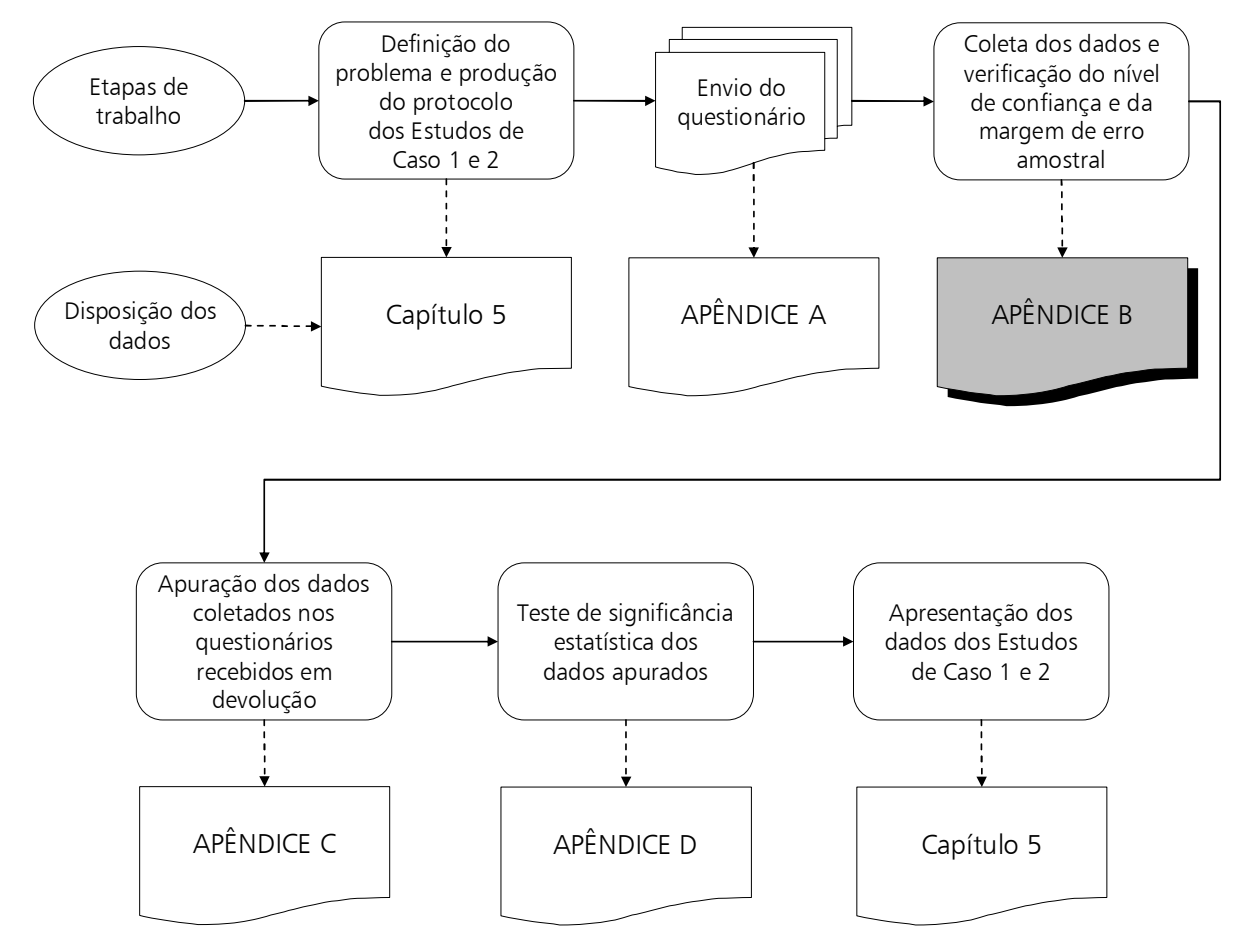


O APÊNDICE B demonstra o cálculo efetuado para avaliar a margem de erro amostral da pesquisa realizada. O cálculo da margem de erro amostral, para um determinado nível de confiança, desenvolve-se a partir da expressão indicada na Equação B.1 que, segundo Rea e Parker (2000), é própria para pequenas populações, como acontece nos Estudos de Caso 1 e 2.

$$
n=\frac{\mathrm{Z}_{\alpha}^{2}[p(1-p)] N}{\mathrm{Z}_{\alpha}^{2}[p(1-p)]+(N-1) C_{p}^{2}}
$$

onde:

$n$ = tamanho específico da amostra;

$N$ = tamanho do universo;

$\mathrm{Z} \alpha=$ contagem da estatística $\mathrm{Z}$ para vários níveis de confiança $(\alpha)$;

$C p=$ intervalo de confiança em termos de proporções;

$p=$ verdadeira proporção da amostra.

FONTE: Rea e Parker (2000).

Equação B.1 - Fórmula de cálculo do tamanho da amostra.

Rea e Parker afirmam que a estatística $Z$ é “a conversão de desvios-padrão calculados em unidades padrão de distância em relação à média em distribuições normais" (2000, p. 243). Os autores citados consideram que o intervalo de confiança $\left(C_{p}\right)$ normalmente não deve exceder $10 \%$, sendo freqüentemente fixado na faixa de 3 a $5 \%$.

No Capítulo 5 desta dissertação viu-se que, à época do planejamento e coleta de dados da pesquisa, foi considerado que o tamanho do universo era de 100 gerentes no Estudo de Caso 1, e de 120 no Estudo de Caso 2. Esses tamanhos não puderam ser determinados com precisão. Por este motivo, o cálculo da margem de erro amostral foi efetuado considerando-se: (i) a oscilação de 5\%, para mais e para menos, dos tamanhos dos universos, e (ii) a adoção de 0,5 para valor de (p), como uma atitude conservadora.

Reescrevendo a Equação B.1 e resolvendo-a para o intervalo de confiança $\left(C_{p}\right)$, obtém-se, para determinados níveis de confiança, as respectivas margens de erro amostral para as hipóteses formuladas. Os resultados constam da Tabela B.1. 
Tabela B.1 - Matriz da margem de erro amostral dos Estudos de Caso.

\begin{tabular}{|c|c|c|c|c|c|c|c|}
\hline \multirow{2}{*}{$\begin{array}{l}\text { Níveis de } \\
\text { Confiança }\end{array}$} & \multirow{2}{*}{$\begin{array}{c}\text { Valores de } \\
\text { Z }\end{array}$} & \multicolumn{3}{|c|}{ Estudo de Caso 1} & \multicolumn{3}{|c|}{ Estudo de Caso 2} \\
\hline & & $N=95$ & $N=100$ & $N=105$ & $N=114$ & $N=120$ & $N=126$ \\
\hline $99 \%$ & 2,575 & 7,936 & 8,471 & 8,928 & 11,290 & 11,607 & 11,887 \\
\hline $98 \%$ & 2,335 & 7,196 & 7,682 & 8,095 & 10,237 & 10,526 & 10,779 \\
\hline $070 /$ & 2170 & 6680 & 7130 & 7523 & a 511 & 0782 & 10018 \\
\hline $9 / \%$ & $2,1 / 0$ & 6,688 & 7,139 & $1,5<3$ & 9,514 & 9,182 & 10,018 \\
\hline $96 \%$ & 2,055 & 6,334 & 6,760 & 7,125 & 9,010 & 9,263 & 9,487 \\
\hline $95 \%$ & 1,960 & 6,041 & 6,448 & 6,795 & 8,593 & 8,835 & 9,048 \\
\hline $94 \%$ & 1,885 & 5,810 & 6,201 & 6,535 & 8,264 & 8,497 & 8,702 \\
\hline $93 \%$ & 1,785 & 5,501 & 5,872 & 6,189 & 7,826 & 8,046 & 8,240 \\
\hline $92 \%$ & 1,755 & 5,409 & 5,774 & 6,085 & 7,695 & 7,911 & 8,102 \\
\hline $91 \%$ & 1,695 & 5,224 & 5,576 & 5,877 & 7,431 & 7,641 & 7,825 \\
\hline $90 \%$ & 1,645 & 5,070 & 5,412 & 5,703 & 7,212 & 7,415 & 7,594 \\
\hline
\end{tabular}

FONTE: $\quad$ Elaborado pelo autor.

LEGENDA: $\quad N=$ tamanho do universo.

OBSERVAÇÃO 1: Margens de erro amostral expressas em porcentagem.

OBSERVAÇÃO 2: O tamanho da amostra do Estudo de Caso 1 é $n=70$, e do Estudo de Caso 2 é $n=61$.

OBSERVAÇÃO 3: A área demarcada na Tabela revela as margens de erro amostral no intervalo de confiança de $95 \%$ a $97 \%$. 


\section{APÊNDICE C}

Tabulação das respostas ao questionário

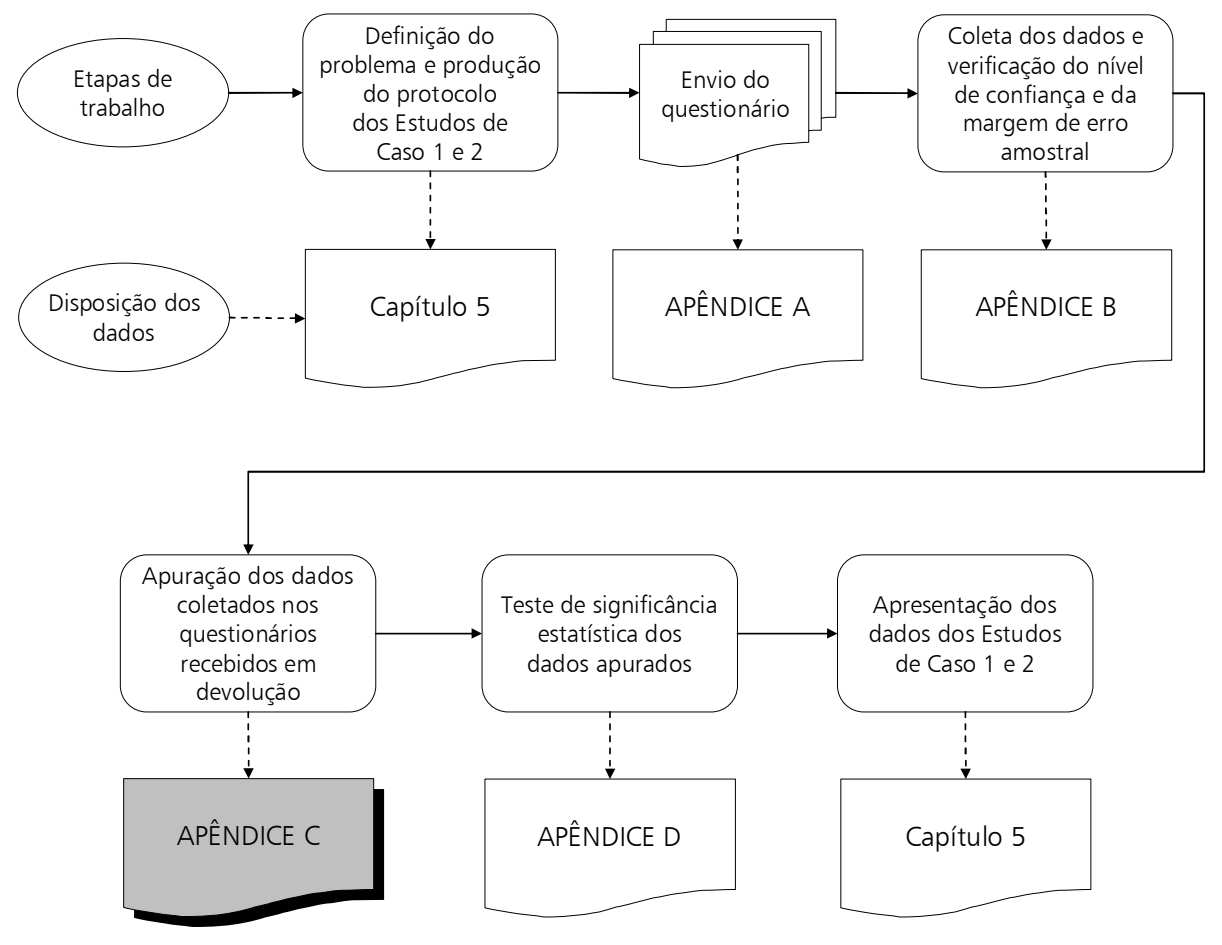


Este APÊNDICE C exibe as respostas dadas aos Quesitos do questionário constante do APÊNDICE A da dissertação, o qual foi aplicado aos Estudos de Caso 1 e 2. Os dados obtidos acham-se apresentados sob forma tabular, obedecendo à articulação mostrada no Quadro C.1.

\begin{tabular}{l|l|l}
\hline Quesitos do questionário & $\begin{array}{c}\text { Apresentação da freqüência } \\
\text { de respostas dos Quesitos }\end{array}$ & $\begin{array}{c}\text { Apresentação da posição } \\
\text { das variáveis dos Quesitos }\end{array}$ \\
\hline
\end{tabular}

(1) Formação profissional dos entrevistados

Tabela C.1

(2) Tempo de experiência profissional dos entrevistados

Tabela C.2

(3) Tempo de lotação dos entrevistados em canteiros de obras

Tabela C.3

(4) Experiência dos entrevistados em regimes de execução de contratos

Tabelas C.4, C.5, C.6 e C.7

(5) Tempo de experiência dos entrevistados em Administração de Contrato

Tabela C.8

(6) Meios de aprendizagem em Administração de Contrato

Tabela C.9

(7 e 8) Fatores que mais influem no Gerenciamento de Projetos

(9 e 10) Habilidades técnicas do Gerente, que mais influem no Gerenciamento de Projetos Gerenciamento de Projetos

(13 e 14) Requisitos que mais influem na prática da Administração de Contrato

(15 e 16) Fatores que afetam o atendimento de reivindicação contratual apresentada
Tabelas C.10 e C.11

Tabela C.12

Tabelas C.13 e C.14

Tabelas C.16 e C.17

\section{Tabelac.9}

1

$\underline{-}$

Tabela C.15

Tabela C.18

Tabelas C.19 e C.20

Tabela C.21

Tabelas C.22 e C.23

Tabela C.24

Quadro C.1 - Articulação das Tabelas do APÊNDICE C.

As Tabelas exibem a distribuição das freqüências relativa e ajustada de respostas dadas aos Quesitos do questionário, expressas em porcentagem. O cálculo das porcentagens de freqüência relativa foi feito com base no tamanho da amostra de cada Estudo de Caso, incluindo as respostas inválidas ou ausentes. Já o cálculo das porcentagens de freqüência ajustada foi feito com base somente nas respostas válidas, excluindo as respostas inválidas ou ausentes, conforme Rea e Parker (2000). 
As Tabelas integrantes deste APÊNDICE fornecem informações de duas naturezas ${ }^{32}$. A primeira, composta das Tabelas C.1 a C.10, revela o perfil dos entrevistados em cada Estudo de Caso, e a segunda, formada pelas Tabelas C.11 a C.25, mostra a posição hierárquica das variáveis referentes aos fatores, habilidades e requisitos pesquisados. Os resultados dos Estudos de Caso 1 e 2, apresentados no Capítulo 5, derivam desse último grupo de Tabelas.

Tabela C.1 - Respostas ao Quesito 1 e posição das suas variáveis.

\begin{tabular}{|c|c|c|c|c|c|c|}
\hline \multicolumn{3}{|c|}{ Estudo de Caso 1} & \multirow{2}{*}{$\begin{array}{l}\text { Formação profissional dos } \\
\text { entrevistados }\end{array}$} & \multicolumn{3}{|c|}{ Estudo de Caso 2} \\
\hline$f$ & $f(\%)$ & Posição & & Posição & $f(\%)$ & $f$ \\
\hline 1 & 1,43 & $5^{\circ}$ & Administrador (a) & $2^{\circ}$ & 4,92 & 3 \\
\hline 1 & 1,43 & $6^{\circ}$ & Advogado (a) & - & 0 & 0 \\
\hline 13 & 18,58 & $2^{\circ}$ & Arquiteto (a) & $4^{\circ}$ & 1,64 & 1 \\
\hline 1 & 1,43 & $7^{\circ}$ & Economista & $5^{\circ}$ & 1,64 & 1 \\
\hline 48 & 68,57 & $1^{\circ}$ & Engenheiro (a) & $1^{\circ}$ & 85,24 & 52 \\
\hline 2 & 2,85 & $3^{\circ}$ & Analista de sistemas & - & - & 0 \\
\hline 1 & 1,43 & $8^{\circ}$ & Bacharel em ciências de computação & - & - & 0 \\
\hline 0 & - & - & Contador & $3^{\circ}$ & 4,92 & 3 \\
\hline 2 & 2,85 & $4^{\circ}$ & Técnico em edificações & - & - & 0 \\
\hline 1 & 1,43 & $9^{\circ}$ & Tecnólogo & $6^{\circ}$ & 1,64 & 1 \\
\hline 70 & 100,00 & & & & 100,00 & 61 \\
\hline
\end{tabular}

FONTE: $\quad$ Pesquisa realizada pelo autor.

LEGENDA: $\quad f=$ freqüência de respostas.

OBSERVAÇÃO: As formações profissionais grafadas em itálico correspondem às indicações da opção Outros feitas pelos entrevistados.

32 A primeira espécie de informações provém dos Quesitos 1 a 6 da seção Perfil dos entrevistados em Administração de Contrato do questionário constante do APÊNDICE A, e a segunda, dos Quesitos 7 a 16 das seções Gerenciamento de Projetos e Administração de Contrato desse questionário. 
Tabela C.2 - Respostas ao Quesito 2 e posição das suas variáveis.

\begin{tabular}{|c|c|c|c|c|c|c|}
\hline \multicolumn{3}{|c|}{ Estudo de Caso 1} & \multirow{2}{*}{$\begin{array}{c}\text { Tempo de experiência profissional dos } \\
\text { entrevistados }\end{array}$} & \multicolumn{3}{|c|}{ Estudo de Caso 2} \\
\hline$f$ & $f(\%)$ & Posição & & Posição & $f(\%)$ & $f$ \\
\hline 3 & 4,29 & $6^{\circ}$ & Menos de 3 anos & $5^{\circ}$ & 6,56 & 4 \\
\hline 6 & 8,57 & $5^{\circ}$ & De 3 a 5 anos & $6^{\circ}$ & 4,92 & 3 \\
\hline 14 & 20,00 & $2^{\circ}$ & De 6 a 10 anos & $3^{\circ}$ & 14,75 & 9 \\
\hline 8 & 11,43 & $4^{\circ}$ & De 11 a 15 anos & $2^{\circ}$ & 16,39 & 10 \\
\hline 12 & 17,14 & $3^{\circ}$ & De 16 a 20 anos & $4^{\circ}$ & 11,48 & 7 \\
\hline 27 & 38,57 & 10 & 21 anos ou mais & $1^{\circ}$ & 45,90 & 28 \\
\hline 70 & 100,00 & & & & 100,00 & 61 \\
\hline
\end{tabular}

FONTE: Pesquisa realizada pelo autor.

LEGENDA: $f=$ freqüência de respostas.

Tabela C.3 - Respostas ao Quesito 3 e posição das suas variáveis.

\begin{tabular}{|c|c|c|c|c|c|c|}
\hline \multicolumn{3}{|c|}{ Estudo de Caso 1} & \multirow{2}{*}{$\begin{array}{l}\text { Tempo de lotação dos entrevistados em } \\
\text { Canteiros de obras }\end{array}$} & \multicolumn{3}{|c|}{ Estudo de Caso 2} \\
\hline$f$ & $f(\%)$ & Posição & & Posição & $f(\%)$ & $f$ \\
\hline 9 & 12,86 & $5^{\circ}$ & Nenhum & $5^{\circ}$ & 6,56 & 4 \\
\hline 16 & 22,86 & $2^{\circ}$ & Menos de 3 anos & $6^{\circ}$ & 4,92 & 3 \\
\hline 15 & 21,43 & $3^{\circ}$ & De 3 a 5 anos & $3^{\circ}$ & 16,39 & 10 \\
\hline 18 & 25,71 & $1^{\circ}$ & De 6 a 10 anos & $2^{\circ}$ & 18,03 & 11 \\
\hline 2 & 2,86 & $6^{\circ}$ & De 11 a 15 anos & $4^{\circ}$ & 14,75 & 9 \\
\hline 10 & 14,28 & $4^{\circ}$ & 15 anos ou mais & $1^{\circ}$ & 39,35 & 24 \\
\hline 70 & 100,00 & & & & 100,00 & 61 \\
\hline
\end{tabular}

FONTE: Pesquisa realizada pelo autor.

LEGENDA: $f=$ freqüência de respostas. 
Tabela C.4 - Respostas ao Quesito 4 e posição das suas variáveis.

\begin{tabular}{|c|c|c|c|c|c|c|}
\hline \multicolumn{3}{|c|}{ Estudo de Caso 1} & \multirow{2}{*}{$\begin{array}{l}\text { Regimes de execução de } \\
\text { contratos }\end{array}$} & \multicolumn{3}{|c|}{ Estudo de Caso 2} \\
\hline fo & fo $(\%)$ & Posição & & Posição & fo $(\%)$ & fo \\
\hline 4 & 3,84 & $4^{\circ}$ & Empreitada integral & $4^{\circ}$ & 11,77 & 16 \\
\hline 30 & 28,85 & $2^{\circ}$ & Empreitada por preço global & $2^{\circ}$ & 24,27 & 33 \\
\hline 29 & 27,89 & $3^{\circ}$ & Empreitada por preço unitário & 10 & 30,14 & 41 \\
\hline 40 & 38,46 & $1^{\circ}$ & Empreitada por preço unitário e global & $3^{\circ}$ & 22,79 & 31 \\
\hline 1 & 0,96 & $5^{\circ}$ & Administração & $5^{\circ}$ & 8,09 & 11 \\
\hline 0 & - & - & Aliança & $6^{\circ}$ & 2,94 & 4 \\
\hline 104 & 100,00 & & & & 100,00 & 136 \\
\hline
\end{tabular}

FONTE: $\quad$ Pesquisa realizada pelo autor.

LEGENDA: $\quad f O=$ freqüência ajustada de respostas.

OBSERVAÇÃO 1: Os regimes de execução grafados em itálico correspondem às indicações da opção Outros feitas pelos entrevistados.

OBSERVAÇÃO 2: Verificaram-se 3 respostas inválidas ou ausentes no Estudo de Caso 1, e 4 no Estudo de Caso 2.

OBSERVAÇÃO 3: Os totais das colunas ultrapassam o tamanho da amostra, uma vez que os entrevistados podiam dar mais de uma resposta.

Tabela C.5 - Experiência dos entrevistados em múltiplos regimes de execução.

\begin{tabular}{|c|c|c|c|c|c|c|}
\hline \multicolumn{3}{|c|}{ Estudo de Caso 1} & \multirow{2}{*}{$\begin{array}{l}\text { Multiplicidade de regimes de execução de } \\
\text { contratos }\end{array}$} & \multicolumn{3}{|c|}{ Estudo de Caso 2} \\
\hline fo & fo (\%) & Posição & & Posição & fo $(\%)$ & fo \\
\hline 44 & 65,67 & $1^{\circ}$ & Somente 1 regime de execução & $1^{\circ}$ & 33,33 & 19 \\
\hline 11 & 16,42 & $2^{\circ}$ & 2 regimes de execução & $2^{\circ}$ & 31,58 & 18 \\
\hline 10 & 14,93 & $3^{\circ}$ & 3 regimes de execução & $4^{\circ}$ & 10,53 & 6 \\
\hline 2 & 2,98 & $4^{\circ}$ & 4 regimes de execução & $3^{\circ}$ & 12,28 & 7 \\
\hline 0 & - & - & 5 regimes de execução ou mais & $3^{\circ}$ & 12,28 & 7 \\
\hline 67 & 100,00 & & & & 100,00 & 57 \\
\hline
\end{tabular}

FONTE: $\quad$ Pesquisa realizada pelo autor.

LEGENDA: $\quad f O=$ freqüência ajustada de respostas.

OBSERVAÇÃO: Verificaram-se 3 respostas inválidas ou ausentes no Estudo de Caso 1, e 4 no Estudo de Caso 2. 
Tabela C.6 - Matriz das respostas do Quesito 4 no Estudo de Caso 1.

\begin{tabular}{|c|c|c|c|c|c|c|}
\hline Regimes de execução & $\begin{array}{c}f \text { para } 1 \\
\text { regime }\end{array}$ & $\begin{array}{l}f \text { para } 2 \\
\text { regimes }\end{array}$ & $\begin{array}{l}f \text { para } 3 \\
\text { regimes }\end{array}$ & $\begin{array}{c}f \text { para } 4 \\
\text { regimes }\end{array}$ & $\begin{array}{c}f \text { para } 5 \text { ou } \\
\text { mais } \\
\text { regimes }\end{array}$ & $\begin{array}{c}\text { Total por } \\
\text { regime }\end{array}$ \\
\hline Empreitada integral & 1 & 1 & 0 & 2 & 0 & 4 \\
\hline Empreitada por preço global & 7 & 11 & 10 & 2 & 0 & 30 \\
\hline Empreitada por preço unitário & 9 & 8 & 10 & 2 & 0 & 29 \\
\hline Empreitada por preço unitário e global & 27 & 2 & 9 & 2 & 0 & 40 \\
\hline Administração & 0 & 0 & 1 & 0 & 0 & 1 \\
\hline Totais & 44 & 22 & 30 & 8 & 0 & 104 \\
\hline Totais de respostas válidas & 44 & 11 & 10 & 2 & 0 & 67 \\
\hline
\end{tabular}

LEGENDA: $\quad f=$ freqüência de respostas.

OBSERVAÇÃO 1: Os regimes de execução grafados em itálico correspondem às indicações da opção Outros feitas pelos entrevistados.

OBSERVAÇÃO 2: Os "Totais de respostas válidas" são obtidos dividindo-se a célula da linha de "Totais" de cada coluna, pela quantidade de regimes de execução correspondente, indicada no seu respectivo cabeçalho.

Tabela C.7 - Matriz das respostas do Quesito 4 no Estudo de Caso 2.

\begin{tabular}{|c|c|c|c|c|c|c|}
\hline Regimes de execução & $\begin{array}{c}f \text { para } 1 \\
\text { regime }\end{array}$ & $\begin{array}{l}f \text { para } 2 \\
\text { regimes }\end{array}$ & $\begin{array}{l}f \text { para } 3 \\
\text { regimes }\end{array}$ & $\begin{array}{l}f \text { para } 4 \\
\text { regimes }\end{array}$ & $\begin{array}{c}f \text { para } 5 \text { ou } \\
\text { mais } \\
\text { regimes }\end{array}$ & $\begin{array}{l}\text { Total por } \\
\text { regime }\end{array}$ \\
\hline Empreitada integral & 0 & 2 & 0 & 7 & 7 & 16 \\
\hline Empreitada por preço global & 2 & 12 & 6 & 6 & 7 & 33 \\
\hline Empreitada por preço unitário & 8 & 13 & 6 & 7 & 7 & 41 \\
\hline Empreitada por preço unitário e global & 8 & 5 & 4 & 7 & 7 & 31 \\
\hline Administração & 1 & 3 & 2 & 0 & 5 & 11 \\
\hline Aliança & 0 & 1 & 0 & 1 & 2 & 4 \\
\hline Totais de regimes de execução & 19 & 36 & 18 & 28 & 35 & 136 \\
\hline Totais de respostas válidas & 19 & 18 & 6 & 7 & 7 & 57 \\
\hline
\end{tabular}

LEGENDA: $\quad f=$ freqüência de respostas.

OBSERVAÇÃO 1: Os regimes de execução grafados em itálico correspondem às indicações da opção Outros feitas pelos entrevistados.

OBSERVAÇÃO 2: Os "Totais de respostas válidas" são obtidos dividindo-se a célula da linha de "Totais" de cada coluna, pela quantidade de regimes de execução correspondente, indicada no seu respectivo cabeçalho. 
Tabela C.8 - Respostas ao Quesito 5 e posição das suas variáveis.

\begin{tabular}{|c|c|c|c|c|c|c|}
\hline \multicolumn{3}{|c|}{ Estudo de Caso 1} & \multirow{2}{*}{$\begin{array}{l}\text { Tempo de experiência dos entrevistados em } \\
\text { Administração de Contrato }\end{array}$} & \multicolumn{3}{|c|}{ Estudo de Caso 2} \\
\hline$f$ & $f(\%)$ & Posição & & Posição & $f(\%)$ & $f$ \\
\hline 4 & 5,71 & $6^{\circ}$ & Não vivenciou & $2^{\circ}$ & 18,64 & 11 \\
\hline 8 & 11,42 & $4^{\circ}$ & Menos de 1 ano & $8^{\circ}$ & 3,39 & 2 \\
\hline 15 & 21,43 & $2^{\circ}$ & De 1 a 3 anos & $6^{\circ}$ & 10,17 & 6 \\
\hline 13 & 18,58 & $3^{\circ}$ & De 3 a 5 anos & $7^{\circ}$ & 5,10 & 3 \\
\hline 19 & 27,15 & $1^{\circ}$ & De 6 a 10 anos & $1^{\circ}$ & 20,34 & 12 \\
\hline 4 & 5,71 & $7^{\circ}$ & De 11 a 15 anos & $3^{\circ}$ & 18,64 & 11 \\
\hline 1 & 1,43 & $8^{\circ}$ & De 16 a 20 anos & $4^{\circ}$ & 11,86 & 7 \\
\hline 6 & 8,57 & $5^{\circ}$ & 21 anos ou mais & $5^{\circ}$ & 11,86 & 7 \\
\hline 70 & 100,00 & & & & 100,0 & 59 \\
\hline
\end{tabular}

FONTE: $\quad$ Pesquisa realizada pelo autor.

LEGENDA: $\quad f=$ freqüência de respostas.

OBSERVAÇÃO: No Estudo de Caso 2, verificaram-se 2 respostas inválidas ou ausentes neste Quesito.

Tabela C.9 - Respostas ao Quesito 6 do questionário.

\begin{tabular}{|c|c|c|c|c|c|c|c|c|}
\hline \multicolumn{4}{|c|}{ Estudo de Caso 1} & \multirow{2}{*}{$\begin{array}{l}\text { Meios de aprendizagem em } \\
\text { Administração de Contrato }\end{array}$} & \multicolumn{4}{|c|}{ Estudo de Caso 2} \\
\hline$f$ & $f r(\%)$ & fo $(\%)$ & Posição & & Posição & $f$ & $f r(\%)$ & fo $(\%)$ \\
\hline 426 & 20,79 & 21,43 & $2^{\circ}$ & Com base em cursos acadêmicos & $4^{\circ}$ & 311 & 17,00 & 17,46 \\
\hline 239 & 11,66 & 12,02 & $5^{\circ}$ & Com base na intuição & $5^{\circ}$ & 229 & 12,53 & 12,87 \\
\hline 350 & 17,08 & 17,61 & $3^{\circ}$ & Com base na observação do dia-a-dia & $3^{\circ}$ & 319 & 17,44 & 17,91 \\
\hline 308 & 15,03 & 15,49 & $4^{\circ}$ & Com base no exemplo do líder & $2^{\circ}$ & 342 & 18,70 & 19,20 \\
\hline 435 & 21,23 & 21,88 & $1^{\circ}$ & Com base no planejamento & $1^{\circ}$ & 345 & 18,86 & 19,37 \\
\hline 194 & 9,47 & 9,76 & $6^{\circ}$ & Tentando & $6^{\circ}$ & 181 & 9,90 & 10,16 \\
\hline 36 & 1,76 & 1,81 & $7^{\circ}$ & Outros & $7^{\circ}$ & 54 & 2,95 & 3,03 \\
\hline 61 & 2,98 & - & & Inválidos ou ausentes & & 38 & 2,62 & - \\
\hline 2.049 & 100,00 & 100,00 & & & & 1.829 & 100,00 & 100,00 \\
\hline
\end{tabular}

LEGENDA: $\quad f=$ freqüência de respostas. $\quad f r=$ freqüência relativa. $\quad f o=$ freqüência ajustada.

OBSERVAÇÃO 1: No Estudo de Caso 1, a opção Outros recebeu as 6 (seis) indicações transcritas a seguir, acompanhadas das respectivas classificações: Treinamento "in sight" com estudos de casos (em $1^{\circ}$ lugar), Experiência profissional (em $1^{\circ}$ lugar), Estudos de casos e experiência de colegas (em $3^{\circ}$ lugar), Estudo e pesquisa (em $3^{\circ}$ lugar), Rotinas de trabalho (em $4^{\circ}$ lugar) e Recursos específicos (em $6^{\circ}$ lugar). A freqüência ajustada dessa opção distribui-se de maneira uniforme entre as indicações apuradas.

(Continua) 
(Continuação)

OBSERVAÇÃO 2: No Estudo de Caso 2, a opção Outros recebeu as 7 (sete) indicações transcritas a seguir, acompanhadas das respectivas classificações: Educação pelo trabalho (em $1^{\circ}$ lugar), Com base em exemplos e experiências de terceiros (em $2^{\circ}$ lugar), Normas e instruções técnicas e/ou da organização (em $2^{\circ}$ lugar), Apoio de área jurídica (em $3^{\circ}$ lugar), Observação (em $6^{\circ}$ lugar), Pesquisa (em $6^{\circ}$ lugar) e Errando (em $7^{\circ}$ lugar). A freqüência ajustada dessa opção distribui-se de maneira uniforme entre as indicações apuradas.

OBSERVAÇÃO 3: Os totais das colunas ultrapassam o tamanho da amostra, devido à natureza do processo de ponderação, descrito no Capítulo 5.

Tabela C.10 - Respostas ao Quesito 7 do questionário.

\begin{tabular}{|c|c|c|c|c|c|c|}
\hline \multicolumn{3}{|c|}{ Estudo de Caso 1} & \multirow{2}{*}{$\begin{array}{l}\text { Fatores que mais influem no } \\
\text { Gerenciamento de Projetos }\end{array}$} & \multicolumn{3}{|c|}{ Estudo de Caso 2} \\
\hline$f$ & $f r(\%)$ & fo $(\%)$ & & $f$ & $\operatorname{fr}(\%)$ & fo $(\%)$ \\
\hline 851 & 8,18 & 8,22 & (1) Abrangência do escopo & 782 & 8,55 & 8,57 \\
\hline 711 & 6,83 & 6,86 & (2) Acompanhamento e avaliação progressiva & 591 & 6,46 & 6,47 \\
\hline 346 & 3,33 & 3,34 & (3) Aquisição de materiais de construção & 395 & 4,32 & 4,33 \\
\hline 794 & 7,63 & 7,67 & (4) Avaliação estratégica da complexidade & 781 & 8,54 & 8,55 \\
\hline 698 & 6,71 & 6,74 & (5) Caminho crítico da gestão & 646 & 7,06 & 7,08 \\
\hline 378 & 3,63 & 3,65 & (6) Memória técnica da execução & 237 & 2,59 & 2,60 \\
\hline 741 & 7,12 & 7,15 & (7) Designação das pessoas da equipe & 809 & 8,85 & 8,86 \\
\hline 609 & 5,85 & 5,88 & (8) Detalhamento da estimativa & 520 & 5,69 & 5,70 \\
\hline 726 & 6,98 & 7,01 & (9) Estimativa de custo & 628 & 6,87 & 6,88 \\
\hline 429 & 4,12 & 4,14 & (10) Finalização do projeto & 320 & 3,50 & 3,50 \\
\hline 654 & 6,29 & 6,31 & (11) Gestão do custo & 567 & 6,20 & 6,21 \\
\hline 940 & 9,03 & 9,08 & (12) Organização do projeto & 765 & 8,36 & 8,38 \\
\hline 1.077 & 10,35 & 10,40 & (13) Planejamento do projeto & 879 & 9,61 & 9,63 \\
\hline 484 & 4,65 & 4,67 & (14) Produtividade mão de obra de execução & 459 & 5,02 & 5,03 \\
\hline 371 & 3,57 & 3,58 & (15) Produtividade operação de equipamentos & 377 & 4,12 & 4,13 \\
\hline 521 & 5,01 & 5,03 & (16) Software para gerenciamento do projeto & 338 & 3,70 & 3,70 \\
\hline 28 & 0,27 & 0,27 & (17) Outros & 36 & 0,39 & 0,39 \\
\hline 46 & 0,44 & - & Inválidos ou ausentes & 16 & 0,17 & - \\
\hline 10.404 & 100,00 & 100,00 & & 9.146 & 100,00 & 100,00 \\
\hline
\end{tabular}

FONTE: $\quad$ Pesquisa realizada pelo autor.

LEGENDA: $\quad f=$ freqüência de respostas. $\quad f r=$ freqüência relativa. $\quad f o=$ freqüência ajustada.

OBSERVAÇÃO 1: No Estudo de Caso 1, a opção Outros recebeu as 3 (três) indicações transcritas a seguir, acompanhadas das respectivas classificações: Gerenciamento dos riscos (em $4^{\circ}$ lugar), Executar (em $11^{\circ}$ lugar) e Objetivos claros (em $11^{\circ}$ lugar).

(Continua) 
(Conclusão)

OBSERVAÇÃO 2: No Estudo de Caso 2, a opção Outros recebeu as 3 (três) indicações transcritas a seguir, acompanhadas das respectivas classificações: Conhecimento do contrato (em $1^{\circ}$ lugar), Definição de consultorias especializadas (em $7^{\circ}$ lugar) e Partilha de resultados (em $17^{\circ}$ lugar).

OBSERVAÇÃO 3: Os totais das colunas ultrapassam o tamanho da amostra, devido à natureza do processo de ponderação, descrito no Capítulo 5.

Tabela C.11 - Respostas ao Quesito 8 do questionário.

\begin{tabular}{|c|c|c|c|c|c|c|}
\hline \multicolumn{3}{|c|}{ Estudo de Caso 1} & \multirow{2}{*}{$\begin{array}{l}\text { Fatores que mais influem no } \\
\text { Gerenciamento de Projetos }\end{array}$} & \multicolumn{3}{|c|}{ Estudo de Caso 2} \\
\hline$f$ & $\operatorname{fr}(\%)$ & fo (\%) & & $f$ & $\operatorname{fr}(\%)$ & fo $(\%)$ \\
\hline 5.592 & 6,70 & 6,70 & (1) Abrangência do escopo & 5.161 & 6,94 & 6,94 \\
\hline 5.546 & 6,64 & 6,65 & (2) Acompanhamento e avaliação progressiva & 4.864 & 6,54 & 6,54 \\
\hline 4.257 & 5,10 & 5,10 & (3) Aquisição de materiais de construção & 3.993 & 5,37 & 5,37 \\
\hline 5.248 & 6,28 & 6,29 & (4) Avaliação estratégica da complexidade & 5.184 & 6,97 & 6,97 \\
\hline 5.095 & 6,10 & 6,11 & (5) Caminho crítico da gestão & 4.880 & 6,56 & 6,56 \\
\hline 3.848 & 4,61 & 4,61 & (6) Memória técnica da execução & 3.500 & 4,71 & 4,71 \\
\hline 5.592 & 6,70 & 6,70 & (7) Designação das pessoas da equipe & 5.289 & 7,11 & 7,11 \\
\hline 5.115 & 6,13 & 6,13 & (8) Detalhamento da estimativa & 4.329 & 5,82 & 5,82 \\
\hline 5.608 & 6,72 & 6,72 & (9) Estimativa de custo & 4.759 & 6,40 & 6,40 \\
\hline 4.865 & 5,83 & 5,83 & (10) Finalização do projeto & 3.987 & 5,36 & 5,36 \\
\hline 5.337 & 6,39 & 6,40 & (11) Gestão do custo & 4.858 & 6,53 & 6,54 \\
\hline 6.251 & 7,49 & 7,49 & (12) Organização do projeto & 5.127 & 6,89 & 6,90 \\
\hline 6.518 & 7,81 & 7,81 & (13) Planejamento do projeto & 5.496 & 7,39 & 7,39 \\
\hline 4.905 & 5,87 & 5,88 & (14) Produtividade mão de obra de execução & 4.356 & 5,86 & 5,86 \\
\hline 4.563 & 5,46 & 5,47 & (15) Produtividade operação de equipamentos & 4.151 & 5,58 & 5,58 \\
\hline 4.862 & 5,82 & 5,83 & (16) Software para gerenciamento do projeto & 3.911 & 5,26 & 5,26 \\
\hline 249 & 0,30 & 0,30 & (17) Outros & 492 & 0,66 & 0,66 \\
\hline 54 & 0,06 & - & Inválidos ou ausentes & 30 & 0,04 & - \\
\hline 83.505 & 100,00 & 100,00 & & 74.367 & 100,00 & 100,00 \\
\hline
\end{tabular}

FONTE: $\quad$ Pesquisa realizada pelo autor.

LEGENDA: $\quad f=$ freqüência de respostas. $\quad f r=$ freqüência relativa. $\quad f o=$ freqüência ajustada.

OBSERVAÇÃO 1: No Estudo de Caso 1, a opção Outros recebeu as 3 (três) indicações transcritas a seguir, acompanhadas das respectivas classificações: Gerenciamento dos riscos (em $4^{\circ}$ lugar), Executar (em $11^{\circ}$ lugar) e Objetivos claros (em $11^{\circ}$ lugar).

(Continua) 
(Conclusão)

OBSERVAÇÃO 2: No Estudo de Caso 2, a opção Outros recebeu as 3 (três) indicações transcritas a seguir, acompanhadas das respectivas classificações: Conhecimento do contrato (em $1^{\circ}$ lugar), Definição de consultorias especializadas (em $7^{\circ}$ lugar) e Partilha de resultados (em $17^{\circ}$ lugar).

OBSERVAÇÃO 3: Os totais das colunas ultrapassam o tamanho da amostra, devido à natureza do processo de ponderação, descrito no Capítulo 5.

Tabela C.12 - Posição das variáveis dos Quesitos 7 e 8.

\begin{tabular}{|c|c|c|c|c|}
\hline \multicolumn{2}{|c|}{ Estudo de Caso 1} & \multirow{2}{*}{$\begin{array}{l}\text { Fatores que mais influem no } \\
\text { Gerenciamento de Projetos }\end{array}$} & \multicolumn{2}{|c|}{ Estudo de Caso 2} \\
\hline$\Sigma(f o)$ & Posição & & Posição & $\Sigma(f o)$ \\
\hline 6.443 & $3^{\circ}$ & (1) Abrangência do escopo & $4^{\circ}$ & 5.943 \\
\hline 6.257 & $6^{\circ}$ & (2) Acompanhamento e avaliação progressiva & $7^{\circ}$ & 5.455 \\
\hline 4.603 & $15^{\circ}$ & (3) Aquisição de materiais de construção & $13^{\circ}$ & 4.388 \\
\hline 6.042 & $7^{\circ}$ & (4) Avaliação estratégica da complexidade & $3^{\circ}$ & 5.965 \\
\hline 5.793 & $9^{\circ}$ & (5) Caminho crítico da gestão & $6^{\circ}$ & 5.526 \\
\hline 4.226 & $16^{\circ}$ & (6) Memória técnica da execução & $16^{\circ}$ & 3.737 \\
\hline 6.333 & $5^{\circ}$ & (7) Designação das pessoas da equipe & $2^{\circ}$ & 6.098 \\
\hline 5.724 & $10^{\circ}$ & (8) Detalhamento da estimativa & $10^{\circ}$ & 4.849 \\
\hline 6.334 & $4^{\circ}$ & (9) Estimativa de custo & $9^{\circ}$ & 5.387 \\
\hline 5.294 & $11^{\circ}$ & (10) Finalização do projeto & $14^{\circ}$ & 4.307 \\
\hline 5.991 & $8^{\circ}$ & (11) Gestão do custo & $8^{\circ}$ & 5.425 \\
\hline 7.191 & $2^{\circ}$ & (12) Organização do projeto & $5^{\circ}$ & 5.892 \\
\hline 7.595 & 10 & (13) Planejamento do projeto & 10 & 6.375 \\
\hline 5.389 & $12^{\circ}$ & (14) Produtividade da mão de obra de execução & $11^{\circ}$ & 4.815 \\
\hline 4.934 & $14^{\circ}$ & (15) Produtividade na operação de equipamentos & $12^{\circ}$ & 4.528 \\
\hline 5.383 & $13^{\circ}$ & (16) Software para gerenciamento do projeto & $15^{\circ}$ & 4.249 \\
\hline 277 & $17^{\circ}$ & (17) Outros & $17^{\circ}$ & 528 \\
\hline 93.809 & & & & 83.467 \\
\hline
\end{tabular}

FONTE: $\quad$ Pesquisa realizada pelo autor.

LEGENDA: $\quad \Sigma(f o)=$ somatório das freqüências ajustadas das respostas às variáveis dos Quesitos 7 e 8 do questionário.

OBSERVAÇÃO 1: No Estudo de Caso 1 obteve-se a mesma classificação para as variáveis (7), (12), (13), (14) e (17) dos Quesitos 7 e 8, tanto na apuração do Quesito 7 como na do Quesito 8.

OBSERVAÇÃO 2: No Estudo de Caso 2 obteve-se a mesma classificação para as variáveis (5), (6), (7), (12), (13) e (17) dos Quesitos 7 e 8, tanto na apuração do Quesito 7 como na do Quesito 8. 
Tabela C.13 - Respostas ao Quesito 9 do questionário.

\begin{tabular}{|c|c|c|c|c|c|c|}
\hline \multicolumn{3}{|c|}{ Estudo de Caso 1} & \multirow{2}{*}{$\begin{array}{l}\text { Habilidades técnicas do Gerente, que mais } \\
\text { influem no Gerenciamento de Projetos }\end{array}$} & \multicolumn{3}{|c|}{ Estudo de Caso 2} \\
\hline$f$ & $f r(\%)$ & fo $(\%)$ & & $f$ & $f r(\%)$ & fo $(\%)$ \\
\hline 842 & 7,11 & 7,14 & (1) Administração simultânea de múltiplas prioridades & 598 & 5,83 & 5,85 \\
\hline 606 & 5,12 & 5,14 & (2) Ajuste do estilo de liderança ao longo da execução & 450 & 4,39 & 4,40 \\
\hline 840 & 7,10 & 7,13 & (3) Avaliação do empreendimento como um todo & 773 & 7,54 & 7,56 \\
\hline 661 & 5,58 & 5,61 & (4) Conceito das funções do processo de gestão & 481 & 4,69 & 4,71 \\
\hline 673 & 5,69 & 5,71 & (5) Conhecimento das próprias forças e fraquezas & 645 & 6,29 & 6,31 \\
\hline 852 & 7,20 & 7,23 & (6) Delegação & 727 & 7,09 & 7,11 \\
\hline 838 & 7,08 & 7,11 & (7) Desempenho (método de trabalho) do gerente & 469 & 4,57 & 4,59 \\
\hline 697 & 5,89 & 5,91 & (8) Desenvolvimento das pessoas & 553 & 5,39 & 5,41 \\
\hline 371 & 3,13 & 3,15 & (9) Escolha da melhor maneira de orçar & 316 & 3,08 & 3,09 \\
\hline 817 & 6,90 & 6,93 & (10) Estratégia & 750 & 7,31 & 7,34 \\
\hline 930 & 7,86 & 7,89 & (11) Integração da equipe & 760 & 7,41 & 7,44 \\
\hline 1.024 & 8,65 & 8,69 & (12) Liderança & 897 & 8,75 & 8,78 \\
\hline 543 & 4,59 & 4,61 & (13) Necessidades do Cliente & 803 & 7,83 & 7,86 \\
\hline 372 & 3,14 & 3,16 & (14) Procedimentos e políticas & 342 & 3,34 & 3,35 \\
\hline 364 & 3,08 & 3,09 & (15) Reuniões periódicas & 183 & 1,78 & 1,79 \\
\hline 562 & 4,75 & 4,77 & (16) Seleção e mobilização da equipe & 597 & 5,82 & 5,84 \\
\hline 382 & 3,23 & 3,24 & (17) Tática & 338 & 3,30 & 3,31 \\
\hline 413 & 3,49 & 3,50 & (18) Visão da oportunidade & 538 & 5,25 & 5,26 \\
\hline 0 & - & - & (19) Outros & 0 & - & - \\
\hline 50 & 0,42 & - & Inválidos ou ausentes & 34 & 0,33 & - \\
\hline 11.837 & 100,00 & 100,00 & & 10.254 & 100,00 & 100,00 \\
\hline
\end{tabular}

FONTE: $\quad$ Pesquisa realizada pelo autor.

LEGENDA: $\quad f=$ freqüência de respostas. $\quad f r=$ freqüência relativa. $\quad f o$ = freqüência ajustada.

OBSERVAÇÃO: Os totais das colunas ultrapassam o tamanho da amostra, devido à natureza do processo de ponderação, descrito no Capítulo 5. 
Tabela C.14 - Respostas ao Quesito 10 do questionário.

\begin{tabular}{|c|c|c|c|c|c|c|}
\hline \multicolumn{3}{|c|}{ Estudo de Caso 1} & \multirow{2}{*}{$\begin{array}{l}\text { Habilidades técnicas do Gerente, que mais } \\
\text { influem no Gerenciamento de Projetos }\end{array}$} & \multicolumn{3}{|c|}{ Estudo de Caso 2} \\
\hline$f$ & $\operatorname{fr}(\%)$ & fo $(\%)$ & & $f$ & $\operatorname{fr}(\%)$ & fo $(\%)$ \\
\hline 5.651 & 5,80 & 5,81 & (1) Administração simultânea de múltiplas prioridades & 4.672 & 5,47 & 5,47 \\
\hline 5.222 & 5,36 & 5,36 & (2) Ajuste do estilo de liderança ao longo da execução & 4.464 & 5,23 & 5,23 \\
\hline 6.014 & 6,17 & 6,18 & (3) Avaliação do empreendimento como um todo & 5.337 & 6,25 & 6,25 \\
\hline 5.213 & 5,35 & 5,36 & (4) Conceito das funções do processo de gestão & 4.492 & 5,26 & 5,26 \\
\hline 5.445 & 5,59 & 5,59 & (5) Conhecimento das próprias forças e fraquezas & 4.908 & 5,75 & 5,75 \\
\hline 5.894 & 6,05 & 6,05 & (6) Delegação & 5.142 & 6,02 & 6,02 \\
\hline 5.886 & 6,04 & 6,05 & (7) Desempenho (método de trabalho) do gerente & 4.460 & 5,22 & 5,22 \\
\hline 5.683 & 5,83 & 5,84 & (8) Desenvolvimento das pessoas & 4.902 & 5,74 & 5,74 \\
\hline 4.406 & 4,52 & 4,53 & (9) Escolha da melhor maneira de orçar & 3.911 & 4,58 & 4,58 \\
\hline 5.804 & 5,96 & 5,96 & (10) Estratégia & 5.226 & 6,16 & 6,17 \\
\hline 6.184 & 6,35 & 6,35 & (11) Integração da equipe & 5.392 & 6,31 & 6,32 \\
\hline 6.338 & 6,51 & 6,51 & (12) Liderança & 5.613 & 6,57 & 6,57 \\
\hline 5.125 & 5,26 & 5,26 & (13) Necessidades do Cliente & 5.268 & 6,17 & 6,17 \\
\hline 4.628 & 4,75 & 4,75 & (14) Procedimentos e políticas & 4.090 & 4,79 & 4,79 \\
\hline 4.814 & 4,94 & 4,95 & (15) Reuniões periódicas & 3.597 & 4,21 & 4,21 \\
\hline 5.353 & 5,50 & 5,50 & (16) Seleção e mobilização da equipe & 4.848 & 5,68 & 5,68 \\
\hline 4.646 & 4,77 & 4,77 & (17) Tática & 4.243 & 4,97 & 4,97 \\
\hline 5.036 & 5,17 & 5,17 & (18) Visão da oportunidade & 4.776 & 5,59 & 5,59 \\
\hline 0 & - & - & (19) Outros & 0 & - & - \\
\hline 59 & 0,06 & - & Inválidos ou ausentes & 39 & 0,05 & - \\
\hline 97.401 & 100,00 & 100,00 & & 85.420 & 100,00 & 100,00 \\
\hline
\end{tabular}

FONTE: $\quad$ Pesquisa realizada pelo autor.

LEGENDA: $\quad f=$ freqüência de respostas. $\quad f r=$ freqüência relativa. $\quad f o=$ freqüência ajustada.

OBSERVAÇÃO: Os totais das colunas ultrapassam o tamanho da amostra, devido à natureza do processo de ponderação, descrito no Capítulo 5. 
Tabela C.15 - Posição das variáveis dos Quesitos 9 e 10.

\begin{tabular}{|c|c|c|c|c|}
\hline \multicolumn{2}{|c|}{ Estudo de Caso 1} & \multirow{2}{*}{$\begin{array}{l}\text { Habilidades técnicas do Gerente, que mais influem no } \\
\text { Gerenciamento de Projetos }\end{array}$} & \multicolumn{2}{|c|}{ Estudo de Caso 2} \\
\hline$\Sigma(f o)$ & Posição & & Posição & $\Sigma(f o)$ \\
\hline 6.493 & $7^{\circ}$ & (1) Administração simultânea de múltiplas prioridades & $11^{\circ}$ & 5.270 \\
\hline 5.828 & $12^{\circ}$ & (2) Ajuste do estilo de liderança ao longo da execução & $14^{\circ}$ & 4.914 \\
\hline 6.854 & $3^{\circ}$ & (3) Avaliação do empreendimento como um todo & $3^{\circ}$ & 6.110 \\
\hline 5.874 & $11^{\circ}$ & (4) Conceito das funções do processo de gestão & $12^{\circ}$ & 4.973 \\
\hline 6.118 & $9^{\circ}$ & (5) Conhecimento das próprias forças e fraquezas & $7^{\circ}$ & 5.553 \\
\hline 6.746 & $4^{\circ}$ & (6) Delegação & $6^{\circ}$ & 5.869 \\
\hline 6.724 & $5^{\circ}$ & (7) Desempenho (método de trabalho) do gerente & $13^{\circ}$ & 4.929 \\
\hline 6.380 & $8^{\circ}$ & (8) Desenvolvimento das pessoas & $8^{\circ}$ & 5.455 \\
\hline 4.777 & $18^{\circ}$ & (9) Escolha da melhor maneira de orçar & $17^{\circ}$ & 4.227 \\
\hline 6.621 & $6^{\circ}$ & (10) Estratégia & $5^{\circ}$ & 6.016 \\
\hline 7.114 & $2^{\circ}$ & (11) Integração da equipe & $2^{\circ}$ & 6.152 \\
\hline 7.362 & $1^{\circ}$ & (12) Liderança & $1^{\circ}$ & 6.510 \\
\hline 5.668 & $13^{\circ}$ & (13) Necessidades do Cliente & $4^{\circ}$ & 6.071 \\
\hline 5.000 & $17^{\circ}$ & (14) Procedimentos e políticas & $16^{\circ}$ & 4.432 \\
\hline 5.178 & $15^{\circ}$ & (15) Reuniões periódicas & $18^{\circ}$ & 3.780 \\
\hline 5.915 & $10^{\circ}$ & (16) Seleção e mobilização da equipe & $9^{\circ}$ & 5.445 \\
\hline 5.028 & $16^{\circ}$ & (17) Tática & $15^{\circ}$ & 4.581 \\
\hline 5.449 & $14^{\circ}$ & (18) Visão da oportunidade & $10^{\circ}$ & 5.314 \\
\hline 0 & - & (19) Outros & - & 0 \\
\hline 109.129 & & & & 95.601 \\
\hline
\end{tabular}

FONTE: $\quad$ Pesquisa realizada pelo autor.

LEGENDA: $\quad \Sigma(f o)=$ somatório das freqüências ajustadas das respostas às variáveis dos Quesitos 9 e 10 do questionário.

OBSERVAÇÃO 1: No Estudo de Caso 1 obteve-se a mesma classificação para as variáveis (5), (8), (11), (12), (14), (18) e (19) dos Quesitos 9 e 10, tanto na apuração do Quesito 9 como na do Quesito 10.

OBSERVAÇÃO 2: No Estudo de Caso 2 obteve-se a mesma classificação para as variáveis (3), (5), (6), (7), (9), (10), (12), (15), (16) e (19) dos Quesitos 9 e 10, tanto na apuração do Quesito 9 como na do Quesito 10. 
Tabela C.16 - Respostas ao Quesito 11 do questionário.

\begin{tabular}{|c|c|c|c|c|c|c|}
\hline \multicolumn{3}{|c|}{ Estudo de Caso 1} & \multirow{2}{*}{$\begin{array}{l}\text { Habilidades pessoais do Gerente, que mais } \\
\text { influem no Gerenciamento de Projetos }\end{array}$} & \multicolumn{3}{|c|}{ Estudo de Caso 2} \\
\hline$f$ & $\operatorname{fr}(\%)$ & fo (\%) & & $f$ & $\operatorname{fr}(\%)$ & fo $(\%)$ \\
\hline 442 & 6,19 & 6,19 & (1) Comunicação escrita & 305 & 4,96 & 4,97 \\
\hline 602 & 8,43 & 8,43 & (2) Comunicação verbal & 501 & 8,15 & 8,16 \\
\hline 582 & 8,15 & 8,15 & (3) Criatividade & 591 & 9,61 & 9,63 \\
\hline 613 & 8,58 & 8,58 & (4) Estimulador/ Educador de pessoas & 642 & 10,44 & 10,46 \\
\hline 579 & 8,10 & 8,10 & (5) Flexibilidade & 508 & 8,26 & 8,28 \\
\hline 501 & 7,01 & 7,01 & (6) Influenciador & 599 & 9,74 & 9,76 \\
\hline 652 & 9,13 & 9,13 & (7) Negociação & 586 & 9,53 & 9,55 \\
\hline 752 & 10,52 & 10,52 & (8) Objetividade e clareza em apresentar/oferecer & 592 & 9,63 & 9,65 \\
\hline 781 & 10,93 & 10,93 & (9) Pensamento crítico/ Tomada de decisão & 626 & 10,18 & 10,20 \\
\hline 555 & 7,77 & 7,77 & (10) Sociabilidade & 397 & 6,46 & 6,47 \\
\hline 596 & 8,34 & 8,34 & (11) Solução de conflitos & 458 & 7,45 & 7,46 \\
\hline 458 & 6,41 & 6,41 & (12) Solução de problemas técnicos & 282 & 4,59 & 4,60 \\
\hline 32 & 0,45 & 0,45 & (13) Outros & 49 & 0,80 & 0,80 \\
\hline 0 & - & - & Inválidos ou ausentes & 12 & 0,20 & - \\
\hline 7.145 & 100,00 & 100,00 & & 6.148 & 100,00 & 100,00 \\
\hline
\end{tabular}

FONTE: $\quad$ Pesquisa realizada pelo autor.

LEGENDA: $\quad f=$ freqüência de respostas. $\quad f r=$ freqüência relativa. $\quad f o=$ freqüência ajustada.

OBSERVAÇÃO 1: No Estudo de Caso 1, a opção Outros recebeu as 3 (três) indicações transcritas a seguir, acompanhadas das respectivas classificações: Consciência de estar lidando com dinheiro público (em $1^{\circ}$ lugar), Honestidade (em $2^{\circ}$ lugar) e Organização (em $10^{\circ}$ lugar).

OBSERVAÇÃO 2: No Estudo de Caso 2, a opção Outros recebeu as 2 (duas) indicações transcritas a seguir, acompanhadas das respectivas classificações: Liderança (em $1{ }^{\circ}$ lugar), e Capacidade de agregar pessoas (líderes, liderados, clientes, usuários, etc) em torno do objetivo comum (em 8 o lugar).

OBSERVAÇÃO 3: Os totais das colunas ultrapassam o tamanho da amostra, devido à natureza do processo de ponderação, descrito no Capítulo 5.

Tabela C.17 - Respostas ao Quesito 12 do questionário.

\begin{tabular}{|c|c|c|c|c|c|c|}
\hline \multicolumn{3}{|c|}{ Estudo de Caso 1} & \multirow{2}{*}{$\begin{array}{l}\text { Habilidades pessoais do Gerente, que mais } \\
\text { Influem no Gerenciamento de Projetos }\end{array}$} & \multicolumn{3}{|c|}{ Estudo de Caso 2} \\
\hline$f$ & $f r(\%)$ & fo $(\%)$ & & $f$ & $f r(\%)$ & fo (\%) \\
\hline 5.549 & 7,80 & 7,80 & (1) Comunicação escrita & 4.433 & 7,17 & 7,17 \\
\hline 6.015 & 8,46 & 8,46 & (2) Comunicação verbal & 5.052 & 8,17 & 8,17 \\
\hline 5.920 & 8,32 & 8,32 & (3) Criatividade & 5.311 & 8,59 & 8,59 \\
\hline
\end{tabular}

(Continua) 
(Conclusão)

\begin{tabular}{|c|c|c|c|c|c|c|}
\hline \multicolumn{3}{|c|}{ Estudo de Caso 1} & \multirow{2}{*}{$\begin{array}{l}\text { Habilidades pessoais do Gerente, que mais } \\
\text { Influem no Gerenciamento de Projetos }\end{array}$} & \multicolumn{3}{|c|}{ Estudo de Caso 2} \\
\hline$f$ & $f r(\%)$ & fo $(\%)$ & & $f$ & $\operatorname{fr}(\%)$ & fo $(\%)$ \\
\hline 5.676 & 7,98 & 7,98 & (4) Estimulador/ Educador de pessoas & 5.488 & 8,88 & 8,88 \\
\hline 5.843 & 8,21 & 8,21 & (5) Flexibilidade & 5.261 & 8,51 & 8,51 \\
\hline 5.101 & 7,17 & 7,17 & (6) Influenciador & 5.293 & 8,56 & 8,56 \\
\hline 6.101 & 8,58 & 8,58 & (7) Negociação & 5.408 & 8,75 & 8,75 \\
\hline 6.442 & 9,06 & 9,06 & (8) Objetividade e clareza apresentar/oferecer & 5.353 & 8,66 & 8,66 \\
\hline 6.521 & 9,17 & 9,17 & (9) Pensamento crítico/ Tomada de decisão & 5.520 & 8,93 & 8,93 \\
\hline 5.776 & 8,12 & 8,12 & (10) Sociabilidade & 4.705 & 7,61 & 7,61 \\
\hline 6.142 & 8,63 & 8,63 & (11) Solução de conflitos & 5.062 & 8,19 & 8,19 \\
\hline 5.781 & 8,13 & 8,13 & (12) Solução de problemas técnicos & 4.381 & 7,09 & 7,09 \\
\hline 270 & 0,38 & 0,38 & (13) Outros & 544 & 0,88 & 0,88 \\
\hline 4 & 0,01 & - & Inválidos ou ausentes & 13 & 0,02 & - \\
\hline 71.141 & 100,00 & 100,00 & & 61.824 & 100,00 & 100,00 \\
\hline
\end{tabular}

FONTE: $\quad$ Pesquisa realizada pelo autor.

LEGENDA: $\quad f=$ freqüência de respostas. $\quad f r=$ freqüência relativa. $\quad f o=$ freqüência ajustada.

OBSERVAÇÃO 1: No Estudo de Caso 1, a opção Outros recebeu as 3 (três) indicações transcritas a seguir, acompanhadas das respectivas classificações: Consciência de estar lidando com dinheiro público (em $1^{\circ}$ lugar), Honestidade (em $2^{\circ}$ lugar) e Organização (em $10^{\circ}$ lugar).

OBSERVAÇÃO 2: No Estudo de Caso 2, a opção Outros recebeu as 2 (duas) indicações transcritas a seguir, acompanhadas das respectivas classificações: Liderança (em $1^{\circ}$ lugar), e Capacidade de agregar pessoas (líderes, liderados, clientes, usuários, etc) em torno do objetivo comum (em 8 lugar).

OBSERVAÇÃO 3: Os totais das colunas ultrapassam o tamanho da amostra, devido à natureza do processo de ponderação, descrito no Capítulo 5.

Tabela C.18 - Posição das variáveis dos Quesitos 11 e 12.

\begin{tabular}{|c|c|c|c|c|}
\hline \multicolumn{2}{|c|}{ Estudo de Caso 1} & \multirow{2}{*}{$\begin{array}{l}\text { Habilidades pessoais do Gerente, que mais influem no } \\
\text { Gerenciamento de Projetos }\end{array}$} & \multicolumn{2}{|c|}{ Estudo de Caso 2} \\
\hline$\Sigma(f o)$ & Posição & & Posição & $\Sigma(f o)$ \\
\hline 5.991 & $11^{\circ}$ & (1) Comunicação escrita & $11^{\circ}$ & 4.738 \\
\hline 6.617 & $5^{\circ}$ & (2) Comunicação verbal & $8^{\circ}$ & 5.553 \\
\hline 6.502 & $6^{\circ}$ & (3) Criatividade & $5^{\circ}$ & 5.902 \\
\hline 6.289 & $9^{\circ}$ & (4) Estimulador/ Educador de pessoas & $2^{\circ}$ & 6.130 \\
\hline 6.422 & $7^{\circ}$ & (5) Flexibilidade & $7^{\circ}$ & 5.769 \\
\hline 5.602 & $12^{\circ}$ & (6) Influenciador & $6^{\circ}$ & 5.892 \\
\hline
\end{tabular}

(Continua) 
(Conclusão)

\begin{tabular}{|c|c|c|c|c|}
\hline \multicolumn{2}{|c|}{ Estudo de Caso 1} & \multirow{2}{*}{$\begin{array}{l}\text { Habilidades pessoais do Gerente, que mais influem no } \\
\text { Gerenciamento de Projetos }\end{array}$} & \multicolumn{2}{|c|}{ Estudo de Caso 2} \\
\hline$\Sigma(f o)$ & Posição & & Posição & $\Sigma(f o)$ \\
\hline 6.753 & $3^{\circ}$ & (7) Negociação & $3^{\circ}$ & 5.994 \\
\hline 7.194 & $2^{\circ}$ & (8) Objetividade e clareza apresentar/oferecer & $4^{\circ}$ & 5.945 \\
\hline 7.302 & $1^{\circ}$ & (9) Pensamento crítico/ Tomada de decisão & $1^{\circ}$ & 6.146 \\
\hline 6.331 & $8^{\circ}$ & (10) Sociabilidade & $10^{\circ}$ & 5.102 \\
\hline 6.738 & $4^{\circ}$ & (11) Solução de conflitos & $9^{\circ}$ & 5.520 \\
\hline 6.239 & $10^{\circ}$ & (12) Solução de problemas técnicos & $12^{\circ}$ & 4.663 \\
\hline 302 & $13^{\circ}$ & (13) Outros & $13^{\circ}$ & 593 \\
\hline 78.282 & & & & 67.947 \\
\hline
\end{tabular}

FONTE: $\quad$ Pesquisa realizada pelo autor.

LEGENDA: $\quad \Sigma(f o)=$ somatório das freqüências ajustadas das respostas às variáveis dos Quesitos 11 e 12 do questionário.

OBSERVAÇÃO 1: No Estudo de Caso 1 obteve-se a mesma classificação para as variáveis (2), (8), (9), (10) e (13) dos Quesitos 11 e 12, tanto na apuração do Quesito 11 como na do Quesito 12.

OBSERVAÇÃO 2: No Estudo de Caso 2 obteve-se a mesma classificação para as variáveis (1), (3), (5), (8), (10), (12) e (13) dos Quesitos 11 e 12, tanto na apuração do Quesito 11 como na do Quesito 12.

Tabela C.19 - Respostas ao Quesito 13 do questionário.

\begin{tabular}{|c|c|c|c|c|c|c|}
\hline \multicolumn{3}{|c|}{ Estudo de Caso 1} & \multirow{2}{*}{$\begin{array}{l}\text { Requisitos que mais influem na prática da } \\
\text { Administração de Contrato }\end{array}$} & \multicolumn{3}{|c|}{ Estudo de Caso 2} \\
\hline$f$ & $f r(\%)$ & fo $(\%)$ & & $f$ & $f r(\%)$ & fo $(\%)$ \\
\hline 528 & 7,20 & 7,21 & (1) Apoio jurídico & 331 & 5,17 & 5,17 \\
\hline 551 & 7,51 & 7,53 & (2) Competência na negociação & 552 & 8,62 & 8,62 \\
\hline 689 & 9,40 & 9,41 & (3) Compreensão da base legal & 495 & 7,73 & 7,73 \\
\hline 678 & 9,25 & 9,26 & (4) Compreensão da base técnica & 459 & 7,17 & 7,17 \\
\hline 482 & 6,57 & 6,58 & (5) Conhecimento sobre o Cliente & 675 & 10,54 & 10,54 \\
\hline 537 & 7,32 & 7,33 & (6) Coordenação de interfaces & 400 & 6,25 & 6,25 \\
\hline 473 & 6,45 & 6,46 & (7) Documentação e arquivo & 275 & 4,29 & 4,29 \\
\hline 837 & 11,41 & 11,43 & (8) Domínio do escopo do contrato & 739 & 11,54 & 11,54 \\
\hline 678 & 9,25 & 9,26 & (9) Equipe qualificada & 540 & 8,43 & 8,43 \\
\hline 472 & 6,44 & 6,45 & (10) Integração de atividades multifuncionais & 299 & 4,67 & 4,67 \\
\hline 494 & 6,74 & 6,75 & (11) Liderança & 513 & 8,01 & 8,01 \\
\hline 393 & 5,36 & 5,37 & (12) Orçamento conseqüência planejamento & 367 & 5,73 & 5,73 \\
\hline
\end{tabular}

(Continua) 
(Conclusão)

\begin{tabular}{|c|c|c|c|c|c|c|}
\hline \multicolumn{3}{|c|}{ Estudo de Caso 1} & \multirow{2}{*}{$\begin{array}{l}\text { Requisitos que mais influem na prática da } \\
\text { Administração de Contrato }\end{array}$} & \multicolumn{3}{|c|}{ Estudo de Caso 2} \\
\hline$f$ & $\operatorname{fr}(\%)$ & fo $(\%)$ & & $f$ & $\operatorname{fr}(\%)$ & fo $(\%)$ \\
\hline 148 & 2,02 & 2,02 & (13) Postura ganha-ganha & 374 & 5,84 & 5,84 \\
\hline 362 & 4,94 & 4,94 & (14) Registro de fatos & 386 & 6,03 & 6,03 \\
\hline 0 & - & - & (15) Outros & 0 & - & - \\
\hline 11 & 0,15 & - & Inválidos ou ausentes & 0 & - & - \\
\hline 7.333 & 100,00 & 100,00 & & 6.405 & 100,00 & 100,00 \\
\hline
\end{tabular}

FONTE: $\quad$ Pesquisa realizada pelo autor.

LEGENDA: $\quad f=$ freqüência de respostas. $\quad f r=$ freqüência relativa. $\quad f o=$ freqüência ajustada.

OBSERVAÇÃO: Os totais das colunas ultrapassam o tamanho da amostra, devido à natureza do processo de ponderação, descrito no Capítulo 5.

Tabela C.20 - Respostas ao Quesito 14 do questionário.

\begin{tabular}{|c|c|c|c|c|c|c|}
\hline \multicolumn{3}{|c|}{ Estudo de Caso 1} & \multirow{2}{*}{$\begin{array}{l}\text { Requisitos que mais influem na prática da } \\
\text { Administração de Contrato }\end{array}$} & \multicolumn{3}{|c|}{ Estudo de Caso 2} \\
\hline$f$ & $f r(\%)$ & fo $(\%)$ & & $f$ & $f r(\%)$ & fo $(\%)$ \\
\hline 5.838 & 7,36 & 7,36 & (1) Apoio jurídico & 4.955 & 6,91 & 6,91 \\
\hline 5.890 & 7,43 & 7,43 & (2) Competência na negociação & 5.487 & 7,65 & 7,65 \\
\hline 6.060 & 7,64 & 7,64 & (3) Compreensão da base legal & 5.266 & 7,34 & 7,34 \\
\hline 6.262 & 7,90 & 7,90 & (4) Compreensão da base técnica & 5.166 & 7,20 & 7,20 \\
\hline 5.458 & 6,88 & 6,88 & (5) Conhecimento sobre o Cliente & 5.607 & 7,82 & 7,82 \\
\hline 5.715 & 7,21 & 7,21 & (6) Coordenação de interfaces & 4.888 & 6,81 & 6,81 \\
\hline 5.791 & 7,30 & 7,30 & (7) Documentação e arquivo & 4.649 & 6,48 & 6,48 \\
\hline 6.640 & 8,37 & 8,37 & (8) Domínio do escopo do contrato & 5.760 & 8,03 & 8,03 \\
\hline 6.198 & 7,82 & 7,82 & (9) Equipe qualificada & 5.348 & 7,45 & 7,46 \\
\hline 5.550 & 7,00 & 7,00 & (10) Integração de atividades multifuncionais & 4.613 & 6,43 & 6,43 \\
\hline 5.523 & 6,96 & 6,97 & (11) Liderança & 5.389 & 7,51 & 7,51 \\
\hline 5.522 & 6,96 & 6,96 & (12) Orçamento conseqüência planejamento & 4.960 & 6,91 & 6,91 \\
\hline 3.559 & 4,49 & 4,49 & (13) Postura ganha-ganha & 4.559 & 6,35 & 6,36 \\
\hline 5.287 & 6,67 & 6,67 & (14) Registro de fatos & 5.090 & 7,09 & 7,10 \\
\hline 0 & - & - & (15) Outros & 0 & - & - \\
\hline
\end{tabular}

(Continua) 
(Conclusão)

\begin{tabular}{|c|c|c|c|c|c|c|}
\hline \multicolumn{3}{|c|}{ Estudo de Caso 1} & \multirow{2}{*}{$\begin{array}{l}\text { Requisitos que mais influem na prática da } \\
\text { Administração de Contrato }\end{array}$} & \multicolumn{3}{|c|}{ Estudo de Caso 2} \\
\hline$f$ & $f r(\%)$ & fo $(\%)$ & & $f$ & $\operatorname{fr}(\%)$ & fo $(\%)$ \\
\hline 13 & 0,02 & - & Inválidos ou ausentes & 4 & 0,01 & - \\
\hline 79.306 & 100,00 & 100,00 & & 71.741 & 100,00 & 100,00 \\
\hline
\end{tabular}

FONTE: $\quad$ Pesquisa realizada pelo autor.

LEGENDA: $\quad f=$ freqüência de respostas. $\quad f r=$ freqüência relativa. $\quad f o=$ freqüência ajustada.

OBSERVAÇÃO: Os totais das colunas ultrapassam o tamanho da amostra, devido à natureza do processo de ponderação, descrito no Capítulo 5.

Tabela C.21 - Posição das variáveis dos Quesitos 13 e 14.

\begin{tabular}{|c|c|c|c|c|}
\hline \multicolumn{2}{|c|}{ Estudo de Caso 1} & \multirow{2}{*}{$\begin{array}{l}\text { Requisitos que mais influem na prática da } \\
\text { Administração de Contrato }\end{array}$} & \multicolumn{2}{|c|}{ Estudo de Caso 2} \\
\hline$\Sigma(f o)$ & Posição & & Posição & $\Sigma(f o)$ \\
\hline 6.366 & $6^{\circ}$ & (1) Apoio jurídico & $11^{\circ}$ & 5.286 \\
\hline 6.441 & $5^{\circ}$ & (2) Competência na negociação & $3^{\circ}$ & 6.039 \\
\hline 6.749 & $4^{\circ}$ & (3) Compreensão da base legal & $6^{\circ}$ & 5.761 \\
\hline 6.940 & $2^{\circ}$ & (4) Compreensão da base técnica & $7^{\circ}$ & 5.625 \\
\hline 5.940 & $11^{\circ}$ & (5) Conhecimento sobre o Cliente & $2^{\circ}$ & 6.282 \\
\hline 6.252 & $8^{\circ}$ & (6) Coordenação de interfaces & $10^{\circ}$ & 5.288 \\
\hline 6.264 & $7^{\circ}$ & (7) Documentação e arquivo & $13^{\circ}$ & 4.924 \\
\hline 7.477 & $1^{\circ}$ & (8) Domínio do escopo do contrato & $1^{\circ}$ & 6.499 \\
\hline 6.876 & $3^{\circ}$ & (9) Equipe qualificada & $5^{\circ}$ & 5.888 \\
\hline 6.022 & $9^{\circ}$ & (10) Integração de atividades multifuncionais & $14^{\circ}$ & 4.912 \\
\hline 6.017 & $10^{\circ}$ & (11) Liderança & $4^{\circ}$ & 5.902 \\
\hline 5.915 & $12^{\circ}$ & (12) Orçamento conseqüência planejamento & $9^{\circ}$ & 5.327 \\
\hline 3.707 & $14^{\circ}$ & (13) Postura ganha-ganha & $12^{\circ}$ & 4.933 \\
\hline 5.649 & $13^{\circ}$ & (14) Registro de fatos & $8^{\circ}$ & 5.476 \\
\hline 0 & - & (15) Outros & - & 0 \\
\hline 86.615 & & & & 78.142 \\
\hline
\end{tabular}

FONTE: $\quad$ Pesquisa realizada pelo autor.

LEGENDA: $\quad \Sigma(f o)=$ somatório das freqüências ajustadas das respostas às variáveis dos Quesitos 13 e 14 do questionário.

OBSERVAÇÃO 1: No Estudo de Caso 1 obteve-se a mesma classificação para as variáveis (2), (8), (13), (14) e (15) dos Quesitos 13 e 14 , tanto na apuração do Quesito 13 como na do Quesito 14 do questionário.

OBSERVAÇÃO 2: No Estudo de Caso 2 obteve-se a mesma classificação para as variáveis (2), (3), (4), (5), (8), (10) e (15) dos Quesitos 13 e 14, tanto na apuração do Quesito 13 como na do Quesito 14 do questionário. 
Tabela C.22 - Respostas ao Quesito 15 do questionário.

\begin{tabular}{|c|c|c|c|c|c|c|}
\hline \multicolumn{3}{|c|}{ Estudo de Caso 1} & \multirow{2}{*}{$\begin{array}{l}\text { Fatores que afetam o atendimento de } \\
\text { reivindicação contratual apresentada }\end{array}$} & \multicolumn{3}{|c|}{ Estudo de Caso 2} \\
\hline$f$ & $\operatorname{fr}(\%)$ & fo $(\%)$ & & $f$ & $\operatorname{fr}(\%)$ & fo $(\%)$ \\
\hline 285 & 4,10 & 4,13 & (1) Ambiente no canteiro de obra & 399 & 6,39 & 6,39 \\
\hline 580 & 8,35 & 8,39 & (2) Clareza do texto & 470 & 7,53 & 7,53 \\
\hline 649 & 9,34 & 9,39 & (3) Documentação de suporte & 569 & 9,11 & 9,11 \\
\hline 643 & 9,26 & 9,31 & (4) Domínio do projeto pelo Gerente da obra & 588 & 9,42 & 9,42 \\
\hline 649 & 9,34 & 9,39 & (5) Domínio do projeto pela equipe do Gerente da obra & 582 & 9,32 & 9,32 \\
\hline 599 & 8,62 & 8,67 & (6) Existência de registro dos fatos ocorridos & 625 & 10,01 & 10,01 \\
\hline 752 & 10,83 & 10,88 & (7) Fundamentação legal da reivindicação & 632 & 10,12 & 10,12 \\
\hline 723 & 10,41 & 10,46 & (8) Fundamentação técnica da reivindicação & 660 & 10,57 & 10,57 \\
\hline 464 & 6,68 & 6,72 & (9) Momento do projeto & 457 & 7,32 & 7,32 \\
\hline 530 & 7,63 & 7,67 & (10) Pontualidade no cumprimento do cronograma físico & 395 & 6,33 & 6,33 \\
\hline 490 & 7,05 & 7,09 & (11) Procedimento de decisão da outra parte & 388 & 6,21 & 6,21 \\
\hline 528 & 7,60 & 7,64 & (12) Qualidade da execução do projeto & 413 & 6,61 & 6,61 \\
\hline 17 & 0,24 & 0,25 & (13) Outros & 66 & 1,06 & 1,06 \\
\hline 37 & 0,53 & - & Inválidos ou ausentes & 0 & - & - \\
\hline 6.946 & 100,00 & 100,00 & & 6.244 & 100,00 & 100,00 \\
\hline
\end{tabular}

FONTE: $\quad$ Pesquisa realizada pelo autor.

LEGENDA: $\quad f=$ freqüência de respostas. $\quad f r=$ freqüência relativa. $\quad f o=$ freqüência ajustada.

OBSERVAÇÃO 1: No Estudo de Caso 1, a opção Outros recebeu as 2 (duas) indicações transcritas a seguir, acompanhadas das respectivas classificações: Qualidade do projeto (pranchas e especificações (em $2^{\circ}$ lugar), e Incoerência da reivindicação (em $11^{\circ}$ lugar).

OBSERVAÇÃO 2: No Estudo de Caso 2, a opção Outros recebeu as 4 (quatro) indicações transcritas a seguir, acompanhadas das respectivas classificações: Conhecimento do Cliente (em $2^{\circ}$ lugar), Processo de negociação (em $2^{\circ}$ lugar), Obter autorização do Cliente a cada fato relevante e não esperar o fim do projeto (em $6^{\circ}$ lugar), e Capacidade financeira do Cliente (em $13^{\circ}$ lugar).

OBSERVAÇÃO 3: Os totais das colunas ultrapassam o tamanho da amostra, devido à natureza do processo de ponderação, descrito no Capítulo 5. 
Tabela C.23 - Respostas ao Quesito 16 do questionário.

\begin{tabular}{|c|c|c|c|c|c|c|}
\hline \multicolumn{3}{|c|}{ Estudo de Caso 1} & \multirow{2}{*}{$\begin{array}{l}\text { Fatores que afetam o atendimento de } \\
\text { reivindicação contratual apresentada }\end{array}$} & \multicolumn{3}{|c|}{ Estudo de Caso 2} \\
\hline$f$ & $f r(\%)$ & fo $(\%)$ & & $f$ & $f r(\%)$ & fo $(\%)$ \\
\hline 3.740 & 5,72 & 5,72 & (1) Ambiente no canteiro de obra & 4.644 & 7,39 & 7,39 \\
\hline 5.437 & 8,31 & 8,32 & (2) Clareza do texto & 5.067 & 8,07 & 8,07 \\
\hline 5.882 & 8,99 & 9,00 & (3) Documentação de suporte & 5.438 & 8,66 & 8,66 \\
\hline 5.749 & 8,79 & 8,80 & (4) Domínio do projeto pelo Gerente da obra & 5.397 & 8,59 & 8,59 \\
\hline 5.798 & 8,87 & 8,87 & (5) Domínio do projeto pela equipe do Gerente da obra & 5.349 & 8,51 & 8,51 \\
\hline 5.605 & 8,57 & 8,58 & (6) Existência de registro dos fatos ocorridos & 5.607 & 8,92 & 8,92 \\
\hline 6.181 & 9,45 & 9,46 & (7) Fundamentação legal da reivindicação & 5.619 & 8,94 & 8,94 \\
\hline 6.205 & 9,49 & 9,49 & (8) Fundamentação técnica da reivindicação & 5.666 & 9,02 & 9,02 \\
\hline 4.685 & 7,16 & 7,17 & (9) Momento do projeto & 5.041 & 8,02 & 8,02 \\
\hline 5.321 & 8,14 & 8,14 & (10) Pontualidade no cumprimento do cronograma físico & 4.681 & 7,45 & 7,45 \\
\hline 5.310 & 8,12 & 8,12 & (11) Procedimento de decisão da outra parte & 4.865 & 7,74 & 7,74 \\
\hline 5.261 & 8,05 & 8,05 & (12) Qualidade da execução do projeto & 4.872 & 7,75 & 7,75 \\
\hline 180 & 0,28 & 0,28 & (13) Outros & 578 & 0,92 & 0,92 \\
\hline 39 & 0,06 & - & Inválidos ou ausentes & 3 & 0,00 & - \\
\hline 65.393 & 100,00 & 100,00 & & 62.827 & 100,00 & 100,00 \\
\hline
\end{tabular}

FONTE: $\quad$ Pesquisa realizada pelo autor.

LEGENDA: $\quad f=$ freqüência de respostas. $\quad f r=$ freqüência relativa. $\quad f o=$ freqüência ajustada.

OBSERVAÇÃO 1: No Estudo de Caso 1, a opção Outros recebeu as 2 (duas) indicações transcritas a seguir, acompanhadas das respectivas classificações: Qualidade do projeto (pranchas e especificações (em $2^{\circ}$ lugar), e Incoerência da reivindicação (em $11^{\circ}$ lugar).

OBSERVAÇÃO 2: No Estudo de Caso 2, a opção Outros recebeu as 4 (quatro) indicações transcritas a seguir, acompanhadas das respectivas classificações: Conhecimento do Cliente (em $2^{\circ}$ lugar), Processo de negociação (em $2^{\circ}$ lugar), Obter autorização do Cliente a cada fato relevante e não esperar o fim do projeto (em 6 o lugar), e Capacidade financeira do Cliente (em $13^{\circ}$ lugar).

OBSERVAÇÃO 3: Os totais das colunas ultrapassam o tamanho da amostra, devido à natureza do processo de ponderação, descrito no Capítulo 5. 
Tabela C.24 - Posição das variáveis dos Quesitos 15 e 16.

\begin{tabular}{|c|c|c|c|c|}
\hline \multicolumn{2}{|c|}{ Estudo de Caso 1} & \multirow{2}{*}{$\begin{array}{l}\text { Fatores que afetam o atendimento de reivindicação } \\
\text { contratual formalmente apresentada }\end{array}$} & \multicolumn{2}{|c|}{ Estudo de Caso 2} \\
\hline$\Sigma(f o)$ & Posição & & Posição & $\Sigma(f o)$ \\
\hline 4.025 & $12^{\circ}$ & (1) Ambiente no canteiro de obra & $12^{\circ}$ & 5.043 \\
\hline 6.017 & $7^{\circ}$ & (2) Clareza do texto & $7^{\circ}$ & 5.537 \\
\hline 6.531 & $3^{\circ}$ & (3) Documentação de suporte & $4^{\circ}$ & 6.007 \\
\hline 6.392 & $5^{\circ}$ & (4) Domínio do projeto pelo Gerente da obra & $5^{\circ}$ & 5.985 \\
\hline 6.447 & $4^{\circ}$ & (5) Domínio do projeto pela equipe do Gerente da obra & $6^{\circ}$ & 5.931 \\
\hline 6.204 & $6^{\circ}$ & (6) Existência de registro dos fatos ocorridos & $3^{\circ}$ & 6.232 \\
\hline 6.933 & $1^{\circ}$ & (7) Fundamentação legal da reivindicação & $2^{\circ}$ & 6.251 \\
\hline 6.928 & $2^{\circ}$ & (8) Fundamentação técnica da reivindicação & $1^{\circ}$ & 6.326 \\
\hline 5.149 & $11^{\circ}$ & (9) Momento do projeto & $8^{\circ}$ & 5.498 \\
\hline 5.851 & $8^{\circ}$ & (10) Pontualidade no cumprimento do cronograma físico & $11^{\circ}$ & 5.076 \\
\hline 5.800 & $10^{\circ}$ & (11) Procedimento de decisão da outra parte & $10^{\circ}$ & 5.253 \\
\hline 5.789 & $9^{\circ}$ & (12) Qualidade da execução do projeto & $9^{\circ}$ & 5.285 \\
\hline 197 & $13^{\circ}$ & (13) Outros & $13^{\circ}$ & 644 \\
\hline 72.263 & & & & 69.068 \\
\hline
\end{tabular}

FONTE: $\quad$ Pesquisa realizada pelo autor.

LEGENDA: $\quad \Sigma(f o)=$ somatório das freqüências ajustadas das respostas às variáveis dos Quesitos 15 e 16 do Questionário.

OBSERVAÇÃO 1: No Estudo de Caso 1 obteve-se a mesma classificação para as variáveis (1), (2), (3), (4), (5), (6), (9), (10) e (13) dos Quesitos 15 e 16, tanto na apuração do Quesito 15 como na do Quesito 16 do questionário.

OBSERVAÇÃO 2: No Estudo de Caso 2 obteve-se a mesma classificação para as variáveis (2), (6), (7), (8), (9), (10), (12) e (13) dos Quesitos 15 e 16, tanto na apuração do Quesito 15 como na do Quesito 16 do questionário. 


\section{APÊNDICE D}

Teste de significância dos dados obtidos

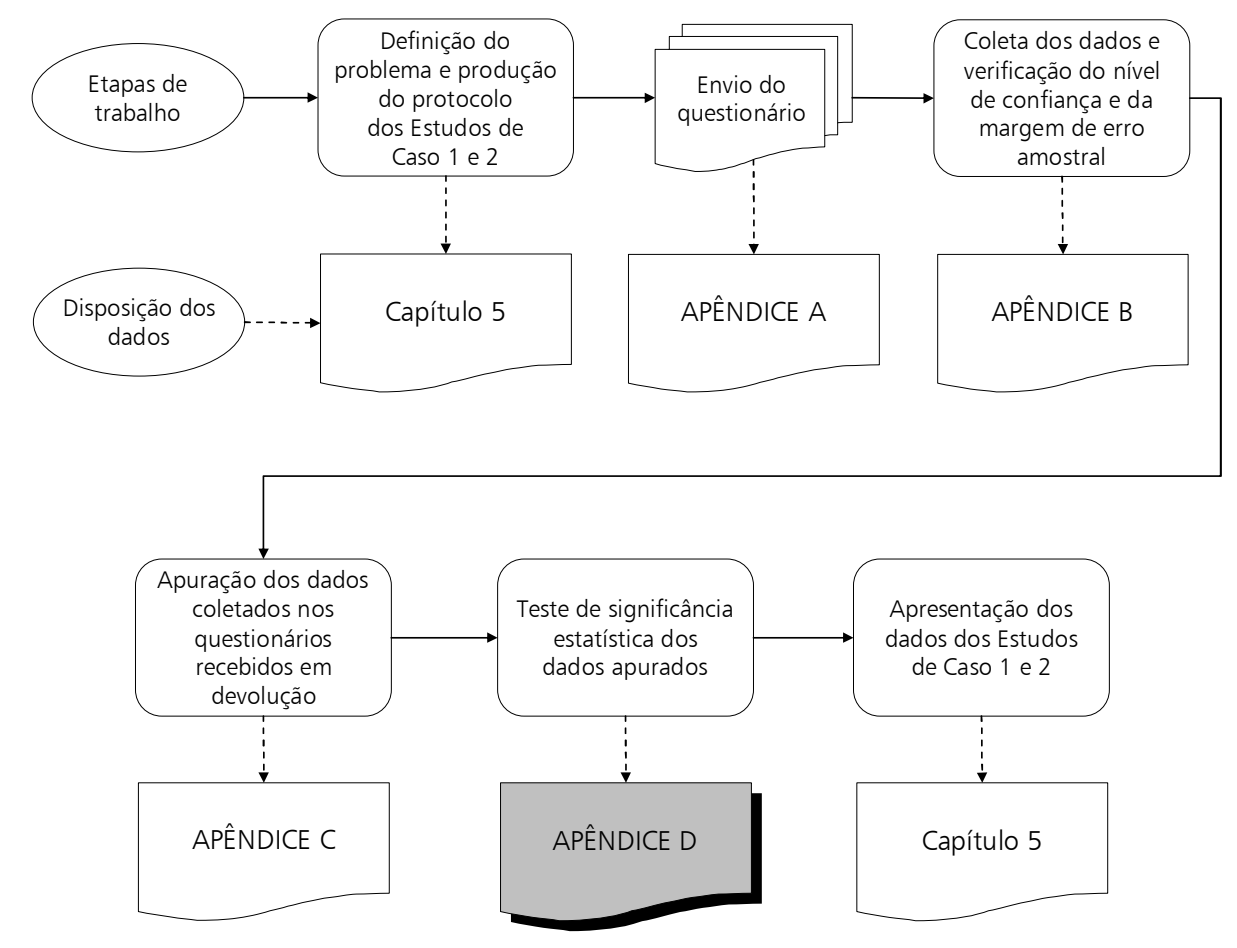


Este APÊNDICE D contém o teste de significância estatística dos dados provenientes dos Estudos de Caso 1 e 2, aplicado às variáveis dos Quesitos 7 a 16 do questionário, em cada Estudo de Caso. A significância estatística dos dados da pesquisa foi verificada por meio da aplicação do teste qui-quadrado.

Trata-se de teste de "grande importância na estimação estatística", segundo Downing e Clark (1998, p. 169), sendo usado neste trabalho para testar a aderência ou a homogeneidade dos dados das variáveis observadas.

O teste qui-quadrado preocupa-se essencialmente com as diferenças entre as freqüências obtidas da pesquisa por amostragem e as que poderiam ser esperadas caso não houvesse diferenças entre as categorias de variáveis. A suposição de que não há diferenças entre as categorias é conhecida como hipótese nula. Além disso, o teste quiquadrado procura identificar se as constatações observadas são verdadeiras ou resultam de um erro de amostragem. (REA e PARKER, 2000, p. 176, grifos dos autores).

Sendo $\chi$ a letra grega qui, a distribuição qui-quadrado é simbolizada por $\chi^{2}$, e mede as diferenças entre as freqüências esperadas das variáveis e as ajustadas, estas obtidas da pesquisa com base somente nas respostas válidas, excluídas as respostas inválidas ou ausentes. O cálculo é feito por intermédio da aplicação da seguinte expressão:

$$
\chi^{2}=\Sigma \frac{(f o-f e)^{2}}{f e}
$$

onde:

$\chi^{2}=$ distribuição qui-quadrado;

fo = freqüência observada e ajustada de cada variável;

$f e=$ freqüência esperada de cada variável, na suposição da inexistência de diferença.

FONTE: Rea e Parker (2000).

Equação D.1 - Cálculo da estatística qui-quadrado.

O procedimento de aplicação do teste e os conseqüentes resultados alcançados, são revelados nas Tabelas D.1 a D.10 deste APÊNDICE, as quais se articulam segundo mostra o Quadro D.1. 


\begin{tabular}{clcc}
\hline \multicolumn{1}{c}{ Quesitos do questionário } & $\begin{array}{c}\text { Estudo de } \\
\text { Caso 1 }\end{array}$ & $\begin{array}{c}\text { Estudo de } \\
\text { Caso 2 }\end{array}$ \\
\hline 7 e 8 & $\begin{array}{l}\text { Fatores que mais influem no Gerenciamento de } \\
\text { Projetos }\end{array}$ & Tabela D.1 & Tabela D.2 \\
\hline 11 e 10 & $\begin{array}{l}\text { Habilidades técnicas do Gerente que mais } \\
\text { influem no Gerenciamento de Projetos }\end{array}$ & $\begin{array}{l}\text { Habilidades pessoais do Gerente que mais } \\
\text { influem no Gerenciamento de Projetos }\end{array}$ & Tabela D.4 \\
\hline 13 e 14 & $\begin{array}{l}\text { Requisitos que mais influem na prática da } \\
\text { Administração de Contrato }\end{array}$ & Tabela D.5 & Tabela D.6 \\
\hline 15 e 16 & $\begin{array}{l}\text { Fatores que afetam o atendimento de reivin- } \\
\text { dicação contratual formalmente apresentada }\end{array}$ & Tabela D.9 & Tabela D.8 \\
\hline
\end{tabular}

Quadro D.1 - Articulação das Tabelas do APÊNDICE D.

Examinando-se as Tabelas apresentadas a seguir neste APÊNDICE, constata-se que as relações entre as variáveis dos Quesitos 7 e 8, 9 e 10, 11 e 12, 13 e 14, e 15 e 16 são estatisticamente significativas, nos níveis de confiança $95 \%$ e $99 \%$. 
Tabela D.1 - Teste dos dados relativos aos Quesitos 7 e 8 do EC-1.

\begin{tabular}{|c|c|c|c|c|c|}
\hline \multirow{2}{*}{$\begin{array}{l}\text { Fatores que mais influem no } \\
\text { Gerenciamento de Projetos }\end{array}$} & \multirow{2}{*}{$\begin{array}{l}\text { Fatores que mais influem no } \\
\text { Gerenciamento de Projetos }\end{array}$} & \multicolumn{2}{|c|}{ Quesito 7} & \multicolumn{2}{|c|}{ Quesito 8} \\
\hline & & fe & $(f o-f e)^{2} \div f e$ & fe & $(f o-f e)^{2} \div f e$ \\
\hline (1) & Abrangência do escopo & 711,4 & 28,89 & $5.731,6$ & 3,23 \\
\hline (2) & Acompanhamento e avaliação progressiva & 690,9 & 0,78 & $5.566,1$ & 0,05 \\
\hline (3) & Aquisição de materiais de construção & 508,2 & 50,82 & $4.094,8$ & 6,65 \\
\hline (4) & Avaliação estratégica da complexidade & 667,1 & 25,49 & $5.374,9$ & 2,84 \\
\hline (5) & Caminho crítico da gestão & 639,6 & 5,91 & $5.153,4$ & 0,59 \\
\hline (6) & Memória técnica da execução & 466,6 & 16,20 & $3.759,4$ & 2,21 \\
\hline (7) & Designação das pessoas da equipe & 699,3 & 2,90 & $5.633,7$ & 0,26 \\
\hline (8) & Detalhamento da estimativa & 632,0 & 0,65 & $5.092,0$ & 0,14 \\
\hline (9) & Estimativa de custo & 699,4 & 1,27 & $5.634,6$ & 0,09 \\
\hline (10) & Finalização do projeto & 584,5 & 40,38 & $4.709,5$ & 5,35 \\
\hline (11) & Gestão do custo & 661,5 & 0,03 & $5.329,5$ & 0,02 \\
\hline (12) & Organização do projeto & 794,0 & 28,40 & $6.397,0$ & 3,15 \\
\hline (13) & Planejamento do projeto & 838,6 & 70,51 & $6.756,4$ & 8,12 \\
\hline (14) & Produtividade da mão de obra de execução & 595,0 & 19,92 & $4.794,0$ & 2,72 \\
\hline$(15)$ & Produtividade na operação de equipamentos & 544,8 & 54,39 & $4.389,2$ & 7,12 \\
\hline (16) & Software para gerenciamento do projeto & 594,4 & 8,49 & $4.788,6$ & 1,22 \\
\hline \multirow[t]{2}{*}{ (17) } & \multirow[t]{2}{*}{ Outros } & 30,6 & 0,20 & 246,4 & 0,03 \\
\hline & & & 355,25 & & 43,77 \\
\hline \multicolumn{6}{|c|}{ Teste de significância do qui-quadrado } \\
\hline & \multicolumn{2}{|c|}{ Cálculo do qui-quadrado $\left(\chi^{2}\right)$ : } & \multicolumn{3}{|c|}{$\chi^{2}=\Sigma\left[(f o-f e)^{2} \div f e\right]=399,02$} \\
\hline & \multicolumn{2}{|c|}{ Níveis apropriados de confiança: } & \multicolumn{3}{|l|}{$95 \%$ ou $99 \%$} \\
\hline & \multicolumn{2}{|c|}{ Graus de liberdade $(g /)$ : } & \multicolumn{3}{|c|}{$g l=(r-1)(c-1)=16$} \\
\hline & \multicolumn{2}{|c|}{ Valor crítico da distribuição de qui-quadrado para $95 \%$ de confiança: } & \multicolumn{3}{|c|}{$26,296(<399,02)$} \\
\hline & \multicolumn{2}{|c|}{ Valor crítico da distribuição de qui-quadrado para $99 \%$ de confiança: } & \multicolumn{3}{|c|}{$32,000(<399,02)$} \\
\hline
\end{tabular}

FONTE: $\quad$ Pesquisa realizada pelo autor.

LEGENDA: $\quad f \circ=$ freqüência ajustada. $\quad f e=$ freqüência esperada.

$r=$ número de categorias da variável dependente (linha).

$c=$ número de categorias da variável independente (coluna).

OBSERVAÇÃO: Os valores críticos da distribuição de qui-quadrado, para os respectivos graus de liberdade e com 95\% e 99\% de confiança, foram extraídos de Rea \& Parker (2000, p. 179). 
Tabela D.2 - Teste dos dados relativos aos Quesitos 7 e 8 do EC-2.

\begin{tabular}{|c|c|c|c|c|c|}
\hline & \multirow{2}{*}{$\begin{array}{l}\text { Fatores que mais influem no } \\
\text { Gerenciamento de Projetos }\end{array}$} & \multicolumn{2}{|c|}{ Quesito 7} & \multicolumn{2}{|c|}{ Quesito 8} \\
\hline & & fe & $(f o-f e)^{2} \div f e$ & fe & $(f o-f e)^{2} \div f e$ \\
\hline (1) & Abrangência do escopo & 650,1 & 27,33 & $5.292,9$ & 3,19 \\
\hline (2) & Acompanhamento e avaliação progressiva & 596,7 & 0,04 & $4.858,3$ & 0,01 \\
\hline (3) & Aquisição de materiais de construção & 480,0 & 14,80 & $3.908,0$ & 1,92 \\
\hline (4) & Avaliação estratégica da complexidade & 652,5 & 25,86 & $5.312,5$ & 3,01 \\
\hline (5) & Caminho crítico da gestão & 604,5 & 3,01 & $4.921,5$ & 0,32 \\
\hline (6) & Memória técnica da execução & 408,8 & 71,83 & $3.328,2$ & 9,01 \\
\hline (7) & Designação das pessoas da equipe & 667,0 & 30,82 & $5.431,0$ & 3,60 \\
\hline (8) & Detalhamento da estimativa & 530,4 & 0,17 & $4.318,6$ & 0,03 \\
\hline (9) & Estimativa de custo & 589,3 & 2,69 & $4.797,7$ & 0,28 \\
\hline (10) & Finalização do projeto & 471,1 & 48,11 & $3.835,9$ & 6,08 \\
\hline (11) & Gestão do custo & 593,4 & 1,09 & $4.831,6$ & 0,17 \\
\hline (12) & Organização do projeto & 644,5 & 23,04 & $5.247,5$ & 2,67 \\
\hline (13) & Planejamento do projeto & 697,3 & 48,14 & $5.677,7$ & 5,67 \\
\hline (14) & Produtividade da mão de obra de execução & 526,7 & 8,49 & $4.288,3$ & 1,12 \\
\hline (15) & Produtividade na operação de equipamentos & 495,3 & 27,94 & $4.032,7$ & 3,57 \\
\hline (16) & Software para gerenciamento do projeto & 464,8 & 34,26 & $3.784,2$ & 4,35 \\
\hline (17) & Outros & 57,8 & 8,15 & 470,2 & 1,02 \\
\hline & & & 375,77 & & 46,04 \\
\hline & Teste & a do qui-qua & rado & & \\
\hline & Cálc & adrado $\left(\chi^{2}\right)$ : & $\chi^{2}=\Sigma[(f o-$ & $\div f e]=$ & 81 \\
\hline & Níveis & confiança: & $95 \%$ ou $99 \%$ & & \\
\hline & & erdade $(g l)$ : & $g l=(r-1)(c-$ & $=16$ & \\
\hline & Valor crítico da distribuição de qui-quadrac & confiança: & $26,296(<42$ & & \\
\hline & Valor crítico da distribuição de qui-quadrac & confiança: & $32,000(<42$ & & \\
\hline
\end{tabular}

FONTE: $\quad$ Pesquisa realizada pelo autor.

LEGENDA: $\quad f \circ=$ freqüência ajustada. $\quad f e=$ freqüência esperada.

$r=$ número de categorias da variável dependente (linha).

$c=$ número de categorias da variável independente (coluna).

OBSERVAÇÃO: Os valores críticos da distribuição de qui-quadrado, para os respectivos graus de liberdade e com 95\% e 99\% de confiança, foram extraídos de Rea \& Parker (2000, p. 179). 
Tabela D.3 - Teste dos dados relativos aos Quesitos 9 e 10 do EC-1.

\begin{tabular}{|c|c|c|c|c|c|}
\hline \multirow{2}{*}{\multicolumn{2}{|c|}{$\begin{array}{c}\text { Habilidades técnicas do gerente, que mais influem no } \\
\text { Gerenciamento de Projetos }\end{array}$}} & \multicolumn{2}{|c|}{ Quesito 9} & \multicolumn{2}{|c|}{ Quesito 10} \\
\hline & & fe & $(f o-f e)^{2} \div f e$ & fe & $(f o-f e)^{2} \div f e$ \\
\hline (1) & Administração simultânea de múltiplas prioridades & 701,3 & 29,68 & $5.791,7$ & 3,25 \\
\hline (2) & Ajuste do estilo de liderança ao longo da execução & 629,5 & 0,69 & $5.198,5$ & 0,14 \\
\hline (3) & Avaliação do empreendimento como um todo & 740,3 & 14,40 & $6.113,7$ & 1,51 \\
\hline (4) & Conceito das funções do processo de gestão & 634,4 & 1,36 & $5.239,6$ & 0,10 \\
\hline (5) & Conhecimento das próprias forças e fraquezas & 660,8 & 0,34 & $5.457,2$ & 0,01 \\
\hline (6) & Delegação & 728,6 & 22,13 & $6.017,4$ & 2,38 \\
\hline (7) & Desempenho (método de trabalho) do gerente & 726,3 & 18,30 & $5.997,7$ & 1,95 \\
\hline (8) & Desenvolvimento das pessoas & 689,1 & 0,17 & $5.690,9$ & 0,00 \\
\hline (9) & Escolha da melhor maneira de orçar & 516,0 & 39,85 & $4.261,0$ & 5,12 \\
\hline (10) & Estratégia & 715,1 & 15,51 & $5.905,9$ & 1,64 \\
\hline (11) & Integração da equipe & 768,4 & 35,67 & $6.345,6$ & 3,93 \\
\hline (12) & Liderança & 795,2 & 68,38 & $6.566,8$ & 7,71 \\
\hline (13) & Necessidades do Cliente & 612,2 & 7,31 & $5.055,8$ & 1,03 \\
\hline (14) & Procedimentos e políticas & 540,0 & 51,31 & $4.460,0$ & 6,55 \\
\hline (15) & Reuniões periódicas & 559,3 & 67,11 & $4.618,7$ & 8,50 \\
\hline (16) & Seleção e mobilização da equipe & 638,9 & 8,69 & $5.276,1$ & 1,22 \\
\hline (17) & Tática & 543,1 & 46,82 & $4.484,9$ & 5,99 \\
\hline \multirow[t]{2}{*}{ (18) } & Visão da oportunidade & 588,5 & 51,32 & $4.860,5$ & 6,56 \\
\hline & & & 479,05 & & 57,60 \\
\hline
\end{tabular}

Teste de significância do qui-quadrado

$$
\begin{aligned}
\text { Cálculo do qui-quadrado }\left(\chi^{2}\right): & \chi^{2}=\Sigma\left[(f o-f e)^{2} \div f e\right]=536,65 \\
\text { Níveis apropriados de confiança: } & 95 \% \text { ou } 99 \% \\
\text { Graus de liberdade }(g l): & g l=(r-1)(c-1)=17 \\
\text { Valor crítico da distribuição de qui-quadrado para 95\% de confiança: } & 27,587(<536,65)
\end{aligned}
$$$$
\text { Valor crítico da distribuição de qui-quadrado para 99\% de confiança: } \quad 33,409(<536,65)
$$

Resultado do teste: a relação entre as variáveis é estatisticamente significativa, nos níveis de confiança 95\% e 99\%.

$\begin{array}{ll}\text { FONTE: } & \text { Pesquisa realizada pelo autor. } \\ \text { LEGENDA: } & f o=\text { freqüência ajustada. } f e=\text { freqüência esperada. } \\ & r=\text { número de categorias da variável dependente (linha). } \\ & c=\text { número de categorias da variável independente (coluna). }\end{array}$

OBSERVAÇÃO: Os valores críticos da distribuição de qui-quadrado, para os respectivos graus de liberdade e com 95\% e $99 \%$ de confiança, foram extraídos de Rea \& Parker (2000, p. 179). 
Tabela D.4 - Teste dos dados relativos aos Quesitos 9 e 10 do EC-2.

\begin{tabular}{|c|c|c|c|c|c|}
\hline \multirow{2}{*}{\multicolumn{2}{|c|}{$\begin{array}{l}\text { Habilidades técnicas do Gerente, que mais influem no } \\
\text { Gerenciamento de Projetos }\end{array}$}} & \multicolumn{2}{|c|}{ Quesito 9} & \multicolumn{2}{|c|}{ Quesito 10} \\
\hline & & fe & $(f o-f e)^{2} \div f e$ & fe & $(f o-f e)^{2} \div f e$ \\
\hline (1) & Administração simultânea de múltiplas prioridades & 563,4 & 2,38 & $4.706,6$ & 0,22 \\
\hline (2) & Ajuste do estilo de liderança ao longo da execução & 525,3 & 10,37 & $4.388,7$ & 1,36 \\
\hline (3) & Avaliação do empreendimento como um todo & 653,2 & 22,94 & $5.456,8$ & 2,53 \\
\hline (4) & Conceito das funções do processo de gestão & 531,6 & 4,52 & $4.441,4$ & 0,62 \\
\hline (5) & Conhecimento das próprias forças e fraquezas & 593,6 & 4,82 & $4.959,4$ & 0,49 \\
\hline (6) & Delegação & 627,4 & 16,58 & $5.241,6$ & 1,80 \\
\hline (7) & Desempenho (método de trabalho) do gerente & 526,9 & 6,03 & $4.402,1$ & 0,82 \\
\hline (8) & Desenvolvimento das pessoas & 583,2 & 1,37 & $4.871,8$ & 0,22 \\
\hline (9) & Escolha da melhor maneira de orçar & 451,9 & 40,23 & $3.775,1$ & 5,02 \\
\hline (10) & Estratégia & 643,1 & 18,60 & $5.372,9$ & 2,03 \\
\hline (11) & Integração da equipe & 657,7 & 16,72 & $5.494,3$ & 1,82 \\
\hline (12) & Liderança & 695,9 & 59,83 & $5.814,1$ & 6,78 \\
\hline (13) & Necessidades do Cliente & 649,0 & 37,82 & $5.422,0$ & 4,24 \\
\hline (14) & Procedimentos e políticas & 473,8 & 36,03 & $3.958,2$ & 4,51 \\
\hline (15) & Reuniões periódicas & 404,1 & 120,30 & $3.375,9$ & 14,70 \\
\hline (16) & Seleção e mobilização da equipe & 582,1 & 0,49 & $4.862,9$ & 0,03 \\
\hline (17) & Tática & 489,7 & 46,31 & $4.091,3$ & 5,77 \\
\hline \multirow[t]{2}{*}{ (18) } & Visão da oportunidade & 568,1 & 1,41 & $4.745,9$ & 0,22 \\
\hline & & & 446,76 & & 53,18 \\
\hline
\end{tabular}

Teste de significância do qui-quadrado

Cálculo do qui-quadrado $\left(\chi^{2}\right): \quad \chi^{2}=\Sigma\left[(f o-f e)^{2} \div f e\right]=499,94$

Níveis apropriados de confiança: $\quad$ 95\% ou $99 \%$

Graus de liberdade $(g /): \quad g l=(r-1)(c-1)=17$

Valor crítico da distribuição de qui-quadrado para 95\% de confiança: $\quad$ 27,587 ( < 499,94 )

Valor crítico da distribuição de qui-quadrado para 99\% de confiança: $\quad 33,409(<499,94)$

Resultado do teste: a relação entre as variáveis é estatisticamente significativa, nos níveis de confiança 95\% e 99\%

FONTE: $\quad$ Pesquisa realizada pelo autor.

LEGENDA: $\quad f o=$ freqüência ajustada. $\quad f e=$ freqüência esperada.

$r=$ número de categorias da variável dependente (linha).

$c=$ número de categorias da variável independente (coluna).

OBSERVAÇÃO: Os valores críticos da distribuição de qui-quadrado, para os respectivos graus de liberdade e com $95 \%$ e $99 \%$ de confiança, foram extraídos de Rea \& Parker (2000, p. 179). 
Tabela D.5 - Teste dos dados relativos aos Quesitos 11 e 12 do EC-1.

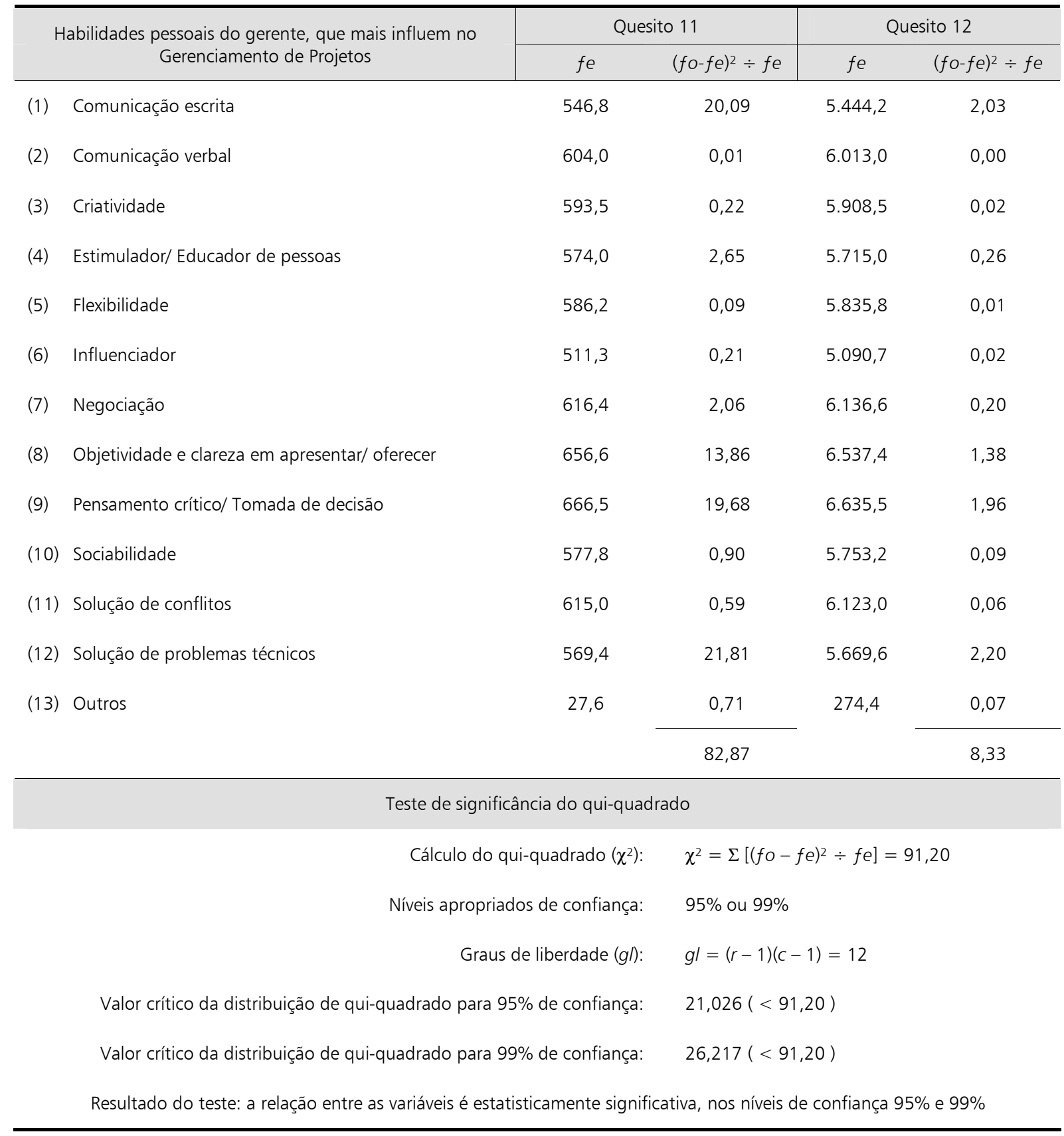

FONTE: $\quad$ Pesquisa realizada pelo autor.

LEGENDA: $\quad f o=$ freqüência ajustada. $f e=$ freqüência esperada.

$r=$ número de categorias da variável dependente (linha).

$c=$ número de categorias da variável independente (coluna).

OBSERVAÇÃO: Os valores críticos da distribuição de qui-quadrado, para os respectivos graus de liberdade e com 95\% e 99\% de confiança, foram extraídos de Rea \& Parker (2000, p. 179). 
Tabela D.6 - Teste dos dados relativos aos Quesitos 11 e 12 do EC-2.

\begin{tabular}{|c|c|c|c|c|c|}
\hline & \multirow{2}{*}{$\begin{array}{l}\text { Habilidades pessoais do Gerente, que mais influem no } \\
\text { Gerenciamento de Projetos }\end{array}$} & \multicolumn{2}{|c|}{ Quesito 11} & \multicolumn{2}{|c|}{ Quesito 12} \\
\hline & & fe & $(f o-f e)^{2} \div f e$ & fe & $(f o-f e)^{2} \div f e$ \\
\hline (1) & Comunicação escrita & 427,9 & 34,94 & $4.310,1$ & 3,56 \\
\hline (2) & Comunicação verbal & 501,5 & 0,00 & $5.051,5$ & 0,00 \\
\hline (3) & Criatividade & 533,0 & 6,57 & $5.369,0$ & 0,60 \\
\hline (4) & Estimulador/ Educador de pessoas & 553,6 & 14,53 & $5.576,4$ & 1,37 \\
\hline (5) & Flexibilidade & 521,0 & 0,28 & $5.248,0$ & 0,04 \\
\hline (6) & Influenciador & 532,1 & 8,71 & $5.359,9$ & 0,81 \\
\hline (7) & Negociação & 541,3 & 3,88 & $5.452,7$ & 0,35 \\
\hline (8) & Objetividade e clareza em apresentar/ oferecer & 536,9 & 5,90 & $5.408,1$ & 0,54 \\
\hline (9) & Pensamento crítico/ Tomada de decisão & 555,0 & 9,39 & $5.591,0$ & 0,87 \\
\hline (10) & Sociabilidade & 460,7 & 8,60 & $4.641,3$ & 0,90 \\
\hline (11) & Solução de conflitos & 498,5 & 3,14 & $5.021,5$ & 0,34 \\
\hline (12) & Solução de problemas técnicos & 421,1 & 45,58 & $4.241,9$ & 4,62 \\
\hline \multirow[t]{9}{*}{ (13) } & Outros & 53,6 & 0,37 & 539,4 & 0,04 \\
\hline & & & 141,91 & & 14,04 \\
\hline & \multicolumn{5}{|c|}{ Teste de significância do qui-quadrado } \\
\hline & \multicolumn{2}{|c|}{ Cálculo do qui-quadrado $\left(\chi^{2}\right)$ : } & \multicolumn{3}{|c|}{$\chi^{2}=\Sigma\left[(f o-f e)^{2} \div f e\right]=155,95$} \\
\hline & \multicolumn{2}{|c|}{ Níveis apropriados de confiança: } & $95 \%$ ou $99 \%$ & & \\
\hline & \multicolumn{2}{|c|}{ Graus de liberdade $(g l)$ : } & \multicolumn{2}{|c|}{$g l=(r-1)(c-1)=12$} & \\
\hline & \multicolumn{2}{|c|}{ Valor crítico da distribuição de qui-quadrado para $95 \%$ de confiança: } & \multicolumn{2}{|c|}{$21,026(<155,95)$} & \\
\hline & \multicolumn{2}{|c|}{ Valor crítico da distribuição de qui-quadrado para 99\% de confiança: } & \multicolumn{2}{|c|}{$26,217(<155,95)$} & \\
\hline & Resultado do teste: a relação entre as variáveis é esta & nte signific & iva, nos níveis d & onfiança $\subseteq$ s & e $99 \%$ \\
\hline
\end{tabular}

FONTE: $\quad$ Pesquisa realizada pelo autor.

LEGENDA: $\quad f o=$ freqüência ajustada. $f e=$ freqüência esperada.

$r=$ número de categorias da variável dependente (linha).

$c=$ número de categorias da variável independente (coluna).

OBSERVAÇÃO: Os valores críticos da distribuição de qui-quadrado, para os respectivos graus de liberdade e com 95\% e $99 \%$ de confiança, foram extraídos de Rea \& Parker (2000, p. 179). 
Tabela D.7 - Teste dos dados relativos aos Quesitos 13 e 14 do EC-1.

\begin{tabular}{|c|c|c|c|c|c|}
\hline & \multirow{2}{*}{$\begin{array}{l}\text { Requisitos que mais influem na prática da } \\
\text { Administração de Contrato }\end{array}$} & \multicolumn{2}{|c|}{ Quesito 13} & \multicolumn{2}{|c|}{ Quesito 14} \\
\hline & & fe & $(f o-f e)^{2} \div f e$ & fe & $(f o-f e)^{2} \div f e$ \\
\hline (1) & Apoio jurídico & 538,1 & 0,16 & $5.827,9$ & 0,02 \\
\hline (2) & Competência na negociação & 544,5 & 0,10 & $5.896,5$ & 0,01 \\
\hline (3) & Compreensão da base legal & 570,5 & 25,03 & $6.178,5$ & 2,23 \\
\hline (4) & Compreensão da base técnica & 586,7 & 14,54 & $6.353,3$ & 1,28 \\
\hline (5) & Conhecimento sobre o Cliente & 502,1 & 0,75 & $5.437,9$ & 0,08 \\
\hline (6) & Coordenação de interfaces & 528,5 & 0,16 & $5.723,5$ & 0,01 \\
\hline (7) & Documentação e arquivo & 529,5 & 5,88 & $5.734,5$ & 0,58 \\
\hline (8) & Domínio do escopo do contrato & 632,1 & 67,26 & $6.844,9$ & 6,07 \\
\hline (9) & Equipe qualificada & 581,3 & 16,44 & $6.294,7$ & 1,46 \\
\hline (10) & Integração de atividades multifuncionais & 509,1 & 2,60 & $5.512,9$ & 0,26 \\
\hline (11) & Liderança & 508,6 & 0,38 & $5.508,4$ & 0,04 \\
\hline (12) & Orçamento como conseqüência do planejamento & 500,0 & 22,66 & $5.415,0$ & 2,15 \\
\hline (13) & Postura ganha-ganha & 313,4 & 87,04 & $3.393,6$ & 8,12 \\
\hline \multirow[t]{2}{*}{ (14) } & Registro de fatos & 477,5 & 27,69 & $5.171,5$ & 2,62 \\
\hline & & & 270,69 & & 24,93 \\
\hline
\end{tabular}

Teste de significância do qui-quadrado

Cálculo do qui-quadrado $\left(\chi^{2}\right): \quad \chi^{2}=\Sigma\left[(f o-f e)^{2} \div f e\right]=295,62$

Níveis apropriados de confiança: $\quad 95 \%$ ou $99 \%$

Graus de liberdade $(g /): \quad g l=(r-1)(c-1)=13$

Valor crítico da distribuição de qui-quadrado para 95\% de confiança: $\quad 22,362(<295,62)$

Valor crítico da distribuição de qui-quadrado para 99\% de confiança: $\quad 27,688(<295,62)$

Resultado do teste: a relação entre as variáveis é estatisticamente significativa, nos níveis de confiança 95\% e 99\%

FONTE: $\quad$ Pesquisa elaborada pelo autor.

LEGENDA: $\quad f o=$ freqüência ajustada. $\quad f e=$ freqüência esperada.

$r=$ número de categorias da variável dependente (linha).

$c=$ número de categorias da variável independente (coluna).

OBSERVAÇÃO: Os valores críticos da distribuição de qui-quadrado, para os respectivos graus de liberdade e com 95\% e $99 \%$ de confiança, foram extraídos de Rea \& Parker (2000, p. 179). 
Tabela D.8 - Teste dos dados relativos aos Quesitos 13 e 14 do EC-2.

\begin{tabular}{|c|c|c|c|c|c|}
\hline & \multirow{2}{*}{$\begin{array}{l}\text { Requisitos que mais influem na prática da } \\
\text { Administração de Contrato }\end{array}$} & \multicolumn{2}{|c|}{ Quesito 13} & \multicolumn{2}{|c|}{ Quesito 14} \\
\hline & & fe & $(f o-f e)^{2} \div f e$ & fe & $(f o-f e)^{2} \div f e$ \\
\hline (1) & Apoio jurídico & 433,3 & 24,14 & $4.852,7$ & 2,17 \\
\hline (2) & Competência na negociação & 495,0 & 6,57 & $5.544,0$ & 0,58 \\
\hline (3) & Compreensão da base legal & 472,2 & 1,10 & $5.288,8$ & 0,10 \\
\hline (4) & Compreensão da base técnica & 461,1 & 0,01 & $5.163,9$ & 0,00 \\
\hline (5) & Conhecimento sobre o Cliente & 514,9 & 49,77 & $5.767,1$ & 4,43 \\
\hline (6) & Coordenação de interfaces & 433,4 & 2,58 & $4.854,6$ & 0,23 \\
\hline (7) & Documentação e arquivo & 403,6 & 40,98 & $4.520,4$ & 3,67 \\
\hline (8) & Domínio do escopo do contrato & 532,7 & 79,90 & $5.966,3$ & 7,11 \\
\hline (9) & Equipe qualificada & 482,6 & 6,82 & $5.405,4$ & 0,60 \\
\hline (10) & Integração de atividades multifuncionais & 402,6 & 26,67 & $4.509,4$ & 2,39 \\
\hline (11) & Liderança & 483,8 & 1,77 & $5.418,2$ & 0,15 \\
\hline$(12)$ & Orçamento como conseqüência do planejamento & 436,6 & 11,11 & $4.890,4$ & 1,00 \\
\hline (13) & Postura ganha-ganha & 404,3 & 2,28 & $4.528,7$ & 0,21 \\
\hline \multirow[t]{2}{*}{ (14) } & Registro de fatos & 448,8 & 8,80 & $5.027,2$ & 0,79 \\
\hline & & & 262,48 & & 23,44 \\
\hline
\end{tabular}

Teste de significância do qui-quadrado

Cálculo do qui-quadrado $\left(\chi^{2}\right): \quad \chi^{2}=\Sigma\left[(f o-f e)^{2} \div f e\right]=285,92$

Níveis apropriados de confiança: $\quad 95 \%$ ou $99 \%$

Graus de liberdade $(g l): \quad g l=(r-1)(c-1)=13$

Valor crítico da distribuição de qui-quadrado para 95\% de confiança: $\quad 22,362(<285,92)$

Valor crítico da distribuição de qui-quadrado para 99\% de confiança: $\quad$ 27,688 ( < 285,92 )

Resultado do teste: a relação entre as variáveis é estatisticamente significativa, nos níveis de confiança 95\% e 99\%

FONTE: $\quad$ Pesquisa realizada pelo autor.

LEGENDA: $\quad f o=$ freqüência ajustada. $\quad f e=$ freqüência esperada.

$r=$ número de categorias da variável dependente (linha).

$c=$ número de categorias da variável independente (coluna).

OBSERVAÇÃO: $\quad$ Os valores críticos da distribuição de qui-quadrado, para os respectivos graus de liberdade e com 95\% e 99\% de confiança, foram extraídos de Rea \& Parker (2000, p. 179). 
Tabela D.9 - Teste dos dados relativos aos Quesitos 15 e 16 do EC-1.

\begin{tabular}{|c|c|c|c|c|c|}
\hline & \multirow{2}{*}{$\begin{array}{l}\text { Fatores que afetam o atendimento de reivindicação } \\
\text { contratual formalmente apresentada }\end{array}$} & \multicolumn{2}{|c|}{ Quesito 15} & \multicolumn{2}{|c|}{ Quesito 16} \\
\hline & & fe & $(f o-f e)^{2} \div f e$ & fe & $(f o-f e)^{2} \div f e$ \\
\hline (1) & Ambiente no canteiro de obra & 384,8 & 25,11 & $3.640,2$ & 2,86 \\
\hline (2) & Clareza do texto & 575,3 & 0,11 & $5.441,7$ & 0,00 \\
\hline (3) & Documentação de suporte & 624,4 & 1,26 & $5.906,6$ & 0,08 \\
\hline (4) & Domínio do projeto por parte do Gerente da obra & 611,1 & 2,04 & $5.780,9$ & 0,14 \\
\hline (5) & Domínio do projeto pela equipe do Gerente da obra & 616,4 & 2,11 & $5.830,6$ & 0,15 \\
\hline (6) & Existência de registro dos fatos ocorridos & 593,2 & 0,14 & $5.610,8$ & 0,00 \\
\hline (7) & Fundamentação legal da reivindicação & 662,9 & 13,10 & $6.270,1$ & 1,16 \\
\hline (8) & Fundamentação técnica da reivindicação & 662,4 & 6,28 & $6.265,6$ & 0,52 \\
\hline (9) & Momento do projeto & 492,3 & 1,35 & $4.656,7$ & 0,21 \\
\hline (10) & Pontualidade no cumprimento do cronograma físico & 559,4 & 1,26 & $5.291,6$ & 0,20 \\
\hline (11) & Procedimento de decisão da outra parte & 554,5 & 6,91 & $5.245,5$ & 0,87 \\
\hline (12) & Qualidade da execução do projeto & 553,5 & 0,93 & $5.235,5$ & 0,16 \\
\hline \multirow[t]{2}{*}{ (13) } & \multirow[t]{2}{*}{ Outros } & 18,8 & 0,16 & 178,2 & 0,02 \\
\hline & & & 60,76 & & 6,36 \\
\hline \multicolumn{6}{|c|}{ Teste de significância do qui-quadrado } \\
\hline & \multicolumn{2}{|c|}{ Cálculo do qui-quadrado $\left(\chi^{2}\right)$ : } & \multicolumn{3}{|c|}{$\chi^{2}=\Sigma\left[(f o-f e)^{2} \div f e\right]=67,12$} \\
\hline & \multicolumn{2}{|c|}{ Níveis apropriados de confiança: } & \multicolumn{3}{|l|}{$95 \%$ ou $99 \%$} \\
\hline & \multicolumn{2}{|c|}{ Graus de liberdade $(g l)$ : } & \multicolumn{3}{|c|}{$g l=(r-1)(c-1)=12$} \\
\hline & \multicolumn{2}{|c|}{ Valor crítico da distribuição de qui-quadrado para $95 \%$ de confiança: } & \multicolumn{3}{|c|}{$21,026(<67,12)$} \\
\hline & \multicolumn{2}{|c|}{ Valor crítico da distribuição de qui-quadrado para $99 \%$ de confiança: } & \multicolumn{3}{|c|}{$26,217(<67,12)$} \\
\hline & \multicolumn{5}{|c|}{ Resultado do teste: a relação entre as variáveis é estatisticamente significativa, nos níveis de confiança 95\% e 99\% } \\
\hline
\end{tabular}

FONTE: $\quad$ Pesquisa realizada pelo autor.

LEGENDA: $\quad f o=$ freqüência ajustada. $f e=$ freqüência esperada.

$r=$ número de categorias da variável dependente (linha).

$c=$ número de categorias da variável independente (coluna).

OBSERVAÇÃO: Os valores críticos da distribuição de qui-quadrado, para os respectivos graus de liberdade e com 95\% e $99 \%$ de confiança, foram extraídos de Rea \& Parker (2000, p. 179). 
Tabela D.10 - Teste dos dados relativos aos Quesitos 15 e 16 do EC-2.

\begin{tabular}{|c|c|c|c|c|c|}
\hline & \multirow{2}{*}{$\begin{array}{l}\text { Fatores que afetam o atendimento de reivindicação } \\
\text { contratual formalmente apresentada }\end{array}$} & \multicolumn{2}{|c|}{ Quesito 15} & \multicolumn{2}{|c|}{ Quesito 16} \\
\hline & & fe & $(f o-f e)^{2} \div f e$ & fe & $(f o-f e)^{2} \div f e$ \\
\hline (1) & Ambiente no canteiro de obra & 455,9 & 7,10 & $4.587,1$ & 0,71 \\
\hline (2) & Clareza do texto & 500,6 & 1,87 & $5.036,4$ & 0,19 \\
\hline (3) & Documentação de suporte & 543,1 & 1,24 & $5.463,9$ & 0,12 \\
\hline (4) & Domínio do projeto por parte do Gerente da obra & 541,1 & 4,07 & $5.443,9$ & 0,40 \\
\hline (5) & Domínio do projeto pela equipe do Gerente da obra & 536,2 & 3,91 & $5.394,8$ & 0,38 \\
\hline (6) & Existência de registro dos fatos ocorridos & 563,4 & 6,74 & $5.668,6$ & 0,66 \\
\hline (7) & Fundamentação legal da reivindicação & 565,1 & 7,92 & $5.685,9$ & 0,78 \\
\hline (8) & Fundamentação técnica da reivindicação & 571,9 & 13,57 & $5.754,1$ & 1,34 \\
\hline (9) & Momento do projeto & 497,0 & 3,23 & $5.001,0$ & 0,32 \\
\hline (10) & Pontualidade no cumprimento do cronograma físico & 458,9 & 8,89 & $4.617,1$ & 0,89 \\
\hline (11) & Procedimento de decisão da outra parte & 474,9 & 15,90 & $4.778,1$ & 1,59 \\
\hline (12) & Qualidade da execução do projeto & 477,8 & 8,78 & $4.807,2$ & 0,88 \\
\hline \multirow[t]{8}{*}{ (13) } & \multirow[t]{2}{*}{ Outros } & 58,2 & 1,04 & 585,8 & 0,10 \\
\hline & & & 84,26 & & 8,38 \\
\hline & \multicolumn{5}{|c|}{ Teste de significância do qui-quadrado } \\
\hline & \multicolumn{2}{|c|}{ Cálculo do qui-quadrado $\left(\chi^{2}\right)$ : } & \multicolumn{3}{|c|}{$\chi^{2}=\Sigma\left[(f o-f e)^{2} \div f e\right]=92,64$} \\
\hline & \multicolumn{2}{|c|}{ Níveis apropriados de confiança: } & \multicolumn{3}{|l|}{$95 \%$ ou $99 \%$} \\
\hline & \multicolumn{2}{|c|}{ Graus de liberdade $(g /)$ : } & \multicolumn{3}{|c|}{$g l=(r-1)(c-1)=12$} \\
\hline & \multicolumn{2}{|c|}{ Valor crítico da distribuição de qui-quadrado para $95 \%$ de confiança: } & \multicolumn{3}{|c|}{$21,026(<92,64)$} \\
\hline & \multicolumn{2}{|c|}{ Valor crítico da distribuição de qui-quadrado para $99 \%$ de confiança: } & \multicolumn{3}{|c|}{$26,217(<92,64)$} \\
\hline
\end{tabular}

FONTE: $\quad$ Pesquisa realizada pelo autor.

LEGENDA: $\quad f o=$ freqüência ajustada. $f e=$ freqüência esperada.

$r=$ número de categorias da variável dependente (linha).

$c=$ número de categorias da variável independente (coluna).

OBSERVAÇÃO: Os valores críticos da distribuição de qui-quadrado, para os respectivos graus de liberdade e com 95\% e $99 \%$ de confiança, foram extraídos de Rea \& Parker (2000, p. 179). 


\section{APÊNDICE E}

Referencial jurídico para orientar a ação do gerente 
Este APÊNDICE E reproduz, na íntegra, a entrevista concedida com exclusividade ao autor da dissertação, em fins de novembro de 2006, pelo advogado ANTÔNIO CARLOS CINTRA DO AMARAL, Mestre em Direito e Professor no Curso de Especialização em Direito Administrativo (pós-graduação lato sensu) na Pontifícia Universidade Católica de São Paulo - PUC/SP.

O entrevistado é jurisconsulto, especialista em Direito Administrativo e Econômico, sobretudo nas áreas de licitações, contratos e concessões de serviço público. Desde 1982, é o diretor e coordenador-geral do Centro de Estudos sobre Licitações e Contratos - CELC, em São Paulo, em cujo escritório a entrevista teve lugar. Foi Professor de Direito Econômico na Faculdade de Direito da PUC/SP, Professor-Assistente de Sociologia na Faculdade de Filosofia da Universidade Federal de Pernambuco e Consultor Jurídico do Estado de Pernambuco.

Autor dos livros: Extinção do Ato Administrativo (São Paulo: Revista dos Tribunais, 1978); Licitações nas Empresas Estatais (São Paulo: McGraw Hill do Brasil, 1979); Licitação para Concessão de Serviço Público (São Paulo: Malheiros, 1995); Ato Administrativo, Licitações e Contrato Administrativo (1. ed., 2. tir. São Paulo: Malheiros, 1996); Comentando as Licitações Públicas (Rio de Janeiro: Temas \& Idéias, 2002); Concessão de Serviço Público (2. ed., ver., atual. e ampl. São Paulo: Malheiros, 2002. 1 ed., 1996); e Licitação e Contrato Administrativo: Estudos, Pareceres e Comentários (Belo Horizonte: Fórum, 2006). Autor de diversos estudos, artigos e pareceres publicados em revistas jurídicas brasileiras, e de Comentários divulgados quinzenalmente no site <www.celc.com.br>, desde outubro de 1999.

\section{RR. Quais as distinções básicas entre os contratos de direito privado e os contratos administrativos?}

ACCA. Os contratos atribuem direitos e obrigações às partes que os celebram. Suas cláusulas devem ser observadas e cumpridas. O princípio básico dos contratos em geral é o "pacta sunt servanda", ou seja, os pactos devem ser cumpridos.

Eles têm a função de realizar interesses específicos das partes. Daí decorre uma distinção importante entre contratos celebrados por pessoas privadas e contratos administrativos. Aqueles têm por função realizar interesses privados, situados no mesmo plano, enquanto estes têm por função realizar o interesse público, que se sobrepõe ao interesse privado da contratada. 
As partes no contrato de direito privado podem, durante sua execução, livremente alterar o que ajustaram, desde que haja consenso e as novas regras contratuais - assim como as regras originais - não sejam proibidas por lei. Nos contratos administrativos, a Administração pode alterar unilateralmente as regras pactuadas, desde que para tal tenha amparo na legislação aplicável (Constituição e legislação administrativa, especialmente a Lei 8.666/93) e vise à satisfação do interesse público. Esta é uma exceção ao princípio "pacta sunt servanda", observando-se que, nessa hipótese, a contratada tem direito ao "equivalente econômico". Ou seja: nos contratos administrativos, a contratada não tem direito à imutabilidade do contrato, mas sim ao respeito à equação econômica inicial.

Nos contratos de direito privado, as partes podem pactuar ou repactuar o que não seja proibido por lei, enquanto nos contratos administrativos a Administração somente pode pactuar ou repactuar o que é autorizado por lei. No primeiro caso, vale o princípio de que o que não é proibido é permitido. No segundo, o de que o que não é permitido é proibido.

RR. Como o Gerente de Projeto deve se portar na gestão dos contratos de direito privado e na dos contratos administrativos?

ACCA. Há que distinguir, a meu ver, a gestão do contrato e a gestão do empreendimento. São duas funções distintas, se bem que possam ser exercidas pelo mesmo gestor. Não vejo diferença substancial entre a gestão de um contrato de direito privado e a de um contrato administrativo, salvo a de que eles se submetem a regimes jurídicos diversos, um ao Código Civil, o outro à Constituição, à legislação administrativa (especialmente à Lei 8.666/93) e apenas supletivamente ao Código Civil.

A gestão do contrato é uma atividade necessariamente multidisciplinar. Está sujeita a controles, tanto nos contratos de direito privado, quanto nos contratos administrativos. Nos primeiros, o controle é dos sócios ou acionistas, exercido com o auxílio de auditorias internas ou externas. Nos contratos administrativos, o controle externo é dos tribunais de contas, do Ministério Público, do Judiciário e sobretudo, por se tratar de aplicação de dinheiro público, da sociedade e da mídia. 
O gestor, porém, não é um órgão de controle. A ele cabe diligenciar no sentido de que as obrigações contratuais sejam cumpridas, tanto pela contratante quanto pela contratada. Sem esquecer, porém, que seus atos são suscetíveis de questionamento pelos órgãos de controle.

Neste ponto, penso que costuma haver uma distorção na atividade de muitos gestores de contratos. O gestor da contratante costuma ver sua função como sendo a de cobrar o cumprimento das obrigações pela contratada. E vice-versa. Não se apercebem de que aos dois gestores cabe, igualmente, buscar a eficácia da contratação, o que somente se consegue mediante o cumprimento das obrigações das duas (ou mais) partes.

\section{RR. Quais as causas do desequilíbrio econômico-financeiro de um contrato e os pressupostos para seu reequilíbrio?}

ACCA. O desequilíbrio pode ser provocado por fatores internos ou externos ao contrato.

Os fatores internos são aqueles atribuíveis à contratante, tais como alteração de projeto e atraso na liberação de áreas, prevista no contrato.

Os fatores externos abrangem:

a) fato do príncipe, que é toda atuação estatal que repercute indiretamente no contrato, tais como aumento e redução de tributos, alteração de política cambial ou de política ambiental e intervenção nos preços (planos econômicos); e

b) os fatos incluídos na teoria da imprevisão, tais como surto inflacionário, sujeições imprevistas, força maior (greve abusiva, incêndio provocado por terceiros) e caso fortuito (chuvas inesperadas, índice pluviométrico anormal).

Para que surja o direito ao reequilíbrio do contrato (e correspondente dever da outra parte de reequilibrar o contrato) é necessário que o fato que provocou o desequilíbrio tenha sido imprevisível (ou previsível mas de conseqüências incalculáveis) e se contenha na álea extraordinária do negócio.

Não existe critério objetivo para distinguir álea ordinária e álea extraordinária. A 
questão deve ser analisada caso a caso.

Assim, tanto nos contratos de direito privado, quanto nos contratos administrativos, ocorrido o desequilíbrio econômico-financeiro por fato superveniente e imprevisível contido na "álea ou risco extraordinário", deve proceder-se a seu reequilíbrio. O que difere é o fundamento jurídico-conceitual invocado. Nos contratos administrativos, a teoria da imprevisão. Nos contratos de direito privado, a teoria da base do negócio.

Há, porém, uma relevante distinção teórica, de conseqüências práticas. Nos contratos de direito privado, é necessário que a onerosidade seja "excessiva", de acordo com o Código Civil (art. 478). Nos contratos administrativos, essa excessividade não é exigida, já que a Constituição determina que sejam mantidas as condições iniciais da proposta (art. 37, XXI).

O conceito de "onerosidade excessiva" deve ser determinado em cada caso concreto e essa determinação tem um alto grau de subjetividade. Assim como ocorre com o conceito de "álea ou risco extraordinário".

Por último: o reequilíbrio é uma via de duas mãos. Se em regra o desequilíbrio ocorre em desfavor da contratada, há casos em que ocorre em desfavor da contratante. O dever de reequilibrar o contrato existe em ambas as hipóteses.

\section{RR. Toda alteração contratual deve ser formalizada?}

ACCA. Toda alteração contratual deve ser formalizada por um aditivo. Nos contratos de direito privado, esse aditivo pode ser uma simples ata, um registro no diário de obras, ou uma troca de correspondências. Nos contratos administrativos, a alteração deve ser formalizada mediante instrumento próprio.

Nos contratos administrativos, é comum alegar-se que a alteração de quantitativos pode ensejar o chamado "jogo de planilha". Mas não se podem estabelecer regras de administração de contratos a partir de situações patológicas. Seria irrealismo esperar que um projeto básico, por mais bem elaborado que seja, contemple com exatidão os 
quantitativos estimados para cada item da planilha. Ainda que a licitação seja precedida de um excelente projeto executivo, não se obtém a desejável mas inalcançável precisão absoluta. Isso somente é possível quando da elaboração do projeto concluído (as built).

Nesse sentido, estava correta a Norma NBR-5670/77 da ABNT, datada de 1977, quando definia projeto básico como "Projeto que reúne os elementos, discriminações técnicas necessárias e suficientes à contratação da execução do mesmo", enquanto projeto executivo era o "Projeto que reúne os elementos necessários e suficientes à execução completa do mesmo", e projeto concluído ("as built") era a "Definição qualitativa e quantitativa de todos os serviços executados, resultante do projeto executivo com as alterações e modificações havidas durante a execução".

A inevitável imprecisão do projeto básico nas contratações administrativas é admitida na alínea "b" do inciso I do art. 65 da Lei 8.666/93, quando prevê a necessidade de acréscimo ou diminuição quantitativa do objeto do contrato.

Todo e qualquer acréscimo do valor contratual deve ser solidamente justificado, mesmo que mínimo. Na prática, costuma-se entender que o limite de $25 \%$, estabelecido nos $\iint 1^{\circ}$ e $2^{\circ}$ do art. 65 da Lei 8.666/93 para os contratos administrativos, é uma espécie de "crédito automático". Vale dizer: é como se a Administração estivesse autorizada a proceder a extensões contratuais até aquele limite, independentemente de motivação. Esta talvez seja uma das razões que levam a Administração a deparar-se, ao final da execução da obra ou empreendimento, com a incômoda situação de ter que ultrapassar o limite legal para evitar o mal maior de ter que rescindir o contrato.

Note-se que há uma aparente contradição entre o art. $3^{\circ}$, alínea "f", da Resolução no 361/91 da CONFEA, que diz ser uma das características principais do projeto básico "definir as quantidades e os custos de serviços e fornecimentos com precisão compativel com o tipo e porte da obra, de tal forma a ensejar a determinação do custo global da obra com precisão de mais ou menos $15 \%$ (quinze por cento)", e as normas dos $\iint 1^{\circ}$ e $2^{\circ}$ do art. 65 da Lei 8.666/93. A norma do CONFEA - que reforça o entendimento acima de que não existe precisão absoluta na estimativa de quantidades pelo projeto básico - tem como destinatários os projetistas, e vale para todos os contratos, de direito privado ou administrativos. $\mathrm{O}$ 
CONFEA admite uma margem de imprecisão de 15\%. Um bom projeto básico é o que se contém nessa margem de imprecisão. Em relação aos contratos administrativos, a lei admite extensões contratuais, inclusive decorrentes de alterações de projeto, até $25 \%$, calculados sobre o valor global estimado, e não sobre o valor estimado de cada item da planilha. Trata-se de norma que tem por destinatários os agentes administrativos.

Volto ao "jogo de planilha". O TCU tem entendido que na hipótese de aumentos ou reduções significativas de quantidades a Administração deve renegociar os respectivos preços, com vista a reduzi-los ou aumentá-los, conforme o caso. Isso em função da economia de escala.

Vale mencionar duas decisões do TCU sobre o assunto.

No Acórdão no 1.684/2003 - Plenário, o Relator, Ministro Marcos Vinicios Vilaça, mencionou o fato de que a empresa vencedora da licitação elaborou proposta em que subavaliou os preços unitários dos serviços com utilização de motoscraper e superavaliou os preços unitários dos serviços de caminhão. Posteriormente, os contratantes substituíram o motoscraper por caminhão. Em casos como este, disse o Ministro-Relator, é indispensável que os preços sejam renegociados, "para que se mantenha o equilíbrio original" (itens 11 a 24 do Voto do Relator).

Já na Decisão no 1.028/2001 - Plenário, o Ministro Relator, Ubiratan Aguiar, sustentou, em seu Voto, que deveria haver uma "compensação" entre os itens que apresentavam valores superavaliados e aqueles que consignavam preços subavaliados. Afirmou ele: "Pretender-se, portanto, redu₹ir os preços inicialmente contratados daqueles itens que se encontravam superavaliados, sem alterar-se aqueles que se encontravam subavaliados, implicaria em eliminar-se a 'compensação' inicialmente existente, com a conseqüente alteração do equilíbrio econômico-financeiro dos contratos".

Vale acentuar que dois princípios vêm ganhando cada vez maior espaço no direito administrativo: o da razoabilidade e o da economicidade. O primeiro corresponde à lógica do razoável, exposta sobretudo pelo jurista belga Chaïm Perelman. São vários os ensaios de Perelman sobre esse tema, reunidos em livro publicado em 
Bruxelas em 1990 e traduzido para o português e publicado no Brasil pela Martins Fontes ("Ética e Direito", São Paulo, 1996). O segundo, inscrito no art. 70 da Constituição Federal, traduz, no campo do direito, a relação custo-benefício.

Sobre a acolhida do princípio da economicidade pelo TCU, veja-se "O Princípio Constitucional da Economicidade na Jurisprudência do Tribunal de Contas da União", de autoria do Subprocurador-Geral do Ministério Público junto àquela Corte de Contas, Paulo Soares Bugarin (Belo Horizonte, Editora Fórum, 2004). Escreve Bugarin que tanto a doutrina quanto a jurisprudência do TCU reconhecem " $a$ 'umbilical' relação entre os principios da economicidade e razoabilidade (proporcionalidade)" (p. 216) e que a economicidade se põe em dois planos materiais: no primeiro, "acolheria a idéia do máximo resultado possível" e, no segundo, "se fixa mais no aspecto menor custo possível, dado um resultado já definido que se visa a alcançar" (p. 212).

RR. O que é indispensável ao atendimento, pela contratante, de reivindicação que lhe tenha sido formalmente apresentada pela contratada?

ACCA. Uma reivindicação de reequilíbrio econômico-financeiro deve ser acompanhada de sólida fundamentação jurídica, e estar bem demonstrada e quantificada. Na prática, é comum encontrarmos pleitos de reequilíbrio referentes a contratos que já nasceram desequilibrados, quer em decorrência de erro na formação do preço proposto, quer - o que é pior - de “mergulho”. Nesses casos, a reivindicação é insustentável, já que o pleito objetiva não o reequilíbrio do contrato, mas o equilíbrio que lhe faltou na formação do vínculo contratual.

\section{RR. Há algo que queira acrescentar?}

ACCA. Em meu livro "Licitação e Contrato Administrativo - Estudos, Pareceres e Comentários", publicado em 2006 pela Editora Fórum, de Belo Horizonte, há um capítulo com o título "Gestão de Contratos de Obras e Serviços" (pp. 213/228). Gostaria de terminar transcrevendo dois trechos desse trabalho. 
Escrevi à página 221:

"Quaisquer alterações têm que ser procedidas com o devido cuidado, especialmente:

a) não se pode desfigurar o contrato, executando-se algo que não se inclua no objeto contratual;

b) as extensões contratuais devem ser solidamente justificadas, independentemente de seu valor;

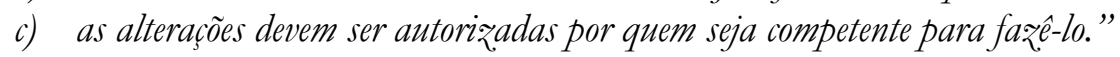

Acrescentei logo a seguir (pp. 221/222):

"Outro aspecto importante na gestão do contrato é o controle do cumprimento das obrigacões contratuais. Esse controle deve, inclusive, estender-se aos subcontratos.

O gestor do contrato é responsável pela consecução dos objetivos que nortearam a contratação. Disso resulta que:

a) deve ele não apenas articular-se com o pessoal da outra parte, mas também articular as áreas internas envolvidas no contrato;

b) as áreas internas envolvidas devem prestar-lhe todo o apoio administrativo, técnico e jurídico que lhes seja solicitado.

A articulação interna deve ser efetuada, sempre que possivel, informalmente. Esclarecimentos devem ser solicitados, em regra, verbalmente, e também verbalmente prestados. Há que presidir, nesses entendimentos, a confiança mútua. Ninguém tem o direito de pedir ou prestar esclarecimentos com o objetivo de embaraçar seu interlocutor. A boa execução do contrato é um benefício para ambas as partes e somente pode ser obtida com uma adequada gestão, dependente não só da boa coordenação pelo seu principal responsável, como também da qualidade e presteza do apoio administrativo, comercial, técnico e jurídico que lhe seja prestado.

O gestor do contrato, porém, deve aparelhar-se, tanto quanto possivel, para reduzir as dúvidas e, portanto, o numero de oportunidades em que precise recorrer às demais áreas. A capacidade de decisão própria, sem necessidade de informações, esclarecimentos ou pareceres, tem que ser desenvolvida ao máximo. A par disso, é necessário discernir ainda, e muito bem, quando é necessário recorrer a uma dessas áreas, em busca de respaldo a uma decisão, e quando a decisão pode e deve ser tomada de imediato, sem consulta. As duas preocupações estão interligadas e se reduzem a uma única: aperfeiçoamento profissional.

Já a articulação externa deve, em regra, ser tradurida em documentos escritos, especialmente quando o contrato ou a lei assim o prevejam expressamente." 